RB 119

Glasgow

qniversity Iibraty
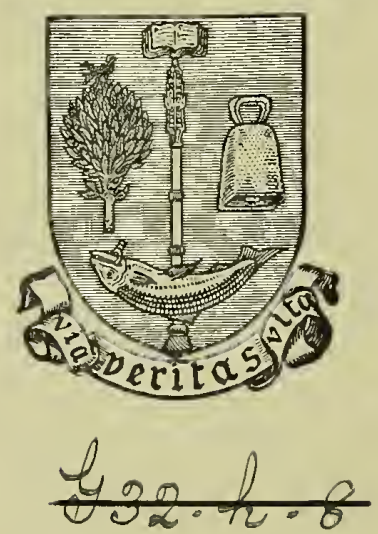

44. $y, 4 \cdot 28$. 
$\rightarrow \infty$

$=3 \neq=$

:

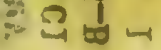





\section{Digitized by the Internet Archive}

in 2016 



\section{THE BRITISH}

\section{FLORA M E D I A ; -}

HISTORY OF THE

MEDICINAL PLANTS

OF

GREAT BRITAIN.

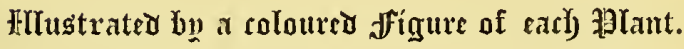

BY

BENJAMIN H. BARTON, F.L.S.

AN D

THOMAS CASTLE, M.D., F.L.S.

VOL. I.

LONDON :

HENRY G, BOHN, YORK STREET, COVENT GARDEN. MDCCCXLV. 



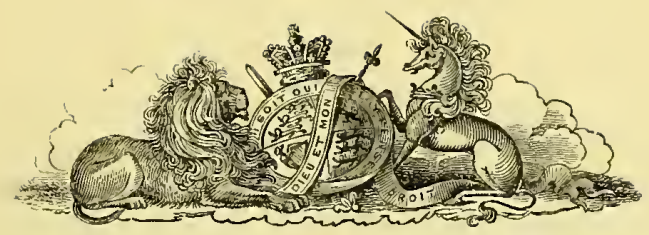

TO HIS MOST EXCELLENT MAJESTY,

\section{WILLIAM THE FOURTH,}

THE MUNIFICENT PATRON OF SCIENCE AND LITERATURE,

\section{THIS WORK,}

ILLUSTRATIVE OF BRITISH MEDICINAL PLANTS,

IS, BY PERAISSION,

MOST HUMBLY INSCRIBED,

BY HIS MAJESTY'S

FAITHEUL AND DEVOTED SERYANTS,

THE AU'THORS'. 



\section{PREFACE。}

Tнв great importance of the vegetable kingdom, whether it be considered as affording aliment, clothing, or medicine to the human race, is so obvious as to require no demonstration. If we recur to the earliest periods of the history of our globe, we observe the first dawn of medical science in the employment of those productions which, springing up in such abundance, and affording as they did to primeval man the chief, if not the only article of food, were naturally resorted to as the most suitable remedies for disease and pain. Through every succeeding age, plants have attracted a large share of attention, and have formed the chief resources of the healing art; and though for a time disregarded, in the rage for minerals and visionary schemes of treatment, it may be safely affirmed, that they con- . stitute the most potent, tractable, and valuable agents with which the physician is acquainted; and, as the clouds which still in some degree envelope their qualities and mode of action are dispersed, their importance will become more eminently conspicuous.

It is a trite remark, but not the less true, that the indigenous plants of Britain are too much neglected: this is doubtless, in great measure, the result of that undue preference for all that is novel and rare, and difficult to be procured, so cliaracteristic of human nature; to which may be added, that partial and disingenuous spirit of criticism which condemns without investigating, and would deprive an object of all its excellencies, because it is sanctioned by the voice of antiquity or the homeliness of rustic practice. 
The immediate design of this work is, to furnish an accurate description of all the medicinal plants indigenous to Britain, which appear entitled to that character, from the estimation in which they were held by the greatest and most skilful of the old physicians. That they were generally correct in their judgement is apparent from the fact, that several of the plants which they recommended have been allowed to sink in oblivion, and after many years' neglect, have again been successfully used by modern practitioners. This is well exemplified in the history of Foxglove, the more prominent effects of which were fully understood in the sixteenth century; it was admitted into the London Pharmacopœia in 1725, discarded in 1746, and has lately been restored with more than its pristine honours. How many more "blest secrets of the earth" remain yet to be discovered, it is impossible to predict; but if these pages should succeed in calling attention to one such plant, the labours of the Authors will be abundantly recompensed.

We must not omit to state, that the idea of this Flora was suggested by Mr. Waller's "British Domestic Herbal," a good practical work, containing a judicious selection of indigenous medical plants, illustrated by figures of the less familiar species: the best of these plates have been chosen to illustrate the present work, considerable additions and improvements being made, and new figures of at least an equal number being expressly engraved. To the letter-press of the above-mentioned volume, we are merely indebted for some extracts interspersed through the following pages. When we add that the synonymes of each plant have been carefully arranged,-its botanical character, its utility in the arts, or in rural and domestic economy, copiously described,-and its medicinal properties adduced from the best authorities,-we may fairly assert, that this work has a legitimate claim to originality, at least, as far as the term will apply to publications whose chief value consists in the ability they discover in affording a record of the experience of the past.

Throughout these pages popular utility has been kept in view, and an attempt has been made to render them available 
to the general as well as to the medical reader: for this purpose, a complete glossary of the terms employed will be found at the end of the work. Medical science, we are assured, rests on too firm a basis to fear the exposition and general diffusion of its principles ; and while no countenance should be given to the pernicious practice of tampering with drugs, circumstances often render a knowledge of simple remedies highly important and useful, whereby the benevolent individual may dispense to the indigent and suffering, that seasonable relief, without which the other offices of charity are incomplete and unavailing. For the same reason, the more familiar of medicinal plants cultivated in gardens, and easy of access, are introduced; the poisonous vegetables of Great Britain are particularly described, and directions given for counteracting their baneful effects.

In conclusion, we acknowledge ourselves peculiarly indebted to the valuable Apparatus Medicaminum of Murray; the Flore Médicale of M. Chaumeton; Woodville's Medical Botany; Smith and Sowerby's English Botany; De Candolle's Prodromus Regni Vegetabilis, \&c. 


\section{CONTENTS.}

VOL. I.

Abies communis ............. 309

Acanthus mollis.......... 48

Aconitum Napellus ......... 1

Acorus Calamus .......... 313

Esculus Hippocastanum ......162

Ethusa Cynapium ..........326

Agrimonia Eupatoria ......... 11

Ajuga Chamæpitys ..........369

Ajuga reptans ............113

Allium sativum .............347

Anchusa officinalis...........116

Anchusa tinctoria.......... 16

Anethum graveolens .........260

Angelica Archangelica ....... 18

Anthemis nobilis........... 157

Anthriscus Cerefolium ........166

Aquilegia vulgaris ............207

Arbutus Uva-ursi ........45

Arctium Lappa........... 119

Aristolochia Clematitis.......67 67

Arum maculatum .......... 24

Asarum europæum .......... 29

Asparagus officinalis ........ 33

Aspidium Filix-mas .........298

Bellis perennis . . . . . . . . . 244

Berberis vulgaris.......... 42

Beta vulgaris ............ 55

Betonica officinalis .... ..... 58

Betula alba.. ........... 63

Borago officinalis .......... 83

Bryonia dioica........... 97

Calamintha officinalis........131

Cardamine pratensis........232
Page

Carum Carui ..............134

Centaurea Cyanus......... 80

Chelidonium majus ......... 148

Chenopodium olidum ........36I

Colchicum autumnale.........187

Conium maculatum ......... 385

Convolvulus sepium .......6 61

Coriandrum sativum........ 216

Cuminum Cyminum .........236

Cuscuta europæa ...........263

Cytisus Scoparius........... 93

Daucus Carota .............. 139

Dianthus Caryophyllus ........ 183

Digitalis purpurea.........332

Eryngium maritimum .......285

Erythræa Centaurium........ 153

Eupatorium cannabinum ......392

Euphrasia officinalis . . . . . . 288

Fœniculum vulgare $\ldots \ldots \ldots \ldots 291$

Fumaria officinalis...........344

Galium A parine . . . . . . . . . 178

Geranium robertianum . . . . . .404

Geum urbanum........... 36

Glechoma hederacea .........366

Helleborus fotidus .......... 51

Helleborus niger............ 379

Hyoscyamus niger......... 395

Inula Helenium . . . . . . . . . 275

Iris Pseud-Acorus...........317

Lamium purpureum .........377

Leontodon Taraxacum .......249

Linum catharticum ......... 324

Linum usitatissimum .......320 
Lithospermum officinale... . . . .364

Colium temulentum .........254

Melissa officinalis ......... 39

Menyanthes trifoliata .........104

Nepeta Cataria .............145

Ophioglossum rulgatum....... 9

Paris quadrifolia ...........401

Peucedanum officinale ......407

Pimpinella saxifraga ......... 124

Polygonum Bistorta ........ 70

Polygonum Hydropiper ........73

Potentilla reptans ...........171

Primula veris .............221

Pyrethrum Parthenium.... . . . 303

Ranunculus acris ..........226

Rhamnus catharticus ........109

Ribes nigrum .............240

Rubus fruticosus ..........86
Page

Ruscus aculeatus ...........128

Salvia pratensis . . . . . . . . 175

Sambucus nigra ...........269

Scolopodendrium vulgare ......372

Scrophularia aquatica ........306

Sisymbrium officinale.........374

Smyrnium Olusatrum ....... 14

Solanum Dulcamara......... 76

Solidago Virgaurea...........358

Spiræa Filipendula .........266

Symphytum officinale .......211

Teucrium Chamædrys. ........352

Teucrium Scordium ......... 355

Trigonella Fœnum-grœcum....295

Tussilago Farfara...........201

Ulmus campestris . . . . . . . . 280

Veronica Beccabunga......... 89 


\section{LIST OF PLATES,}

AND DIRECTIONS TO THE BINDER,

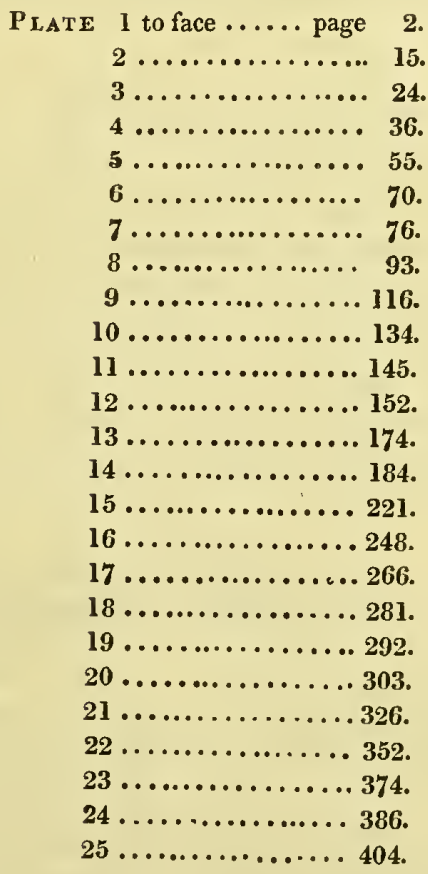





\section{B R I T IS H}

\section{FLORA MEDICA.}

I. ACONITUM NAPELLUS.

Common Aconite, Wolf's-bane, or Monk's-hood.

Class XIII. Polyandria.-Order III. Trigynia.

Nat. Ord. Ranunculaceer.

Gen. Char. Calyx petaloid, irregular; the upper leaflet helmet-shaped. The two upper petals or nectaries on long stalks, concealed beneath the helmet.

Spec. Char. Upper leaflet of the calyx arched at the back; lateral ones hairy on the inner side. Germens three to five, smooth. Leaves divided down to the petiole into five cuneate lobes, furrowed above.

S Y N O N Y MES.

Griek... axavizov. Theophrastus, Dioscorides.

Latin... $\left\{\begin{array}{l}\text { Aconitum coruleum seu Napellus. Bauh. Pin. } 183 . \text { Tourn. } \\ \quad \text { Inst. } 425 . \\ \text { Aconitum Napellus. Lin. Sp. Pl. 751. Eng. Fl. iii. p. } 31 . \\ \text { Aconitum vulgare. De Cand. Syst. vol. i. p. } 372 .\end{array}\right.$

French.. Aconit Napel; Coqueluchon; Capuchon de moine; Madriette. Italian.. Aconito Nappello.

Spanish.. Aconito Napelo; Matalobos de flor azul.

German.. Blaue Mönchskappe ; Sturmhut; Wolfswurz; Eisenhiitlein.

Dutch... Blaauwe Monnikskap; Blaauwe Wolfswortel.

Danish.. Blauemunke; Munkehœtte; Stormhat.

Swedish. Stormhatt.

Description.-The root is perennial, napiform, fleshy, of a dark colour without, whitish within, and sending off numerous fibres. The stem is erect, simple, subangular, smooth, and 
rises to the height of three or four feet. The leaves are alternate, palmated, and deeply divided into five elongated werlgeshaped segments, which are irregularly cut and toothed and furrowed on their upper surface; the lower leaves have long footstalks, but the upper are nearly sessile; the whole are dark green above, paler beneath, smooth, and shining. The flowers are arranged in a long cylindrical spike at the top of the stem; each flower is supported on a pedicel with two small bracteæ at the base. The calyx resembles a corolla, being of a deep violet colour : it consists of five unequal leaflets or sepals; the uppermost arched, helmet-shaped, concealing the petals; the lateral ones broad and nearly round; the lower oblong, divaricating. The two petals or nectaries stand on long incurved stalks, and are concealed beneath the helmet; each petal is furnished with a hooked spur and an oblong bifid limb. The stamens are numerous, converging, and support whitish anthers. The pistils are generally three in number, each furnished with a simple style and reflexed stigma. The capsules are usually three, oval, smooth, containing numerous black, angular, wrinkled seeds. (Plate 1, fig. 2.)

This plant can scarcely be considered a native of England, but it was found on the banks of the river Teme, in Herefordshire, in great abundance, by Sir J. E. Smith. It was first cultivated in the English garden about the year 1596, where it thrives well in moist and shady situations, flowering in June or July.

It grows wild in several of the Alpine regions of Europe, viz. in the mountains and hilly pastures of Germany, Switzerland, Hungary, Spain, Italy, and France*.

The etymology of the term Aconitum $\uparrow$ is rather doubtful. Some have derived it from áxóvเrog, devoid of dust, in reference to the rocky soil in which it grows, others from äxwr a javelin, because the savage nations poisoned their darts with its juice;

* De Candolle considers the species which he has named $A$. paniculatum, to be the one described by Störck; differing from the above in its loose corymbose spike, pale blue flowers, more convex acuminate helmet, and lateral sepals smooth within.

+ "Aconitum nascitur in nudis cautibus, quas Aconas nominant; et ideo Aconitum aliqui dixere, nullo juxtà ne pulvere quidem nutriente. Hanc aliqui rationem nominis attulere. Alii quoniam vis eadem in morte esset, quæ cotibus ad ferri aeiem deterendam, statimque admota velocitas sentiretur."-Pliny. 

but the most probable derivation is from Acone, a town of Bitliynia, near the shores of the Euxine Sea, which was famous for poisonous herbs, and especially the Aconite. The vernacular name, Monk's-hood, originated from the resemblance between the upper leaflet of the blossom and the hood or cowl of a monk; and that of Wolf's-bane, from the deadly effects of the plant upon the wolf; perhaps from a tradition, mentioned by an old writer, that wolves in a time of scarcity have torn up the roots and eaten them as food, and have soon after been found dead.

The poets fabled that the Aconite sprang from the foam of the monster Cerberus, when dragged to light by Hercules, and it is mentioned by Ovid as the principal ingredient in the poisonous draught prepared by Medea for the destruction of Theseus *.

Qualities.-The ancients appear to have considered this plant as the most virulent of all poisons, and, indeed; there are few spontaneous productions of nature that surpass it in venom. Its beauty has obtained for it a place in our gardens, and its inodorous flowers and vivid colours $\downarrow$ tend to mask its baneful qualities. A poet's fancy might trace something of its character in the fact that it loves the shade, and from the suspicious manner in which its petals hide themselves from the bright orb of day; but there is nothing to apprize the unwary of their danger.

It is so rank a poison, that many of the old writers employed the term Aconite as synonymous with all that is deadly in the vegetable world. Thus, in Shakspeare-

"Thou shalt prove a shelter to thy friends,

A hoope of gold to binde thy brothers in :

That the vnited vessell of their blood,

Shall neuer leake, though it doe worke as strong

As Aconitum, or rash gun powder."

2 H. IV., Act IV., Scene 4.

Every part of the plant is poisonous, especially the root and leaves; but as the latter have most frequently given rise to accidents, we shall relate some instances of their effects. When eaten,

* Vide Ovidii Met. lib. vii.

+ Linnæus imagined that the lurid colour of some plants indicated their noxious properties: hence he has denominated one of his natural orders hurida. 
or in any manner taken into the stomach, they produce a kind of intoxication, or rather madness, with a burning heat in the mouth and throat, numbness of the lips, cold sweats, faintings, and spasms, and generally prove fatal in a few hours. Even the juice introduced into a small wound in the thumb has been known to give rise to pains in the fingers and arms, anxiety and pain of the stomach, fainting, and finally copious suppuration and gangrene. The farina of the flowers accidentally blown in to the eyes has produced great pain and swelling and temporary blindness ; and the root, if kept long in the hand, is said to produce unpleasant symptoms *.

Willis $\nmid$ relates an instance of a man who accidentally ate some of the leaves in a salad, and died mad in a very short time. Matthiolus mentions the circumstance of four robbers under sentence of death, to whom this plant was administered, two of whom, after suffering the most violent torments, were saved by appropriate remedies; the other two died. One of these became, in a few hours, idiotic; the face was bathed in a cold sweat: a total loss of sensation, with fainting and spasms, followed. He vomited a quantity of bilious matter, the body swelled up, and he died in a state of apoplexy.

In the Philosophical Transactions ${ }_{+}^{+}$, is related the case of John Crumpler, who, at eight o'clock in the evening, ate a salad, into which, by some negligence, a few leaves of the Aconite had been introduced. He instantly felt a burning heat in the tongue and gums, and a considerable irritation about the cheeks. He imagined that his blood no longer circulated through the limbs, but felt no disposition to vomit. Perceiving that the symptoms increased, he drank about a pint of oil and a great quantity of tea, which produced vomiting. The symptoms, however, instead of disappearing, grew worse. At ten o'clock a surgeon was called in. The patient was found in bed, with the eyes and teeth fixed, hands and feet cold as ice, the body covered with a cold sweat, pulse scarcely sensible, and the respiration so short that it could hardly be perceived. Some spirit of hartshorn

* In a work entitled "Histoire des Plantes," published at Lyons, 1766, the writer goes so far as to say, "La racine tue pour ctre seulement longtemps tenue à la maine."

† De Animâ Brutorum, cap. xii. p. 494.

‡ Vol. XXXVIII., p. 287, anno 1734 . 
was administered to him, which induced coughing and vomiting; an infusion of the blessed thistle was then given till he had vomited copiously. He soon after passed a stool, and vomited afresh. The pulse rose a little, and intermitted with very great irregularity. A mixture was ordered for him of Theriaca Andromachi, Sal volatile, \&c. The next morning he was much better, and soon recovered.

A family near Lille were poisoned by this plant, in consequence of a tincture of the roots being mistaken for that of a species of lovage. The usual symptoms soon appeared, with swelling of the face, vomiting, and purging. Two of the individuals died.

The writer has been lately informed, on credible authority, of a case of idiotcy supposed to have been occasioned by this plant. The unfortunate sufferer was a young man, much attached to floricultural pursuits. He was suddenly taken ill, with the most violent symptoms produced by that class of poisons to which the Aconite belongs; but his maniacal state precluded any satisfactory conjecture as to the precise cause. A celebrated physician was called in, who by vigorous measures subdued the violence of the disorder, and the patient gradually recovered his health, but his mental faculties were fearfully impaired,- - he had no recollection of his former pursuits, - he was unable to comprehend the simplest matters, and was in fact taught his alphabet a second time. Being obliged to be treated as a mere child, he was one day shown for his amusement a collection of Plates, among which there happened to be a figure of the Aconite. Immediately he exhibited great agitation and alarm, pointing at the Plate and then at his mouth and uttering incoherent noises. His friends then suspected the true cause of his malady, and concluded that it must lave arisen from his incautiously swallowing some part of the plant, while engaged in his favourite avocation.

Linnæus relates that an ignorant surgeon who prescribed the leaves of the Aconite, on his patient refusing to take them, took them himself and died.

There are several other species of Aconite, all more or less poisonous, although from some superstitious notion, the A. Anthora was once considered wholesome and an antidote to the noxious species : its root was also esteemed the zedoary of the 
Arabian physician Avicena. The A. Lycoctonum or true Wolf's-bane is also poisonous, butLinnæus*, in his Lapland tour, mentions an interesting circumstance respecting it in his usual felicitous language, which must necessarily suffer by translation. "In my journey through Medelpadia $\uparrow$, I saw a woman gathering the leaves of this Aconite, and on asking her for what purpose they were designed, she replied they were intended to be used as food. To convince her of her danger, (for I thought she had mistaken the leaves for those of a species of Geranium, I implored, by all she held dear, not to prepare her last meal. But she with a smile said there was no danger,-she knew the plant well, and had so often gathered it for years as well as her neighbours, that she thought I could not be properly acquainted with it myself. I then entered her cottage and saw her cut the leaves in pieces and boil them with a little fat, so as to make broth, of which she partook, together with her husband, two children, and an old woman, thus,

\section{'Lurida terribiles miscent aconita novercæ ;'}

and what was most wonderful, with impunity." He then proceeds to enquire the reason of this apparent discrepancy, and concludes by remarking that the long continued boiling deprived the herb of its deleterious properties. There can be no doubt that this was the case, as the active principle in most of the Ranunculaceæ is extremely volatile, so that by simply drying them it is in great measure dispersed. The accurate observer just quoted, remarks that the Monk's-hood is fatal to kine and goats who come fresh to it; but that it does no injury to horses who eat it only when dry. After a thorough boiling, the most poisonous species might probably be eaten with safety.

Destructive, however, as are the European Aconites, they must yield to an Indian species called by Dr. Wallich+, Aconitum ferox. The root of this plant is the Bish or Visha of the natives of Northern India. It is in universal use for poisoning arrows, and a tank of water destined for the use of the British army in their halt during the pursuit of the Burmese, was found to be impregnated with this poison, which had been thrown in by

* Vide Flora Lapponica, edita studio Jacobi Edvardi Smith, p. 187.

+ A province of Norland.

‡ Vide Plantæ Asiaticæ Rariores, Vol. I., p. 33. 
the enemy before their retreat. It was fortunately discovercd in time to save the soldiers.

Treatment of Poisoning by Aconite.-The principal thing to be done in this and other vegetable poisons is, to procure vomiting by any means : the most speedy and effectual method is to force the finger or a feather down the throat, and keep up a titillation of the fauces. This will generally succeed, when the strongest emetics fail, and ought not to be delayed a moment after it is once ascertained that Aconite has been swallowed, as the danger is always in proportion to the quantity swallowed, and the length of time it remains in the stomach. After the poison has been evacuated, some cordial draught, or a little wine, may be given with advantage.

Bleeding should not be resorted to unless the pulse is full and apoplectic symptoms appear, neither should vinegar nor acidulous drinks be administered until the poison is evacuated, since all acids, wine, and alcohol increase its activity.

Medical Properties and Uses. - This poison, formidable as it is, has been subdued to the service of medicine, which has thus " out of seeming evil brought forth good." Baron Störck*, a German physician, was the first who attempted to apply the Aconite to the treatment of disease. ITe strenuously recommends it in gout, chronic rheumatism, intermittent fevers, scrofulous swellings, venereal nodes, and amaurosis.

An alkaloid has been lately discovered by Peschier, a Genoese chemist, in the Aconite, which has been denominated aconitine. It possesses the violence of the plant in a tenfold degree. The tenth of a grain killed a small bird with the rapidity of lightning, and a solution of onc grain in a drachin of alcohol, of which twenty drops were given to a guinea-pig, occasioned death in a few minutes. This potent drug has, however, been employed with apparent success by Dr. Turnbull $\downarrow$ in tic-douleureux, and other painful affections of the nerves.

Preparations of Aconite.-Sometimes the powder of the dried leaves is given, but this quickly loses its virtue, and cannot be depended upon. The most common preparation of the plant is its extract, or inspissated juice. This also is found to vary much in strength, according to the care used in its pre-

* Libellus de Aconito, \&c.-Vindod. 1763.

+ Treatise on Aconitine, by A. Turubull, M.D., London, 1834. 
paration. When recently prepared, it varies much in strength, and if a year old, is totally inert. We can hardly recommend this as a domestic remedy, as its operation requires the utmost vigilance of the physician. Should it, however, be resorted to, the following is the method of preparing it.

Extract of Aconite.-Bruise the fresh leaves of Aconite in a stone or iron mortar, with a wooden pestle, and squeeze them forcibly through a canvas bag, to obtain the juice, which must afterwards be evaporated in a flat vessel, placed in boiling water saturated with salt, till reduced to the consistency of honey. When cold, the extract should be preserved in a glazed earthen vessel, and moistened with a little spirit of wine.

It may be employed in any of the diseases above enumerated when they become obstinate and refuse to yield to the ordinary remedies. Not more than half a grain should be given at first, and the dose gradually increased, closely watching its effects. It may be taken twice or three times in the day. The most convenient form is in pills.

Dr. Turnbull, in his work just quoted, recommends the root* of the plant to be used in preference to the leaves, as it not only affords a more equal product, but contains more of the active principle. He directs a tincture to be made by digesting one part by weight of the powder of the dried root, in six parts by measure of strong alcohol for seven days, filtering through paper. The dose for adults is eight or ten drops, three times a day, gradually augmented to twenty drops.

From this tincture an ammoniated extract is prepared, which is directed to be used externally by friction in paralytic cases and long standing rheumatic affections. To each drachm of the tincture evaporated to the consistence of an extract, are added ten drops of liquor ammoniæ, and after the mixture has stood for a short time exposed to a gentle heat, an ointment is prepared in the following manner.

Ammoniated Extract of Aconite, 1 drachm.

Lard................. 3 drachms.

Mix. To be used by friction.

* As the old root, after the stems have shot up and produced flowers, is deprived of much of its vigour, great care should be taken to select the new roots. 


\section{II.}

\section{OPHIOGLOSSUM VULGATUM.}

\section{Common Adder's-tongue.}

\section{Class XXIV. Cryptogamia.-Order I. Filices.}

Nat. Ord. Filices, Ophoolossea.

Gen. Char. Capsules one-celled, two-valved, opening at the side, connate so as to form a compact two-ranked spike. Secds numerous, very minute. Involucre none. Spec. Char. Frond ovate, obtuse veinless; Spike cauline. S Y NON Y M ES.

Latin..... \{ $\begin{aligned} & \text { Ophioglossum sive Lingua serpentina. Park. Theatr. } 506 . \\ & \text { Ophioglossum. Raii Syn. 128. Ger. Em. 404. } \\ & \text { Ophioglossum vulgatum. Lin. Sp. Plan. 1518. }\end{aligned}$

French.... La Langue de Serpent ; Ophioglosse ; L'Herbe sans couture.

Italian... L Lingua di Serpente.

Spanish... Lengua de Sierpe.

Portuguese Lingua de Serpente.

German... Natterzunge; Schlangenzunge.

Dutch .... Adderstong; Natertong.

Description.-The Adder's-tongue rises from a small fibrous root, to the height of five or six inches from the ground. The stem is simple and bears but one leaf, which is ovate, obtuse, very entire, smooth, and free from veins. The spike rises from the base of the leaf, and is merely a continuation of the stalk; it is lanceolate, at first green, afterwards brown. The capsules are numerous, one-celled, two-valved, united by a membrane into a two-ranked spike, opening transversely when ripe, and discharging the seeds.

The singularity of this little plant will readily point it out to notice. Its narrow-pointed spike peeping up among the grass, may not inaptly be compared to a snake's tongue ; a peculiarity which seems to have obtained for it nearly the same name in all the European languages, as may be seen in the synonymes. It grows in inoist micadows and woods; and by the sides of rivulets. 
It must be sought for from the latter end of April to the beginning of June, after which time it entirely withers and disappears. Plate I., fig. 1., (a) the spike which has burst and discharged the seeds; $(b)$ the seeds magnified.

$\mathrm{J}$. Bauhin observes, that a variety is sometimes found with two or three spikes.

The generic name Ophioglossum is derived from the Greek op of fructification.

Adder's-tongue cannot be considered a poisonous plant, but it would appear from the character of its associates, in the following lines, that it was looked upon with some suspicion.

" 9th HAG. And I ha' been plucking (plants among)

Hemlock, henbane, adder's-tongue,

Night-shade, moone-wort, libbard's-bane;

And twise by the dogs, was like to be ta'en."

Jonson's Masque of Queenes, 3 charme.

Medical Properties. - This plant has been esteemed from time immemorial as an excellent application to wounds*, whether taken inwardly or applied externally. Ray speaks of it as possessing this property.

The most usual method of employing it is by infusing the leaf and spike of the plant in olive oil. This has been applied to wounds as a kind of balsam, and is, as Gerard remarks, of so beautiful a green, that many have supposed it made of verdigris.

An ointment may also be made with olive oil a pint, white wax four ounces, spermaceti three ounces: melt them over a slow fire, and when quite dissolved, add a good handful of the Adder'stongue, till it becomes shrivelled; then strain through a coarse cloth. Take care that the plant be not burnt.

In modern practice, these greasy ápplications are very little employed; but the ointment above mentioned may be used to advantage in old ulcers, and the oil or balsam of Adder's-tongue is good in the most violent sore throats.

- It is not unlikely that it first obtained this character from the resemblance of the spike to an adder's tongue, and thus, according to the doctrine of signatures, such a plant was a remedy for wounds occasioned by the adder. If so, its use would be soon extended to other wounds, ulcers, \&c. Of the fanciful doctrine of signatures we shall say more in our subsequent pages. 
III.

\section{AGRIMONIA EUPATORIA.}

\section{Common Agrimony.}

\section{Class XI. Dodecandria.-Order II. Digynia.}

\section{Nat. Ord. Rosaces.}

Gen. Char. Calyx inferior, five-cleft, covered with hooked bristles. Petals five, inserted upon the calyx. Fruit of two, small, indehiscent capsules, invested by the hardened calyx.

Spec. Char. Cauline leaves pinnate, with oblong, obtuse leaflets; terminal leaflet on a footstalk. Petals twice as long as the calyx.

\section{S Y N O Y M E S.}

Greek ..... surarogıv. Dioscorides.

Latin .... $\left\{\begin{array}{l}\text { Eupatorium veterum sive Agrimonia. Bauhin Pinax, } 321 ; \\ \text { Raii Syn. 202. } \\ \text { Agrimonia Ofticinarum. Tournefort Inst. } 301 . \\ \text { Agrimonia Eupatoria. Lin. Sp. Pl. 613. }\end{array}\right.$

French.... Aigremoine; Souheirette.

Italian... Agrimonia; Eupatorio de' Greci.

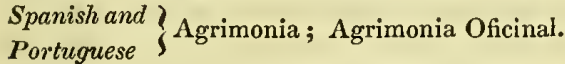

German ... Odermennig; Ackermennig.

Dutch..... Agrimonie; Lever-kruid.

Description.- The root is perennial, thick, fibrous, horizontal, knotted*, and covered with a dark coloured bark, beneath which there is a tissue of a fine red colour. The stem rises to the height of two or three feet, erect, cylindrical, rather rough, hairy, and generally simple. The leaves are alternate, interruptedly pinnate; the large leaflets deeply serrate ; the interme-

* Kach separate knot indicates a year's grewtl. 
diate smaller ones three to five cleft; between these are others extremely small and entire ; the whole ovate, hairy, and sessile, except the terminal leaflet, which is furnished with a footstalk. The stipules are two, opposite, amplexicaul, and deeply serrate. The flowers are disposed in a long terminal spike; they are small, yellow, almost sessile, with a three-cleft bractea at their base, and appear in June and July. The calyx is double; the interior or true calyx is permanent, composed of five ovate, pointed segments, externally surrounded with numerous rigid hairs, hooked at the end ; the exterior is hairy at the edges and the outside. The corolla is composed of five ovate, spreading petals, slightly notched at the end, of a bright yellow colour, and much longer than the calyx, into the throat of which they are inserted. The stamens are usually twelve, varying to five in number, arising from the calyx, shorter than the petals; the anthers are small, double, and compressed. The germen is inferior, double; the styles are two, each terminated by an obtuse stigma. The capsule is formed of the hardened calyx contracted at the summit, containing one or two smooth, oval, roundish seeds. Plate I., fig. 4., (a) represents the flower, from which the petals are detached; $(b)$ the ripe fruit.

The Agrimony is found in most of the temperate climates of the northern hemisphere. It grows abundantly in this country in hedge rows, borders of fields, and road sides, which it embellishes during the summer months with its lofty spike of golden bloom, and very elegant leaves. The curious provision made by nature for disseminating the species is deserving of remark. The fruit is beset with long rigid hairs, hooked at the end, by means of which it adheres to the person or animal that may happen to come in contact with it.

The learned are not quite agreed as to the origin of the word Agrimonia. Some suppose it to have been derived from ager,

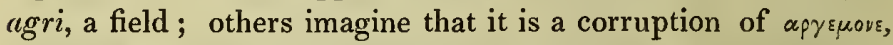
a name given by the Greeks to a plant that was reputed to cure cataract of the eye. It was called Eupatoria, from ${ }^{5} \pi \alpha p$, r $\pi \alpha \tau \sigma \varsigma$, the liver, in the diseases of which organ it has in all ages been esteemed an effectual remedy, and hence the provincial name Liverwort.

Qualitiss.-The whole plant, and especially the root, in spring, exhales an agreeable odour, which is, however, rather 
feeble, and is soon lost by drying: the flowers, when fresh gathered, says Withering, smell like apricots. It is bitter and astringent to the taste, but is eaten occasionally by sheep and goats; horses, cows, and swine refuse it.

When the plant is beginning to flower, it will dye wool of a bright nankeen colour, and gathered in autumn a darker yellow. Dambourney recommends for this purpose a strong infusion to be made in water, and a weak solution of bismuth to be used as a mordant. The astringent qualities of the plant have recommended it also for dressing leather.

Geoffroy remarks, that the juice of the leaves imparts a slight red tinge to blue paper; and an infusion of them instantly blackens a solution of sulphate of iron.

Medical Properties and Uses.-This plant, though rejected by modern physicians, is of considerable efficacy in removing obstructions, and has been always celebrated as a valuable remedy in diseases of the liver and spleen, as well as many chronic complaints. It is recommended also for spittings of blood and bloody urine. The best method of using it is in infusion: a handful of the dried leaves are to be put into a vessel, and a quart of boiling water poured on them; and, when cool, to be strained. Or a tea may be made of five or six of the dried leaves to half a pint of boiling water, with the addition of a little sugar. By means of this drink some very obstinate indurations of the liver have been removed. It should be taken in a morning fasting, and repeated twice or three times in the day; a tea-cup full at least each time. It has been found also extremely serviceable in cutaneous eruptions, and is an excellent purifier of the blood. Externally it is useful in fomentations, boiled with chamomile flowers, St. John's wort, and wormwood. As a vulnerary it has enjoyed as much fame as the Adder's-tongue: boiled with wheaten-bran in wine-lees, and applied to luxations, sprains, $\&$ c., it was esteemed very efficacious, and it certainly had a better claim than many plants, to that now obsolete title. It forms a very good gargle for sore throats.

The plant should be gathered when in blossom, and carefully dried in the shade. It may then be preserved in boxes, or in bundles hung up in a dry place. 
IV.

\section{SMYRNIUM OLUSATRUM.}

Common Alexanders.

Class V. Pentandria.-Order II. Digunia.

Nat. Ord. Umbellifere.

Gen. Char. Fruit broader than long, concave at each side, with six acute dorsal ridges; interstices convex, with many vittæ. Calyx obsolete. Petals lanceolate or elliptical, inflexed at the point, entire--Involucre various. Flowers nearly regular, partly abortive.

Spec. Char. Cauline leaves ternate, stalked, serrate.

S Y NON Y M ES .

Latin ..... $\left\{\begin{array}{l}\text { Smyrnium. Matthiolus, 773. Raii Syn. 208. } \\ \text { Hipposelinum Theophrasti. Bauhin Pinax, 154. Ger. Em. } 1019 . \\ \text { Smyrnium Olusatrum. Lin. Sp. Pl. 376. }\end{array}\right.$

French.... Maceron commun.

Italian.... Macerone.

Spanish... Apio caballar.

Portuguese Olusatro.

German... Smyrnenkraut.

Dutch.... Veldeppe.

Description.-The root is biennial, large, thick and long; blackish externally, and white within; aromatic, but somewhat acrid and bitter. The stem is cylindrical, branched, and furrowed, and rises to the height of three or four feet. The leaves are of a bright yellow green; the lowest thrice ternate, the uppermost simply ternate, with a very broad membranous base; the leaflets are very large, broadly ovate, lobed and serrated, smooth and shining. It has neither general nor partial involucre. The flowers are small, numerous and irregular, of a light yellowgreen, and arranged in very dense rounded umbels. The flo- 

rets in the centre bear only stamens. The calyx is very small, and scarcely perceptible. The petals are five, ovate-lanceolate, entire, incurved at the points. Stamens five. Germen inferior, with two simple styles and stigmata. Fruit of two indehiscent pericarps or carpels, somewhat crescent-shaped, channelled, nearly black when ripe._Plate II., fig. 1., (a) floret; $(b)$ fruit ; $(c)$ the fruit cut transversely.

Alexanders is generally found in waste places near the sea, and not unfrequently about inland towns. It is very abundant on the western coast, and in the south-western part of the isle of Anglesea. From its being often met with in the vicinity of the ruins of abbeys, $8 c$., we may infer that it was held in great esteem by the monks. It flowers in May and June, and the seeds ripen in August.

This plant appears to have derived its name Smyrnium from ouvpra, myrrh, in allusion to the scent of its juice, which smells like myrrh, as observed by Pliny. It takes its specific name from olus, a pot-herb, and atrum, black, probably from the dark colour of the fruit. The English name Alexanders is a corruption of Olusatrum, or, as some think, derived from Alexandria in Egypt, whence it was supposed to have been originally brought.

General Properties and Uses.-Alexanders was formerly cultivated in our gardens as a culinary herb, but it is now almost supplanted by the celery, which it somewhat resembles in flavour. It was cultivated much in the same manner as celery, and like it, was dug up for use in autumn and winter. The leaves too were boiled in broths and soups. It is an aromatic herb, but too strong and pungent to be agreeable.

Medical Properties.-The root and seeds of this plant are reputed diuretic and emmenagogue. Dioscorides affirms, that the latter are good for such as are afflicted with dropsy.

The seeds powdered are said to be highly carminative : taken in the dose of from half a draclim to a drachm in a glass of wine, they dispel wind, relieve strangury, and promote the menses. The expressed juice of the leaves has been highly extolled as a specific in gravel and diseases of the urinary passages, taken in the quantity of from three to six ounces mixed with white wine. 


\section{ANCHUSA TINCTORIA.}

Alkanet, or Dyer's Bugloss.

Class V. Pentandria.-Order I. Monogynia.

Nat. Ord. Boraginee.

Gen. Char. Calyx 5-cleft or 5-parted, persistent. Corolla funnel-shaped; tube straight, its mouth closed with five prominent scales. Anthers included. Stigma emarginate. Nuts concave at the base.

Spec. Char. Leaves oblong. Bracteæ longer than the 5 -parted calyx. Valves of the corolla shorter than the stamens.

S Y NON Y M ES.

Greek .... аухочб๘. Hippocrates.

Latin.... \{ Anchusa Monspeliana. Bauh. Hist. III., 584. Raï.Hist. 496.

\{ Anchusa tinctoria. Lin. Sp. Pl. 132.

French.... Orcanette tinctoriale.

Italian.... Ancusa; Alcanna.

Spanish ... Anchusa.

German ... Alkannawurzel ; Farben Ochsenzunge.

Dutch.... Winkelossetung.

Danish.... Rod oketunge.

Description.-The root is perennial, long, woody, fibrous, and externally of a purplish red colour. The stem is thick, round, hairy, branched, and rises about eighteen inches in height. The leaves are oblong-lanceolate, somewhat obtuse, hairy, and without footstalks. The flowers are sessile in the axils of the floral leaves, and terminate the branches in close spikes. The calyx is persistent and divided into five deep, oblong, erect segments. The corolla is funnel-shaped; the stamens are enclosed in the tube, which is closed at the mouth by five small 
prominent scales*. The five filaments are short, and are furnished with simple anthers. The germen is four parted, the style simple, and the stigma bifid. The fruit consists of four achenia or small nuts, invested by the persistent calyx. Plate I., fig. 3, (a) the corolla and stamens; (b) the pistil; (c) the persistent calyx investing the fruit.

This plant is a native of the soutl of Europe, and was originally brought to this country from Montpellier, about 250 years since. It is sometimes cultivated in our gardens, but its roots never attain, in this climate, that fine colour for which the foreign are so much prized. It flowers from June to October.

The generic name of this plant is derived from arxovoa, paint, because the roots were formerly used to afford a dye for staining the face.

There is another species, the Anchusa officinalis, or common Alkanet, which is sometimes, though rarely, found wild in this country, and was once reckoned a valuable emollient, but it is now held in little esteem.

Qualities and General Uses.-The bark of the root has been long valued for the fine red colour it affords. It is imported into this country, chiefly from France, in long twisted pieces of a dusky red hue. It imparts a deep red colour to alcohol, ether, oils, and wax, but to water it only yields a dull brown. It is used by dyers, and also by cabinet-makers for staining wood, and is said to be employed by vintners for staining the corks of their port wine bottles, or for colouring and flavouring the spurious compounds sold as port wine.

Medical Properties.- The Alkanet was formerly recommended in several diseases, particularly as an astringent. It is now used almost entirely for colouring oils, ointments, \&c. It contains a peculiar colouring principle, which Dr. John calls Pseudo-Alcannin.

* De Candolle, in his Flore Francaise, states that the Dyer's Alkanct is not the Anchusa Tinctoria of Linnaus, since it does not agree in the generic character, the moutl of the tube of the corolla being naked, not closed with scales; moreover, Linnæus says Anchusa tomentosa, while this plant is clothed with hairs. In the first editions of the "Species Plantarum," we find Lithospermum tinctorium, only; but in the editions by Gilibert and some others, this plant is removed to the genus Anchusa. De Candolle asserts that the plant called Orcanette, used for its dye, and growing abundautly in the south of France, (whence it is well known the Alkanet of the shops is bronght,) is a true Iithospermum. 


\section{ANGELICA ARCHANGELICA.}

Garden Angelica.

Class V. Pentandria.-Order II. Digynia.

Nat. Ord. UmbeLimfere.

Gen. Char. Fruit sub-compressed, 2-winged; carpels with three elevated dorsal ridges, the lateral ones spreading into the wings of the fruit. Caly $x$ an obsolete margin. Petals elliptical-lanceolate, entire, equal, inflexed at the point.-Universal involucre scarcely any.

SpEc. Char. Leaves doubly pinnate, ovate-lanceolate, serrate; the terminal leaflet lobed.

\section{S Y NONY M S.}

Latin.... $\left\{\begin{array}{l}\text { Angelica Sativa. Bauh. Pin. 155. Ger. Em. 999. Raii. Syn. } \\ \text { 208. } \\ \text { Imperatoria Sativa. Tournefort Inst. 317. } \\ \text { Angelica Archangelica. Lin. Sp. Pl. 360. }\end{array}\right.$

French.... Angelique des Jardins.

Italian ..... ?

Sparish .... Angelica.

Portuguese.)

German ... Angelika; Angelikwurzel ; Gartenangelik ; Brustwurz.

Dutch..... Angelika; Engelwortel.

Danish.... Angelik; Fadnobusk.

Swedish ... Angelik.

Polish .... Dziegel agrodni.

Description.-The root is biennial, thick, fusiform, with numerous fibres, resinous, brown externally and white within. The stem is erect, from four to five feet high, thick, cylindrical, jointed, striated, fistulose, smooth, and sends off numerous branches, which are terminated by large spreading umbels. The leaves are large, alternate, doubly winged, and composed of ovate, serrated, pointed leaflets, often three-lobed, especially the ter- 
minal one; the footstalks are membranous at the base, and much dilated. The flowers are numerous, of a greenish-white colour, and arranged in large, nearly spherical, many-rayed umbels. The calyx is scarcely distinguishable. The petals are five, nearly equal, oblong-lanceolate, and inflexed at the point. The stamens are five, spreading, and longer than the petals. The germen is inferior, ovate, furrowed; with two short styles, at first erect, afterwards recurved. The fruit is somewhat compressed, and furnished with two broad wings; the carpels are marked with three acute ridges at the back, the lateral ones vanishing into the wings of the fruit. The seed is solitary in the carpel, free, ovate and pointed. Plate III., fig. 1, (a) the ripe fruit.

The Angelica grows wild in Lapland, Norway, Sweden, Austria, Silesia, on the Alps and Pyrenees, and is especially abundant on the banks of rivers in those countries. It was cultivated in the English garden prior to the year 1568, and is now completely naturalized, having been found at Broadmoore, near Birmingham, and in marshy ground adjacent to the Thames, about Woolwich. It flowers from June to September.

This plant has received its imposing name from angelicus, on account of its medicinal virtues, especially from its being considered efficacious against pestilential diseases. It is called Archangelica, from a $x^{\prime} x$, pre-eminence, because of its superiority to the other species of the genus.

CULTURE.- "It delights to grow in a very moist soil. The seeds should be sown soon after they are ripe, for if they are kept until the spring, scarcely one in forty will grow. When the plants are advanced about four inches in height, transplant them into rows, from two to three feet apart. They thrive best upon the sides of ditches or pools of water. The second year after sowing they will shoot up to flower, therefore, if you wish to continue their roots, you should cut down the stems in May, which will occasion their putting out heads from the sides of the root, and by this means they may be continued three or four years. When they are cultivated for seed, new plantations should be annually made to supply the place of those which die, for when they are permitted to seed, they last but two years. For candying, the young shoots and leaf-stalks are used, being cut while they are young and tender, in May."-Miller.

Qualities AND general Uses. - The Angelica is one of the few aromatics of European origin. Every part of the recent plant, particularly the root, is fragrant and agreeable, with an aroma somewhat resembling that of musk. The taste is sweetish 
at first, and balsamic, followed by a warmth and bitterness which is by no means disagreeable. On wounding the fresh root in the spring, it yields a yellowish, odorous juice, which being slowly dried, proves a valuable gum resin, very rich in the qualities of the plant.

The leaves and seeds do not long retain their virtues when kept, but the root may be preserved for a considerable time, if thoroughly dried, and well defended from damp. Dr. Lewis suggests to dip the roots, after being dried, in boiling spirit. Rectified spirit extracts the whole of the virtues of the root; water but very little.

The Laplanders consider this plant as one of the most important productions of their soil. Linnæus, in his interesting work before mentioned, informs us that they give different names to the various parts and states of the plant. The root of the first year before the stem has shot up they call urtas. This they extol as the best remedy for preserving health to a remote period. They also masticate the dried root in the place of tobacco. The stem, cut down before the umbels are quite unfolded, and stripped of its outer rind, is to them an apology for the fruits of more genial climates, and furnishes no inconsiderable part of their food. The Icelanders eat the stem and roots of Angelica raw with butter, and the Norwegians are said to make bread of the roots.

Cattle in general are fond of this plant, and the milk of cows that feed on it is said to have a peculiar taste and smell. Horses refuse it.

There is another species, the Angelica sylvestris, or wild Angelica, which, though much shorter, resembles the preceding in habit and botanical characters, but is greatly inferior in quality. It has been administered, however, by some practitioners with success, in hysterical and epileptic complaints. Tanners have discovered that it has properties analogous to those of oakbark, and a tincture has been prepared from the leaves which dyes woollen stuffs of a golden yellow colour. Bees obtain a fine honey from its flowers.

Medical Properties and Uses.-The Angelica is an excellent tonic and carminative, and although it is held in little repute amongst the modern English physicians, it is very highly commended by all the older ones. Etmuller and Sydenham 
speak of it in the highest terms, and they particularly recommend it in colics and flatulence, and in obstructions of the menses. A decoction of one ounce of the dried root, boiled in three pints of water to a quart, is an cxccllent sudorific and cordial, in the dose of a wine-glassful every two or three hours. In this form it las been found of great service in typhus fevers. The powder of the dricd root is also given in substance, from hatf a drachm to a drachm. This is a useful addition to the Peruvian bark in agues, in the dose of a scruple to half a drachm of the bark every thrce hours. It is likewise an excellent ingredient in the compound tincture of bark.

The following will be found both an agreeable and highly useful tincture in all disorders arising from flatulence, indigestion, or any complaint of the stomach and bowels, and a good preservative against these complaints.

Take of Powdered red Peruvian Bark, one ounce and a half;

Dried Orange peel,

Angelica root bruised, of each one ounce;

Braudy one pint.

Infuse the ingredients in the spirit, and let them stand fourteen day's in a warm place; then filter through paper.

This cordial tincture may be taken in the dose of two teaspoonfuls to a table-spoonful in any lome-made wine. In marshy countries, where agues are prevalent, this will be found a good preventive against those complaints, as well as a remedy for them when they have made their attack. In the former case, the dose above mentioned should be taken in the morning just before going out of the house; but in the latter a full dose must be taken every two hours in the abscnce of the fit. A wine-glassful of the tincture by itself, taken a few minutes before the accession, will frequently prcvent the fit; and if from twenty to thirty drops of laudanum be addcd, will seldom or never fail.

In the old Pharmacopoias, thcre was a compound spirit of Angelica, which was certainly not laid aside bccause found to be useless, but because it is too complicated for modern Pharmacy. Suclı persons, lowever, as suffer much from wind in the stomach and bowels, or hystcrical affections, will find the greatest advantage fiom its use. It maly be thus prepared :- 
Take of Angelica Root,

Leaves of the Blessed Thistle, of each three ounces ;

Balm and Sage, of each two ounces;

Angelica seeds, three ounces ;

Sweet Fennel seeds, one ounce :

Let the dried herbs be coarsely powdered; then add,

Cinnamon, one drachm;

Cloves and Mace, of each half a drachm;

Nutmeg and Lesser Cardamom seeds, of each half a drachm ;

Allspice and Saffron, of each half a drachm.

Infuse the whole for several days in two quarts of brandy, or proof spirit and then draw off by distillation the same quantity. After this quantity has been obtained, the last runnings of the still may be kept separate. It will make a pleasant water to administer any carminative tincture or spirit in. This was called the Compound Spirit of Angelica, and is still much in use in the northern countries. It may be given with great advantage in typhus fevers, and is a good preservative against those diseases where people are exposed to the contagion. The dose in general is a table-spoonful, but when used as a preservative, should be taken in a larger quantity ; - two or three spoonfuls at a tinıe, in any kind of vehicle, or simply diluted with water.

A very elegant distilled water may be obtained fiom the dried leaves, which possesses the same aromatic properties as the plant, and is a pleasant vehicle for other more nauseous medicines.

The fresh stalks of the Angelica are made by confectioners into an agreeable sweetmeat, which contains much of the virtues of the plant. In the Pharmacopœia of Paris, the following mode of preserving it is given :-

Take of young stalks of Angelica, any quantity.

Remove from them the outer rind, cut them into pieces three or four inches long, whiten them in boiling water, and lay them on a sieve that the water may drain from them. Then put them into a syrup made of purified sugar, boil till aqueous vapour ceases to ascend, and leave them to dry in a stove chamber on a wooden frame.

An essential oil may also be obtained from the root, thus

Take of Root of Angelica.... 25 paits.

Water .......... 75 parts.

Common Salt ....... 3 parts.

Distil, and separate the oil.

The roots should be dug in the autumn, and the young stems for candying in May.

The quaint and amusing Gerard thus describes the manifold virtues of Angelica :- 
" The roote of Garden Angelica, is a singular remedie against poison, and against the plague, and all infections taken by euill and corrup aire, if you do but take a peece of the roote and holde it in your mouth, it doth most certainly driue away the pestilentiall aire, yea, although that corrup aire have possessed the hart, yet it driueth it out again by vrine and sweate, as rice and treacle doth and such like Antipharmaca. Angelica is an enemie to poisons : it cureth pestilent diseases if it be vsed in season; a dram waight of the powder hereof is given with thin wine, or, if a feauer be vehement, with the distilled water of Carduus Benedictus or of Tormentill, and with a little vineger and by itselfe also, with treacle of vipers added. It openeth the liuer and spleene.... It extennuateth and maketh thinne grosse and tough flegme.... It is reported that the roote is auaileable against witchcraft and inchantments, if a man carrie the same about him as Fuchsius saith.... It is a most singular medicine against surfeiting and lothsomnes to meate; it helpeth concoction in the stomacke and is right beneficial to the hart : it cureth the bitings of mad dogs and all other venomous beasts." Herball, p. 849.

The Laplanders, during that part of the year which they pass in the woods, are subject to a severe kind of colic, against which the root of Angelica is one of their chief remedies. They also frequently mix the unexpanded umbels with the leaves of sorrel, and boiling them down in water to the consistence of a syrup, mix it with rein-deer's milk, and thus form a stomachic and astringent medicine. 


\section{VII.}

\section{ARUM MACULATUM.}

Common Arum, Cuckow-Pint, or Wake-Robin.

Class XXI. Monceia.-Order VII. Polyandria.

Nat. Oid. Arolde.

Gen. Char. Spathe of one leaf, convolute at the base. Perianth 0. Spadix with germens at the base. Stamens (sessile) near the middle of the spadix, which is naked above. Berry one-celled, many-seeded.

Spec. Char. Leaves all radical, hastato-sagittate, lobes deflexed. Spadix club-shaped, obtuse, shorter than the spathe.

\section{SY NONYMES.}

Greek..... upov.

Latin .... $\begin{aligned} & \text { Arum vulgare. Bauhin Pinax, 195. Gerard. Em. 834. } \\ & \text { Arum. Raii Synopsis, 266. } \\ & \text { Arum Maculatum. Lin. Sp. Pl. 1370. }\end{aligned}$

French.... Arum; Gouet; Pied de Veau ; Gouet Tacheté.

Italian .... Aro; Iaro; Gicaro ; Pie Vitellino.

Spanish.... Aro; Aro Manchado.

German.... Aron; Aaronswurzel; Kalbsfuss; Magenwurzel.

Dutch ..... Aron; Kalfsvoet.

Danish..... Dansk Ingefer.

Description.-The root is tuberiferous, about the size of a pigeon's egg, furnished with numerous slender fibres, brownish externally, white within, fleshy, and yields a milky juice. The leaves spring immediately from the neck of the tuber, they are large, halbert-shaped, or somewhat sagittate, and very entire; their surface is smooth, slining, dark green, veined, and often marked with dark spots. The flower, which is remarkable for its form, is enclosed in an ample, concave, convolute spathe, erect, pointed, pale green, and sometimes spotted within. The spadix is simple, shorter than the spathe, club-shaped, and of a purplish or buff colour at the extremity, the lower part bearing 

the flowering organs. The anthers are sessile on the middle of the lower half of the spadix; above and below them is a ring of abortive stamens, terminated by filaments, called by Linnæus, nectaries. The germens are placed at the base of the spadix; they are numerous, obovate, and of a greenish yellow colour. The fruit consists of several globular berries, collected into an oblong spike, which remains during winter after the leaves and spadix have decayed; the berries are of a bright scarlet colour, globose, succulent, one-celled, and contain one or more hard, roundish seeds. Plate III., fig. 2, (a) the ripe fruit; $(b)$ berry detached from the spadix; $(c)$ the same cut vertically to shew the seed.

The common Arum, familiar to children by the name of lords and ladies, is found under almost all climates; it is frequent in most parts of England, rare in Scotland and Ireland. It grows in damp shady places in groves and hedges, flowering in April and May, and ripening its fruit in autumn.

The generic name is supposed to be derived from the Hebrew jaron, a dart, in allusion to the shape of the leaves; or from an Egyptian word by which some plant of the kind was designated. The vernacular names are not peculiarly expressive, but it is sometimes called calf's-foot, from the shape of the leaf, and is known by the same appellation in many of the European languages.

There are nearly fifty species of Arum described, the majority of them natives of the tropics. The Arum Dracunculus, or common Dragon Arum, brought from the south of Europe, is a very remarkable plant; the leaf-stallss are spotted like the belly of a snake, and the flower exhales a putrid odour equal to that of carrion. 'The root of A. Colocasia is eaten in Egypt and the Levant, and the leaves of A. Esculentum and some other species are similarly used in the West Indies.

Qualities and general Uses.-Every part of the common Arum is acrid, styptic and pungent, and contains a juice which turns syrup of violets green, reddens litmus paper, and is coagulated by the mineral acids. Vauquelin has detected malate of lime in the expressed juice. The leaves are so acrimonious, that applied to a delicate skin they irritate and inflame it, and sometimes produce blisters. The roots, however, are the most powerful; when recent they are nearly white and inodorous, alnost insipirt to the taste at first, but soon produce at sensation of burming and pricking as if by necelles, which lasts for several 
hours, and can only be mitigated by oily or mucilaginous drinks. This acrimony is almost lost in drying, and is quite dissipated by submitting the roots to the process of baking or boiling *.

A very white and pure foecula resembling arrow root may be procured, by reducing the fresh roots to a pulp and placing it on a strainer. Repeated portions of cold water are then to be poured on it, which carry the farinaceous particles through the strainer, and leave behind the fibrous part. The foecula which subsides is deprived of its acrimony by drying, and affords a delicate and nutritious food. Dr. Hooker, in his British Flora, states, that this amylaceous substance is prepared in great quantities at Weymouth, and in Portland island. It is also sent to London under the name of Portland sago.

Tournefort mentions, that in Lower Poitou the women cut the stalks of the plant while in flower, and macerate them for three weeks in water, which they change every day; then pouring off the water, they dry the residue and use it instead of soap to wash their linen. According to Dr. Withering, the French cypress-ponder is merely the dried root pulverised. A distilled water is also obtained from it, which is equally celebrated as a cosmetic.

Swine eat the leaves in spring with impunity, and the berries are devoured by birds. Mr. Curtis thinks that pheasants eat the roots occasionally.

There is a singular circunstance connected with the growth of this, in common with other allied species. At the period of fecundation, it was discovered by Lamarck, and others that the spadix evolved a considerable degree of heat. Brogniart $t$ found in his experiments on the Colocasia odora, that the heat thus disengaged was most intense when the anthers were in full vigour, and amounted to $52^{\circ}$ (Fahr.) above tlat of the surrounding air. The Arum tribe would thus seem to partake in some degree of the nature of animals; and this resemblance is more strik-

- This is not the only instance in which food is obtained from poisonous plants. Linnæus ("Flora Lapponica," p. 258) states that in Lapland a wholesome bread is prepared from the roots of the Calla palustris, which are extremely acrid in their recent state, "ignis ferme instar." The roots of the Jatropha Manihot, the Tapioca of South America, abound in a noxious juice, but when this is dispersed by maceration in water and drying, they become a valuable article of food.

+ Nouv. Ann. du Museum, vol. iii. 
ingly evinced in the putrescent odours of some species, and the azote that chemical analysis has detected in them.

Poisonous Properties.-The common Arum in its recent state is undoubtedly poisonous. Children in particular are apt to mistake the leaves for those of sorrel : they occasion a very considcrable degree of excoriation, and sometimes hæmorrhage from the tongue and fauces.

Bulliard relates the following case: "Three children ate of the leaves of this plant. 'They were seized with horrible convulsions, and with two of them assistance was unavailing, as they were unable to swallow anything. They died in a few days. The third was saved with difficulty. Its tongue was so swelled that it filled the whole cavity of the mouth, but this symptom was relieved by bleeding, and copious draughts of milk and olive oil were found serviceable."*

The treatment in poisoning by Arum is the same as that employed for other vegetable irritants. The noxious substance should be removed by emetics, unless spontaneous vomiting occurs. Sulphate of zinc $\uparrow$, in doses of from ten to fifteen grains every half hour, is a good emetic. Leeches may be applied to the throat, and mucilaginous drinks should be freely administered, until medical aid can be obtained.

Medical Properties and Uses.-The root of this plant is the part employed in medicine, and is a remedy of great value in some of the most obstinate diseases. It is not frequently used in modern practice; not because its properties are doubted, but on account of its excessive acrimony when fresh, and the uncertainty of its action when dried. It is not to be supposed, however, that the dried root, carefully preserved, is totally divested of those active and valuable properties which accompany it when first prepared; on the contrary, it is still a very valuable medicine in a larger dose. It has been given with very great success in the lumoral or moist asthma, in severe chronic rheumatisms, in chlorosis or green sickness, jaundice, obstructions of the viscera, and in dropsy. It exerts considerable power over that thick, viscid, tenacious matter which frequently abounds in the stomach and bowels,

- Histoire des Plantes Venéneuses, p. 84.

+ Commonly called "White Vitriol." 
and gives rise to the most alarming diseases, defying the power of emetics or cathartics to dislodge it. The Arum, by means of its penetrating and volatile properties, acts quickly on this glairy substance, and alters its nature so as to fit it for easy expulsion.

It has been found successful in removing the most inveterate cutaneous diseases, when accompanied by occasional purging. Sydenham employed it successfully in severe chronic rheumatism, particularly of the scorbutic kind, in which disease he esteemed it an invaluable specific; he prescribed it also in dropsies, and in the advanced state of the gout. A severe general dropsy has been known to yield to a prescription of that renowned physician, in which Arum and Angelica were the most prominent articles. Eimuller extols the fresh-prepared root as a most excellent stomachic in cases of extreme prostration of appetite. He recommends the root to be cut into very small pieces and taken in brandy. Geoffroy recommends the powder in obstinate intermittent fevers, in the dose of a scruple to half a drachm. Bergius and Gilibert speak of its efficacy in the same diseases, and in certain kinds of head-ache.

The time for digging up the roots is in autumn, and they may, be preserved fresh for nearly a year if kept buried in sand in a cool cellar. When intended for immediate use, they should be dried slowly, with very little heat, and sliced; when perfectly dry, they should be powdered, and kept in small well-stopped bottles, in a cool place. The dose, in substance, should be from ten grains to a scruple or half a drachm, taken in honey, or some thick mucilaginous drink, to guard against its acrimony in the mouth. Lewis recommends the fresh root to be heat up with some of the gum-resins, such as galbanum, (or the compound called the gum-pill,) until they form a mass that will allow of being made into pills. In this manner, their virtue will be preserved, and the form is very advantagecus for taking the medicine. Its properties are also well preserved in a conserve, as they cannot be extracted by any menstruum. The following is the method of preparing it:

Take of fresh Root of Arum, bruised, half a pound;

Double-refined Sugar, a pound and a half.

Beat then together in a mortar, till they are well mixed, in the form of a conserve. This mity be taken in the dose of a drachm to two drachms. 


\section{VIIT.}

\section{ASARUM EUROPAUM.}

\section{Asarabacca.}

\section{Cless XI. Dodecandria.-Oreler I. Monogrnia.}

\section{Nal. Ord. Aristolochiz.}

Gen. Char. Perianth single, 3-cleft, superior. C'apsule six-celled, coriaceous, crowned.

Spec. Char. Iueaves binate, reniform, obtuse.

SYNON XMES.

Greek ..... usugs,. Dioscorides. Latin ..... \{ Asarum. Bauh. Pin. 197. Ger. Em. 836. Raii. Syn. 158.

French .... Asaret; Cabaret; Rondelle; Oreille d'homme; Nard Saurage. Itatian.... Asaro.

Sparishand,

Portuguese. $\}$ Asaro.

German... Wild Narde; Haselkraut.

Dutch .... Hazelkruid ; Mans-ooren.

Swedish.... Hasselört.

Arabic.... Asarun.

Description.-The root (rhizoma) is perennial, creepingt tortuous, jointed, fleshy, but somewhat ligneous, and has numerous fibres. The stem is very short, round, simple, pubescent, generally bearing two leaves, from the axil of which the flower springs. The leaves are opposite, kidney-shaped, dark green, smooth and shining above, lighter and slightly hairy beneath, and stand on long footstalks. The flower is solitary, on a short peduncle, drooping, externally coriaceous and of a greenish brown colour, dusky purple within. The perianth (calyx) is persistent, campanulate, divided at the mouth into three pointed segments, which are inclined inwards. The stamens are twelve, rather short, situated on the germen; the filaments are produced beyond the cells of the anthers, as in Paris. The germen is inferior, 
the style short; the stigma has six radiated reflexed segments. The capsule is coriaceous, crowned by the persistent calyx, hexagonal, and divided into six cells, which contain numerous ovate seeds. Plate IV., fig. 2, (a) the flower viewed in front, shewing the stamens and six-parted stigma; $(b)$ stamens and pistils ; $(c)$ single stamen ; $(d)$ capsule cut transversely to show the six cells.

The Asarabacca is a native of most climates, from $60^{\circ}$ to $37^{\circ}$ North latitude. It is found in several parts of Great Britain, but is extremely local. It is abundant near Kirby Lonsdale, in Westmoreland, and in some other of the northern counties; it has also been met with near Maidenhead, in Berkshire, Kimbolton, in Huntingdonshire, and Linlithgow, in Scotland. It seems to prefer moist and shady situations, and exhibits its curious lurid flowers in May.

The ancient name Asarum, is said to have been formed from $\alpha, n o t$, and $\sigma \alpha \iota \omega$, to adorn, because it was rejected from the garlands of antiquity*. "It appears from Pliny," says Dr. Paris, " that the Asarum was not uncommonly confounded with the Baccharis (Baccharis Dioscorides, Willd.?); an English name was accordingly bestowed upon it, which is a curious compromise of the question, for it is a compound of both, viz., Asarabacca." It is provincially called Foal's-foot and Wild-nard.

QuAlities.- The fresh root of Asarabacca has a penetrating, aromatic odour, which is not unpleasant, and somewhat resembles that of valerian or nard. Both leaves and root are acrid, bitter and nauseous to the taste. The juice reddens litmus paper, and " a strong watery infusion of the leaves, which was of the colour of brandy, assumed a deep olive by the addition of sulphate of iron, and a greyish precipitate was thrown down." The aroma of the recent root appears to be owing to a volatile camphorated oil, which is not present in the dried root.

The Asarum Canadense, or wild ginger, is very nearly allied to the present species in botanical character, but is very different in its medicinal effects. The Canadian plant is a useful aromatic, and is devoid of the emetic principle which distinguishes the European Asarum; thus forming a striking exception to the general analogy which exists between the botanical and inedicinal character of vegetables.

" Plinii Hist. Nat. lib. xxi. cap vi. 
Medicat. Properties and Uses. - Both the leaves and root, in their recent state, are emetic and cathartic, and have been employed as a substitute for ipecacuanha. Dr. Gilibert says that ten grains of the fresh root powdered, make as good an emetic as ipecacuanha. He goes on to state, that judiciously administered, whether in powder, infused in water, or digested in white wine, it is an excellent remedy in intermittent fevers, obstructions of the liver and spleen, dropsies, and certain cutaneous diseases*. Notwithstanding these encomiums, it is seldom employed internally, and is principally used as an errhine. Being formed into a fine powder and taken as snuff, it occasions a most profuse discharge of mucus from the pituitary membrane of the nose, by which means head-aches, drowsiness, giddiness, and catarrhs, are often speedily and effectually relieved. It has also given great relief in certain species of deafness, arising especially from catarrhs. Geoffroy, who first learned its virtues from an English physician, found it extremely useful in his own practice. He gave from three to four or five grains to be snuffed up the nose going to bed. The use of it, contrary to that of most other snuffs, is not followed by sneezing, or any other immediate effect : but the following morning, a considerable quantity of serous discharge issues from the nose, which continues for some time, and, in some instances, even two or three days, with great relief to the patient.

Geoffroy relates a case of paralysis of the mouth and tongue effectually cured by a single dose of it. $\mathrm{He}$ recommends it strongly in heavy pains of the head, and all complaints attended with habitual drowsiness. Persons of full and plethoric habit, should, however, be very cautious in the use of this powerful errhine as it may act with dangerous violence on the vessels of the head. Exposure to cold during its use must be carefully avoided.

The powder of the root is much stronger than that of the leaves, and must consequently be taken in smaller quantity. Two grains are sufficient for a dose. The leaves however are

* He also asserts, that the root, after being kept six months, loses its emetic property, and is merely purgative; after two years this likewise disappears, and it is then diuretic. Another writer states, that, when finely powdered, it acts as an emetic, but when eoarsely powdered, it passes the stomach and becomes cathartic. 
to be preferred, and it will be necessary to use them in as recent a state as possible, as the acrimony, on which its properties depend, is lost with keeping; they should also be dried without the application of much heat, and when rubbed to powder, should be kept in bottles well stopped for use.

There is an elegant herb snuff, which, not long since, occupied a place in the London dispensatories, and is still retained in those of Edinburgh and Dublin, under the name of compound powder of Asarabacca. It consists of the following articles :-

Leaves of Asarum, three parts.

Flowers of Lavender, , of each one part.

Reduce them to a porder, which is to be preserved in close phials.

The famous powder of Sainte-Ange is composed of equal parts of the leaves of asarum, and the root of white hellebore; and some of the above ingredients, together with herb mastic, lily of the valley, or betony, constitute the cephalic and eye-snuff's that are daily advertised.

The leaves of asarum, on account of their resemblance to the shape of the human ear, were formerly employed in affections of that organ. For this purpose they were infused in water, which was dropped into the ear, or dried and used by fumigation. This absurd belief in the doctrine of signatures, was very prevalent in the fourteenth and fifteenth centuries. It was based on the following hypothesis, that every natural production indicates, by some obvious external mark, the diseases in which it is efficacious.

Thus the knotted root of the Scrophularia or figwort, was supposed to indicate its powcr over scrofulous tumours: the granulated root of the saxifrage, and the hard polished seed of the gromwell, were used in calculous and gravelly disorders : the spotted lungwort was exhibited in diseases of the lungs, and birthwort in those of the uterus. The root of the mandrake, from its supposed resemblance to the human form, was esteemed in the earliest ages a remedy for sterility*. Colours were also deemed typical of their properties; the bright yellow of the turmeric, indicated its efficacy in jaundice, and the scarlet of the poppy, a remedial virtue in erysipelas and hæmorrhages.

Many other instances might be adduced of this once popular doctrine, and which even now is not entirely exploded. Cowley and some other poets disfigured their verse with the wild conceit. 


\section{ix. \\ ASPARAGUS OFFICINALIS. \\ Common Asparagus.}

Class VI. Hexandria.-Order I. Monogynia.

Nat. Ord. Asphodelez.

Gen. Char. Perianth inferior, six-parted, deciduous.

Stigmas three. Berry globose, three-celled, few-seeded. Spec. Char. Stem herbaceous, erect, rounded, much branched. Leaves setaceous, fasciculate, flexible.

Greek.... à araparòs.

SYNONYMES.

Latin... \{ $\begin{aligned} & \text { Asparagus Sativa. Bauhin Pinax, } 489 ; \text { Ger. Em. } 1110 . \\ & \text { Asparagus. Raii. Syn. 267. }\end{aligned}$

French .. Asperge.

Asparagus Officinalis. Lin. Sp. Pl. 448.

Italian... Sparagio; Asparago.

Spanish.. Esparraguera; Esparrago.

German.. Spargel.

Dutch.... Spargie.

Polish.... Szparag.

Arabic... Yeramya.

Description.-The root is a collection of fleshy fibres, of a yellowish or ash colour, attached to a thick, hard, capitate, transverse stock. The stems are numerous, and appear in the spring under the form of young shoots, (turiones,) cylindrical, greenish, covered with scales, and terminating in a cone-like pointed bud; this expands as the season advances, and the stems attain the height of three or four feet. The leaves are linear, setaceous, soft, green, and disposed in fascicles of from three to five on the stem; at the base of each fasicle a very small membranous stipule is discovered. The flowers are drooping, greenish-yellow, and spring from the axils of the branches, either solitary or two or three together, on a pedicel articulated in the middle. The perianth is inferior, campanulate, and deeply divided into six segments. The six stamens are shorter than the periantl, and inserted into its base. The germen is three-cornered, surmounted by a short style, and a trigonal stigma. The fruit is a spherical berry, of a bright red colour, with three cells, each containing two hard, smootls, angular seeds. Plate II. fig. 2. $(a)$ the root; (b) the young stem; 
(c) the flowers; $(d)$ the calyx opened to show the stamens ; $(e)$ the fruit cut horizontally showing the cells.

The Asparagus is a denizen of most parts of Europe, having been observed in the sandy plains of Poland, on the banks of the Wolga, and even in Siberia. It is found in several parts of the south and south-west of England, especially near Kynance Cove, in Cornwall; and in the marshes about two miles from Bristol. It flowers in July and August.

The name appears to have been derived from the Greek

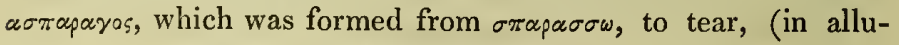
sion to the spines of some species,) and that, according to Theis, from spen, a spine, in Celtic.

The wild plant is much more diminutive than the cultivated variety. It is eaten by cows, goats, and sheep; horses and swine refuse it.

Culture. "Asparagus is generally grown in beds four feet broad, and in rows a foot or eighteen inches apart, by nine inches in the row. The plants are either raised from the seed where they are to remain, or raised on a seed bed the preceding year and transplanted. The value of the crop depends on the soil being dry, sandy, trenched two and a half or three feet deep, and powerfully manured. During winter the beds are covered with dung or litter to protect them from frost. In spring this is raked off into the alleys and dug in, while the beds are stirred with a fork to admit the air, heat, rain, \&c., to stimulate the rising shoots. Asparagus from seed will be fit to cut the third year, in perfection to the fifth, and will continue good for ten or twelve years. The season for cutting is from the middle of April to the middle of June." Loudon's Encyclopadia of Plants.

Qualities.-The uses of Asparagus as a culinary vegetable are well known. It was highly esteemed by the Greeks and Romans*. Cato and Pliny speak of it in the warmest terms of praise.

The roots have a sweetish and somewhat glutinous taste, with a little roughness : they give a slight tinge of red to blue paper. The juice of the young shoots has been found to contain wax, albumen, phosphate and acetate of potass, mannite, a green resin, and a crystalline principle, named asparagine. The crystals of asparagine are very slightly soluble in cold, rather more so in boiling water, and quite insoluble in rectified spirit.

Medical Properties and Uses. - Most persons perhaps have

* They boiled it so quickly, that to be done "sooner than Asparagus", became a proverb. Suetonius records that Augustus often said "Velociùs quam asparagi coquuntur." 
observed the powerful smell imparted to the urine immediately after eating the young shoots of asparagus. This circumstance, at an early period, directed the attention of physicians to its diuretic properties, which were found to exist to the greatest degree in the root. It is also gently aperitive, and may be employed to advantage in all obstructions of the viscera and derangements in the functions of the liver. It has been recommended in jaundice, and some other complaints connected with the abdominal viscera. Its sedative properties were discovered accidentally, by a gentleman labouring under palpitation of the heart, which he found diminished after eating asparagus. M. Eusebe de Salle has recently ascertained, that in addition it possesses the property of causing constriction of the throat and a spasmodic irritation of the larynx, which lasts about twenty minutes after its injection.

Vanhelmont and Etmuller, with some other of the old physicians, were of opinion that this plant assisted greatly the formation of calculus or stone in the bladder, and of gravel in the kidneys. Although there does not appear to be mucl foundation for this opinion, yet patients labouring under either of these complaints will do well to abstain from eating this plant, or any other that powerfully stimulates the urinary organs.

It has been ascertained by experiment, that the asparagine possesses the diuretic, and the green resin the sedative properties of the plant, but the combination of the two proves more efficacious: therefore the expressed juice, made into a syrup, will probably answer every purpose of the syrup of asparagine, which has been recommended in France.

Asparagine has been thus prepared by M. Regimbeau, of Montpellier :-

He has the stalks of Asparagus wrapped up in a piece of moistened linen for a few days at the ordinary temperature, until decomposition has com. menced, which may be known by the unpleasant smell. They are then beaten in a marble mortar, with a sufficient quantity of water to dilute the viscid juice, which is afterwards pressed strongly through a piece of cloth, and heated in order to coagulate the albumen and chlorophylle. It is subsequently filtered, and concentrated in a marine bath : it is again filtered and boiled down to the consistence of syrup, and set apart for a fortnight in a cool place. The vessel containing the liquid will be found lined with crystals of asparagine, covered with extractive matter: they are to be purifed hy washings in cold water or diluted spirit.-Journal de Pharmacie. 


\section{$\mathrm{X}$. \\ - GEUM URBANUM. \\ Common Avens, or Herb-Bennet.}

Class XII. Icosandria.-Order III. Polygynia.

Nat. Ord. Rosacere.

Gen. Char. Calyx ten-cleft; the alternate segments smaller. Petals five. Pericarps with long, geniculated awns. Receptacle elongated.

Spec. Char. Flowers erect. Cauline leaves ternate; radical ones lyrato-pinnate. Awns hooked, naked.

S Y NONYMES.

Latin .... $\left\{\begin{array}{l}\text { Caryophyllata. Raii Syn. } 253 . \quad \text { Ger. Em. } 994 . \\ \text { Caryophyllata vulgaris. Bauh. Pin. } 321 . \\ \text { Geum urbanum. Lin. Sp. Pl. 716. }\end{array}\right.$

French .... Benoite; Herbe de St. Benoit; Faliote; Recise.

Italian... Gariofillata ; Cariofillata; Erba Benedetta.

Spanish.... Gariofilata; Gariofilea.

Portuguese.. Gariofillata.

German..... Benediktenkraut; Nelkenwurzel.

Dutch...... Nagelkruid ; Gezegent kruid.

Polish .... Zarzycka.

Swedish... Neglikerot.

DEscription.-The root is 'perennial, woody, and fibrous. The stem is erect, branched toward the top, somewhat angular, hairy, reddish at the base, and attains the height of nearly two feet. The radical leaves are on long channelled footstalks, winged' with several unequal serrated leaflets, 'the terminal one very large, rounded, toothed, and generally three-lobed; the cauline ones are alternate, three-lobed, or trifid, nearly sessile, and have two incised stipules at the base; the whole are hairy and of a deep green colour. The flowers are terminal, pedunculated, and somewhat drooping. The calyx is half divided into ten pointed segments, the five alternate ones smaller than the rest. The five petals are entire, spreading, unguiculate, nearly round, and of a bright yellow colour. The stamens are numerous; the 

flancuts awl-shayed, attaclied to the calyx; the anthers globose. The germens are numerous, superior, compressed; the styles long, hairy, and terminated by simple stigmas. The receptacle is elongated, hairy, and surmounts the persistent reflexed calyx. The pericarps are crowded upon the receptacle; they are small, unilocular, one-seeded, and each tipped with a rigid purple awn, (the persistent style,) which is curved at the extremity. Plate IV. fig. 1. (a) the calyx, stanens and pistils; (b) a single pericarp.

This plant is frequent in woods and hedges throughout Great Britain in shady situations, and is found in most parts of Europe, as far north as Sweden. It flowers in June and July.

The generic name Geum is derived from rava, to yicld an agrecable flavour, in allusion to the roots. Hence also the term Caryophyllata from Caryophyllus, a clove. It is called HerbBennet, from the name of the patron Saint Benedict; and Avens, from aveo, to rejoice. Cows, goats, sheep, and swine eat it: horses are not fond of it.

Qualities and general Uses.-The root dug up in the spring has an aromatic odour, resembling cloves, which is soon lost. The flavour is aromatic, combined with a peculiar bitterness, and subsequently an astringent taste. The watery infusion reddens litmus paper, and strikes a black colour witl sulphate of iron. Submitted to analysis, it yields a large quan.tity of mucilage and astringent principle, tannin, aromatic resin, and a portion of muriate of lime. By distillation in water a small portion of heavy volatile oil is obtained.

The roots of Avens are applied to the following domestic purposes. $\Lambda$ small quantity put into ale, gives it a fine flavour and perfume, and prevents it from turning sour. The young leaves are sometimes eaten in salads; and the roots are used to $\tan$ leather, and to dye wool of a perminent dark yellow colonr.

Medical Properties and Uses.-I'lhe root of Avens is astringent, tonic, and antiseptic, but it is undeservingly neglccted in modern practice. It has been highly extolled by some of the continental plysicians in the cure of intcrmittent fevers. An infusion of two drachms of the root * sliced in half a pint

- The roots should be dug up early in the spring, and those plants should be preferred which grow in dry and warm situations. They are to be drierl gradually, then sliced or powdered, and kept in well stopped ressels. 
of white wine for two hours, taken at the commencement of the cold fit, will cut short the paroxysm, and the powder of the root has been employed successfully instead of the Peruvian bark, in the dose of a drachm every two hours. In continued fevers it is an excellent cordial sudorific, in the dose of ten grains of the powder, or a wine-glassful of an infusion made by pouring a pint of boiling water on half an ounce of the dried root sliced; this should stand till it is cold, and then be strained off, not too nicely. In diarrhœas, dysenteries, and particularly those loosenesses which often succeed to fevers and other acute diseases, this is an invaluable remedy.

The decoction is much stronger than the infusion, but not so grateful : it may be made with one ounce of the root to a pint and a half of water, boiled down to two-thirds and then strained; which is to be taken by glassfuls.

The simple tincture is thus made :-

Take of Root of Avens, one ounce.

Rectified Spirit, half a pound.

Macerate for several days in a close vessel. Dose half an ounce, three times a day.

\section{COMPOUND TINCTURE OF AVENS.}

Take of Avens root, bruised, an ounce and a half;

Angelica root, bruised,

Tormentil root, bruised, of each an ounce ;

Jar raisins, stoned, two ounces ;

French brandy, two pints.

Macerate for a month, in a warm place, then filter through paper. It is stimulant.-Dose half an ounce.

The extract has been recommended in cases of extreme irritability of the stomach, where no medicine can be retained but in very small quantity.

\section{EXTRACT OF AVENS.}

Take of Root of Avens, one part.

Water, eight parts.

Macerate for twenty-four hours; then boil for a quarter of an hour and express strongly. Let the residue be boiled with four parts of water. Mix the two decoctions and set the liquor aside for twenty-four hours : finally evaporate to a proper consistence.

This extract may be given in the form of pills, in doses of from five to ten grains. 



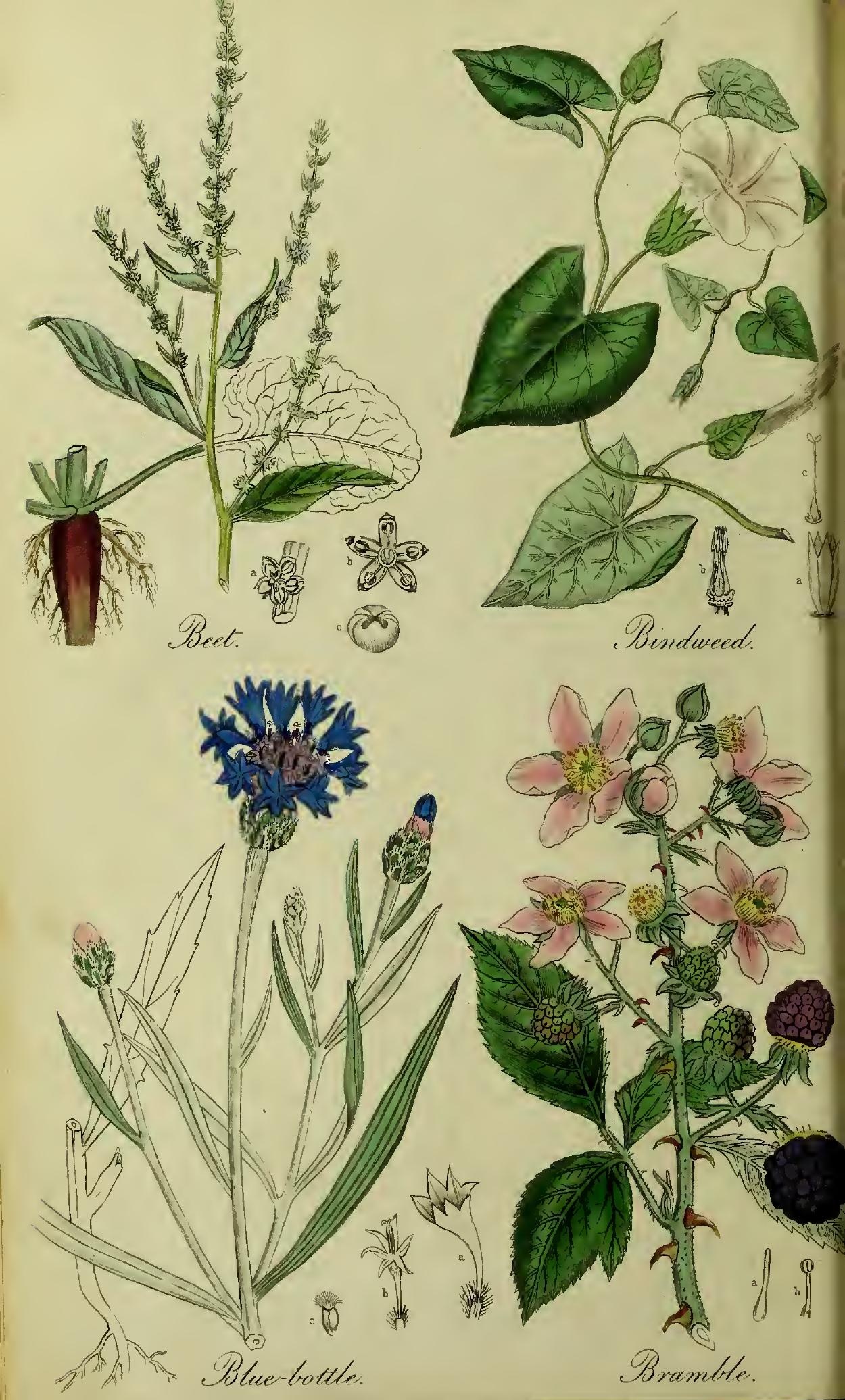


XI.

\section{MELISSA OFFICINALIS.}

\section{Common Balm.}

Class XIV. Didynamia.-Order I. Gymnospermia.

\section{Nat. Ord. Labiate.}

Gen. Char. Calyx dry, nearly flat above; the upper lip somewhat fastigiate. Corolla upper lip somewhat vaulted, bifid; lower lip smaller, with the middle lobe cordate.

Spec. Char. Whorls halved, subsessile. Bracteæ oblong, stalked. Leaves ovate, acute, serrated.

\section{SYNONYMES.}

Greek .... $\mu \varepsilon \lambda \iota \sigma \sigma o ́ \varphi \nu \lambda \lambda \circ$. Dioscorides.

Latin .... $\begin{aligned} & \text { Melissa. Gerard Em. 689. Raii Hist. } 570 . \\ & \text { Melissa hortensis. Bauhin Pinax, } 229 . \\ & \text { Melissa officinalis. Lin. Sp. Pl. 827. }\end{aligned}$

French.... Melisse ; Citronelle ; Citronade.

Italian.... Melissa ; Cedronella.

Spanish.... Melisa; Cidronela.

Portuguese. Melissa.

German.... Melisse; Citronen-Melisse; Citronenkraut.

Dutch..... Melisse; Citroenkruid.

Swedish.... Meliss.

Polish.... Melisa.

Description.-The roots are slender, cylindrical, somewhat branched, and fibrous. The stems are annual, quadrangular, nearly smooth, much branched, and rise from one to two feet in height. The leaves are opposite, petiolate, ovate, the lower somewhat cordate, serrate, of a bright green colour, and clothed with short hairs. The flowers are small, numerous, axillary, arranged in semi-whorls, on slender peduncles, and furnished with several small oblong bracteæ at the base. 'T'he calyx is pen- 
tangular, striated, the upper lip tridentate; the lower shorter, and cut into two acute teeth. The corolla is white, yellowish, or flesh-coloured, bilabiate, somewhat inflated at the throat; the upper lip somewhat vaulted, rounded, bifid; the lower witl three lobes, the central one nearly round. The stamens are four, inserted into the corolla, two of them shorter, furnished with roundish anthers. The germen is deeply four-lobed, with a simple style, terminated by a bifid stigma. The fruit consists of four small nuts, irclosed within the persistent calyx. Plate II. fig. 4. (a) the flower seen in front; $(b)$ the same viewed sidewise; (c) the tube of the corolla, opened to show the stamens; $(d)$ the ripe fruit.

This plant is a native of the South of Europe, growing in hedges and on the borders of woods. It is not indigenous to this country, but has been cultivated in gardens from time immemorial, and is generally well known. It is perennial, and flowers from June to September.

It derives the name by which it is distinguished in most European languages, from the Greek, $\mu^{\prime} \lambda_{i} \sigma \sigma \alpha, a$ bec; because of the fondness of bees for its flowers.

Qualities.-The leaves of this plant have an agreeable aromatic odour, resembling that of lemons; which is most perceptible just before flowering*, and is almost lost in drying. They are slightly aromatic and bitter to the taste. Its odour depends on a volatile oil, which it yields in distillation with water. It_also contains a bitter principle, which is slightly soluble in water, and appears to be of the nature of gum resins. The watery infusion slightly reddens litmus paper, and affords a deep brown with nitrate of silver.

Medical Properties and Uses.-Bälim has tonic, cephalic, cordial, and stomachic properties. It was first used by the Arabs to strengthen the nerves and to promote cheerfulness. "It acts as a tonic upon the stomach, increases the appetite, and facilitates digestion; its secondaiy effects are to auginent the circulation, the secretions, and nutrition; hence it has obtained the titles of stimulant, diuretic, diaphoretic, and emmenagogue." It is trequently employed, more or less successfully, in vertigo,

* This indicates the time at which the herb should be gathered for meriicinal purposes. 
syncope, paralysis, asphyxia, \&c., and is recommended by Hoffman in hypocliondriasis; by Riviere in mania, and by Forestus in palpitations of the heart. In certain cases of obstructed menses it has been singularly efficacious. This aromatic plant must not, however, be administered in diseases which are attended with acute pain, much heat and thirst, and other signs of irritation.

Its virtues as a sudorific are well known to the country people, who make it into tea, which is drunk freely in hysteric affections, head-acles, and indigestions. A conserve is sometimes made, which is taken in doses of two drachms or more. The essential oil is given in the quantity of one to four drops upon sugar, and the distilled water from one to four ounces.

There is a compound spirit of Balm, which formerly enjoyed great reputation, and deservedly so, under the name of Eau des Carmes, or Carmelite water; it was prepared thus :

Take of fresh leaves of Balm fuur ounces;

Outer rind of Lemon, fresh (grated) two ounces ;

Nutmegs, and Coriander Seeds, of each one ounce;

Cloves, Cinnamon, Angelica Root, of each half an ounce;

Having bruised the leaves and pounded the other ingredients, put them with a quart of brandy into a glass retort, stop the mouth and set it in a warm place for two or three days. Add then a pint of simple Balm water, and shake the whole well together; after this distil in a sand-bath, till the ingredients are left almost $d r y$, and preserve the spirit in bottles well stopped. 
XII.

\section{BERBERIS VULGARIS.}

\section{Common Barberry.}

\section{Class VI. HeXandria.-Order I. Monogynia.}

Nat. Ord. Berberides.

Gen. Char. Calyx of six concave leaves, coloured, inferior, deciduous. Petals six, each with two glands at the base. Berry one-celled, two to three seeded. .

Spec. Char. Racemes pendulous. Spines three-forked. Leaves simple, obovate, ciliate-serrate.

S S Y N O Y M E S.

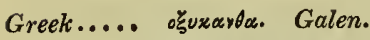

Latin.... \{ $\begin{aligned} & \text { Spina acida sive Oxyacantha. Gerard Em. 1144. } \\ & \text { Berberis dumetorum. Bauhin Pinax, 454. Raï Syn. } 465 . \\ & \text { Berberis vulgaris. Lin. Sp. Pl. 471. }\end{aligned}$

French.... Berberis; Epine-vinette; Vinettier.

Italian... . Berberi; Berbero; Crespino ; Trispina.

Spanish.... Berbero; Berberis.

German.... Berberstrauch; Sauerdorn; Saurach; Berberis.

Dutch..... Berberis; Barbarisse; Zuurdoorn.

Swedish.... Berberis.

Arabic...... Berberys.

Description.-The root is woody, creeping, branched, and of a yellowish brown colour. The stems are erect, and attain the height of six or eight feet; the branches are diffuse, covered with a smooth greyish bark, and furnished at each joint with acute spines, generally three in number. The leaves are arranged four or five together on the branches; they are inversely ovate, ciliato-serrate, smooth. The flowers spring from the axils of the leaves in simple, pendulous, elongated racemes. The calyx is inferior, deciduous, and of a greenish yellow colour, consisting 
of six ovate, concave, obtuse leaves, three of them alternately smaller, and is furnished with three bracteæ at the base. The corolla is composed of six concave rounded petals, of a bright yellow colour, with two glands at the base of each. The stamens* are six in number, opposite the petals, and tipped with bifid anthers. The germen is simple, cylindrical, and terminated by a large, sessile, depressed stigma. The fruit is an ovoid, cylindrical berry, a little curved, bright red, tipped with the black style, and containing two oblong seeds. Plate II., fig. 3. (a) cluster of fruit ; (b) corolla and stamens; (c) calyx and pistil; $(d)$ berry cut lengthwise to show the seeds.

The Barberry is a hardy shrub, growing in nearly all temperate climates. It is found in woods and hedges in many parts of England and Scotland, and near Fermoy in Ireland. It flowers in June.

The name is said by Théis to have been borrowed by the Romans from the Arabic word Berbêrys. It is called provincially, Pipperidge-bush.

Qualities and general Uses.-The juice of the fruit is austere and very acid; it stains blue paper of a deep red colour: its acid is the oxalic. The roots boiled in a ley yield a yellow colour, which is used to dye wool, cotton, and flax, and is also employed by cabinet-makers and curriers; the inner bark of the stem, with the assistance of alum, affords a yellow dye. The leaves are gratefully acid; they are said to be eaten by kine, goats, and sheep, but refused by horses and swine. The flowers emit an unpleasant smell when near, but at a moderate distance their odour is very agreeable. The ripe fruit forms a well known preserve. The unripe berries may be pickled in the same manner as capers.

The Barberry is an object of dislike to the farmer, on account of its reputed baneful effect upon corn. Ir. Withering says, "this shrub should never be permitted to grow in corn lands, for the ears of wheat that grow near it never fill, and its influence in this respect has been known to extend as far as three or four hundred yards across a field." Nevertheless, this assertion has met with many strenuous opponents. Sir J. Banks supposes,

- The stamens exhibit a remarkable degree of irritability. When touched at the base by the point of an instrument, they rapidly approach the pistil, and if the anthers are fully ripe, the pollen is exploded. Wher put into water or solution of gum, the flowers may be preserved for several days, possessing their irritability. 
that the Ecidium Berberidis, an insect which generally infests the shrub, generates the dust, which, carried away by winds, and lighting on wheat and other growing corn, gives rise to the Puccinia, a minute fungus, which closes up the pores of the leaves and appears like rust or mildew.

Medical Properties and Uses. - The bark and fruit of this plant are used in medicine; the former is extolled in diarrhœas and dysenteries; the latter, on account of their grateful acid juice, furnish a very pleasant and serviceable beverage in fevers, bilious disorders, and scurvy. The fruit is variously prepared; it may be made into comfits, syrup, jelly, or jam. These different preparations may be employed in forming drinks, which in all kinds of inflammatory diseases, scalding of urine, and especially typhus fevers, are taken with the greatest advantage. Prosper Alpinus attributes his recovery from the plague to following the advice of the Egyptian physicians, who gave him no other medicine than the syrup of Barberries with the addition of a small quantity of fennel seed. Simon Pauli followed with success the same advice in a malignant fever and diarrhœa, with which he was attacked in Paris, which induced him to recommend very strongly in his works the different preparations of this plant.

The juice may be thus prepared :-

Take of ripe Barberries, any quantity;

Bruise them in a mortar, and set the mass aside for sereral days in a cool place ; then express the juice and leave it as before : strain it, pour it into long necked bottles, cover it with a stratum of oil and keep it in a cellar.

SYRUP OF BARBERRIES.

Take of expressed and filtered juice of

Barberries................. one pilut.

White Sugar .............. one pound and a half.

Boil them together and strain.

An excellent gargle for sore throats may be made with this syrup.

The inner bark infused in white wine is said to be purgative, and Ray experienced its good effects in jaundice. 
XIII.

ARBUTUS * UVA URST.

Bearberry.

Class X. Decandria.-Order I. Monogynia.

Nat. Ord. ERices.

Gen. Chıp. Calyx deeply five-cleft. Corolla ovate, with a five-cleft orifice; pellucid at the base. Berry superior, five-celled, many-seeded.

Spec. Char. Stems procumbent. Leaves obovate, entire, evergreen. Racemes terminal.

SY NON Y M ES.

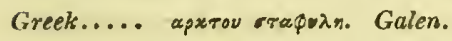

Latin ..... $\begin{aligned} & \text { Vaccinia ursi, sive Uva ursi apud Clusium. Ger. Em. } 1416 . \\ & \text { Vaccinia rubra foliis myrtinis crispis. Raii Syn. 457. } \\ & \text { Vitis idca foliis carnosis et veluti punctatis. Bauh. Pin. } 470 . \\ & \text { Arbutus Uva Ursi. Lin. Sp. Pl. } 566 .\end{aligned}$

French.... Busserole; Raisin d'ours ; Arbousier trâinant.

Italian.... Uva d'orso; Uva orsina.

Spanish.... Gayuba; Uva de oso.

Portuguese Uva de urso.

German ... Beerentraube; Steinbeere.

Dutch .... Beeren-druif; Wolfs-bezien-boomtie.

Swedish ... Miolon; Miœlbœr.

Danish.... Miœluebœr.

Description.-The root is perennial, long, branched, and fibrous. The stems are numerous, long, procumbent, spreading, branched, smooth, and covered with deciduous bark: the young shoots are tinged with red, and slightly pubescent. The leaves are inversely ovate, obtuse, entire, stiff, rigid, glabrous, evergreen, revolute at the margin, marked with reticulated veins beneatl, and attached to the stem by short petioles. The flowers terminate the branches in small crowded racemes, with several bracter at the base. The calyx is very small, five-cleft, obtuse, persistent. The corolla is ovate, pellucid at the base, contracted towards the mouth, and divided into five reflexed rose-

\footnotetext{
- Arctostaphylos of some writers.
} 
coloured segments. The stamens are ten in number, about half as long as the corolla, and inserted into its base; the anthers are two-celled, and furnished with two horn-like appendages. The germen is ovate or globose, superior, seated on a glandular disk, and bears a cylindrical erect style, terminated by an obtuse stigma. The fruit is a small, spherical, depressed berry of a deep red colour, containing an austere mealy pulp, and five cells, in each of which is lodged a hard brown seed. Plate III., fig. 4. (a) cluster of ripe fruit ; (b) corolla opened, to show the stamens; $(c)$ stamen; $(d)$ berry cut horizontally, to show the cells.

This hardy evergreen shrub is widely diffused over the globe, being equally abundant under the genial skies of France and Spain, and the inhospitable climate of Lapland. In North America, it grows from Hudson's-bay to the central parts of the United States. It is found in the North of England and Ireland, and is especially frequent in the Highlands of Scotland. It prefers alpine, heathy, and rocky places, and often covers the ground with beds of considerable extent. It flowers in May.

It derives its Latin name according to Théis, from ar, rough, and boise, a bush, in Celtic.

Horses, cows, goats, and sheep refuse it, but the berries afford an excellent food for the moor-fowl.

Qualities.-The Bearberry has no remarkable odour in any of its parts. The leaves are at first austere to the taste, and have a slight bitterness, which is not unpleasant. When dried and reduced to powder, they have a fragrant snell, and are far more bitter than when recent. The bark is more astringent and less bitter, while the wood is almost insipid. The berries are nearly tasteless, but leave behind a slight degree of astringency.

Both water and alcohol extract the virtues of the leaves, and the watery infusion takes a deep black colour on the addition of sulphate of iron. Chemical analysis has shewn that they contain a large proportion of tannin, and Linnæus* states, that great quantities of the leaves and branches are gathered in the north of Sweden and sent to Stockholm, where they are bought by tanners, for the same purpose as the sumach (Rhus Coriaria). They are also used to dye wool.

* Flora Lapponica, p. 130. 
Medical Properties and Uses.-This plant, though known to the ancient physicians, and occasionally employed by them, was first brought into notice in the middle of the last century by De Haen, as a valuable medicine in cases of stone and gravel, and ulcerations of the urinary organs. It has since been found to possess very considerable medical properties, and employed with great success in excessive menstruation, gonorrhœa, diabetes, and in almost every disease connected with the urinary organs. Drs. Ferriar and Bigelow speak favourably of its action in nephritis, or inflammation of the kidneys, brought on by gravelly concretions. They add, the use of it ought generally to be preceded by evacuations.

A few years ago, the Uva Ursi was strongly recommended by Dr. Bourne of Oxford, in pulmonary consumption. He found it of considerable efficacy in diminishing hectic fever, and abating the frequency of the pulse connected with that disease.

The dose of the powdered leaves is from a scruple to a drachm, two or three times a day. The decoction may be made with half an ounce of the leaves, boiled for ten minutes in a pint of water, of which a wine-glassful may be taken every hour.

For medical purposes, this plant should be procured in autumn; the green leaves alone selected, picked from the twigs, and dried by exposure to a moderate heat. 


\section{XIV.}

\section{ACANTHUS MOLLIS.}

Smooth Bear's-Breech.

Class XII. Didynamia.-Order II. Angrospermia.

Nat. Ord. Acanthaceer.

Gen. Char. Calyx four-parted; the two lateral inner segments short; the two outer long, with three bracteæ, of which the middle one is toothed, spiny. Corolla labiate, the orifice closed with hairs; lower lip large, three-lobed. Stigma bifid. Capsule ovate; cells with one or two seeds.

Spec. Char. Leaves sinuated, unarmed.

S Y NON Y MES.

Greek..... $\alpha$ aravos.

Latin.... $\left\{\begin{array}{l}\text { Acanthus. Ger. Em. 1147. Raii Hist. } 1326 . \\ \text { Acanthus Sativus. Bauhin Pinax, } 383 . \\ \text { Branca Ursina. Murray, 204. } \\ \text { Acanthus Mollis. Lin. Sp. Pl. 891. }\end{array}\right.$

French.... Acanthe; Branche-Ursine.

Italian... A Acanto; Brancorsina ; Branca Orsina.

Spanish ... Acanto; Garra Ursina; Yerba Giganta.

Portuguese. Acanto.

German ... Bärenklaue.

Dutch .... Beerenklaauw.

Danish... Bronekloe.

Description.-The root is long, thick, fleshy, diffuse, fibrous, of a dark colour externally, and nearly white within. The stem is cylindrical, upright, simple, firm, from two to three feet in height, and clothed with flowers from the middle to the summit. The leaves are nearly all radical, amplexicaul, very long, smootl, soft, sinuated, and pinnatifid, with many angular clefts. The flowers are arranged in a long spike at the top of the stem. The calyx consists of four unequal leaflets, somewhat 
labiate, persistent. The corolla has but one lip, which is monopetalous, ample and plane, closed with hairs at the orifice, and divided into three lobes at the extremity; the place of the upper lip is usurped by the calyx. The stamens are four, didynamous, with villous anthers. The germen is seated on a disk, and is two-celled, supporting a simple style and a bifid stigma. The fruit is a capsule of two cells, opening elastically with two valves; each cell containing a single roundish seed. Plate 3, fig. 3, (a) the corolla, stamens, and pistil ; (b) the pistil; (c) the capsule.

This very elegant plant delights in warm countries, such as Italy, Egypt, the Levant, and the south of France; growing in moist, stony places, and on the banks of large rivers. Although not a native, it is generally known and admired in the English garden, where it has occupied a place since the commencement of the sixteenth century. It is a perennial herbaceous plant, and flowèrs from July to September.

The generic name derived from $\alpha x a v \uparrow \alpha, a$ spine, does not apply to this species, which is smooth and unarmed; nevertheless it is the Acanthus, par excellence,-the plant celebrated by Virgil and other poets. It has been renowned for ages, on account of the beauty of its leaves, which furnished the ancient sculptors and architects with one of their chief ornaments. The Greeks and Romans carved them upon their vases, and their massive goblets*, and wove them into their costly vestments $\downarrow$. The discovery of their ornamental character is contained in the following legend :

"A young lady of Corinth, having died a few days before her marriage was to have been celebrated, her aflicted nurse put into a basket different articles of which the girl was fond, and placing it near her tomb, upon a plant of the Acanthus, covered it with a large tile. The following spring the Acanthus grew up, and its large leaves encompassed the basket; but meeting with the projecting tile, they were curved at the extremity and bent down. An architect named Callimachus passing by, was struck witl the novelty and beauty of the figure, and resolved to apply it to the decoration of the Corinthian capital."

- Et nobis idem Alcimedon duo pocula fecit, Et molli circum est ansas amplexus acantho.

Summus inaurato crater elat asper acantlio.

Virgil. Ec. iii. l. 45.

Ovid. Mel. lib. xiii. l. 701.

+ Et circumtextum croceo velamen acantho.

Virgil. SEn, Lil. i, 649. 
Milton enumerates this among the plants which decked the primeval bowers of Eden,-

$$
\text { " on either side }
$$

Acanthus, and each odorous bushy shrub

Fenced up the verdant wall."

Medical Properties and Uses.-The reputation of this plant as a medicine has much declined in modern days. It was formerly reckoned one of the five emollient plants, and prescribed in cataplasms, fomentations, and lavements, to mitigate inflammatory or nervous irritation. It acts as a slight astringent in hæmoptysis or spitting of blood, diarrhœas and dysentery.

The leaves, boiled and mashed up into a poultice, have been recommended as an application to deep-seated abscesses, for the purpose of hastening suppuration. The roots abound in mucilage, and may be substituted for those of comfrey and marshinallow. 


\section{XV.}

\section{HELLEBORUS FATTIDUS.}

Bear's-Foot, Stinking Hellebore, or Setter-mort.

\section{Class XIII. Polyandria.-Order III. Polygynia.}

Nat. Ord. Ranunculaces.

Gen. Char. Caly $x$ of five persistent leaves. Petals eight to ten, small, tubular, two-lipped, nectariferous. Pericarps or follicles nearly erect, many-seeded.

Spec. Char. Stem many-flowered, leafy. Leaves pedate; segments oblong-linear. Calyx converging.

S Y N O Y M E S.

Helleborus niger fotidus. Banh. Pin. 185.

Latin .... Helleboraster maximus. Ger. Em. 976. Raii Syn. 271.

(Helleborus foetidus. Liv. Sp. Pl. 784.

French.... Ellebore fetide; Pied de griffon.

Italian.... Elleboro fetido.

Spanish .. Eleboro hediondo.

German .. Stinkende Niesewurz.

Duti.h .... Stinkend Nieskruid.

Description.-The root is small, twisted, and beset with numerous, slender, dark-coloured fibres. The stem is cylindrical, firm, naked, leafy, marked with cicatrices* towards the base, much branched, many-flowered, and rises to the height of two feet. The leaves stand on long footstalks; they are dark green, coriaceous, smooth, digitate or pedate, with numerous pointed, serrated segments. The bracter or floral leaves are membranous, entire at the margin; the lowermost trifid at the extremity, and tinged with purple at the base; the upper ones nearly ovate, undivided, and of a pale green colour. The flowers are numerous, terminal, somewhat panicled, drooping,

* These cicatrices or scars are produced by the falling of the old leaves. 
globose, and stand on long peduncles. The calyx is pale green, composed of five ovato-cordate persistent sepals, tinged with purple at the margin. The petals* are from eight to ten in number, small, tubular, two-lipped, nectariferous at the base, and arranged in a circle within the sepals. The stamens are very numerous, as long as the calyx, with whitish anthers. The germens are usually three, superior, ovate, compressed; styles subulate; stigmas globose. The fruit consists of three or four follicles, which contain numerous oval seeds, disposed in two rows. Plate 6, fig. 4, (a) the stamens; $(b)$ the follicles.

This evergreen perennial plant grows in chalky pastures, thickets, and way-sides, in most parts of western Europe, viz. Portugal, Spain, Italy, Switzerland, France, and Germany. It has been found near Castle-Acre, Norfolk, and in several other English counties; by the Doune, Ayr, also at Blantyre, Barncluish, and near Anstruther, in Scotland; but can scarcely be considered indigenous. It flowers in March and April.

The name of the genus is derived from $\varepsilon \lambda \varepsilon i v$, to injure, and Bog $\alpha$, food, indicative of its poisonous properties.

Qualities. - The recent plant has a most fetid odour and bitter taste, and is extremely acrid, excoriating the mouth and fauces when chewed. The bracteæ are said to possess these qualities in a greater degree than the proper leaves. Like the other plants of the natural order to which it belongs, its virtues are much impaired by age and by the mere process of drying.

The root of this plant is used as a seton in veterinary practice. For this purpose a perforation is made in the flesh of the animal, and a piece of the root being inserted, is left for twenty-four hours; this causes a discharge from the part, and is thought to be efficacious in certain diseases. Hence, in all probability is derived the provincial name Setter-wort, or Settergrass, corrupted from Séton-wort.

Poisonous Properties. - This species of Hellebore is more eminently poisonous than the Helleborus niger, producing in an over-dose superpurgation, griping, anxiety, syncope, violent pain in the stomach and intestines, a sensation of strangling, coldness of the extremities, convulsions, and death. The leaves 
are not unfrequently employed by empiries and ignorant persons, and instanees are not wanting of their fatal effects.

In the Oxford Magazine for 1769, it is related that a labouring man gave some of this plant to his two sons, one six, the other four years old, to kill worms, and in a few hours tley both died. It is also mentioned that those who have taken a poisonous dose and recovered, have lost their hair, nails, and even the epidermis of the whole body. In the London Chroniele for 1768, No. 1760, we read that a ehild lost its life from taking some of the root in the pulp of an apple.

This being elassed among the narcotico-acrid poisons requires nearly the same antidotes as the Aeonite, Arum, \&c. In the first place, vomiting must be excited and eneouraged, if it has not spontaneously commeneed. "If the poison has been some time ingested, an emetic combined with a eathartic should be administered, eomposed of two or three grains of emetie tartar and an ounee of Epsom salts. Purgative clysters ought also to be administered. If apopleetic symptoms appear, bleeding or the application of leeches is advisable. Acidulated drinks should afterwards be employed, and especially vinegar and water in small doses, frequently repeated. To combat the inflammation, whieh almost invariably sueeeeds, the aeidulated drinks should be replaced by emollient infusions and decoctions, such as the infusion of marsh mallows or violets, or a solution of gum arabie. The applieation of a few leeches to the abdomen may likewise be serviceable." Orfila.

Medical Properties and Uses.-The leaves of this plant were used in this eountry as a domestic medicine for their vermifuge effects long before their introduction into the London Pliamacopœia. Gerard thus alludes to them :

"The leaves of bastard Hellebor, dried in an oven, after the bread is drawne out, and the powder thereof taken in a figge or raisin, or strawed upon a piece of bread spread with honey, and eaten, killeth worms exceedingly."

Dr. Bisset states, that in Yorkshire the peasantry often give it to their children when they suspeet them to have worms. "The deeoction of about a drachm of the green leaves, or about fifteen grains of the dried leaves in powder, is the usual dose administered to ehildren between four and seven ycars of age. A full or suffieient dose generally proves more or less emetie, and often loosens the belly a little. It is ustually repeated on 
two and sometimes three successive mornings. The second dose has commonly a greater effect than the first, and never fails to expel round worms by stool, if there be any lodged in the alimentary canal."

For children a syrup has been recommended, made with the expressed juice of the recent leaves moistened with vinegar, which is supposed to correct the violent effects of the drug. The dose of this syrup is a tea-spoonful at bed-time, and one or two in the morning, on two or three successive days, for young children, increasing or diminishing the quantity according to the strength of the patient. Dr. Parr mentions that a tincture is sometimes made of the leaves with cyder, but in whatsoever manner prepared, no medicine acts with more certainty as anthelmintic, than Bear's-foot.

It has also been highly extolled in epileptic fits caused by the presence of worms in the intestines, and in astlima and lypochondriacal disorders, but it is a dangerous medicine in unskilful hands, and requires to be used with the greatest caution. 
XVI.

\section{BETA VULGARIS.}

\section{Common Beet.}

\section{Class V. Pentandria.-O Order II. Digynia.}

Nat. Ord. Chenopodee.

Gen. Chak. Perianth single, half-inferior, five-cleft, persistent. Seed one, reniform, imbedded in the fleshy calyx.

Spec. Char. Flowers clustered. Lower leares ovate. Root fleshy.

S Y N ON Y M E S.

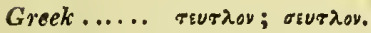

Latin .... $\left\{\begin{array}{l}\text { Beta rubra vulgaris. Bauh. Pin. } 118 . \\ \text { Beta rubra romana. Ger. Em. } 319 . \\ \text { Beta vulgaris. Lin. } S p . P l, 322 .\end{array}\right.$

French.... Bette; Betterave.

Italian .... Bieta; Barbe brettola.

Spanish.... Acelga ; Remolacha.

German.... Beete ; Rothe rübe ; Mangold.

Dutch..... Beet; Biet.

Polish..... Cwilka.

Russ. ..... Swekla.

Description. - The root is biennial ; fusiform, fleshy, slightly branched, and furnished with numerous capillary fibres. The stem is upright, leafy, channelled, smooth, branched towards the top, and rises to the height of three or four feet. The leaves are alternate, and vary in figure according to their position; the lower ones are large, somewhat cordate, and obtuse ; as they approach the top of the stem they become narrower and pointed, and almost destitute of petioles; they are all bright green, smooth, and succulent. The flowers are disposed three or four together, on long slender spikes, which spring from the axils 
of the upper leaves. The perianth (calyx) is single, persistent, deeply five-cleft, and slightly adherent by its base to the germen. The five stamens are short, opposite the divisions of the calyx, and support roundish anthers. The germen is globose, depressed, surmounted with two short styles, terminated by simple acute stigmas. The seed is solitary, kidney-shaped, imbedded in the fleshy mass of the calyx, which serves as a capsule. Plate 5, fig. 1, (a) the aggregated fruit; (b) the flower; (c) an isolated fruit surrounded by the persistent calyx.

The Common Beet grows naturally in many southern and temperate climates, especially in maritime places, but is not indigenous to this country. The Beta maritima which grows on our sea-slıores, is easily distinguished from this species by its procumbent stems and flowers in pairs. It flowers in August.

The name is said by Théis to be derived from the Celtic bett, which signifies red. Others imagine it to have been formed from the Greek $\beta$, on account of a fancied resemblance of its seeds to that character.

Cucture. - " There are several varieties; those most esteemed for salads are the small red and Castelnaudary, and for extracting sugar, the green-topped. The seed is sown in March or April, on deep well comminuted soil. When then the plants show two or three proper leaves, they are thinned out, so that each plant may be allowed a square foot of surface. By September or October, the roots are fit for use, and may either be taken up as wanted, or buried in sand in the root.cellar."Loudon.

The white beet (beta cicla) Poirée à cardes, Fr.; Bietola, It. ; is used for nearly the same purposes as the red. In many parts of the continent, the leaves deprived of their midrib are used as spinach, or put into soups, and the midrib is boiled and eaten as chard or asparagus.

Qualities and General Uses. - The common Beet is a well known culinary vegetable, extensively used as a pickle and salad *; preserved as a confiture, made a substitute for coffee, and yielding a beautiful varnish. A good beer may be made from the roots, and when fermented, a pleasant wine. Submitted to the acetous fermentation, and reduced to a pulp,

* The poct Martial notes its insipidity :-

"Ut sapiant fatur fabrorum prandia betx, O quam sæpe petet vina piperque coquus !" 
the beet-root is the principal ingredient in the substance named barszcz, in Poland, which is estcemed a salubrious food, and a preservative against scurvy and putrid fevers.

But the most important product of this plant is the saccharine matter which is procured so abundantly from the roots, and which may rival that obtained from the cane. The extraction of sugar from beet-root, first resorted to by Buonaparte as a matter of necessity, has been carried to such perfection in France as to become a lucrative branch of commerce; and the people of that country appear to be sanguine of rendcring themsclves independent of the colonies for that important article at no very distant period. The following is a good but not a very profitable way of preparing it.

"Let the roots be softencd in water, sliced, and the juice expressed, which is to be boiled down, with the addition of a little lime, till about two-thirds remain, and afterwards strained. These boilings and strainings are repeated alternately, until the liquid attains the consistence of syrup, when it is left to cool. Thic sugar thus extracted, retains somewhat of the taste of the root, but it may be purified by the same process as refined West India sugar, and it then loses its peculiar flavour. The quantity obtained varies considerably, but in general it averages between four and five pounds from one hundred pounds of the beet-root, beside a quantity of uncrystallizable syrup. In Germany, the expense has been calculated at about three-pence per pound.

Medical Properties and Uses.-The use of this plant as an emollient and laxative is now almost forgotten. The leaves softened by a hot iron, or steeped in beer, were a familiar topical application for dressing issues, blisters, certain sores and ulcers, and even in scald-head *

The powder of the root, and more especially the expressed juicc, is a powerful errhine, and was remarked as such by Galen. It was recommended to be snuffed up the nose in severe head-achc, catarrhs, and tooth-ache, but it is condemned by Borrich as a dangerous sternutatory.

* Lorry de morbis cutaneis, p. 442. 


\section{XVII.}

\section{BETONICA OFFICINALIS.}

Wood Betony.

Class XIV. Didynamia.-Oorder I. Gymnospermia.

Nat. Ord. Labiate.

Gen. Char. Calyx ovate, ten-ribbed; teeth equal, awned. Corolla with the tube exserted, cylindrical; upper lip ascending, plane; lower lip patent, trifid, its middle lobe entire, or nearly so.

Spec. Char. Spike interrupted. Middle lobe of the lower lip of the corolla emarginate. Leaves cordateoblong, crenate.

\section{SYNON YMES.}

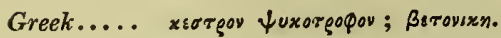

Latin..... $\left\{\begin{array}{l}\text { Betonica purpurea. Bauh. Pin. } 235 . \\ \text { Betonica. Ger. Em. 7l4. Raii Syn. } 238 . \\ \text { Betonica officinalis. Lin. Sp. Pl. } 810 .\end{array}\right.$

French.... Betoine.

Italian.... Bettonica.

Spanish and ?

Portuguese Betonica.

German... Betonik; Betonie; Zehrkraut.

Dutch .... Betonie ; Betony.

Polish .... Bukwika.

Description.-The root is perennial, woody, twisted, brownish, and furnished with long white fibres. The stem is simple, upright, quadrangular, rough with deflexed hairs, and rises about a foot and a half in height. The lower leaves are cordateoblong, and furnished with long footstalks. The upper ones are opposite, oblong, and nearly sessile; the whole of a deep green colour, obtuse and crenate. The flowers are disposed in terminal oblong spikes, rather short and interrupted, with two 
linear, lanceolatc, reflexed bractcæ at the basc. The calyx is monophyllous, tubular, 10-ribbed, and divided at the border into five-toothed acute scgments. The corolla is monopetalous, bi-labiate, purple, with a cylindrical curved tube; the upper lip is plane, entire, and obtuse ; the lower one larger and divided into three lobes, the middle lobe larger, roundish, and slightly notched. The stamens are four didynamous; the filaments awl-shaped, inclined towards the upper lip; the anthers globosc, 2-lobed. The germen is superior, rounded, 4-lobed, supporting a simple filiform style, terminated by a bifid stigma. The fruit consists of 4 oval, brown seeds, situated in the bottom of the persistent calyx. Plate 6 , fig. 2, (a) the entire flower ; $(b)$ the corolla seen in front; $(c)$ the pistil and part of the calyx.

This hardy perennial plant grows in shady places in woods and meadows, flowering in July and August. It is not uncommon in England; rare in Scotland. It often grows in beds, and when peeping up among buslses and low shrubs, has a pretty effect.

Pliny states that the term betonica altered from vetonica, is derived from the Vetones, who inhabited the country at the base of the Pyrennees, and who first brought the plant into notice. This, says Théis, is an error, betonic is the true Celtic name of the plant, and it comes from ben, the head, and ton, good; in allusion to its cephalic properties.

Qualities and General Uses. - The scnsible qualities of betony are rather feeble. The roots liave a bitter and nauseous flavour. The leaves, together with a slight bitterness, have an austere and somewhat saltish taste. The flowers exhale a slight aromatic odour, which is soon dissipated. Bartholinus* relates, that persons employed in gathering betony for medical purposes, have been seized with a kind of intoxication, which caused tliem to commit all kinds of extravagancies. Other similar instances are on record, but if not absolutely untrue, they arc greatly exaggerated.

This plant communicates a fine durable brown colour to wool, which is previously impregnated with a weak solution of bismuth.

Medical Properties and Uses.- Few plants have been

* Historia Anatomicarum Observationum, Obs. 97, Cent. 3. 
more lauded by the ancients than this. Dioscorides and Galen highly celebrate its powers*. It was extolled by Lucius Apulius, and Antonius Musa, physician to Augustus, as an infallible remedy in forty-seven different diseases, among which are enumerated paralysis, madness, and consumption. A plaster of betony has been recommended even in modern days to consolidate fractures of the skull. These extravagant and absurd stories have tended to obscure whatever medical virtues the plant may in reality possess. Murrayt, with great reason, doubts wliether this is

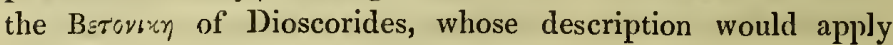
equally well to many other Labiatæ.

Most writers agree that Betony is not entirely destitute of remedial virtues. Scopoli speaks highly of its cephalic and corroborant effects. Geoffroy recommends it in paralysis, hemicrania, and vertigo ; and Etmuller, in all kinds of headaches. A small handful of the plant infused in half a pint of boiling water, makes an excellent tea, of great service in bilious headaches and complaints of the stomach. Its efficacy in gout has also been advanced, but seems rather questionable. The roots are said to be emetic and purgative.

The dried leaves and flowers are sternutatory, and have been found serviceable in headaches. Niemann gives the following formula :

$\left.\begin{array}{c}\text { Take of, Herb of Sage } \\ \text { Betony } \\ \text { Marjoram }\end{array}\right\}$ Of each one handful.

Root of Florentine Iris, one ounce.

Make a powder.

According to Dr. Woodville, this plant and the Eyebright enter into the composition of Rowley's British herb tobacco and snuff.

- The enthusiasm of the Greeks seems to have descended to the Italians, who still have a proverb: "Ha piu virtu che bettonica"- "He has as many virtues as betony ;" and another, "Vende la tonica e' compra la bettonica."

+ Apparatus Medicaminum, Vol. II. p. 191. 
XVIII.

CONVOLVULUS SEPIUM.

\section{Great Bindweed.}

Class V. Pentandia.-Order T. Monogria.

Nat. Ord. Convolvulaces.

Gen. Char. Calyx five-cleft. Corolla campanulate, plaited. Stigmas two, obtuse. Capsule of one to three cells with as many valves; cells one to two seeded.

Spec. Char. Stem climbing. Leaves sagittate, truncate at the base. Peduncles four-sided, single-flowered. Bractex large, cordate, close to the flower.

S Y NON Y M ES.

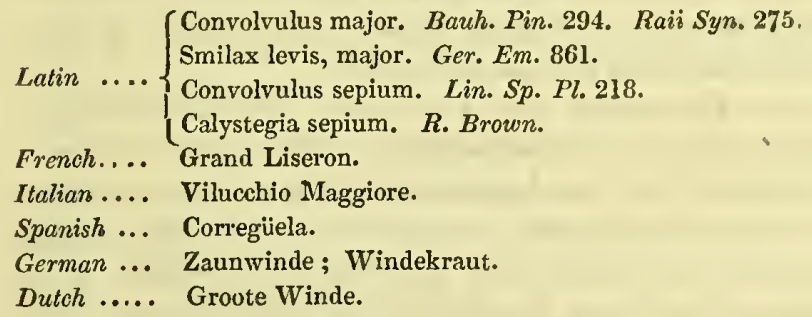

Description.-The root is long, slender, creeping, and fibrous. The stems are climbing, weak, angular, twisted, smooth, and often extend several feet in length. The leaves are large, alternate, arrow-shaped, smooth, of a light green colour, truncate at the base, and supported on long footstalks. The flowers proceed singly from the axils of the leaves, on smooth quadrangular peduncles, with two large cordate bractea placed close to each flower. The calyx is small, inferior, and divided into five ovate permanent segments. The corolla is monopetalous, large, campanulate, regular, snow-white, sometimes with a roseate tinge, with five plaits, and five shallow lobes. The stamens have subulate filaments, half as long as the corolla, and sagittate, erect, terminal anthers. The germen is ovate; the style filiform, as long as the stamens; the stigmas two, 
spreading. The fruit is a globose pointed capsule, with from one to three cells, each containing one or two large roundish seeds. Plate 5, fig. 2, (a) the calyx; (b) the stamens; (c) the pistil.

The great Bindweed is a perennial plant, a native of most parts of Europe, and growing plentifully in this country in hedges and moist woods. It flowers in July and August.

The name is derived from convolvulo, to entwine. It is sometimes called bear-bind, withe-wind, and hedge-bells, and is a great ornament to our hedges in autumn, exhibiting large, showy, white flowers in great profusion.

There are two other species of convolvulus indigenous to this country. The C. Soldanella, which grows on sandy sea-slores, distinguished by its prostrate stem, kidney-shaped leaves, and rose-coloured flowers; and the $\mathbf{C}$. arvensis or small Bindweed, which is known by its creeping root penetrating very deep into the soil, prostrate twining stems, and rose-coloured, yellowish, or white flowers. The latter is found on the borders of most corn-fields, flowering in June and July.

Medical Properties and Uses.-The Sea Bindweed has been long known as an acrid purgative. This quality resides in a milky juice, which exudes from the plant on being wounded. A decoction of from half a drachm to three drachms of the dried leaves was directed for a dose. It was also used as an antiscorbutic, and hence the name Scottish scurvy-grass. The great Bindweed, however, here figured, seems to be the most powerful. The expressed juice of the stem and roots, when dxied, concretes into a resin, which is proposed by Withering as a substitute for scammony, in the dose of twenty or thirty grains, and is recommended by Halley and Dr. Good as a hydragogue purgative in dropsies.

In a recent work on Medical Botany, it is stated, that "twenty pounds of the fresh root, afford a watery extract of one pound twelve ounces, from fifteen to twenty grains of which act freely on the bowels as a drastic purgative, and gripe but little. A pill, composed of one ounce and a half of the extract, two drachms of aloes, and one drachm of ginger, act with certainty and ease, in doses of ten grains, and might be substituted for compound extract of colocynth."**

* Stevenson and Churchill's Med. Botany, Vol. I. 


\section{BETULA ALBA.}

Common Birch.

\section{Class XXI. Moncecia.--Order VI. Polyandria.}

Nat. Ord. Amentacee.

Gen. Char. Barren flowers in a cylindrical catlin; the scales ternate, the middle scale bearing the stamens. Fertile fowers in a catkin whose scales are imperfectly three-lobed, three-flowered. Germen compressed, with two cells, one of which is abortive; styles two. Fruit membranous, winged, one-celled.

Spec. Char. Leaves ovate-deltoid, acute, donbly serrated, nearly smooth.

\section{S Y N ON Y M ES.}

Greek.... onpos; onpuda. Theophrastus.

Latin .... \{ $\begin{aligned} & \text { Betula. Banh. Pin. } 426 . \text { Raii Syn. } 443 . \\ & \text { Betula alba. Lin. Sp. Pl. 1393. }\end{aligned}$

French.... Bouleau; Boulean Blanc.

Italian.... Betula ; Betulla.

Spanish... Abedul.

German ... Birke; Birkenbaum.

Dutch ..... Berkenboom.

Belgic .... Berke-boom.

Polish .... Brzoza.

Swedish ... Biork.

Russiar... Beresa.

Description.-The common Birch is a graceful tree, growing in a favourable soil to the height of forty or fifty feet. The trunk is straight, cylindrical, without knots, and dividing towards the top, into numerous flexible, pendent branches; the bark has a silvery appearance, and when old peels off transversely. The leaves are alternate, petiolate, ovate, somewhat deltoid, acute, irregularly serrate, nearly smooth, and shining. 
The flowers are small, destitute of perianth, amentaceous, and monœcious; the male catkins are long, and composed of ternate scales; the stamens are eleven or twelve, with anthers grouped in fours; the female catkins are shorter and more dense, composed of 3-lobed scales, each of which contains three flowers. The germen is compressed, 2-celled; styles 2, subulate; stigmas simple. The fruit is compressed, membranous at the margin, and contains a single seed. Plate 4, fig. 3, (1*) male catkins; ( $\left.2^{*}\right)$ female catkin; $(a)$ scale detached from the male catkin; $(b)$ scale from the female catkin; $(c)$ scale of the ripe fertile catkin; $(d)$ ripe fruit.

This elegant tree inhabits woods, especially in heathy soils, and in mountainous countries, flowering in the early spring. lt forms extensive natural woods in the Highlands of Scotland, and is one of the last productions of vegetation towards the North Pole. The name is said to be derived from betu, the Celtic appellation of the birch.

Burns has celebrated it as "the fragrant birk in woodbines drest."

Qualities and general Uses.-This tree is applied to numerous important purposes by the inhabitants of Sweden, Lapland, and Russia.

The Laplanders make of the outer bark, shoes for fishing, baskets and fisling lines, by weaving slips of it together. The dishes in which their fish is served at table, are made of the same materials; and a large thick piece of the bark, well dried, with a circular hole in the centre, the size of the neck, serves them for a cloak, which, when the opening in front is closed with a wooden skewer, keeps them dry in the heaviest rains. The inner bark, which is thick, fleshy, fibrous and brittle, is made into nets, and all the Laplanders prepare leather by steeping the ox-hides which they obtain from Norway and Sweden in a warm decoction of the bark, for three successive days. This leather they prefer to any other, as it resists the water better. The Laplanders never make the bark into bread, as the Kamschatdales are said to do*.

In some northern countries, houses are covered with the bark, and it is twisted into torches; good charcoal is made of 
the wood, and an oil is obtained from the degot or white rind, which gives to the well known Russia leather its superior qualities.

Guetard states, that before and subsequent to the æra of Alexander the Great, the white inner bark of the birch was the only paper used by the Gauls. Specimens of this rude material are still preserved in the cabinets of the curious *.

The utility of the birch as a dye, has been confirmed by numerous experiments. It affords a brown, yellow, fawn, or red colour, according to the mode by which it is prepared. It is also reputed to fix the colour of logwood.

In many parts of the country a wine is made of the sap, which is procured in great quantities by boring a hole in the trunk of the tree early in the spring. The incision should be made at the top of the trunk or the branches, and prior to the appearance of the leaves. The juice thus obtained is limpid and sweetish, and readily passes into the vinous fermentation. Inspissated and set aside for some time in a cool place, it deposits crystals of a sweetish taste, resembling manna.

Medical Properties and Uses.-The medical virtues of this tree are few and inconsiderable, nevertheless it has been mucl lauded. The juice before mentioned, given to the extent of from two to five ounces, was esteemed an excellent depurative in cutaneous eruptions, diuretic, diaphoretic, and lithontriptic. Bergius and Rosen state that it is vermifuge. They direct it to be preserved for use, by pouring a little oil on the surface, by which means it may be kept for several months. The leaves and the bark have also enjoyed some reputation as detergents and antiseptics. The Muscovite and Swedish peasants apply the leaves to any part affected with rheumatic pains or gout, and experience relief from their sudorific action. The Laplanders obtain from the fissures of the wood in old trees a substance resembling an Agaric, which they use as moxa, and which forms their chief resource in all complaints where there

* While enumerating the various uses of the birch, we must not omit to notice its manufacture into brooms, and the well known instruments of castigation, the "birchen sprays." It seems to have been an emblem of authority in the early days of the Roman republic, since it was bound up in the fasces which were carried hefore the chief magistrates. 
is much pain and but slight inflammation*. They also make a plaster which is used to promote suppuration, by burning the middle layer of the outer bark, and before it is quite consumed, quenching it in water, and then blending it with the resin of the spruce fir, to a proper consistence.

* Flora Lap. p. 273. Linnæus remarks, it is curious by what mean 3 they could have learned the use of this remedy, since it is used nowhere throughout Sweden. They employ it to such an extent, that their faces and breasts are often covered with hideous cicatrices. 
XX.

\section{ARISTOLOCHIA CLEMATITIS.}

\section{Common Birthwort.}

\section{Class XX. Gynandria.-Order III. Hexandria.}

Nat. Ord. Aristolochies.

Gen. Char. Perianth superior, tubular, coloured, permanent, often swelling at the base, dilated at the mouth. Anthers six, subsessile, inserted round the base of the style. Stigma with six lobes. Capsule inferior, with six cells.

Spec. Char. Stem erect. Lueaves heart-shaped. Flowers upright; lip oblong, shortly acuminate.

\section{SY NONYMES.}

Greek..... a a

Latin..... $\left\{\begin{array}{l}\text { Aristolochia Clematitis recta. Bauh. Pin. } 307 . \\ \text { Aristolochia Saracenica. Ger. Em. 847. } \\ \text { Aristolochia Clematitis. Lin. Sp. Plan. } 1364 .\end{array}\right.$

French... Aristoloche commune.

Italian.... Aristolochia.

Spanish ... Aristoloquia comun.

German ... Waldrebe Osterhzey; Waldreben Hohlwurzel.

Duich .... Holwortel; Osterlucy.

Belgic.... Dunne Holwortel; Sarratyns-kruid.

Description.-The root is perennial, long, cylindrical, slender, creeping, and fibrous. The stems are simple, upright, round, and striated, growing in a zig-zag direction, about two feet in height. The leaves are alternate, petiolate, smootl, heart-shaped, obtuse, of a bright green colour above, paler, and veined beneath. The flowers are of a greenish yellow colour, and rise several together from the axils of the leaves, on short peduncles. The perianth (calyx) is monophyllous, tubular, swelling at the base, lilated on one side at the mouth, and lengthened into a strap-like lobe. The anthers are six in num- 
ber, situated on the germen, sessile, two-celled. The germen is inferior, oblong, angular, surmounted by a very short style, and a concave stigma with six divisions. The fruit is an oval capsule, with six corners and six cells, and as many valves, each cell containing numerous triangular seeds. Plate 6, fig. 1, (a) the pistil, showing the inferior ovary, the very short style, and the stigma divided into six parts, at the base of which the anthers are situated; $(b)$ the ripe fruit, cut transversely to show the six cells.

The common Birthwort is found in most of the temperate countries of the world. It occurs in Britain, but is not very frequent, in woods, copses, and near the ruins of nunneries in the south-east of the island. It flowers in July and August.

The generic name is formed from apisos excellent, and $\lambda \circ \chi^{\varepsilon l \alpha}$, the puerperal state, in allusion to its reputed virtues in exciting the lochial discharge; it is called clematis from $x \lambda \eta \mu \alpha \tau i s$, a little vine.

Quacities. - The root has a slight aromatic smell, and a warm, bitterish taste. The juice gives a red tinge to blue paper, and the aqueous infusion is not altered by sulphate of iron. Spirit is the best menstruum for extracting the virtues of the roots; but by distillation in water a small quantity of essential oil is obtained, having the odour and taste of the root. Orfila enumerates this plant among the narcotico-acrid poisonous, but the quantity requisite to produce poisonous effects is so large, that accidents very seldom occur.

Medical Properties and Uses._-Hippocrates, Galen, and other writers, both of remote and recent times, highly extol the powers of aristolochia. The root has been used for suppressing uterine purgations, and as an alterant in gout. Dr. Gilibert attributes to the infusion diuretic and emmenagogue properties, and recommends the powder of the root in wine, to be given in chlorosis, dropsical affections, intermittent fevers, and humid astlima. The dose of the infusion is half an ounce; of the powder from a scruple to a drachm and a half. A modern author bears witness to the successful employment of a decoction of this root in the form of clysters in the internal piles, which having suppurated were near producing fistula.

Dr. Cullen says, "In some cases of retention and chlorosis, as a warm and stimulating medicine, I have found it useful. It 
makes a considerable part of the Portland powder, and lias often been employed in the same manner as that powder, to be taken every day for a length of time. But though it may prevent the recurrence of the gouty paroxysms, the long-continued use of such medicines is extremely hurtful, and commonly brings on a general state of disease more fatal than the original distemper." * Its use as a vulnerary, in common with many others, is now obsolete.

There are several other species of Aristolochia possessing medicinal properties, and the A. Serpentaria, Virginian snakeroot, or Birthwort, is a valuable stimulating diaphoretic and tonic.

* Materia Medica, Vol. II. p. 296. 
XXI.

\section{POLYGONUM BISTORTA.}

\section{Great Bistort, or Snakeweed.}

Class ViII. Octandria.-Order III. 'Trigynia.

Nat. Ord. Polygone.e.

Gen. Char. Perianth single, petaloid, inferior, coloured, in five deep persistent segments. Stamens five to eight. Styles two to three. Fruit a two or three-cornered indehiscent, one-seeded nut.

Spec. Char. Stem simple, bearing one spike. Leaves ovate, waved; the radicle ones tapering into a footstalk.

S Y N O Y M ES.

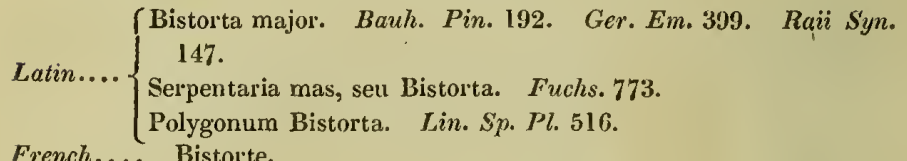

Bistorte.

Italian.... Bistorta.

Spanish and
Portuguese Bistorta.

German... Natterknoterich; Weizenknœterich; Natterwurz.

Dutch.... Naterwortel; Slangenwortel; Hartstonge.

Danish.... Slangeort.

Polish .... Wezownik.

Swedish ... Ormrot.

Description.-The root is perennial, woody, tortuous, dark brown externally and redish within, about the thickness of the finger, and furnished with numerous slender fibres. The stem is simple, erect, cylindrical, knotted at the joints, striated, smooth, and attains the height of a foot or eighteen inches. The leaves are alternate, ovate, entire, smooth, and waved ; the radical ones are large, and gradually tapering into a long footstalk; those of the stem are smaller, clasping, and sub-sessile, each with a long membranous stipule. The flowers are disposed 


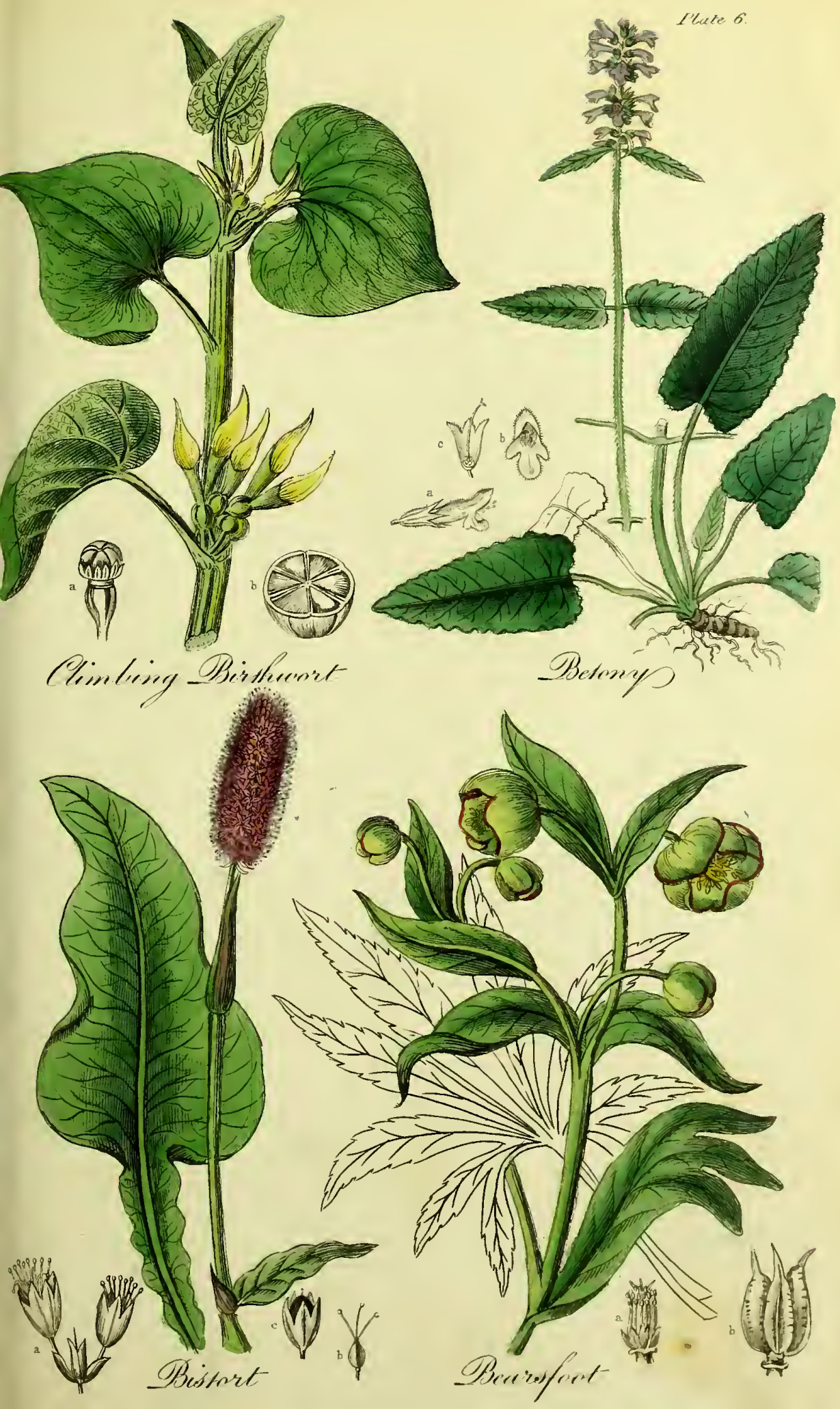



in a terminal, dense, cylindrical spike; each flower is supported on a very short stalk, with shining, serrate, membranous bracteæ at the base. The perianth (calyx) is of a light rose colour, and divided into five deep persistent segments. The stamens are eight, tapering, longer than the perianth, with purple anthers. The germen is superior, triangular, supporting three filiform styles, each terminated by a small, slightly capitate stigma. 'The fruit is a triangular, pointed nut, containing a single seed, and surrounded by the persistent calyx. Plate 6, fig. 3, (a) two flowers of unequal length, detached from the spike, with the membranous bracteæ at the base; (b) the pistil; (c) the ripe fruit, accompanied with the persistent calyx.

Bistort is a native of Switzerland, the south of France, Germany, Holland, Siberia, and Japan, and is found abundantly in moist meadows in various parts of Britain. It flowers in June.

The name of the genus is taken from $\pi^{\circ} \circ \lambda$ us, many, and yovu, $a$ joint, in allusion to the numerous' joints of the stem. The term Bistorta is compounded of bis, twice, and tortus, twisted, expressive of the figure of the root.

Qualities and generat Uses.-Most parts of this plant are applied to useful purposes. Cattle in general are fond of it, though horses refuse it. The seeds have been used as food for birds and poultry. The young leaves and shoots were formerly eaten in herb puddings, and boiled as greens in the north of England, where the plant goes by the name of Easter-giant and Patience-dock. The root, however, is the most valuable part of the plant, and few indigenous vegetables possess greater astringency. It has been found to contain a large proportion of tannin and gallic acid; oxalic acid was also detected in it by Scheele.

After repeated washings, the root of bistort loses its styptic qualities, and affords a considerable quantity of foecula, resembling starch, which in many northern countries, especially Russia, is mixed with wheaten flour and made into bread.

Medical Properties and Uses.-This plant has fallen into undeserved neglect in modern days. Dr. Cullen observes, "Both by its sensible qualities, and by the colour it gives with green vitriol, and by the extracts it affords, Bistort seems to be one of the strongest of our vegetable astringents. As such we 
have frequently employed it, and particularly in internittent fevers, in the quantity of three drachms daily." The powdered root, in doses of a drachm, has also been given in hemorrhage, diarrhœa, and chronic dysentery.

Geoffroy' recommends it in incontinence of urine, gonorrhœa, excessive menstruation, spitting of blood, and bilious vomitings ; but it is not employed in these complaints by modern physicians. The inhabitants of the Alps, according to Chomel, consider it a specific in fluor albus.

Ratier directs a decoction to be made thus-

Take of Root of Bistort .......... One ounce.

Water................ Two pints.

After sufficient boiling, strain. Dose, from one to three ounces.

The decoction forms an excellent gargle for scorbutic gums and ulcerated sore throat.

* Materia Medica, Vol. II. p. 40.

+ Materia Medica, Vol. III. p. 195. 


\section{XXII.}

\section{POLYGONUM HYDROPIPER.}

Biting Persicaria, Arsmart, or Water-Pepper.

\section{Class VIII. Octandria.-Order I. Trigynia.}

Nat. Ord. Polygoner.

Gen. Char. See Bistort.

Spec. Char. Flowers hexandrous, half-digynous. Leaves lanceolate, waved, not spotted. Spikes filiform, drooping. Stem erect.

SY NON Y II ES.

Persicaria urens, seu Hydropiper. Bauh. Pin, 101.

Latin .... \{ $\begin{aligned} & \text { Persicaria acris, sive Hydropiper. Raii Syn. } 144 . \\ & \text { Polygonum Hydropiper. Lin. Sp. Pl.517. }\end{aligned}$

French .... Persicaire brulante : Poivre d'eau ; Curage.

Italian.... Pepe aquatico.

Spanish .... Pimienta de agua

Portuguese. Pimenta de agua.

German... Wasserpfeffer; Bitternknœterich.

Dutch .... Water-peper.

Danish.... Vand peber.

Swedish.... Bitterblad.

Polish..... Pieprz wodny.

Russ..... Potschednaja trawa.

Description.-The root is annual, aquatic, fibrous. The stems are smooth, cylindrical, articulated, nearly erect, often branched, tinged with red, and about two feet in height. The leaves are simple, alternate, smooth, shortly petiolate, lanceolate, acute, wavy, free from spots, and furnished at the base with short truncated stipules of a reddish hue. The flowers are dis- 
posed in lax, filiform, drooping spikes, which are lateral and terminal, and furnished with scaly bracteæ. The perianth (calyx) is generally four-lobed, inferior, persistent, and tinged with pink. The stamens are six, with short filaments and roundish anthers. The germen is superior, trigonous, compressed; the styles are two, united half way up, terminated by single stigmas. The fruit is a compressed, triangular nut, containing a single seed. Plate 4, fig. 4, (a) the calyx laid open to show the stamens; (b) the pistil ; (c) the seed magnified.

This plant grows abundantly by the sides of lakes and ditches in this country, and throughout the greater part of Europe. It flowers from July to September.

The specific name is a compound of the Greek viwg, water, and the Latin piper, pepper; of which there are synonymes in many languages.

Qualities and general Uses. - This plant has an acrid, biting taste, slightly resembling that of peppermint, which is supposed to reside in the glandular dots sprinkled over its surface. It loses much of this property by drying, and like arum, the acrimony is destroyed in the process of distillation. Bergius remarks that the aqueous infusion is blackened by sulphate of iron,-a sure indication of an astringent principle. It has been used to dye woollen cloth of a yellow colour. It is not eaten by any animal. In some parts of Germany they keep this herb in their bed-rooms for the purpose of dispersing fleas, as these insects, they say, will not come where it is.

Farriers sometimes use this plant as an application to fungous flesh, and ulcers in animals, and a drachm of the powder of the dried herb given in honey is said to destroy a species of worm which often proves fatal to sheep.

Medical Propertes and Uses.--The Biting Persicaria is another of those plants which are discarded from modern practice. Its pungency has caused it to be employed as a rubefacient to the skin, in the same manner as mustard. It was highly commended for cleansing atonic ulcers and in gangrene. The leaves infused in boiling water, or a strong decoction of them, were also applied to tumours, bruises, and contusions. Linnæus*, states that the Norwegians use the recent herb as a 
remedy for tooth-ache, either chewed or applied externally in the form of a poultice, or a strong decoction as lot as can be borne.

The distilled water was highly recommended in calculous affections by the learned Boyle, but it is now disused except as a cosinetic.

A decoction made by boiling half an ounce of the dried plant in a quart of water down to a pint, is said to be diuretic, and very efficacious in dropsy, jaundice, and obstructions of the viscera. 


\section{XXIII.}

\section{SOLANUM DULCAMARA. \\ Bitter-sweet, or Woody Nightshade.}

Class V. Pentandria.-Order I. Monogynia.

Nat. Ord. Solaner.

Gen. Char. Caylx five to ten-parted. Corolla rotate. Anthers opening with two pores at the extremity. Berry two or more celled.

Spec. Char. Stem without thorns, shrubby, climbing. Leaves cordate, the upper ones hastate. Clusters cymose, drooping, opposite the leaves.

\section{S Y N O Y M E S.}

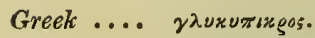

Latin.... $\left\{\begin{array}{l}\text { Solanum scandens, seu Dulcamara. Bauh. Pin. } 176 . \\ \text { Amara dulcis. Ger. Em. 350. } \\ \text { Solanum lignosum, seu Dulcamara. Raii. Syn. } 265 . \\ \text { Solanum Dulcamara. Lin. Sp. Pl. 264. }\end{array}\right.$

French.... Douce-amere; Morelle grimpante.

Italian... Amara-dolce; Dulcamara.

Spanish... Dulzamara; Manzana ägri dulce.

Portuguese Docamarga.

German .. Bittersuess; Alfranken; Hirschkraut.

Dutch .... Bitterzoet; Alfs-ranken; Elfranken.

Polish .... Psinki-wodni.

Swedish .. Qweswod.

Description.-The root is perennial, slender, woody, branched, and fibrous. The stems are cylindrical, climbing, shrubby, alternately branched, somewhat angular, and attain the height of six or seven feet. The bark of the main stem is ash coloured ; that of the branches purplish. The leaves are alternate, acute, glabrous, sometimes pubescent, and stand on long footstalks; the lower ones are ovate, somewhat cordate, entire; the upper 

halbert-shaped. The flowers are disposed in elegant, pendulous, cymose racemes, opposite the upper leaves or terminal. The calyx is small, and divided into five obtuse segments. The corolla is wheel-shaped, divided into five refiexed, equal, acute segments of a reddish purple colour, with two whitish green tubercles at the base of each. The stamens are five, terminated by large yellow anthers united into a cone-shaped figure. The germen is roundish, supporting a thread-shaped style, longer than the stamens, and terminated by an obtuse stigma. The fruit is a smooth, oval berry, of a scarlet colour, containing numerous seeds, attached to a fleshy receptacle. Plate 7, fig. 3. (a) calyx, stamens, and pistil; (b) corolla! laid open; (c) a single stamen, showing the mode in which the pollen is discharged from the apertures at the top of the anther; $(d)$ the pistil; (e) the fruit cut longitudinally to show the position of the seeds.

This plant occurs in moist hedges and thickets throughout the greater part of Europe. It is found in similar situations in this country, embellishing the sturdy shrubs round which it climbs for support, with its elegant flowers and brilliant fruit. It continues in flower from June to August.

The etymology of the term Solanum is involved in some obscurity; some have derived it from solari, to comfort, but the application of this is far from satisfactory. The present species is called Dulcamara from dulcis, sweet, and amara, bitter, because of its bitter, and subsequently sweet taste in the mouth.

Qualities.-The root and stem of the woody Nightshade, when bruised, diffuse a nauseous odour, and whether fresh or dried, invariably possess the union of properties to which the plant owes its trivial name. The recent leaves are said to exhale occasionally a slight musky smell, but when dried they are quite inodorous. M. Guersent thinks that the saccharine principle resides in the ligneous part, and the bitter principle in the cortical part of the old stems. Water extracts the virtues of the plant better than alcohol. An aqueous infusion from one ounce of the twigs, afforded, according to Hartmann and Kuhn, five drachms and thirty-five grains of extract, while the spirituous tincture from a like quantity gave only two drachms and a half*.

* Murray, Apparatus Med. Vol. I. p. 605. 
The activity of this plant is supposed to depend on an alkaloid, called by Defosses, who first discovered it, Solania or Solanine, which is also found in the berries of the garden nightshade, but not in the leaves. Solania is obtained by treating the filtered juice with ammonia, whereby a greyish precipitate is formed. This deposit, collected upon a filter, washed, and treated with boiling alcohol, yields by evaporation the above salifiable base. When pure, it is white and opaque, having no smell, but a slightly bitter and nauseous taste. It requires 8000 times its weight of hot water for solution, and is but sparingly soluble in alcohol. It has an alkaline reaction, and with acids forms neutral salts. Its action on animals is, to produce vomiting, which is generally succeeded by lethargic drowsiness.

Poisonous Properties.-The berries of the woody Nightshade are looked upon with terror by the peasantry, who rank them with the shining fruit of the bryony, under the name of "poison-berries." The accounts of their deleterious nature have probably been much exaggerated, for Duval gave sixty, and even a hundred berries to dogs without any appreciable results ; and the acute physiologist Magendie states, that he " would not hesitate to take those substances himself which he has observed to be innocuous to animals." Moreover, half an ounce of the extract has been taken by an adult without any inconvenience*. Some cases of their noxious, and even fatal effects on children are recorded, but we are not assured that the berries were those of this plant; they might have been gathered from the bryony, which is equally common in hedges. Nevertheless, the bitter-sweet belongs to a suspicious tribe, and parents should warn their offspring of the danger of eating its tempting fruit. If untoward symptoms are produced by this or any other vegetable, medical assistance should be promptly obtained.

Medical. Properties and Uses. - The ordinary effects of this plant are narcotic and diuretic. In large does it occasions nausea, vomiting, syncope, palpitation, and convulsive twitchings of various parts of the body. "Its influence on the nutritive functions is shown by the alvine evacuations, the increase of perspiration, and abundant secretion of urine. It also augments the product of the mucous secretions, and in some cases facilitates expectoration."

Whatever may be the medical value of the Dulcamara, it has been extensively employed in various acute and chronic dis-

* Flore Medicale, p. 173. 
eases. Linnæus* and Carreret employed it with advantage in chronic rheumatism. Bergius gave from five to ten grains of the extract twice or thrice a day, in gout; and other eminent practitioners, have recommended it in incipient phthisis, pleurisy, asthma, jaundice, and dropsy; also in uterine obstructions and suppression of the lochia. The best effects, however, have been obtained from it, in some obstinate cutaneous affections Dr. Bateman considers it one of the most effectual remedies for leprosy under all its varieties. Herpetic eruptions have been known to yield to its internal and external use, and it has been recommended by Linnæus in some of the secondary forms of syphilis.

The twigs are the part employed in medicine, and for this purpose they should be gathered in autumn after the leaves have fallen. The decoction is thus made.

Take of Stalks of Woody Nightshade, sliced .... An ounce.

$$
\text { Water .................................. }
$$

Boil to a pint, and strain. Dose, from one to three ounces. "The addition of a little cinnamon lenders the decoction less apt to offend the stomach."-Bigelou".

The external use of the leaves is now nearly forgotten, but in rustic practice they are sometimes applied externally, in form of poultice or fomentation, by beating up the leaves and stalks with a little hot water, or by making a strong decoction of them. These preparations are deemed of service in all hard and painful swellings, especially those of the knee-joint, or in the female breast; also in all contusions and bruises, for promoting the absorption of extravasated blood, by which means the blackness is speedily removed.

* Dissertatio de Dulcamara, in Amæn. acar. Vol. VIII.

+ Memoire sur les vertus de la Douce-amere, p. 53.

+ The women of Etruria, according to Matthiolus, employed the juice of the berries as a cosmetic ; and a decoction of the stems is said to render the skin smooth and pleasant. 


\section{XXIV.}

\section{CENTAURIA CYANUS.}

\section{Common Blue-Bottle.}

\section{Class XIX. Syngenesia.-Order III. Polygamia Frustranea.} Nat. Ord. Cомposita.

Gen. Char. Involucre scaly. Receptacle bristly. Pappus simple, or none. Corollas of the ray funnel-shaped, irregular, longer than those of the disk.

Spec. Char. Scales of the involucre serrated. Leaves linear, entire, the lowermost toothed.

S Y NON Y M ES.

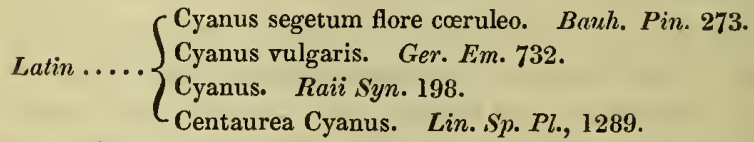

French.... Bluet; Aubifoin; Casselunette; Barbeau.

Italian .... Ciano.

Spanish ... Ciano.

German.... Kornblume.

Duteh..... Kornbluem.

Belgic .... Koorn-bloemen ; Rogge-bloemen.

Description.-The root is annual, rather woody, and fibrous. The stems are slender, branched, striated, covered with a loose cottony lown, and attain the height of two or three feet. The leaves are alternate, long, straight, of a light green colour, somewhat cottony, especially beneath; the lower ones are generally toothed towards the base; the upper ones are linear and entire. The flowers are terminal, capitate, tubular, and five-toothed; the receptacle bristly; the involucre imbricated with scales of a greenish colour, their margin purple, ciliated and serrated. The florets of the circumference or ray are large, 
azure-coloured, funnel-shaped, while those of the disk are small and purplish; but the latter are perfect and fertile, the former neuter*. The stamens are five, inserted upon the corolla between its lobes, with the filaments distinct, and the anthers united into a tube. The ovary is simple, adherent with the calyx, which is placed beneath it, surmounted by a single style sheathed by the anthers and terminated by a bifid stigma. The fruit is an acheninm, crowned by a simple spreading pappus. The seed is şolitary in the pericarp, erect, withont albumen. Plate 5, fig. 3, (a) floret of the circumference or ray; (b) floret of the disk; $(c)$ the seed crowned by the pappus.

This plant grows abundantly in corn-fields, embellishing them with its brilliant flowers, which appear in July and August. The name is said to be derived from the Centaur Chiron, who with some plant of this genus was fabled to have cured himself of a wound made by Hercules. It is called Cyanus from xuaveos, azure-coloured.

Qualities AND USES.-This plant has little to recommend it but its ornamental character. Several varicties are cultivated in gardens, with white and purple flowers, but they must all yield in beauty to the denizen of the fields. The expressed juice of the florets, with the addition of a little alum, makes a good ink; and may also be used as a water-colour, and for staining linen blue; but it is said not to be permanent.

Medical Properties and Uses $\uparrow$ - The Cyanus was reckoned, by the credulons of former times, antispasmodic, aperient and diuretic, and contributed to swell the catalogue of vulneraries, being applied to contusions, wounds, and bites of venomous beasts. Ray mentions that the powder is of the utmost service sprinkled over erysipelatous affections. A famous collyriun,

* And thus, fiom their not contributing to the production of seed, they go to constitute the order Frustranea, so called from the Latin frustra, useless.

+ The introduction of this and a few others among medicinal plants, may perhaps be reprehended; therefore, it may be as well to state, that they are admittcd partly on account of the interest that attaches to them as relics of a by-gone age, and because some of them are still used as empirical remedies, with the real nature of which it is expedient to be acquainted. Moreover, the plant jnst described is almost the only example that can he selectcd from the British Flora of the hotanical order to which it belongs. 
called in France Eau de Casselunette, was made from the flowers; and the distilled water is not yet banished from the Parisian Codex, which directs it to be made from one part of the flowers and two parts of water, distilled to one part and a half.

The Eau de Casselunette, or break spectacle water, was deemed an excellent remedy in all cases of chronic inflammation of the eyes, and in dimness of sight. 
XXV.

\title{
BORAGO OFFICINALIS.
}

\author{
Common Borage.
}

\section{Class V. Pentandria.-Order I. Monogynia.}

Nat. Ord. Boragines.

Gen. Char. Calyx five-cleft. Corolla rotate, with five acute segments; orifice closed with five obtuse, emarginate teeth. Nuts wrinkled.

Spec. Char. Limb of the corolla flat, much longer than the tube ; orifice with a double row of valves, the innermost awl-shaped, bearing the stamens. Lower leares obovate.

\section{SY NON Y MES.}

Latin .... $\left\{\begin{array}{l}\text { Buglossum latifolium, Borrago. Bauh. Pin. } 256 . \\ \text { Borago hortensis. Ger. Em. 797. } \\ \text { Borago floribus cœruleis et albis. Raii Syn. } 228 . \\ \text { Borago officinalis. Lin. Sp. Pl. 197. }\end{array}\right.$

French.... Bourrache commune.

Italian.... Borragine; Borrana.

Spanish.... Borraja; Borraxa.

German.... Borretseh; Burretsch.

Duteh..... Bernagie; Bernasie.

Polish..... Borak.

Description.-The root is long, whitish, divided, fibrous, mostly biennial. The stem is much branched, erect, cylindrical, thick, succulent, clothed with stiff hairs, and about two feet in height. The leaves are alternate, undulated, hispid, and of a deep green colour; the lower ones obovate, petiolate, and eared at the base; the upper ones ovate, and nearly sessile. 
The flowers are large and disposed in terminal drooping racemes, on long peduncles. The calyx is divided into five deep, linear-lanceolate, persistent segments. The corolla is of a brilliant blue colour, monopetalous, wheel-shaped ; the tube short; the limb deeply divided into five acute segments; the orifice closed with five prominent teetl, which are obtuse and notched at the end. The five stamens are very prominent; the filaments tapering, converging; the anthers oblong, connivent, fixed to the middle and inner side of the filaments. The germen is four-parted, with a cylindrical style, longer than the stamens, terminated by a simple clavate stigma. The fruit consists of four one-seeded carpels. The seeds are irregular, ovate, wrinkled. Plate 7, fig. 2, (a) the corolla, at the base of the tube of which are seen the valves bearing the stamens; (b) the pistil; (c) one of the four nuts of the ripe fruit.

The Borage is a native of Southern Europe, but having been long cultivated in this country, it has become naturalized, and is sometimes found on rubbish and waste ground. It flowers in June and July. Varieties are met with in gardens, with white or purple flowers and variegated leaves.

The name is derived from cor, heart, and ago, to bring; because the plant was reputed to exhilarate the spirits*.

Qualities and general Uses. - The young and tender leaves are used as salads or pot-herbs and formed an ingredient with lemon, sugar, wine and water, in the old English beverage, called a " cool tankard."

Bees are fond of the flowers and frequent them much in summer and autumn.

The stem and leaves contain a viscous juice of a saltish taste. This juice or a decoction of the leaves, inspissated, after a few lays deposits crystals, which yield a great deal of nitre and muriate of soda $\uparrow$, and which deflagrate on burning coals.

Medical Properties and Uses.-Geoffroy $\ddagger$ asserts that this plant attenuates gross and thick liumours, removes obstructions, increases the secretions, especially urine, perspiration and expectoration. He ordered it in pleurisy, peripneumonia, and in

"Hence the old adage, "Borago, gandia semper ago."

+ Common salt.

† Mat. Med. t. III. p. 203. 
hypochondriacal and hysteric complaints. For these purposes the expressed juice was given in the dose of a table-spoonful every three hours, or an infusion was made witls an ounce of the flowers in a pint of white wine, which was taken in the quantity of a wine glassful at a time. A conserve and a distilled water were also directed to be made with the flowers.

The refrigerant and aperient virtues of the plant, which are not considerable, must reside in the saline juice of the stem and leaves, therefore the preparations made with the flowers are not indebted to borage for their efficacy. 


\section{XXVI. \\ RUBUS FRU'TICOSUS.}

Common Bramble or Blackberry.

\section{Class XII. Icosandria.- Order III. Polygunia.}

Nat. Ord. Rosaces.

Gen. Char. Calyx somewhat campanulate, five-cleft. Petals five. Fruit superior, of several succulent drupes, placed upon a protuberant, dry receptacle.

Spec. Char. Stem arched, angular, furrowed. Panicles long, narrow, downy. Leaves digitate; leaflets obovate, hard, decurved at the edges, white beneath.

S Y NONYMES.

Latin.... \{ $\begin{aligned} & \text { Rubus major, fructu nigro. Bauh. J. ii. 57. Raii Syn. } 467 . \\ & \text { Rubus. Ger. Em. 1272. }\end{aligned}$ French .... Ronce ordinaire; Murier des haies.

Italian.... Rovo.

Spanish... Zarza; Mata espinosa.

Portuguese.. Sylva.

German..... Brombeerstrauch.

Dutch..... Braamen.

Swedish... Bromber.

Polish .... Jezyny.

Russian.... Jaschewika.

Descriptron.-The stems are very long and sometimes an inch in thickness, deeply furrowed and angular, mostly hairy, when old of a purplish hue. The prickles grow upon the angles of the stem, and also on the panicles and leaf-stalks, they are strong, sharp, and somewhat hooked. The leaves consist of five, stalked, acute, serrated leaflets, varying in figure, but generally obovate, with the edges and point curved downwards, smooth, dark green above, downy and white beneath. The stipules are two, at the base of the leaves. The flowers are 
disposed in long, narrow panicles. The calyx consists of five, short, woolly, reflexed segments. The petals are obovate, spreading, delicate, and crumpled, of a light pink colour, sometimes white. The stamens are numerous, inserted on the calyx, with slender filaments, shorter than the petals; the anthers are globose, compressed, two-lobed, and two-celled, bursting longitudinally. The germens are numerous, superior, one-celled; the styles small, hair-like, lateral ; the stigmas simple and persistent. The fruit is nearly globular and of a purplish black colour, composed of numerous, close, juicy drupes, placed upon a protuberant, spongy receptacle. "The seeds are small, solitary, oblong. Plate 5, fig. 4, (a) stamen; (b) pistil.

This sturdy shrub *, common in every hedge in this country, occurs as far north as Sweden. It flowers in July and August, and the fruit ripens in September.

The name is supposed to be derived from the Latin ruber or the Celtic rud, red.

Qualities and general Uses. - The bramble is applied to several economical purposes. It is useful in forming hedges. The shoots are very tough, and are employed by thatchers for binding their roofs, and by straw-hive and mat makers. The well known fruit is made into pies and puddings by the cottager. The berries, eaten at the moment they are ripe, are cooling and grateful; a little before, they are coarse and astringent; and a little after disagreeably flavoured or putrid $\uparrow$. The injurious effects attributed to them, when eaten plentifully by children are probably owing to the latter circumstance. Ray mentions that a good and pleasant wine has been made with the jnice, which possesses considerable strength and a pleasant flavour. Some of the muscadine wines of France are coloured with the fruit.

Medical Properties and Uses. - This plant is introduced for the reasons mentioned at page 81 , and because it may be worth while to ascertain how far it merits the character so confidently given to it by the old physicians, viz.: that of a powerful as-

* The genus is remarkable for the manner in which its stems vegetatethe root sends out suckers or stolones which curve dowuwards to the earth, and take root at the end. In the winter the shoot is partly destroyed, but produces blossoms and fruit the ensuing summer, and then dies.

† Loudon's Encyclopædia of Plants, p. 452. 
tringent. It was used in all kinds of hæmorrhages, whether from the uterus, the lungs, the nose, or any other part of the body. For this purpose the leaves were gathered in the spring, and dried; a good handful of them was infused in a quart of boiling water, and the infusion was ordered to be drunk freely.

The bruised leaves were applied to grangrenous ulcers, and Etmuller recommends a decoction of the young leaves in wine, to be applied to certain cutaneous affections.

An old writer says, "The most dangerous floodings will yield to this remedy, and the fluor albus, has frequently been cured by a decoction of these leaves, when every other remedy had failed. They form also an excellent gargle in sore throats, especially where there is ulceration." 


\title{
XXVII.
}

\section{VERONICA BECCABUNGA.}

\author{
Brooklime.
}

\section{Class II. Diandria.-Order I. Monogynia.}

Nat. Ord. Scrophutarinem.

Gen. Char. Calyx four or five-parted. Corolla rotate; the limb four-parted, unequal. Capsule two-celled.

Spec. Char. Racemes lateral. Leaves elliptical, obtuse, subserrated, glabrous. Stem procumbent, and rooting at the base.

\section{SYNONYMES.}

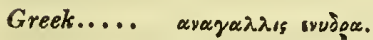

(Anagallis aquatica major folio subrotundo. Bauk. Pin. 252.

Latin ..... Anagallis seu Beccabunga. Ger. Em. 620.

Veronica aquatica rotundifolia, \&c. Raii Syn. 28.

(Veronica Beccabunga. Lin. Sp. Pl. 16.

French.... Beccabunga; Beccabonga; Veronique aquatique.

Italian.... Anagallide aquatica ; Beccabungia.

Spanish ... Becabunga ; Becabunca.

Portuguese. Beccabunga.

German... Bachbungen; Bachbonen ; Wasserbungen.

Dutch .... Beekeboom.

Danish ... Bekbung; Temmike.

Swedish ... Backabunga.

Polish.... Potocznik.

Description.-The root is perennial, creeping, whitish, and fibrous. The stem is cylindrical, smooth, succulent, procumbent, ronting, of a reddish colour at the base, and rises from 
one to two feet in height. The leaves are opposite, broad, elliptical, glabrous, succulent, with short petioles, and somewhat serrated at the margin. The flowers are disposed in lateral axillary clusters, each flower standing on a slender pedicel, furnished with two bracteæ at the base. The calyx is persistent, with four divisions. The corolla is bright blue, monopetalous, wheel shaped; the limb divided into four unequal segments, of which the lower is smallest. The two stamens are inserted into the short tube of the corolla, with spreading filaments, and oblong, somewhat arrow-shaped anthers. The germen is superior, compressed laterally, surmounted with a filiform style, and a simple emarginate stigma. The capsule is ob-cordate, compressed, 2-celled, 4-valved, containing many roundish and dark coloured seeds. Plate 7, fig. 1, (a) the corolla ; (b) calyx and pistil ; $(c)$ fruit.

The name Veronica is of doubtful origin ; it is generally supposed to have been altered from Betonica; that of Beccabunga, is Latinised from the German, bachbunge; bach in German, beek, in Dutch, and beck in provincial English, signifying a brook.

The Brooklime is a well known aquatic plant, occurring in every limpid stream, and exhibiting its bright blue flowers throughout the summer montlis. It is so vivacious as to brave the scorching heat of Africa, and the frosts of northern Europe, while it flourishes luxuriantly in the intermediate regions.

The Water Speedwell (V. anagallis) bears a considerable resemblance to this species, but is distinguished by its longer leaves and racemes of flowers, and erect stem. Of the other species, the pretty Germander Speedwell(V. Chamœdrys) is most common, and yields to few spring flowers in simple beauty.

Qualities and general Uses.-The Brooklime is chiefly used as a spring salad, gatlered and eaten with water-cress, and the Water Speedwell, which closely resembles it in appearance, may be employed in the same manner.

The leaves and stem have a bitterish and sub-astringent taste, with little or no acrimony. They are shown by cliemical experiments, to be subacid and slightly astringent.

Medical Próperties and Uses.-Boerhaave, Simon Pauli, and Vogel, speak of the efficacy of this plant in the highest terins, and it has always been a favourite remedy in scorbutic 
and cutaneous affections ; but nore has been expected from it than sober opinion would justify, and it has accordingly fallen into disuse. Dr. Guersent, an eminent French physician, thus ably describes its character.

"In the early spring, when its growth is just commencing, and towards the end of summer, when fructification is proceeding, the Brooklime is merely aqueous, or astringent, and almost tasteless, but when the plant is fully developed, and ready to flower, it has a slightly bitter and acid flavour, rather more acrid and biting than that of water-cress. These sensible properties are much more apparent in those plants which grow on the banks of rivulets, and are exposed to the sun, than in those which vegetate under water or in the sliade. Whatever may be its natural affinities, it has certainly less analogy, in a medical point of view, witl the veronicæ, than with the fanily of the cruciferæ; it agrees with them in its oily principle, which is pungent and volatile, and only differs from them in being less acrid, and a little astringent. For this reason it is sometimes preferred to more active stimulants, which may occasion too much irritation and heat, and is not unfrequently added to the juice of cruciferous plants to modify their effects. The Brooklime acts in the same manner as those vegetables which are designated by the name of antiscorbutics, though it does not appear to be endued witl any special advantages. On account of its exciting and slightly tonic properties, it is suitable in some cutaneous and scorbutic affections; it has also appeared to be serviceable in some kinds of phthisis, and atonic engorgements of the abdominal viscera which liave supervened to irregular gout."**

As an antiscorbutic, the expressed juice has been recommended, in the quantity of two or three ounces taken every morning, either alone, or mixed with that of water-cress or scurvy-grass, or in a little milk. A conserve made of the fresh leaves, or a syrup from the juice, were formerly substituted for the above, as more palateable, but they are now seldom administered. The bruised herb has been applied externally, for the purpose of cleansing foul ulcers, and to relieve piles, whitlows, and burns. 
Etmuller recommends vapour baths prepared with this plant, together with its internal use, in scorbutic affections; he also extols the application of it externally, in form of poultice, combined with chamomile flowers.

In order to obtain the expressed juice, the recent plant should be pounded in a marble mortar; the juice should then be squeezed through a coarse linen cloth by means of a press. 


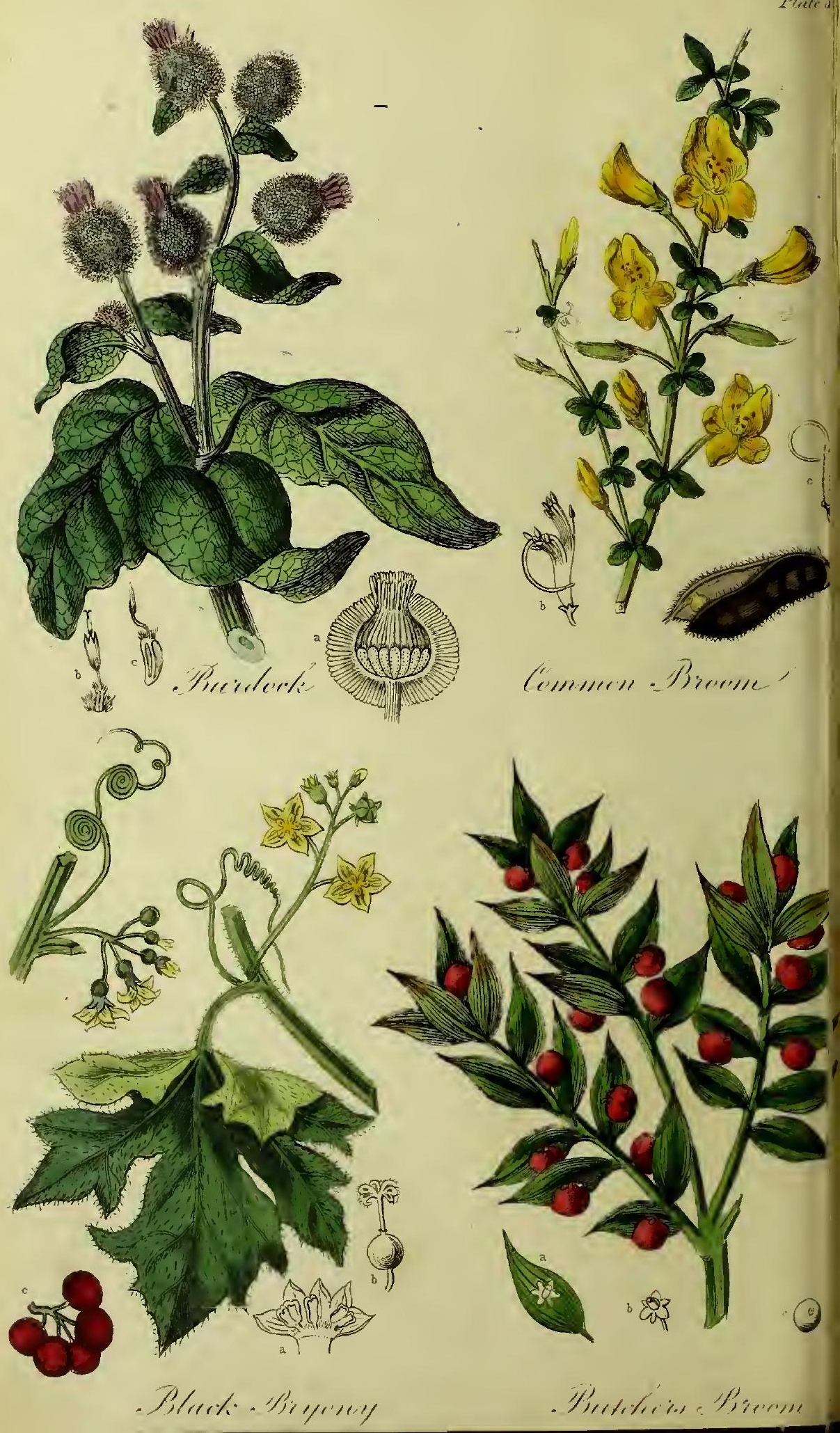




\section{XXVII. \\ CYTISUS SCOPARIUS.}

Common Broom.

Class XVII. Diadelphia,-Order III. Decandria.

Nat. Urd. Leguninose.

Gen. Char. Calyx two-lipped; the upper lip nearly entire; lower one three-toothed. Standard of the corolla ovate, large; keel very blunt, enclosing the stamens. Legume flattened, many-seeded.

Spec. Char. Branches angular, glabrous. Leaves ternate, stalked; upper ones simple; leaflets oblong. Flowers axillary, with short pedicels. Legume hairy at the margin.

\section{S Y N O N Y E S .}

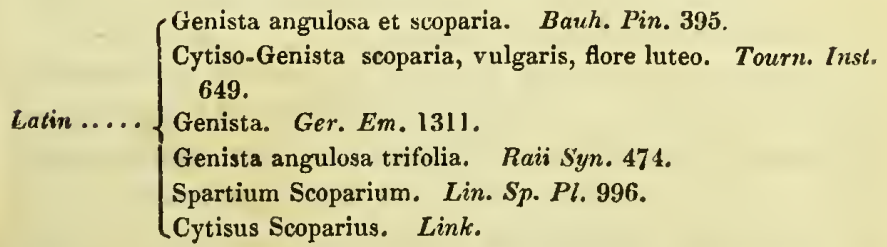

French... Genêt commun ; Genêt à balais ; Sparte commun.

Italian... Ginestra.

Spanish.... Ginesta ; Escoba ; Retama.

Portuguese Giesta.

German... Pfriemenkraut; Geniste; Genster.

Dutch .... Bezembren.

Belgic .... Brem; Brem-kappers.

Swedish ... Pings blomma.

Description.-The root is hard, woody, of a yellowish colour, and furnished with several oblique fibres. The stem is shrubby, ascending, angular, from three to eight feet high, and 
branched with numerous straight, flexible, long, angular, snıoth, evergreen twigs. The leaves are ternate and solitary, oblong, downy, and stand on footstalks of different lengths. The flowers are large, papilionaceous, bright yellow, axillary, solitary or in pairs, on simple peduncles longer than the leaves. The calyx is tubular, of a purplish colour, divided transversely into two lips, of which the upper is entire, or with two small teeth, the lower three-toothed. 'ithe corolla is composed of five petals; the vexillum or standard is large, broadly ovate, and reflexed ; the alæ or wings are elliptical, spreading, convex, and united with the filaments; the keel is formed of two petals, connected together at the maryin by soft hairs. The filaments are ten, nine of which are united at the base; unequal, incurved, and support oblong, orange-coloured anthers. The germen is compressed, oblong, hairy, supporting a slender, curved style, with an oblong stigma. The legume is flattened, oblong, hairy at the margin, of a deep brown colour, and contains numerous roundish, compressed, shining seeds. Plate 8 , fig. $2,(a)$ the calyx; (b) stamens; (c) the pistil; (d) the legume or pod.

This ornamental shrub grows abundantly in dry sandy pastures; flowering in May and June.

The generic name is formed from the xurbjos of the ancient Greeks ; said to have been so denominated from the isle Cythnos, one of the Cyclades.

Qualities and greneral Uses.-The Broom is applied to many useful purposes in domestic economy and agriculture. The flower-buds pickled in vinegar have been substituted for capers; and the roasted seeds have been proposed as a substitute for coffee. The young and tender branches are sometimes mixed with hops in brewing. At a little village in Tuscany, the stems of this plant steeped in the hot springs which occur in the vicinity, furnish a very strong fibre, which is manufactured into coarse cloth and cordage. In order to procure this substance, the branches are cut and laid in the sun; when they are quite dry, they are tied up in bundles and thrown into the water, being loaded with stones to make them sink, in the same manner as hemp. When the twigs are sufficiently soaked, they are taken out of the water and placed upon a sharp stone; the bark is then stripped off, and the fibrous part is well beaten; when dry it is carded and spun, and used for the 
same purposes as flax. 'The branches have also been used for tanning leather, for thatching cottages and ricks, to be made into besoms, and as a winter food for sheep. The old wood furnishes a beautiful material for veneering.

'The leaves and stalks of the common Broom have a nauseous and bitter taste, which they give out by infusion, both to water and rectified spirit; the latter infusion is of a dark green, and the former of a brownish colour. An extract prepared from the above possesses all the virtues of the plant.

Medical Properties and Uses.-Broom tops have been esteemed for a long period as cathartic and diuretic; they are most celebrated for the latter property. Dr. Mead* relates a case of dropsy, of which, after every other remedy had been tried in vain, the patient was cured by taking every morning and evening half a pint of a decoction of recent Broom-tops, with a spoonful of whole mustard. Dr. Cullen, speaking of this plant, says, "I found it first in use among our common people, but I have since prescribed it to some of my patients in the manner following: I order half an ounce of fresh Broom-tops to be boiled in a pint of water, till one half of this is consumed, and of this decoction I give two table-spoonfuls every hour, till it operates by stool, or the whole is taken: It seldom fails to operate both by stool and urine, and by repeated exhibition, every day, or every second day, some dropsies have been cured."

Sydenham, as well as many other eminent writers, particularly commend the alkaline salt obtained by burning the plant and passing water through the ashes, as a sperific in dropsy. It may be objected, that this is no other than'carbonate of potash, which may be obtained from the ashes of any other vegetable. It is true, that after repeated purifications, nothing but carbonate of potash remains, differing in no respect from that obtained from other vegetables; but this very purification may disperse the most valuable part, that is, the esssential oil of the plant, in which its medical virtue chiefly consists. For this reason the plant should be reduced to ashes by slow combustion in an iron pot, and a ley formed by passing water through these ashes which will dissolve the salt; this should be afterwards filtered throngh flannel, and then evaporated till the salt can crystallize 
on cooling. This, cliemically speaking, will be a very impure salt, but its efficacy will be greater than when purified.

This remedy has also been employed in chronic diseases of the liver and spleen. The flowers infused in hot milk have been applied to tetters and other obstinate cutaneous affections; the decoction being at the same time used internally. Ray mentions, that the seeds and flowers are reputed emetic and cathartic, which Woodville appears to doubt, because "the former when roasted have been used as a substitute for coffee, and the latter employed as a pickle." This objection is far from conclusive, when we reflect that the simple process of roasting or pickling is capable of dispersing even noxious qualities in many vegetables.

A Tincture of Broom-seed is recommended in dropsy, by Dr. Pearson, and is thus prepared:

Take of Broom seeds bruised, two ounces.

Rectified Spirit .... eight ounces.

Macerate for ten days and strain.

The dose is from one to two or three drachms daily, in any aromatic vehicle. 


\section{XXIX.}

\section{BRYONIA DIOICA.}

\section{Red-berried Bryony.}

\section{Class XXI. Monceia.-Order V. Pentandria.}

Nat. Ord. Cucurbitacee.

Gen. Char. Male flower: Calyx five-toothed. Corolla five-cleft. Filaments in three parcels.-Female flower: Calyx five-toothed. Corolla five-cleft. Style trifid. Berry succulent, globose, inferior, many-seeded.

Spec. Char. Leaves palmate, rough on both sides with callous points. Flowers diœcious.

SY NONY M ES.

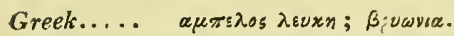

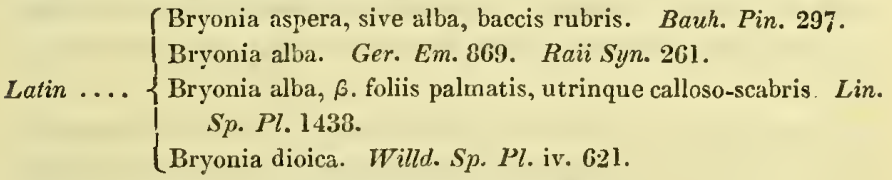

French.... Bryone; Vigne blanche; Couleuvrée.

Italian.... Brionia ; Fescera ; Vigna salvatica.

Spanish... Nueza.

Portuguese Horça branca.

German... Zaunrebe; Gichtrübe ; Stickwurz.

Dutch .... Bryonie; Wild Wyngaard.

Danish ... Galdebœr; Hundebœer.

Swedish .. Hundsrofva.

Polish .... Przestap.

Description.-The root is perennial, very large, fleshy, of a yellowish-white colour, marked with superficial transverse lines. fibrous and branched towards the lower part. 'ithe stems, which are generally five or six feet in length, are slender, herbaceous, branched, channelled, covered with small rough hairs, and 
climbing by means of numerous simple tendrils. The leaves are large, alternate, palmated, with five acute, irregularly toothed lobes, rough on both sides with minute callous points, and supported on long stalks, from whose base proceeds a long, simple, spiral tendril. The flowers are dicecious, disposed in small clusters, which spring from the axils of the leaves: the male flowers have a short, campanulate, five-toothed calyx, a monopetalous corolla, with five ovate, spreading segments, of a yellowish-white colour, elegantly streaked with green veins, and three short filaments, two of which are furnished with double anthers; the female flowers have a calyx and corolla, resembling those of the male, but smaller. The germen is inferior, one-celled, surmounted by a short, erect, three-cleft style, terminated by large, spreading stigmas. The fruit is a globose berry, one-celled, many-seeded, about the size of a pea, at first green, afterwards changing to a bright red colour. The seeds are about five or six in number, small, ovoid, compressed, and enveloped in a mucilaginous pulp. Plate 8, Fig. 3. (a) corolla spread open to show the anthers; $(b)$ germen, with its style and stigmas; $(c)$ ripe fruit.

This plant is a native of most parts of Europe; frequent in England, rare in Scotland. It occurs in hedges and thickets, flowering from May to August*, and ripening its fruit in autumn.

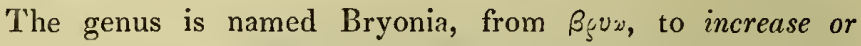
grow rapidly, in allusion to the quick growth of the plant. This species is called, provincially, Wild Vine, and Tetter Berry.

The red-berried Bryony was reckoned by Linnæus a variety of the Bryonia alba or White Bryony; but the latter has monœcious flowers and black fruit, and is more frequent in the northern parts of the continent.

According to Miller, the roots of Bryony were formerly carried about the country and exhibited as mandrakes by certain impudent impostors $\uparrow$, who thus reaped a golden harvest from

* The annual herbaceous stems of the male plant generally wither and die before the end of July.

† "Circulatores et Agyrtæ nonnulli ex hujus radice mira quædam monstra effingunt, quæ cum aliquot dies siccæ arenæ mandaverint pro mandragoris postea distrahunt et vendunt." Geoffroy, Mat. Med. iii. 224. 
the credulity of the common people. The mode by which they obtained a resemblance to the human figure was this:- they found a young, thriving Bryony plant, and opened the earth round it, taking care not to disturb the lower fibres, and being prepared with a mould, such as is used for making plaster of Paris figures, they fixed it close to the root, and fastened it with wires to keep it in its place, then filling up the earth carefully to the root, they left it to assume the prescribed figure. As it grows very rapidly, their object was generally accomplished in one summer. The leaves also werc sold for those of the mandrake, though they bear no resemblance to each other.

Qualities and general Uses. - The root of this plant scems to bear a considerable resemblance to that of Arum. In its recent state it has a very disagreeable odour, and a nauseous, bitter, acrid taste, and is undoubtediy poisonous; but the deletcrious principle may be so far dissipated by repeated washings with water, as to afford a fine and white fecula, capable of furnishing an alimentary substance, which in seasons of dearth is the more valuable, as the root is very abundant and very voluminous. Dioscorides informs us, that the young shoots may be eaten as asparagus, but he adds, they augment the quantity of the fæces and urine. The odour of the berries is slightly nauscous, and the taste insipid; a few of them have been eaten without any remarkable effect being produced, but in all probability they partake of the noxious qualities of the root.

A sibstance has been lately detccted by Brandes and Firnhaber in the root, to which the name of Bryonine has been given; besides which, the root contains a large portion of gum and starch, a little sugar, some woody fibre, malate and phosphate of lime, and a peculiar vegeto-animal matter. Bryonine is intensely bitter, soluble both in water and alcohol, and appears to be the active principle of the root from which it is derived.

The process used by M. Fremy to obtain Bryonine, consists in saturating the expressed juice of the root with ammonia, filtering the fluid, and evaporating it till a pellicle is formed on the surface. The pellicle is the impure Bryonine, which is to be purified by solution in alcohol. Twenty-two grains of this 
substance killed a rabbit in ten hours, and thirty-four grains thrust under the skin of the neck and back of a dog, killed it in fifty-eight hours, causing extensive inflammation and suppuration around the wound. Bryonine therefore is a pure irritant, which does not appear to act through absorption *.

Poisonous Properties. - The improper administration of the root of Bryony, has been followed by violent vomitings, accompanied with faintings, intense pain, profuse alvine evacuations, and the other effects of an acrid cathartic.

The following case of poisoning is recorded in a foreign periodical $\uparrow$. The writer says, "I was called a few days ago to the assistance of a lying.in woman, whose infant was dead, and to whom a surgeon in the village ordered a drink prepared with an ounce of Bryony root infused in a quantity of water, and a strong decoction of the same as a wash, to stop the secretion of milk. On my atrival, four hours after this remedy had been taken, she expired."

The treatment required, is nearly the same as that already mentioned under Aconite, Arum, and Bearsfoot. "The inflammation must be combated by emollient and mucilaginous drinks, and the usual antiphlogistic measures. If the nervous system be in a state of great excitement, recourse must be had to opiates and the different medicines which are capable of diminishing this excitement." Orfila.

Medical Properties and Uses. - The root has been long known as a powerful cathartic and diuretic, and the juice obtained from it by incision or otherwise, is a popular remedy in many countries. In Germany and Sweden, the peasants scoop out a portion of the root and fill the cavity with beer, which in the course of a night becomes emetic and purgative. The milky juice will exude for two or three days together in considerable quantity, and may be collected as the cavity becomes full. It was recommended by Dioscorides as a remedy in epilepsy. Arnaldus mentions a case of epilepsy which was cured by these means in three weeks. It has also been employed in dropsy, asthma, hysteria, and obstructions of the viscera, in the quantity of two or three spoonsful every morning. If it be found too

* Nouvelle Bibliothèque Médicale, May, 1:27.

+ Gazette de Santé, Dec. 1816. 
powerfully cathartic, Geoffroy advises cream of tartar or some aromatic to be added.

"I am convinced", says Gilibert, "by a series of experiments, that the root of Bryony is capable of furnishing all kinds of purgatives, from the laxative to the drastic. Several observations go to prove, that there is a species of mania depending on a vitreous, sliny matter, which lines the stomach and intestines; in these cases, the root, even in its recent state, has effected a cure by evacuating this substance." Other physicians place it on a par with jalap, and express their surprise that it is not more frequently used. Sydenham relates an instance of mania in which he found it efficacions. He gave a drachm of the powdered root in milk, or half an ounce infused in wine, three or four times a day; but in the case alluded to, blood-letting, both from the arm and jugular vein, was superadded. It was likewise esteemed emmenagogue*, and as a vermifuge $\downarrow$ it has been lighly commended. Its efficacy in dropsical cases is well authenticated : in these cases, an infusion of two drachms of the root in six ounces of water, sweetened with some aromatic syrup, has been given in the dose of a spoonful every two hours.

As an external application, Bryony enjoyed the character of a powerful discutient. It was applied in the form of a poultice to painful tumours, lumbago, and sciatica. Ettmuller recommends it in hydrocele and cedematous swellings of the feet and legs. Zacutus Lusitanus affirms that the expressed juice, made into an ointment with an equal quantity of turpentine and a small proportion of wax, has been known to cure scrofulous tumours.

For medical purposes, the root should be dug up in the spring, cut into thin slices, and dried quickly in a warm room; and as it does not long retain its virtues, even when preserved in close bottles, the quantity for use must be regulated by the length of time it has been kept. The infusion seems to be one of the best forms of the medicine, but others have been recommended, as-

" "Menses ac fætum pellit, ahortumque sæpe procurat."-Etmuller.

+ There are some extraordinary stories on record of its efficacy in expelling toads and frogs, and several nondescript animals, from the ab. domen. 


\section{SYRUP OF BRYONY.}

Take of Expressed juice of Bryouy root, one pint ;

Refined sugar ........... a pround and half.

Let the juice stand in a basin till the feculencies subside, then pour off the clear liquor and boil it with the sugar to the consistence of a syrup.

\section{EXTRACT OF BRYONY.}

Take of Root of Bryony, one pound ;

Spring water.. six pounds.

Macerate for four days in a warm place, then boil gently; filter and express the liquid, and evaporate the straining to the consistence of an extract.

DosE.-From five to fifteen grains.

The oxymel of Bryony, recommended in asthma and old coughs, may be prepared thus:

Take of Expressed juice of white Bryony (after the feculencies have subsided) one pint ;

Honey, a pound and half;

Vinegar, three quarters of a pint.

Simmer the whole together over a slow fire, carefully removing the scum as long as it rises, and when it has boiled a few minutes pour it off into an unglazed earthen vessel for use.

The Black Bryony (Tamus Vulgaris) is sometimes confounded with the plant just described. It is, however, quite distinct, belonging to the Dicecia, Hexandria of Linnæus, Smilacece of Jussieu. It has a small, greenish-white perianth, divided into six deep segments, in the female flowers contracted at the neck* ; ovate, shiningr, red berries; heart-shaped, acute, entirc leaves, of a bright green colour; very long, twining stems; and a large fleshy root, black externally. It flowers in June. Dr. Withering states, that the young shoots are good eating, dressed like asparagus. The Moors eat them boiled with oil and salt. The root, which very much resembles that of the Bryonia dioica, except in colour, has been extolled by some writers, whilc others deny that it possesses any medicinal virtues. Sir John

"Hence the name "Lady's Seal," and that of "Sigillum beata Virginis," by which the plant is designated in Gerard's Herbal, and in Lord Bacon's Sylva sylvarum. 
Hill affirms, that it is " a very powerful remedy in nephritic cases, though not known in the shops, or used in modern practice. The best method of giving it is, the expressed juice in white wine. This operates powerfully by urine, and has been found of great service in gravel, and, in smaller doses, in obstructions of the menses. A syrup made with it is useful in asthma, and the bruised root has given relief in paralytic cases." 
XXX.

MENYANTHES TRIFOLIATA.

Common Buckbean, or Marsh Trẹoil.

Class V. Pentandria.-Order I. Monogynia.

Nat. Ord. Gentianee.

Gen. Char. Calyx fire-parted. Corolla fumel-shaped; the limb spreading, five-parted, fringed internally. Stigma two-lobed. Capsule one-celled, two-valved; the valves bearing the seed in their axis.

Spec. Chak. Leaves ternate. Disk of the corolla fringed with shaggy hairs.

SY NO N Y E S.

Latin .... $\left\{\begin{array}{l}\text { Trifolium palustre. Bauh. Pin. 327. } \\ \text { Trifolium paludosum. Ger. Em. 1194. } \\ \text { Menyanthes palustre, triphyllum, \&c. Raii Syn. } 285 . \\ \text { Menyanthes tuifoliata. Lin. Sp. Pl. 208. }\end{array}\right.$

French.... Menyanthe ; Trefle d'eau.

Italian... . Meniante ; Trifoglio palustre.

Spanish ... Trifolio palustre; Trebol de pantano.

Portuguese. Trevos dos charcos; Trevo d'agua.

German ... Wasserklee; Bitterklee; Fieberklee.

Dutch .... Water Drieblad; Water Klaveren; Boks-boonen.

Danish .... Vandklever ; Bukkeblade.

Swedish ... Vattukloefver.

Polish .... Cwikla Lesna.

Russ..... Trilistnik.

Lapp. .... Krass.

Description.-The roots consist of numerous fibres, pros ceeding from a long, creeping, cylindrical, jointed rhizoma*. The stem is a simple, naked, cylindrical scape, rising about a

" "The root," in common language. 
foot in height. The leaves are radical, consisting of three smooth, obovate, obtuse, entire, bright green leaflets, somewhat undulated at the margin, and stand on a very long petiole, shorter than the flowcring stem. The flowers grow in a compound raceme or thyrse, at the cxtremity of a scape which issues from the sheathing base of the lcavcs; each flower supported on a pedicel, with a sinall, ovate, acute bractea at the base. The calyx is smooth, divided into five decp, ovatc segments. The corolla is funnel-shaped, longer than the calyx, with a spreading limb composed of five ovate-lanceolate, acute segments, which are white, fringed internally with beautiful filaments, and tipped with rose colou:. The five stamens have awl-shaped filaments, alternate with five hypogynous glands, and support sagittate anthers of a brownish ycllow colour. The germen is oval, surmounted by a simple style, longer than the stamen, and a capitate stigma, furrowed externaily. 'The capsule is oval, furrowed, one-celled, two-valved; the valves bearing the seed in their axis. The seeds are globose, or somewhat lenticular, smooth, shining, and of a pale yellow colour. Plate 7, fig. 4. (a) the corolla opened to show the stamens; (b) the fruit.

This most elegant plant is frequent in marshes and watery meadows, and on the margins of ponds and brooks. It may vie with many choice exotics in beauty, and if less abundant and not indigenous, would be assiduously cultivated. The flowers appear from the middle of June to the end of July. It is a denizen of the greater part of Europe, as far north as the inhospitable regions of Lapland, and in North America it occurs under equally diverse latitudes.

The generic name, is supposed to be derived from $\mu$ ry $v$, a month, and arfos, a flower, because it continues in flower about a month. It is called trifoliata, from the similarity of its three lcaflets to those of trefoil. They were also considered to resemble thosc of the common garden bean; hence, the vernacular names Buckbean, and Bogbean. The term Buckbean is probably an alteration of the old English beck, a brook, or watery place; or of the French bouc, a he-goat; the plant being eaten by goats.

Qualities and general Uses. - The Buckbean has no smell, but develops an intense bitterness, which it imparts both to al- 
cohol and water, either by infusion or maceration. The root affords a small portion of volatile oil, and a gum-resinous substance, which, in addition to its bitterness, exhibits considerable acidity and astringency; - this is not perceptible to the taste, but is rendered very evident by the dark colour produced in the decoction, by sulphate of iron. It also contains a small quantity of fecula, to which its nutritive properties are owing.

Linnæus informs us, that in some parts of Lapland, where the Buckbean abounds, the roots are dug up and given to cattle, who eat it freely, instead of their usual food. In times of scarcity, the dried and pulverized roots, mixed with a little wheaten flour, are not less useful as food for the distressed inhabitants of that country; but the bread thus made, is designated by Linnæus as very bitter and detestable. The peasants of Westrogothia frequently use the leaves instead of hops for preserving their beer, which is thus rendered of an agreeable flavour as well as defended from acescency. It has been recommended for the same purpose to the poor of this country; two ounces of the dried leaves being reckoned equivalent to a pound of hops. In dyeing, they afford, according to Bechstein, a green and yellow colour.

The Buckbean is eaten by goats, and occasionally by sheep. It has been asserted, that sheep affected with the disease called rot, are quickly recovered by feeding in the marshy meadows where this plant abounds.

Medical Properties and Uses.-Like most of the Gentianeæ and other bitter plants, the Buckbean acts as a powerful tonic on the animal economy, either by augmenting the vital energy of certain organs, or by more abundant secretions. Hence the detersive, diuretic, deobstruent, emmenagogue, and other propertias which have been attributed to it. Its exciting influence upon the stomach and intestines, when administered in a large dose, is such as to produce vomiting and purgations ; as observed by Willis, when it was given in powder to the extent of two scruples; but in a small dose its action is very different.

In many countries, especially in Germany, this plant has been used medicinally for a long period, and esteemed almost a panacea. Its efficacy has been extolled in mervous diseases, such 
as periodical headaches, hypochondriasis, palpitations of the licart, paralysis, \&c. Willis uscd it as a vermifuge for children, in the dose of half a drachm to one drachm every morning fasting, for scveral days together, which was followed by an abundant evacuation of intestinal worms. Simon Pauli, Dolœus, Willis, and others, have eulogized it more or less as a remedy in icterus and abdominal obstructions, uterine hæmorrhages, dropsy, cachexia, scrofula, and rheumatism. It has been lauded even in pulmonary consumption; its efficacy in intcrmittent fevcrs, however, is better authenticated. It has consequently been used as a substitute for bark, and as it grows in marslyy districts, where remittent and low fevers abound, it has been deemed by some as a specific in those diseases. Tlie celebrated Boerhaave, in his own casc of gout, found benefit from drinking the juice mixed with whey; and Dr. Alston and others bear witness to its efficacy in keeping off the gouty paroxysms. D1. Cullen relates, that "he had several instances of its good effects in some cutaneous diseases of the herpetic or seemingly cancerous lincl. It was taken by infusion in the manner of tca." Externally, it has also been variously employed. Schulz found the pain of gout mitigated by applying the fresh leaves to the part affected. The juice has bcen used as a detersive in scorbutic and other ulcers. 'The decoction has bcen administered in batlss and fomentations, in some chronic diseases of the skin. "But it must not be forgotten, that its application to ulccrated parts has been followed by swelling and inflammation; and its internal use by dyspnoa. And though these ill effects are soon dissipated by the suspension of the medicine, they form a sufficient reason for abstaining from it in plethoric subjects, in delicate and irritable habits, and in all diseases accompanied with inflammation." *

The leaves should be gathered in May and Junc, before the flowers are perfectly evolved, and being well dried, they may be preserved for use. The dose of the powder is from a scruple to a drachm; and the infusion may be made with half an ounce of the dried plant to a pint of water, milk, wine, or alcohol, to which some warm aromatic, as two drachms of ginger, 
should be added. A wine-glassful of this may be taken three or four times a day, according to circumstances.

The expressed juice may be given in the quantity of one to two ounces. The Parisian Codex orders a syrup and an extract to be made thus:

SYRUP OF BUCKBEAN.

Take of Juice of Buckbean, clarified by ebullition and strained;

White sugar; of each equal parts.

Boil to the consistence of a syrup by the aid of a gentle heat.

EXTRACT OF BUCKBEAN.

Take of liresh leaves of Buckbean, any quantity.

Express and clarify the juice; then evaporate in a sand-bath to the con. sistence of an extract.

The dose of the extract is from one to two scruples. 


\section{XXXI.}

\section{RHAMNUS CATHARTICUS.}

\section{Common Buckthorn.}

\section{Clelss V. Pentandria.-Order I. Monogynia.}

Nat. Ord. Rhamnes.

Gen. Char. Calyx urceolate, four to five cleft. Petals four to five, or wanting. Stamens opposite the petals. Germen superior, three or four celled. Berry two to four celled, two to four seeded.

Spec. Char. Spines terminal. Flowers four-cleft, diœcious. Leaves ovate, sharply serrated. Berry with four seeds.

S Y NON Y M ES.

Greek..... p. pupyos. Dioscorides.

Latin .... $\left\{\begin{array}{l}\text { Rhamnus catharticus. Bauh. Pin. } 478 . \text { Raii Syn. } 466 . \\ \text { Rhamnus solutivus. Ger. Em. 1337. } \\ \text { Spina infectoria. Matth. } 158 . \\ \text { Rhamnus catharticus. Lin. Sp. I'l. } 279 .\end{array}\right.$

French.... Nerprun; Noirprun; Bourg-epine.

Italian.... Spino cervino; Spinamagna.

Spanish ... Espina de ciervo; Cambron; Ramno catartico.

Portuguese.. Escambroeiro; Espenheiro cambra.

German ... Gemeine Kreuzdorn; Kreusbeeren-strauch; Wegdorn.

Dutch ..... Wegedoorn; Rhynbezien-doorn.

Swedish.... Gettapel; Saftgrœnt.

Danish.... Korsbœr; Vrietorn.

Polish.... Szaklak Krzewina.

Russian ..... Schest.

Description.-This shrub rises to the height of eight or ten feet, with a strong upright stem, much branched and spreading, the branches terminating in a sharp spine after the first year; the 
wood is of a yellowish colour, and covered with a smooth, darkbrown bark. The leaves are alternate, simple, ovate, petiolate, downy when young, subsequently smooth, finely serrated, of a deep green colour, and marked with parallel and convergent nerves; the serratures glandular. The flowers are diœcious, (the male and female being seldom found on the same plant,) of a greenish yellow, arranged in dense fasicles in the axils of the leaves; each small flower supported on a slender pedicel : the male flower has a campanulate calyx with four ovate segments and four oblong-ovate petals, at the base of which the five stamens are inserted: the female flower has four linear, incurved petals, abortive stamens, an inferior germen, and four spreading styles, united half way up, and terminated by a small stigma. The fruit is a small, globose, black berry, containing a nauseous pulp, and generally four seeds, which are ovate, rounded at the back, and flattened at the sides. Plate 10, fig. 2. (a) male flower; (b) female flower; (c) ripe berry.

'The Buckthorn is a spreading shrub, with a pleasant foliage, frequent in woods and hedges in many parts of England; abolit Dumfries in Scotland; near Cork and Lough Earne in Ireland. The flowers appear in May and June, and the purplish-black berries ripen in September.

The generic name is derived from the Latin, ramus, which was formed from the Greek, pxuvos, and that from the Celtic, ram, a branch.

There is another species indigenous to Britain, the Alder Buckthorn, ( $R$. Frangula, which is unarmed, with perfect flowers, and ob-ovate entire leaves; the berries are dark purple, and contain two seeds. Gathered before they are ripe, they dye wool green; when ripe, a blueisl green. The bark has been used in medicine as a purgative, and affords a yellow dye. The leaves are eaten by goats and sheep; the flowers are peculiarly grateful to bees.

There are about sixty foreign species, of which the most interesting are, the box-thorn-like, ( $R$. Lycioides), of which the Mongols make their images on account of its hardness and beautiful orange-colour; the yellow-berried Bucktlorn, $(R$. infectorius, ) whose fruit is known in commerce by the name of Avignon berries, from which the pigment called sap-green is obtained; the Tea Buckthorn, (R. Theezans, which has leaves 
like the common tea, and is used as sucl by the poor of China, who call it Tia; the Rock Buckthorn (R. Saxatilis, ) the berries of which give the yellow dye to morocco leather; the common Alaternus, (R. Alaternus, ) an ornamental evergreen; and Rhamnus spina Christi, of which it is supposed the crown of thorns put upon the head of Jesus Clirist was composed.

Qualities and general Uses. - The unripe berries of the comnion Buckthorn yield a saffron-coloured juice, which is used to stain maps or paper. From the ripe berries sap-green* (vert de vessie, Fr.; Saftegrün, Ger.) is obtained, nearly equal to that prepared from the Avignon berries; but if the fruit is gatlered late in autumn, the juice is purple. The wood furnishes an excellent material for turnery, and the bark affords a yellow and brownish red colour. Goats, sheep, and horses eat the leaves, but cows refuse them. Homberg \& mentions that the flesh of birds which feed on the berries is purgative, but this statement needs to be confirmed.

The ripe berries contain a green succulent pulp, of an unpleasant odour, and a bitter, nauseous, and somewhat acrid taste. The aqueous infusion is reddened by nitric and sulphuric acid, and is rendered black by sulphate of iron. The berries yield a colouring matter, as already mentioned, of a greenish yellow colour, which is found in the fruit of many other rhamnece, and is thought to contain tannin, albumen, acetic acid, sugar, and an azotized substance.

Medical Properties and Uses.-Buckthorn berries have been nsed medicinally from time inmemorial as a drastic purgative. They do not operate, however, without producing severe griping, with dryness in the throat, which require considerable dilution to obviate; on which account they are seldom used in modern practice. About twenty of the fresh berries constitute a proper dose, if taken in that form; which is only proper for very robust subjects. The most convenient as well as pleasant method of taking this medicine is in the form of a syrup prepared from their juice, which has been highly com-

This colour may be made by adding twelve ounces of lime-water, and a small quantity of gum arabic, to every pound of the expressed juice, which is to be evaporated to the consistence of an extract, and dried for use.

† Mémoires de l'Acarl des Sc. de Paris, 1712, p. 9. 
mended for carrying of serum in dropsies of every kind, and as a purgative in cachectic and hypochondriacal diseases, scrofula, chronic diseases of the skin, and after the suppression of any habitual evacuation. It has been found useful in gout, for which disease, as well as dropsy, it was frequently prescribed by Sydenham. This acute physician, however, did not overlook the thirst and dryness of the throat produced by it; and therefore ordered a basin of soup to be taken immediately after it to obviate these effects. It is directed by the London Pharmacopœia to be prepared as follows, the aromatics being added to prevent its griping effects.

\section{Syrup of Buckthorn.}

Take of Fresh juice of Buckthorn berries, four pints ;

Ginger root sliced, Pimento berries bruised, of each half an ounce; Refined sugar, three pounds and a half.

Set apart the juice for three days, that the fæces may subside, and strain it : to a pint of the strained juice, add the ginger root and pimento, then macerate by a gentle heat for four hours and strain. Boil the remainder of the juice down to a pint and half, then mix the two liquors, and add the sugar in the manner directed for making syrups.

The dose is from four drachms to an ounce, drinking freely of gruel, or other tepid fluids, during its operation.

The medical properties of the bark of this shrub do not appear to have been sufficiently investigated, if we may rely on the authority of Dr. Kolb, of Erlang, who recommends it as an efficacious remedy, in every respect superior to the berries. He attributes to it tonic, gently astringent, and antiseptic properties, and recommends a decoction of it in powder, combined with honey, gum arabic, or some other mucilage, as beneficial in intermittent and other fevers, and in general debility after chronic diseases. He also extols the decoction of the bark as of great service in reducing inveterate inflammation of the eyes, and in some obstinate cutaneous diseases. Both the common and the Alder Buckthorn are frequently employed in veterinary practice as brisk purgatives for cattle. The berries of the latter are thought to be inferior to those of the former, for which they are sometimes substituted, but the frand may be discovered by opening the berry, which in the common Buckthorn contains four seeds, in the Alder Buckthorn only two. 


\section{XXXI1.}

\section{AJUGA REPTANS.}

\section{Common Bugle.}

Class XIV. Didynamia.-Order I. Gymnosfermia.

Nat. Ord. Labiate.

Gen. Char. Calyx orate, five-cleft, nearly equal. Corolla tubular, labiate; upper lip short, erect, entire or emarginate; the lower one patent, trifid, with a large intermediate obcordate lobe. Stamens ascending, protruded above the upper lip.

Spec. Char. Nearly smooth. Stem solitary, with creeping runners.

\section{SY NON Y MES.}

Latin..... $\begin{aligned} & \text { Consolida media pratensis. Bauh. Pin. } 260 . \\ & \text { Bugula. Raii Syn. 245. Ger. Em. } 631 . \\ & \text { Ajuga reptans. Lin. Sp. Pl. 785. }\end{aligned}$

French.... Bugle; Bugle rampante; Petite Consoude,

Italian ... Bugola.

Spanish ... Bugula.

German ... Weisergünzel ; Kriechender ; Günzel.

Dutch .... Zenegroen; Ingroen; Bugula.

Description.-The root is perennial, slender, very fibrous, of a greyish colour, and sends forth creeping scions. The flowering stem is erect, simple, quadrangular, smooth or somewhat downy, and rises about six inches in height. The leaves are opposite, ovate, somewhat crenate, more dense towards the root, broad, and tapering into a footstalk. The flowers are purplish blue, (sometimes white or flesh-colour), nearly sessile, disposed in whorls rising from the axils of the bracteæ, which are often purplish. The calyx is short, persistent, monophyl. 
lous, with five nearly equal, pointed segments. The corolla is monopetalous, irregularly labiate; the upper lip short, erect, composed of two very small teeth; the lower one, larger, spreading, with three lobes, the middle lobe emarginate, ample. The filaments are incurved, longer than the upper lip, didynamous. The germen is superior, four-lobed, deressed in the centre, surmounted by a simple incurved style, terminated by a bifid stigma. The fruit consists of four ovateoblong grains situated in the bottom of the persistent calyx. Plate 9, fig. $1,(a)$ an isolated flower; $(b)$ the calyx; (c) the piștil.

This pretty vivacious plant abounds in moist meadows and woods in Great Britain. It is also found in France, Holland, Germany, Poland, Denmark, and other European countries. It flowers from the end of April to the beginning of June.

'I'he derivation and meaning of the term Ajuga have somewhat puzzled etymologists. Some have derived it from abigo *, to drive away, or from a privative and jugum, a yoke. The common name, Bugle, is taken from Bugula, which is supposed to be a diminutive of Buglossum, which this plant somewhat resembles in medical properties.

Qualities and general Uses.-The economical uses of this plant are few. The Italians are said to eat the young shoots, in spring, as a salad.

Sheep and goats eat it, horses and swine refuse it. Brugmans considers it hurtful in meadows, but he does not state for what reason.

The leaves are sweetish to the taste at first, subsequently rather bitter and astringent. The root manifests a slight astringency and a strong infusion is rendered black with sulphate of iron.

Medical Properties and Uses.-This plant, though long banished from the pharmacopœias, was highly extolled by some of the ancient physicians, and is still occasionally resorted to in rustic practice. It is well described by the author of the Flore

* If so, it must be received in the same way as lucus a non lucendo, for the ancients gave it just the opposite character. They thought it efficacious in consolidating injured parts, or constringing the wounds of bloodvessels (hence the French name "Petite Consoude"). 
Medicale as follows. "The more we examine the feeble qualities of bugle, the more we are astonished to see it occupy an eminent place in the ancient pharmacologias. Etmuller and Riviere deemed it efficacious in pulmonary phthisis and quinsy; Camerarius and Dodæus prescribed it in obstructions of the liver; Mauchart gave it a place in his eau viscerale. It has been recommended, says Fourcroy, in hæmorrhages, spitting of blood, emaciation, and dysentery, and the name of petite consoude has been given it, because it was thought capable of soldering, if we may so speak, the wounds of blood-vessels. The bruised leaves were applied to ulcers, cuts, and contusions; they were also an ingredient in the eau d'arquebusade. The more scrutinizing observations of the present day, however, have stripped the Bugle of all its renown. Indeed, far from enjoying any preeminence, it is less valuable than some of the commonest labiata. Its distilled water, says Gilibert, is no better than common water, and this much vaunted vulnerary only cures wounds which nature would soon have healed without any assistance."

A strong infusion of the plant mixed with a little honey of roses has been recommended in ulcers of the mouth and throat. This perhaps is of no great value, but as the plant is very common it may be worth the trial. 


\section{XXXIII.}

\section{ANCHUSA OFFICINALIS.}

\section{Common Bugloss.}

Class V. Pentandria.-Order I. Monogynia.

Nat. Ord. Boragineer.

Gen. Char. Calyx five-cleft, or five-parted, persistent; tube straight, its mouth closed with five prominent scales. Anthers included. Stigmas emarginate. Nuts concave at the base.

Spec. Char. Leaves oblong-lanceolate, strigose. Spikes crowded, unilateral. Bracteæ ovate-lanceolate, as long as the calyx.

\section{S Y N O N Y M E.}

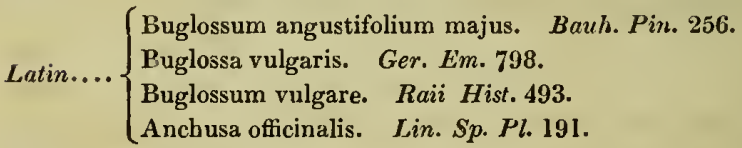

French..1 Buglosse.

Italian. - Buglossa.

Spanish. . Buglosa.

German.. Ochsenzunge ; Gewöhnliche ochsenzunge.

Dutch... Ossetong

Swedish . Oxtunga.

Description.-The root is perenaial, oblong, branched, about the thickness of the finger, of a reddish brown colour externally, nearly white within, succulent and inodorous. The stem, which rises to the height of nearly two feet, is covered with thick rough hairs. The leaves are alternate, oblong-lanceolate, entire, and clothed with hairs, each of which proceeds from a hard white tubercle. The flowers are disposed in unilateral, 

crowded, terminal spikes. The caly $\mathrm{x}$ is persistent, monophyllous, with five deep, oblong, acute segments. The corolla is purplish blue, monopetalous, funnel-shaped; the month of the tube closed with five bearded scales; the limb spreading, divided into five rounded segments. The five stamens are short, alternate with the scales, and terminated by oblong anthers. The germen is divided into four rounded lobes, from the centre of which rises a simple filiform style, tipped with a bifid stigma. The fruit consists of four oval wrinkled nuts, concave at the base, fixed to the bottom of the calyx. Plate 9 , fig. $2,(a)$ calyx; (b) corolla; (c) the same opened to show the stamens and valves ; $(d)$ the pistil.

The common Bugloss is a native of the northern parts of Europe. It can scarcely be considered indigenous to this country, but is occasionally met with in waste ground, especially near the sea. Dr. Hooker mentions Harley Pans, Northumberland, and Kilsyth, Arnbrae, and Addington in the vicinity of Glasgow, as its localities. It flowers in June and July.

It was formerly called Buglossum, hence the English name Bugloss, and its synonymes in many other languages, from Bous, an $o x$, and $\gamma \lambda \omega \sigma \sigma \alpha$, a tongue, in allusion to the long rough leaves.

Qualities ANd General Uses.-According to Linnæus, the tender leaves of borage afford a wholesome and nutritious food, and are often boiled and eaten like cabbage, in Uplandia, a province of Sweden; and it is said, in some parts of Italy. The leaves are juicy and the roots mucilaginous. Animals in general will feed on the plant. The juice of the corollas*, boiled with a small quantity of alum, affords a green colour. 'The flowers are melliferous, and very attractive to bees.

Medical Properties and Uses.-This plant bears a very striking analogy in its properties to borage, for which it is often substituted. They equally abound in a viscous juice, and yield a large proportion of nitre $\uparrow$; and both were highly extolled by the therapeutists of old as cordials, tonics, and exhilarants. They were reckoned particularly serviceable in melancholy and hypochondriacal diseases, and in inflammatory complaints,

* Linneus mentions the corollas, Willemet the leaves, as affording a fine green colour.

† Or more properly " nitrate of potass," hence their diuretic property. 
such as pleurisy and peripneumonia. Indeed the juice of them combined, obtained by expression and clarified, in the dose of four or five ounces at a time, was considered an absolute specific in pleurisy. Ray considered them to possess anti-epileptic virtues, and Chomel states that he found a decoction of the leaves useful in dysentery.

Bugloss is not yet banished from the Parisian and some other pharmacopoias; an infusion, a conserve, and a distilled water are directed to be made with the flowers.

A preparation made from the root of this plant is used by the Chinese, for promoting the eruption of the small-pox. 


\section{XXXIV. \\ ARC'TIUM LAPPA.}

Common Burdock.

Class XIX. Singenesia.-Order I. Polygamia Equalis. Nat. Ord. Composimæ.

Gen. Char. Involucre globose, imbricated; scales ending in a soft spine hooked at the end. Receptrcle chaffy. Pappus simple.

Spec. Char. Leaves cordate, stalked.

\section{SY NON YMES.}

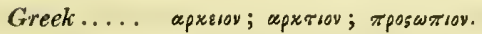

Latin .... $\left\{\begin{array}{l}\text { Lappa major. Bauh. Pin. 198. } \\ \text { Bardana major. Ger. Em. 809. Raii Hist. } 332 . \\ \text { Personata sive Lappa major. Matth. } 1154 . \\ \text { Arctium Lappa. Lin. Sp. Pl. 1143. } \\ \text { Lappa glabra et tomentosa. Lind. Syn. 154. }\end{array}\right.$

French.... Bardane; Glouteron.

Italian... Bardana ; Arsio ; Lappa maggiore ; Lappola magyiore.

Spanish.... Bardana; Lapa; Lampazo.

Portuguese. Lappa.

German.... Klette; Rossklette ; Klettenkraut ; Klettendistel.

Dutch. ... Klissen; Klassen; Klitten; Kladd-wortel.

Danish.... Agerbœrre; Agerskreppe; Storskreppe.

Polish .... Lupian.

Russ..... Lapuschnik.

Swedish.... Karborre.

Description.-The root is biennial, thick, long, cylindrical, fusiform, brownish externally, white within, somewhat branched and fibrous towards the base. The stem is herbaceous, annual, branched, striated, sometimes tinged with purple, and rising three or four feet in height. The lower leaves are very large, alternate, cordate, petiolate, toothed, or somewhat crenate at the margin, green above, slightly cottony beneath; they gradually 
decrease in size towards the top of the stem, so as to be nearly ovate. The flowers, supported on short peduncles, are purplish, and more numerous towards the top of the stem. The involucre $^{*}$ is globose, greenish, composed of imbricated, lanceolate scales, each of which terminates in a long, soft spine, hooked at the end. The florets are surrounded by the involucre, and seated on a paleaceous receptacle. The corolla is furnislied with a long slender tube, and a regular ovate limb, divided into five linear spreading segments; filaments hairlike, very short; anthers forming a cylindrical tube, as long as the corolla. Germen oblong, downy; style filiform, longer than the stamens; stigma reflexed. Fruit of many solitary, oblong, brown, angular grains, crowned with a simple and short pappus. Plate 8 , fig. $1,(a)$ involucre cut through vertically, showing the situation of the fruit ; $(b)$ floret of the natural size ; (c) isolated fruit or achenium.

This plant occurs abundantly in almost all climates, by road sides and waste places, flowering in July and August.

The generic name is derived from apxros, a bear, in allusion to the roughness of the fruit. It is well known in rural districts by the name of bur and clot-bur, from the singular manner in which its hooked bristles $\uparrow$ adhere to every object with which they come in contact; hence the specific name Lappa, from $\lambda \alpha$ Belv, to lay hold of, or as some think, from llap, a hand, in Celtic.

The stems of Burdock before the flowers appear, stripped of their outer rind, have been proposed as a substitute for asparagus, or to be eaten with vinegar and the yolk of eggs, in the form of a salad. The root contains a saponaceous substance, which has been advantageously employed in washing; pure starch has been obtained from it; and the ashes produced by burning the plant green, between the period of flowering and seeding, yield a large proportion (nearly one part in three) of

* It is generally smooth, but there is a variety whose involucre is covered with a cottony down, and is considered a distinct species by some botanists, under the name of Arctium Bardana, Willd., or Lappa tomentosa, Allioni.

+ Boys in the country have a method of catching bats by throwing up the tenacious involueres of this plant, whitened with chalk, in the way of their flight ; the bats, attracted by the object, hasten towards it, entangle their membranous wings in its hooked bristles, and are thus brought to the ground. 
very pure subcarbonate of potass. Schœffer fabricated a greenish white paper from the outer rind of the stem. Few quadrupeds browse upon this plant, except the ass, and occasionally kine and goats; birds feed on the seeds, and snails and caterpillars on the leaves.

Virgil* recommends it to be extirpated from meadows in which sheep are fed, as it lessens the quantity of their wool.

Besides the subcarbonate of potass already mentioned, it is said to yield salts of nitre, and a large quantity of inuline. The roots have a sweetish taste at first, followed by a slight austerity and bitterness; their juice slightly reddens litmus paper. The leaves and seeds are bitter, with a slight acridity; the bitterness of the seeds appears to reside in the integuments, the interior being of a farinaceous and oily nature.

Medical Propefties and Uses.-The Burdock enjoyed great reputation formerly as a detergent, diuretic, and diaphoretic, and it appears to be far from inert, though not often used in the present day. Ancient authors, as usual, are very loud in its praise. Simon Pauli $\uparrow$ extols its effects in lues venerea, especially in patients already emaciated, or of very delicate constitutions. Henry III., King of France, according to Riverius + , was cured of this disease by Petrus Pena, who administered to him a decoction of the root; Cæsalpinus found the same decoction usefill in cases of bloody and purulent expectoration; and Forestus mentions a case of gout cured by this remedy, in which the urine was not only greatly increased in quantity, but was rendered as white as milk. Sir John Hill § considered it quite a specific in gout, to which disease, however, he at last fell a victim. Similar praise is bestowed upon it as a remedy in calculous and gravelly disorders. Lieutaud || relates an instance of its efficacy in obstinate rheumatic pains. An ounce and a half or two ounces of the root were boiled in eight ounces of water, until one half was consumed, half an ounce of loney

* :Si tibi lanicium curæ ; primum aspera sylva,

Lappæque, tribulique absint : fuge pabula læta."-Georgic iii.l. 384.

† Quadripart., p. 402.

$\mp$ Riverius, Obs. 11, p. 312.

§ Management of the Gout, with the virtues of Burdock. 7th ed. London, 1771 .

|| Syn. Prax. Med.p. 563 
was then added, and this mixture was taken every morning, in bed, for four or five weeks. The same author asserts its utility in promoting the lochial discharge.

Externally, the leaves of the Burdock have been found extremely resolutive as an application to indolent tumours, and have been used with success by empirics to certain swellings of the knee joint, which had excited the greatest alarm. The manner in which it has usually been applied by many of these characters, has been by boiling the leaves in urine and bran, and forming them into a poultice to be applied to the part morning and evening. This is unquestionably a powerful, though not very elegant application; but the case of white swelling of the knee joint will warrant a little deviation from the ordinary form of prescription. Chomel * speaks very highly of it, applied as above.

The brinsed leaves, or the rasped root, are found an excellent application to foul sloughing ulcers, and also to certain obstinate and foul cutaneous eruptions. Etmuller commends the application of them hot, to parts affected with the gout, and to bruises where there is much extravasation of blood.

Hufeland $\nmid$ recommends the juice of the leaves as an application to ulcers. "M. Percy greatly lauds a species of nutritum, prepared with two ounces of the juice of the leaves, and the same quantity of oil, which are to be triturated and agitated in the cold, with several balls of lead, in a tin vessel: a green pomade is the result, containing a little oxide of lead, and also partaking of the properties of the juice. The majority of atonic ulcers of the legs, in general so stubborn, are soon healed by the application of a pledget dipped in this ointment, and above it a leaf of the Burdock; it mollifies their callous edges, and promotes suppuration; it has also been applied with success to open scrofulous tumours, and even to cancers, of which it hinders the progress and mitigates the pain." +

Decoctions of the Burdock root, says Withering, are esteemed by judicious physicians as equal, if not superior, to sarsaparilla. Dr. Woodville $\oint$ says, "as a diuretic, we have known it succeed

* Histoire abregée des Plantes Usuelles, t. i. p. 318.

+ Stirp. Helv. n, 181.

† Dictionaire des Sciences Med. tom. iii. p. 13.

$\S$ Medical Botany, vol. i. p. 42. 
in two dropsical cases, where other powerful medicines had been ineffectually used: and as it neither excites nausea, nor increases irritation, it may occasionally deserve a trial, where other active remedies are improper."

The powdered root is given in the dose of a scruple to a drachm, several times a day. The fresh juice of the leaves has been prescribed to the extent of two or three ounces. The decoction is thus made:

\section{DECOCTION OF BURDOCK.}

Take of Dried root of Burdock, one ounce ;

Boiling water ...... two pints.

Boil down to one half.

The whole of this, when intended as a diuretic, should be taken within twenty-four hours. 


\section{XXXV. \\ PIMPINELLA SAXIFRAGA.}

Common Burnet-Saxifrage.

Class V. Pentandria.-Order II. Monogynia.

Nat. Ord. Compositr.

Gen. Char. Caylx an obsolete margin. Petals obcordate, emarginate, inflexed. Fruit contracted at the side, ovate, crowned with the swollen base of the reflexed styles. Carpels with five filiform, equal ridges, of which the lateral ones are marginal. Channels with many vittæ. Seeds gibbous, flattish in front. Involucres none.

Spec. Char. Radical leaves pinnate, with roundish, sharply serrate, or lobed leaflets; those of the stem bïpinnate, linear.

\section{S Y NON Y M S.}

Pimpinella Saxifraga major altera. Bauh. Pin. 160.

Bipinella, sive Saxifraga minor. Ger. Em. 1044.

Latin...... Pimpinella Saxifraga minur foliis Sanguisorbæ. Raii Syn. 213.

Pimpinella Saxifraga. Lin. Sp. Pl. 378.

French..... Boucage; Boucage-Saxifrage ; Bouquetin.

Italian..... Pimpinella bianca.

Spanish.... Pimpinela blanca.

Portuguese .. Pimpinella blanca.

German.... Steinbibernelle; Rossbibernelle.

Dutch...... Kleine Bevernel ; Bevernaart.

Danish..... Steenbrekke ; Biergroed ; Pimpinelle.

Polish ..... Biedrznyniec.

Swedish .... Backrot.

Description.-The root is perennial, long, cylindrical, fusiform, whitish, somewhat fibrous, and marked with annular 
stria. The stem is erect, round, striated, pubescent when the plant is in flower, afterwards smooth, jointed; a little branched towards the top, and rising from a foot to eighteen inches in height. The leaves are variously shaped; those of the root are pinnate, composed of from five to seven rounded and more or less toothed leaflets, the terminal one often three-lobed; they soon wither, and are rarely found after fructification las commenced: the cauline leaves are bipinnate, with linear acute segments. The flowers are disposed in terminal umbels, flat, drooping before flowering, and consist of several radii, without involucre either general or partial. The calyx forms merely an obsolete margin. The corolla is white, composed of five inversely heart-shaped or somewhat ovate petals, inflexed at the point. The five filaments are white, spreading, filiform, and furnished with roundish anthers. The germen is ovate-oblong, striated, supporting two short styles terminated by simple, globose stigmas. The fruit is contracted at the sides, ovate, striated, and crowned with the swollen base of the reflexed styles; the carpels* are marked with fine, slender, equal ridges, of which the lateral ones are marginal. The seeds are gibbous, and nearly flat in front. Plate 9, fig. 3, (a) floret magnified; (b) the fruit.

This plant is a native of Great Britain, growing abundantly in dry, gravelly, or chalky pastures. It is found throughout the greater part of Europe, from the Mediterranean as far as Lapland, in which country it occurs, thougl rather sparingly. It flowers in July and August.

The generic name, Linnæus informs us, is altered from $b i$ pennula, twice-pinnated. The great variety in the form of the leaves occasions a resemblance between them and those of many other plants; hence the specific name Saxifraga, and the common name Burnet-Saxifrage, from their similarity to those of the Common Burnet (Salguisorba officinalis).

There is another British species, the great Burnet-Saxifrage, (Pimpinella magna,) which grows in woods and shady places, and is like the foregoing in habit, but it is larger in all its parts, and the upper leaves are much broader and less divided. The Anise, (Pimpinella Anisum,) well known for its aromatic and 
carminative properties, is not indigenous to Britain, but is sometimes cultivated in gardens; its seeds are annually imported in great quantities fronı Spain and Malta. A variety of the plant now before us is found in some parts of Prussia and Germany, which yields an essential oil of a fine blue colour, which it imparts to brandy; the juice of the root is likewise blue.

Qualities and general Uses. - The young leaves and shoots of this plant are said to be very palatable, and are eaten as salad; small bunches of them tied together, and suspended in a cask of beer or ale, impart to it an agreeable aromatic flavour; and it is asserted that they tend to correct tart and spoiled wines. Almost all quadrupeds will feed on this plant, and it is reputed to be a wholesome fodder for cows, and to increase their milk. It has been used externally to remove freckles.

The root has a strong unpleasant smell, and a warm, pungent, and bitterish taste, which is considerably diminished by drying or on being long kept. Its virtues are partially extracted by water, and completely by rectified spirit. When large quantities of the root are distilled with water, a small quantity of essential oil, extremely acrid and fiery, may be obtained *

Medical Properties and Uses. - Bergius states the virtues of this root to be resolvent, diaphoretic, stomachic, and diuretic $\downarrow$. Boerhaave found it extremely useful in dropsical and asthmatic complaints. Hoffman $\downarrow$ asserts that it is an excellent emmenagogue; and it is recommended by several writers in cases where pituitous humours are thought to prevail, such as catarrhal coughs, hoarseness, and humid asthma, but particularly in a symptomatic sore throat, called angina serosa. The German physicians have used it for removing tumours and obstructions of the glands, and in scorbutic and cutaneous disorders in general. The root has also been used as a masticatory in toothache, and to stimulate the tongue when that organ becomes paralytic . The powdered root was formerly united with arum, being considered an acrid stimulant.

* Lewis's Mat. Med. p. 502.

+ Mat. Med. p. 230.

$\ddagger$ Med. Off. p. 533 .

$\S$ Murray, App. Med. Vol. I. p. 425. 
It is given in substance in doses of a scruple, and, in infusion two drachms. The Germans have a tincture which is thus made :

TINCTURE OF BURNET-SAXIFRAGE.

Take of Root of Burnet-Saxifrage, sliced, five ounces.

Rectified Spirit ............ two pints.

After sufficient extraction, express and filter.

Dose, from thirty to forty drops, or more. 
XXXVI.

\section{RUSCUS ACULEATUS.}

Common Butcher's-Broom.

Class XXII. Diøcia.-Order III. Triandria.

Nat. Ord. Smilaceer.

Gen. Char. Male flowers: Perianth of six leaves. Filaments combined at the base; anthers three to six. Female flowers: Perianth of six leaves. Nectary tubular. Style one; stigma simple. Berry superior, three-celled; cells two-seeded.

Spec. Char. Stem branched, rigid. Leaves ovate, sharppointed, bearing the solitary flower on the upper surface.

\section{SY NONYMES.}

Greek.....

Ruscus. Bauh. Pin. 470. Raii Syn. 262.

Latin...... Ruscus, sive Bruscus. Ger. Em. 907.

Myrtacantha. Lob. ic. I. 637.

Ruscus aculeatus. Lin. $S p . P l .1474$.

French .... Houx frelon; Fragon piquant; Petit Houx.

Italian.... Rusco.

Spanish.... Brusco.

German..... Stechlicher Mausdorn; Mausdornbusch; Myrtendorn.

Dutch...... Muisdoorn.

Bohemiar... Lesnj myrtus.

Danish.... Musetorn.

Russ........ Menschoi myscheitern.

Description.-The root is perennial, thick, twining, and sends out fibres like that of asparagus : the plant itself is biennial, and, for one winter, evergreen. The stems are cylindrical, furrowed, smooth, flexible, dark green, rising from a foot to eighteen inches in height, and die down to the root after the 
fruit is ripe. 'The leaves are alternate, ovate, sessile, sharp-pointed, smooth, very rigid, and pungent, bearing the solitary flower on their upper surface. The flowers are diœcious, small and white, each rising on a slender foot-stalk from the bosom of the leaf. The males have an inferior perianth of six leaves, filaments combined at the base, terminated by three spreading anthers, seated on the edge of a tubular coloured nectary: the females have a perianth and nectary, as in the male; the germen is superior oblong, supporting a short, thick style, terminated by an obtuse stigma. The fruit is a large globose scarlet berry, with three cells, each cell containing one or two seeds, which are large, shining, nearly spherical, and enclosed in a sweetish pulp. Plate 8, fig. 4, (a) the flower situated on the disk of the leaf; $(b)$ the flower isolated; $(c)$ the seed.

This plant grows in heatly places and woods, abundantly in many parts of the south of England, rare in the north. The only localities mentioned for it in Scotland are Bothwell woods, and $\mathbf{S}$. Kelder woods near Ayr. Dillenius found it on heaths near Woolwich, and Ray tells us that it grew in herges near Black Notley in Essex. It is common in France, Italy, Spain, and Carniola. The flowers appear in March and April.

It was anciently called Bruscus, derived, it is said, from beus, box, and kelen, holly, in Celtic, signifying Box-holly*. Its provincial appellations are Knee-Holly and Prickly Pettigree.

Qualities and General Uses.-The tender shoots, just after they appear in spring, are sometimes gathered by the poor, and eaten like those of asparagus. "The branches were formerly used by butchers to sweep their blocks, and in Italy, and some other countries, they use them for manufacturing brooins and bee-hives. The branches, with the ripe fruit on them, were formerly stuck up in sand, with the stalks of Peony and Iris, displaying their capsules of ripe seeds; the three together made a winter nosegay for rooms. In landscape gardening, the plant is valuable as an evergreen, which will grow under

* Virgil distinctly refers to it when he says,

"Immò ego Sardois videar tihi amarior herbis,

Horridior rusco "Ecl. vii. I. 41.

and,

" necnon etiam aspera rusci

Vimina per sylvam." Geor. ii. I. 413 
the shade and drip of other trees. It harmonizes well with Daphne Laureola, Ulex Nana, and Vaccinium Vitis Idæa." *

The root is at first sweetish to the taste, afterwards bitter: it was formerly reckoned one of the five greater aperient roots. The berries contain a sweetish pulp. The seeds have been used as a substitute for coffee, but they are said to render the liquid diuretic $\psi$

Medical Properties and Uses. - The root of this plant has been long disused as a medicine, but it was once highly recommended as an aperient and diuretic in dropsies, urinary obstructions, and gravel. Dioscorides $\ddagger$ mentions it as possessing these properties, and Riverius $\S$ and Bauhin || relate desperate cases of dropsy which were cured by this remedy alone.

Etmuller strongly commends this plant as a valuable remedy in scrofulous tumours and ulcers; he recommends a drachm of the powdered root to be taken every morning. The same writer also experienced great advantage from the use of the berries formed into a conserve, in gonorrhœa and heat of urine, from whatever cause, taken in the quantity of two drachms to half an ounce.

To form the decoction, an ounce of the dried root was boiled in a pint and half of water down to a pint, of which a wineglass-full was taken three times a day, or more frequently, according to circumstances. For the infusion, half an ounce of the root, bruised, was added to a pint of boiling water, and drunk as tea. A distilled water has also been made from the leaves and berries.

* Loudon's Encyclopædia of Plants, p. 847.

† Launicheli de Rusco, ejusque medicamentosá praparatione. Venet. 1787 .

$\ddagger$ Lib. :v. c 146.

$\S$ Observ. Cent. 3, Obs. 52.

if Hist. Univ. Plant. tom. i. p. 582. 


\section{XXXVII. \\ CALAMINTHA OFFICINALIS.}

Common Calamint.

\section{Class XIV. Didynamia.-Order I. Gymnospermia.}

Nat. Ord. Labiate.

Gen. Char. Flowers axillary, generally in loose bracteated cymes. Calyx tubular, thirteen-nerved; throat mostly closed with hairs; upper lip three-toothed; lower lip bifid. Corolla with the upper lip nearly plain, emarginate; lower lip trifid, the middle lobe emarginate.

SPEc. Char. Whorls on forked, many-flowered stalks. Leaves with shallow serratures. Hairs in the throat of the calyx not prominent.

\section{S Y N ONYMES .}

Latin .... $\left\{\begin{array}{l}\text { Calamintha vulgaris. Bauh. Pin. 228. Ger. Em. 687. Raii } \\ \text { Syn. 243. } \\ \text { Calamintha flore magno vulgaris. J. Bauh, iii. 228. } \\ \text { Melissa Calamintha. Lin. Sp. Pl. 827. } \\ \text { Thymus Calamintha. Smith, Fl. Brit. 641. } \\ \text { Calamintha officinalis. Manch. }\end{array}\right.$

French.... Calament; Calament des montagnes.

Italian.... Calaminta.

Spanish.... Calaminto.

German.... Bergmïnze.

Dutch..... Berg calaminth.

Bavarian.. Plana mata; Poleg.

Russ. ..... Melissa.

Description.-The root is perennial, spreading, and fibrous. The stems are upright, bushy, obtusely quadrangular, and pubescent, attaining the height of about two feet. The leaves are ovate, somewhat cordate at the base, bordered with shallow 


\title{
XXXVIII.
}

\section{CARUM CARUI.}

\author{
Common Caraway.
}

Class V. Pentandria.-Order I. Digmia.

Nat. Ord. Umbeldifere.

Gen. Char. Calyx an obselete margin. Petals obcordate. Fruit compressed at the sides, oblong. Carpels with five, filiform, equal ridges, their inner faces plain. Channels with single vittæ. Seeds tereti-convex, plain in front.-Involucres various.

Spec. Char. Stem branched. Sheaths of the leaves ventricose. Partial involucre, none; general, scarcely any.

\section{S Y NON YMES.}

Greek .... xapos, Dioscorides; xaprov, Aretaus.

Latin ..... \{ $\begin{aligned} & \text { Carum pratense, Carvi Officinarum. Bauh. Pin. } 158 . \\ & \text { Carum, sive Careum. Ger. Em. 1034. Raii. Syn. 21 } \\ & \text { Carum Carui. Lin. Sp. Pl. 378. }\end{aligned}$

French.... Carvi ; Cumin des prés.

Italian.... Carvi ; Caro ; Cumino di prato.

Spanish... Alcaravea.

Portuguese Alcaravia.

German .. Mattenkümmel ; Gemeinerkümmel ; Felolkïmmel.

Dutoh .... Karwey; Veldkonyn.

Belgic .... Carwey; Caruwy ; Hof-Comyu.

Danish.... Kummen.

Polish .... Karney.

Russ..... Tmill.

Swedish .. Blædkummir. 

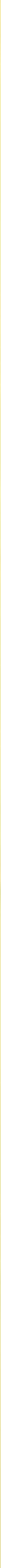

Description.-The root is biennial, fusiform, whitish, about the thickness of the thumb, and furnished with numerous fibres, The stems are erect, firm, cylindrical, striated, smooth, branched, and rise to the height of two feet. The leaves are long, sheathing at the base, doubly pinnate, and of a deep green colour; the radical ones are stalked, with numerous acute segments; those of the stem are opposite, very unequal, and divided into fine linear acute segments. The flowers are arranged in dense terminal umbels of about ten radii, with a general involucre of a few setaceous leaves, and no partial one. The calyx is a mere obsolete margin. The petals are five, nearly white, inversely heart-slıaped, and slightly emarginate at the end. The stamens are five, with capilliform spreading filaments, as long as the petals, tipped with globose two-lobed anthers. The germen is inferior, ovate, abrupt, surmounted by two short, afterwards elongated, filiform, spreading styles, tumid at the base, terminated by obtuse stigmas. The fruit is oblong, compressed at the side, and composed of two carpels, traversed by five filiform equal ridges, having interstices with single vittæ, and their inner faces plane. The seed is somewhat convex, narrow at both ends, plane in front. Plate 10, fig. $4,(a)$ half of a radical leaf; $(b)$ an entire floret of the natural size; $(c)$ the fruit, showing the two carpels separating at maturity.

This plant grows wild in France, Germany, Holland, Sweden, Poland, and as far north as Lapland. It occurs in meadows and pastures in several places in this country, and is also frequently cultivated. It flowers in June.

The ancient naturalists, and Greek and Roman plysicians, frequently mention this plant under the name of rapos, xapeor, careum, and it was so named, according to Pliny*, because it was peculiarly abundant in Caria, a province of Asia Minor.

Qualities and general Uses.-The Caraway, from being cultivated in our gardens, loses a great part of its natural acridity: the root becomes more voluminous and succulent; the frnit larger, more oily, and acquires a more aromatic, and agrec- 
able taste and odour*. The young roots are said to be more delicious than parsnips, and they are spoken of by Dioscorides, as a nutritious and agreeable food. It has been suggested, that these roots, ground, mixed with milk, and made into bread, formed the substance spoken of by Julius Cæsar, under the name of Chara, as eaten by the soldiers of Valerius $\uparrow$. The warlike Germans of old, made of the root a vinous drink, or preserved it in honey or must, and it is eaten occasionally in the present day, either raw, or boiled as a pot-herb; the leaves are also used for the last mentioned purpose. Bechstein asserts, that caraway, if carefully transplanted into richer soil, produces roots not inferior to those of the scorzonera, and likewise affords a very agreeable pickle. Goats, swine, and sheep are fond of the herbage of this plant, but cows and horses refuse it.

Many of the Tartars and Circassians prepare from the seeds a kind of farina, which they make into cakes, and which they consider a great dainty. The Swedish and German peasants flavour their cheese, soups, ragouts, and household bread with the seeds: they are also used in the distillation of spirituous liquors; and, incrusted with sugar, they form the well known comfits of the confectioners.

Caraway seeds give out the whole of their virtues by moderate digestion to rectified spirit; and the spirituous tincture is stronger in taste, but less powerful in smell than the watery infusion. Distillation elevates all the aroma of the seed, and along with the fluid, there generally rises a considerable quantity of essential oil, in the proportion of about one part in thirty, very hot and pungent to the taste. The leaves of the plant also afford an oil similar to that of the seeds, but in much smaller quantity.

Medical Properties and Uses.-The medical properties of these seeds are carminative, cordial, and stomachic. They

* Shakspeare adverts to it in the following passage:-." Nay, and you shall see mine orchard, where in an arbour we will eat a last year's pippin of my own grafting, with a dish of carraways, and so come forth ; come rousin, silence, and then to bed."-Henry IV.

† 'Tractatus botanico-criticus de chará Cæsaris. -J. G. Weinmann, Carolsruhe, 1769 . 
have been ranked amongst the greater warm seeds--viz. anise, fennel, caraway, cummin; and recommended in flatulencies, colic, dyspepsia, and other symptoms attending hysterical and hypochondriacal disorders.

In pharmacy they enter into many infusions and decoctions, particularly the infusion of senna, and any preparation of this kind, whether purgative, tonic, or stomachic, wherein warmth may be desirable, or griping of the bowels apprehended. Gèoffroy* recommends a scruple of the seeds in powder, with two drachms of sugar in a glass of good wine, in cases of flatılent colic. Etmuller commends them in similar disorders, and as efficacious in promoting the secretion of milk. Linnæus $\nmid$ considers them as a remedy not to be despised in tertian agues.

$\Lambda$ decoction of the root is sometimes given in clysters, combined with astringents, or purgatives, as the case may require.

The essential oil has been recommended in pains of the stomach, heart-burn, sickness, \&c., in the dose of from four to eight or ten drops on a lump of sugar, or in any kind of drink.

Both the seeds and the oil are employed externally in windy colics, and in some deep-seated pains, as ear-ache and toothache. A homely remedy is used by the country people of some districts in the first mentioned disease, which they find extremely efficacious. They pound a hot loaf, fresh from the oven, with a good handful or two of the seeds, and wetting the whole with brandy, or some other spirit, apply it to the part affected. An ounce of the seeds, infused in a pint of water, forms a carminative potion, which has been recommended for infants instead of the oil of caraway usually given by nurses.

The London Pharmacopœia directs a spirit to be thus inade from the seeds :

SIILIT OF CARAWAY,

Take of Caraway Seeds, bruised, a pound and a half;

- Mat. Med. iii. p. 266.

+ Flora Suecica, p. 95. 
Proof Spirit .......... a gallon.

Water enough to prevent empyreuma.

Macerate for twenty-four hours; then with a gentle fire distil a gallon. Dose, from two drachms to one ounce.

The distilled water, which is made in the usual manner, is given to the extent of an ounce or more. 


\section{XXXIX.}

\section{DAUCUS CAROTA.}

\section{Wild Carrot.}

\section{Class V. Pentandria.-Order II. Digynia.}

Nat. Ord. Umbellifere.

Gen. Char. Calyx five-toothed. Petals obcordate, with an inflexed point, unequal. Fruit compressed at the back; carpels with five primary ridges, filiform and bristly; the four secondary ridges equal, more prominent, with a single row of prickles which are slightly connected at the base; Channels under the secondary ridges with single vittæ. Seeds plane in front.-Involucres many-leaved.

Spec. Char. Bristles of the fruit slender. Leaves tripinnate; leaflets pinnatifid, with linear-lanceolate acute segments. Umbels with a solitary abortive, coloured flower in the centre.

SYNONYMES.

Greek..... jauros.

Latin ..... $\left\{\begin{array}{l}\text { Pastinaca tenuifolia sylvestris, \&c. Bauh. Pin. 151. Ger. } \\ \text { Em. 1028. } \\ \text { Daucus vulgaris. Raii Syn. } 218 . \\ \text { Caucalis Carota. Stokes' Bot. Mat. Med. ii. p. 64. } \\ \text { Daucus Carota. Lin. Sp. Pl.348. }\end{array}\right.$

French .... Carotte: Carotte sauvage.

Italian.... Carota; Dauco.

Spanish.... Zanahoria.

Portuguese. Cenoira.

German... Möhre; Mohrruibe; Vogehest; Gelbu Wurzel.

Dutch .... Wilde Peen; Vogelnest.

Polish..... Marchew.

Swedish.... Morot.

Sunscrit... Garjara. 
Description.-The root is perennial, fusiform, slender, firm, somewhat woody *, of a yellowish colour, penetrating deep into the soil, and furnished here and there with small rootlets. The stem is erect, cylindrical, branched, somewhat furrowed, hairy, and rises between two and three feet in height. The lower leaves are large, bipinnate; those of the stem gradually decrease in size, and become tripinnate, with linear-lanceolate acute segments; they are all petiolate, of a deep green colour, and clothed with short hairs, the footstalks nerved beneath. The umbels are large, terminal, composed of several radii; and form a plane surface at the top, when in flower, but as they approach maturity they contract and become concave; the flowers are small and generally white, except the solitary abortive one in the centre of the umbel, which is of a purplish colour. The general involucre is composed of many pinnatifid leaves; the partial one is more simple, undivided or three-cleft. The calyx consists of five small obscure teeth. The five petals are inversely heart-shaped, with the point inflexed; the outer often radiant, and deeply bifid. The filaments are spreading, filform, and longer than the corolla, with oblong anthers. The germen is inferior, ovate, imperfect in the outermost and central flowers; the styles are filiform, spreading, dilated at the base, and terminated by obtuse stigmas. The fruit is oblong, compressed at the back; each carpel is marked with five filiform bristly ridges, of which the the two lateral are on the inner face, and four secondary prominent ridges, with one row of prickles; the interstices are under the secondary ridges, with single vittæ. Plate 11, fig. 1, (a) floret somewhat magnified; (b) the ripe fruit magnified.

The wild Carrot, or Bird's-nest, as it is familiarly called, is amongst the most common of the umbelliferous plants, growing abundantly on the borders of fields and in pastures, in nearly all temperate climates. It is a biemnial, flowering in July, and ripening its seed in September.

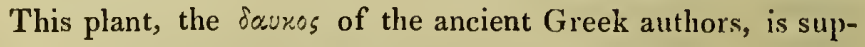
posed to have derived its name from $\delta a . \omega$, to make hot, on ac-

* This description, of course, is only partially applicable to the cultivated variety. 
count of its stimulant effects. It is spoken of by Pliny *, who states, that the most esteemed kinds were produced in Candia and Achaia. But the Cretan carrot, mentioned by Celsus as an ingredient in the famous Mithridate $\psi$, seems to have been the Athamanta Cretensis. The English word carrot, and the Latin carota, are derived, according to Theis, from the Celtic, car, red. 'The plant often goes by the name of bird's nest, in allusion to the umbels, which contract when the fruit begins to ripen, and form a dense concave body, the shape of which has suggested the above name in English, and the vogelnest of the Dutch and Germans.

The garden carrot is generally supposed to be a variety of the wild species improved by culture, and of this there can be little doubt, when the change effected in other esculent vegetables is considered; although Miller states, that those who have attempted to cultivate the wild sort are convinced of their being distinct; and others assert that the plant was introduced from Belgium in the reign of Elizabeth.

Culture. - The seeds do not retain their vegetative powers more than a year, for which reason the cautious cultivator should prove them before sowing. There are several varieties; the largest, called the Altringham, is chiefly used for field culture; and the orange-carrot, the early horn, and the late horn, are considered the best garden sorts. The main crop is sown in March or April, in a deep, warm, light, sandy soil, which should be dug two spades deep, for if the roots meet with any obstruction, they are apt to grow forked, and shoot out lateral roots; when manure is added, it should be buried deep, or thinly dispersed over the ground, to prevent the roots from being wormeaten. A calm day should be chosen for sowing, and the seeds should be well rubbed previously, and trodden in before raking. When the plants are come up, several successive hoeings should be given, and care should be taken to keep them at a proper

* Hist. Nat., lib. xxv. cap. 9.

f For the composition of this once-celebrated antidote against poison, dis. covered by the learned Mithridates, king of Pontus, which was said to have been so efficacious that he was unable to succeed even in poisoning himself, see an excellent edition of Celsus de Medicinâ, Latin and English, by Alexander Lee, A.M., M.D. 
distance from each other,-four or five inches if they are to be drawn when young, and from eight to ten, if they are intended to reach their full size. In order to preserve the roots for use, they should be dug up about the beginning of November, and laid in sand in a dry place, out of the reacl of fiost." Miller.

Parkinson informs us, that in his time carrot leaves were thought so ornamental, that ladies wore them instead of feathers. A pretty effect may be produced in winter, by selecting a large root, cutting it over about three inches from the top, and placing it in a shallow vessel of water in a warm room. The young and delicate leaves soon unfold themselves, and afford a very lively and elegant object.

M. Walford, a foreign agriculturist, states, that he is accustomed to sow carrots whenever he makes a plantation of pines, or other trees, when they begin to lose their leaves. On pulling up the carrots, he finds that the roots of the trees sustain little injury by twining around them; and the spaces that are left being soon filled with light mould, the tender roots of the young trees shoot with greater facility*.

Qualities and general Uses.-As a culinary article, the carrot is well known : it also affords a wholesome and nutritious food for cattle. A good wine may be made from the roots, and an ardent spirit. M. Brieger obtained from ten pounds of the root, one quart of what is called "first runnings," and half a pint of very strong spirit. It has been found that an acre of carrots produce considerably more sugar than five quarters of barley, the average product of an acre. A useful article of diet for voyagers is obtained from the root dried, and reduced to powder, and a tolerable kind of bread has been made from it. In the neighbourhood of Dusseldorf, and some other places, it is roasted and mixed with coffee, in various proportions. The seeds fermented in malt liquor give it an agreeable flavour, resembling that of lemon peel.

The root of the carrot contains more saccharine matter than barley, more likewise than the root of the parsnip, and is only inferior in this respect to the beet. According to Professor Brande, 1000 parts of carrots yield 95 parts of saccharine mat-

* Nouveau Dictionaire d'Histoire Naturelle, tom. iv. p. 369. 
ter, 98 parts of nutritive matter, and about 3 parts of starch; 1000 parts of parsnip yield ninety parts of sugar, while the same quantity of common turnips affords only thirty-four parts.

M. Braconnot discovered a substance which he designated pectic acid, and believed to be present in all vegetables, but he extracted it chiefly from the carrot. It has since been examined by Vauquelin*. In order to obtain pectic acid, the carrots are made into a pulp, the juice is expressed, and the solid part well washed with distilled water. It is then boiled for about ten minutes, with a very dilute solution of pure potash, or bicarbonate of potash, in the proportion of 5 parts to 100 of the washed pulp, and muriate of lime is added to the filtered liquor. The precipitate, consisting of pectic acid and lime, is well washed; and the lime removed by water, acidulated with muriatic acid. The liquid is then thrown upon a linen cloth, and the pectic acid is obtained, and may be washed with the greatest facility with pure water.

Pectic acid thus obtained is in the form of a jelly. It is insoluble in cold water and acids, and nearly so in boiling water. On the addition of a few drops of ammonia, it liquefies readily. It is remarkable for the extreme facility with which it gelatinizes large quantities of sugared water. One part of this acid dissolved in hot water, and added to 300 parts of sugared water, instantly forms a mass of trembling jelly; on this account it may be found useful in the preparation of various jellies. The soluble pectates are very valuable, as antidotes in cases of poisoning by several of the metallic salts.

The seeds of the wild carrot are thought to be superior to those of the cultivated kind, and are recommended for medicinal purposes. By distillation, or evaporation, water elevates the whole of their smell, and aromatic taste; if large quantities are distilled, a yellowish essential oil is obtained, having a pungent taste, and a powerful odour. Rectified spirit takes up all their virtues by digestion.

Medical Properties and Uses.-The expressed juice, or a decoction of this root, as well as the seeds, were considered by the older physicians as possessing specific qualities against

* Annales de Chimie et de Phys., xxviii. 173. 
gravel and stone " ; and as endowed with diuretic, deobstruent, and emmenagogue properties. Etmuller very strongly recommends it for these properties, and bears testimony to its efficacy against calculus in the bladder or kidneys. Rosenstein and Bosch consider it vermifuge, and recommend the juice, or a decoction of the root, as a gargle for the sore mouths of children, and for the thrush.

Marggraf directs the recent roots to be cut, well washed, and beaten into a pulp; the juice of which is to be expressed through a sieve, and inspissated to the consistence of honey, in which state it may be used at table instead of sugar, and is well adapted for infantile consumptive coughs and for worms.

The pulp of the root, when time has been allowed for the establishment of the vinous fermentation, forms an excellent cataplasm, which has been much lauded by Sulzer $\dagger$, Michaelis, and others, as an application to putrid and scrofulous ulcers, and to cancers, in which distressing affections they not only mitigate the pain, but abate the fotor. The Parisian Codex recommends the decoction of hemlock to be added to the poultice.

The dose of the bruised seeds is from a scruple to a drachm, or more. An infusion may be made with three spoonsful of the seed in a pint of boiling water + ; or infuse an ounce of the bruised seeds in a quart of good beer for twenty-four hours, which may be taken to the extent of two or three ounces, three times a day.

- A modern author, however, says, "We have seen the seeds of the wild carrot employed in calculous cases in considerable quantities, and for a length of time, but never found its efficacy very great." - Cullen's Mat. Med. ii. 562.

$\uparrow$ Journal de Medicine, tom. xxiv. p. 68.

‡ Woodville's Med. Bot., vol. iii. p. 445. 


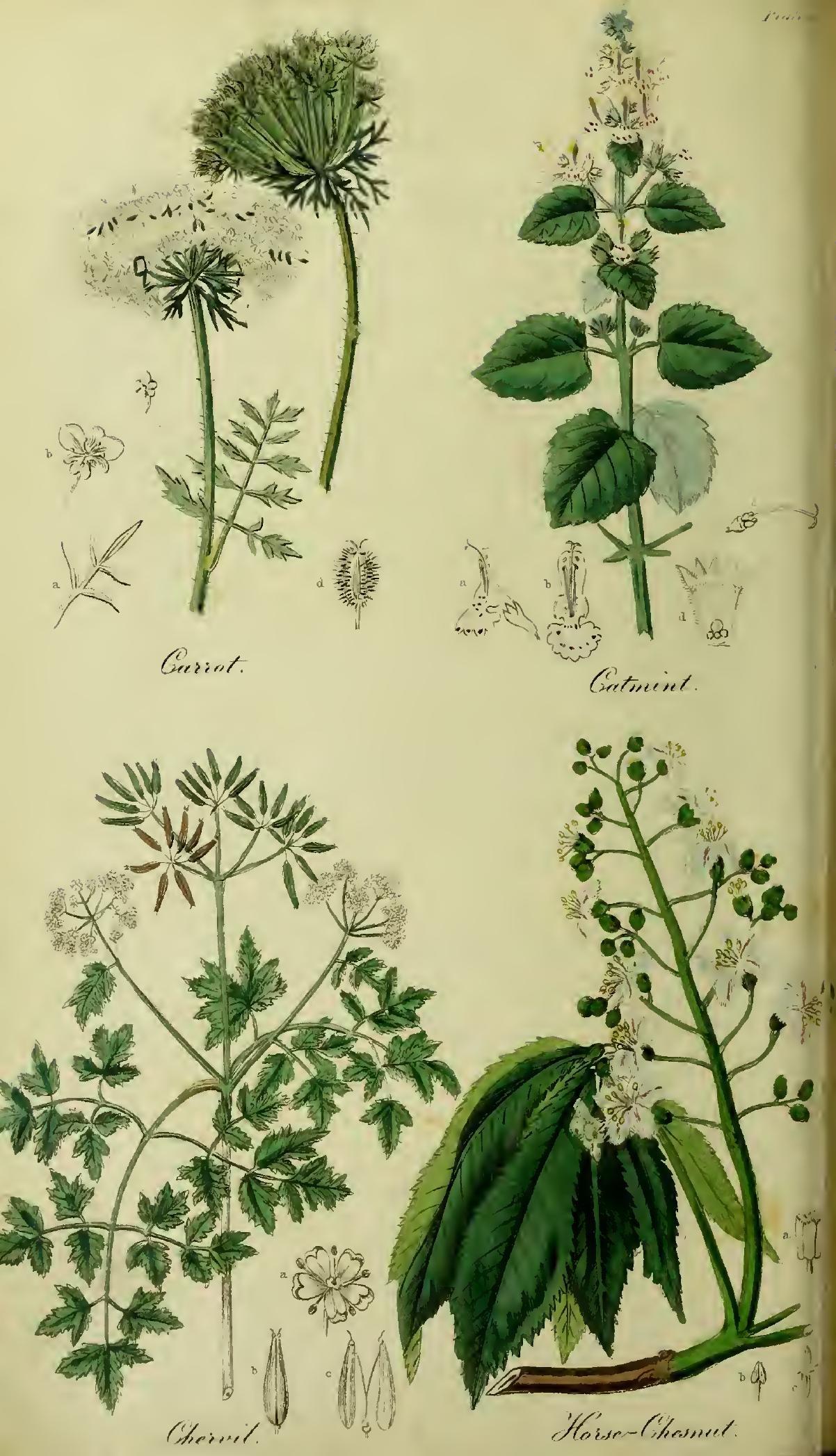
XL.

\section{NEPETA CATARIA.}

\section{Catmint.}

Class XIV. Dipynamia.-Order I. Grymosperma.

Nat. Ord. Labiate.

Gen. Char. Calyx tubular, many-ribbed, its mouth somewhat oblique, five-toothed. Corolla with the tube exserted; upper lip emarginate, lower lip trifid; the lateral lobes reflexed, the middle one broad, concave, notched.

Spec. Char. Flowers in spiked, somewhat stalked whorls. Leaves stalked, cordate, tooth-serrate.

\section{S Y NONY MES.}

Latin.... $\left\{\begin{array}{l}\text { Mentha Cataria vulgaris et major. Bunh. Pin. 220. } \\ \text { Mentha felina seu Cataria. Ger. Em. 682. } \\ \text { Nepeta major vulgaris. Raii Syn. 237. } \\ \text { Nepeta Cataria. Lin. Sp. Pl. 796. }\end{array}\right.$

French... Cataire; Chataire; Herb-au-chat.

Italian... Mattaria ; Erba gatta ; Nepitella.

Spanish ... Yerba gattera.

German.... Katzenkraut ; Katzenmünze.

Dutch..... Katte-kruid; Nipt.

Danish .... Katteurt.

Polish .... Mietka kotcza.

Swedish ... Kattmynta.

Description.-The root is perennial, long, woody, with numerous slender fibrils, of a blackish colour externally. The stems are numerous, branched, quadrangular, pubescent, and attain the height of two or three feet. The leaves are opposite, cordate, petiolate, green above, whitish beneath, with large acute serratures. The flowers are arranged in spiked, some- 
what pedunculate whorls. The calyx is monophyllous, tubular, many-ribbed, five-toothed. The corolla is large, white, or purplish, with deep rose-coloured spots; the tube long, cylindrical; the upper lip emarginate, the lower lip with three lobes, of which the central one is large, rounded, concave, and notched, and the lateral ones reflexed. The stamens are didynamous, approximating, shorter than the upper lip of the corolla, with reddish antliers. The germen is superior, fourlobed, supporting a filiform curved style, terminated by a bifid stigma. Plate 11, fig. 2, (a) entire flower magnified; (b) corolla, stamens, and style, viewed in front; $(c)$ the pistil ; $(d)$ the calyx, opened to shew the achenia.

This plant is found on hedge-banks and by road-sides, especially in a gravelly or chalky soil, in many parts of England. It is rare in Scotland, but has been discovered near Craig Nethan Castle, Glasgow, and between Culross and Kincardine : also at Rathfarnan and by the Shannon, opposite Limerick, Ireland.

The generic name has been derived either from Nepi, a town in Italy, or from Nepa, a scorpion, for whose bite the plant was a reputed antidote. It is called Catmint, because cats are extremely fond of it, especially when it is withered, when they will roll themselves on it, tear it in pieces, and chew it as long as a leaf remains. Ray mentions that he transplanted the common Catmint from the fields into lis garden; but the cats soon destroyed it: those plants however which came up from seed uniformly escaped, and thus he found the old proverb verified*.

It is eaten by sheep, but refused by cows, horses, goats, and swine.

Quafities.-The Catmint has a bitter taste and a strong smell, rather sweeter than that of mint and resembling pennyroyal. The active principle is extracted both by water and rectified spirit ; most completely by the latter. By distillation with water it yields a yellowish essential oil, which diffuses a strong and penetrating odour. Rectified spirit likewise elevates a portion of the odour and aromatic quality, but the greater part is left behind in the extract, which proves more grateful than the leaves in substance.

* "If you set it

The cats will eat it;

If you sow it

The cats will not know it." 
Medical Properties and Uses. - It might be expected that a plant which exercises so powerful an influence on the animal economy could not be destitute of medicinal properties; and several therapeutists assert that it has been consigned to unmerited oblivion. Herman, Bœcler*, and Gilibert $\dagger$, speak of its efficacy in chlorosis, hysteria, and amenorrhæa, and it is chiefly in uterine and dyspeptic disorders that its virtues have been celebrated. It has been administered in aqueous or vinous infusions, fomentations, injections, lavements, and baths. A drink formed by boiling the plant in hydromel has been recommended for allaying obstinate coughs. As a remedy in jaundice + , the expressed juice has been given in the dose of two ounces at a time, but the extract made into pills with a small proportion of aloes is a more eligible form.

* Cynosura Mat. Med. tom. i. p. 470.

+ Demonstrations Elem. de Botan. tom. ii. p. 79.

+ Flore Medicale, tom. ii. p. 184. 


\section{XLI.}

\section{CHELIDONIUM MAJUS.}

\section{Common Celandine.}

\section{Class XIII. Polyandria.-Order I. Monogynia.}

Nat. Ord. Papaveracere.

Gen. Char. Calyx of two caducous leaves. Petals four. Stigma two-lobed. Pod superior, linear, with one cell and two valves.

Spec. Char. Peduncles umbelled. Leaves pinnatifid, with roundish, lobed and toothed segments.

S Y N O Y Y E S.

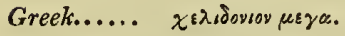

Chelidonjum majus vulgare. Bauh. Pin. I44.

Chelidonium majus, folio majus dissecto. Ger. Em. 1069.

Latin.... \{ Papaver corniculatum luteum; Chelidonia dictum. Raii Syn. 309.

Chelidonium majus. Lin. Sp. Pl. 723.

French.... Chelidoine ; Grande Chelidoine; Eclaire ; Felougne.

Italian .... Celidonia; Cenerognola.

Spanish ... Celidonia ; Celidonia mayor.

Portuguese. Celidonia.

German ... Schellkraut ; Schoelkraut; Schwalbenkraut.

Dutch ..... Schell-kruid ; Gouw.

Danish.... Selidon.

Swedish.... Sval-ort.

Bohemian.. Celidonya.

Polish.... Jaszkolke.

Description.-The root is perennial, cylindrical, tapering, fibrous, and of a reddish-brown colour. The stems are upright, branched, slightly hairy, brittle, and rise from one to two feet $\mathrm{in}$ height. The leaves are alternate, large, pinnated, with from 
three to five decurrent leaflets, which are broadly ovate, lobed, and crenated, the terminal one largest, and generally threelobed, of a bright green colour above, glaucous beneath;-their footstalks hairy. The flowers stand on long, hairy pedicels, and are disposed in umbels on the summit of the axillary stalks. The calyx is inferior, consisting of two ovate, concave, entire, caducous sepals *. The corolla is composed of four roundish, obtuse, spreading petals, placed in a cruciform manner, and of a bright-yellow colour. 'The stamens are numerous, shorter than the corolla, with yellow compressed filaments, and oblong, erect, two-lobed anthers. The germen is cylindrical, somewhat curved, terminated by a small, sessile, obtuse, bifid stigma. The fruit is a long, linear pod, rather turgid, of one cell and two valves, containing numerous globose, dark, shining seeds, arranged in two rows along a linear receptacle at each side of the pod. Plate 12, fig. 1, (a) the calyx, stamens, and pistil ; (b) the pistil; $(c)$ the fruit or silique as it opens at maturity ; $(d)$ the crested seed.

There is a variety (by some considered a species, Chelidonium laciniatum) which has jagged leaves and petals, and is occasionally found wild in Britain.

The common Celandine occurs in waste places, on rubbish and old walls, especially near towns and villages. It is met with nearly all over Europe, from Greece to Siberia, and in many parts of North America. It flowers in May and June.

The generic name is derived from $\chi \equiv 7.6 \delta \omega \nu$, a swallow, either because it flowers about the time of the arrival of those birds, or from an ancient tradition, that they used it to open the eyes of their young, or to restore their sight $\uparrow$. 'The English word Celandine, is evidently a corruption of Chelidonium.

Qualities and general Uses. - The whole plant in its recent state, if slightly wounded, exudes an orange-coloured juice of a disagreeable odour, which has been compared to that of stale eggs. It lias a bitter taste, accompanied with an acridity, which is diminished by the process of drying, while the bitterness is augmented. These properties reside in the greatest degree in the root. Botll rectified spirit and water extract its virtues; the juice of the stem and leaves gives to the former a

* In æstivation the calyx is of one piece, but subsequently it separates into two leatlets by the expansion of the corolla.

+ 'The swallows use celandine, the linnet euphrasia.-More. 
green colour, and that of the root a brownish-yellow. The pungency of the Celandine is not of a volatile nature, since it does not rise in distillation with water, but it is almost dissipated by drying the plant.

The bright colour of the juice has suggested some experiments with it in dyeing, but no permanent colour could be obtained. Rössig, however, a German writer, asserts that by fermentation a good blue colour was procured, similar to that of the Isatis tinctoria or Woad.

No animal has been known to eat this plant.

Poisonous Properties.-The juice of this plant is an acrid poison, and is capable of producing very deleterious effects, if improperly used. Orfila found that, introduced into the stomach of animals, it produced vomiting, loss of sight and hearing, incapacity to stand, and death : the stomach was found inflamed, and the lungs livid and distended with blood. When applied to wounds it produced the same effects, except that there was no vomiting, and the stomach was not inflamed.

As there is no antidote to this poison, the usual evacuants and antiphlogistic treatment must be resorted to, as recommended under Aconite* and Bryony $t$.

Medical Properties and Uses.-Linnæus, Murray, Gilibert and others, express their astonishment at the oblivion into which a plant so energetic as the Celandine has fallen, while the ancients knew how to appreciate its qualities. Dioscorides and Galen employed it, infused in white wine, for the cure of jaundice; the former, with the addition of anise. Forestus + gave it infused in beer, and Chomel recommends the leaves to be macerated in whey, to which a little cream of tartar is added. "I think it would be better to adopt the method pursued by Professor Wendt: he expresses, in summer, the juice of the plant, and mixes it with an equal quantity of honey. The dose, which at first is two drachms, is gradually increased to half an ounce, diluted with one or two spoonsful of water. In spring and autumn he employs the juice of the root, and in winter he administers the extract only, of which he forms two-grain pills : he commences by giving two, increasing the dose as far as ten, and continuing this quantity until the cure is effected. But the Erlangen professor, carried away by his predilcction for Celan-

"See p. $3 . \quad+$ See p. $100 . \quad$ Obs. et Curat. lib. xix. obs. 40. 
dine, attributes to it virtues too potent and too multifarious; he not only prescribes it in jaundice, visceral obstructions, intermittent fevers, and dropsies, but recommends it as extremely efficacious in scrofulous and syphilitic affections." * Dr. Schallern $\uparrow$ has employed Celandine internally and externally to cure diseases of the eyes; he flatters himself that he has by this means prevented cataract, dissipated ophthalmia, removed specks, and cured amaurosis. Kramer + recommends it to be used as tea in gouty and calculous affections.

Tragus greatly extols its virtues in contagious and malignant diseases: he asserts that a decoction of the root in vinegar, with the addition of theriaca, has been known to cure those attacked by the plague if they kept themselves in bed, and took care not to check the perspiration. It was esteemed a specific in the epidemic called the "sweating sickness" in this country.

Half a drachm to a drachm of the dried root in powder is directed for a dose; or an ounce of the fresh root infused in a pint and a half of white wine, of which a wine-glassful is to be taken at a time.

It has also been used as a topical application in some obstinate cutaneous diseases. Geoffroy mentions, that the expressed juice cleanses and heals wounds and ulcers $\S . \quad \Lambda$ poultice formed of the bruised leaves and stalks has been found useful in herpes, and has been extolled for curing the itch. Ettmuller || particularly recommends the external application of this plant to those odematous swellings of the feet which succeed to violent fevers and other severe diseases.

The use of the plant externally is well known to country people as efficacious in removing warts. The method of applying it is simply to break the stalk, and touch the parts affected with the yellow juice which exudes.

The great celebrity which the Celandine once enjoyed as a remedy for jaundice, probably originated in the doctrine of signatures.

* Flore Med. tom. ii. p. 218.

† " Dissertatio inaug. quâ Chelidonii virtus tirmatur."-Erlanga, 1790.

† In Act. Berol. vol. viii. p. 45.

$\$$ He likewise advises its application to specks and films of the cornea, and even to sound eyes that are weak, but no persons with common sense: would thus tamper with so delicate an organ.

II Materia Med. vol. iii. p, 312. 


\section{XLII.}

\section{ERY'IIIRAA CENTAURIUM.}

\section{Common Centaury.}

\section{Clees: V. Pentandhia.-Order I. . Monogynia.}

Nat. Ord. Gentianee.

Gen. Char. Calyx fire-cleft. Corolla funnel-shaped, inarcescent, with a short limb. Anthers after bursting, spiral. Stigmas two. Capsule linear, two-celled.

Spec. Char. Stem nearly simple. Leaves ovate-oblong. Flowers in dichotomous panicles. Calyx half as long as the tube of the corolla.

SY NON Y MES.

- Centaurium minus. Bauh. Pin. 278. Raii Syn. 286.

Centaurium parvum. Ger. Em. 547.

Latin ..... Gentiana Centaurium. Kin. Sp. Pl.332.

Clironia Centaurium. Curt. Lond. fusc. 4. t.22. Fl. Brilt. 257.

Erythræa Centaurium. Ronealm.

Fronch.... Petit Centaurée.

Italian.... Centaurea minore.

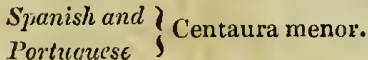

German.... Tausengildenkraut.

Dutch..... Deusendguldenskruid; Kleine Santory.

Danish ... Tusindgilden.

Polish .... Centurzye mıieysza.

Swedish ... Tusengyllen.

Description. - The root is annual, woody, branching, fibrous, and of a yellowish colour. 'The stem is erect, slender, angular, leafy and smooth, sometimes branched, rising from eight to twelve inches in height. The root leaves are tufted, spreading, 

threc-nerved, broader than those of the stem, which are in distant pairs, obovate, sessile, smooth, and of a bright green colour. The flowers are arranged in a fasciculate, corymb-like panicle, at the top of the stem. The calyx is about half the length of the tube of the corolla, smooth, striated, and five-cleft. The corolla is rose-coloured, funnel-shaped, withering, closing at night and at the approach of rain; the limb short, and divided into five ovate segments. The stamens are five, shorter than the tube, with thread-shaped filaments, and oblong yellow anthers, which become spiral after the pollen is discharged. The germen is oblong, compressed, surmounted by a straight cylindrical style, terminated by a roundish bifid stigma. Plate 12, fig. $2,(a)$ the corolla opened to show the stamens; $(b)$ the pistil ; (c) anther.

This elegant plant is frequent in heaths and dry gravelly pastures in this country, and occurs in similar situations in most parts of Europe. It flowers in July and August.

The generic name is derived from epulpos, red, in allusion to the colour of the flowers. The term Centaurium has becn applied to this species because its virtues were supposed to have becn discovered by the centaur Chiron, one of the earliest cultivators of botany and medicine. It has been called Lesser Centaury, in contradistinction to the Centaurea Centaurium, or Great Centaury.

There are two or three other species of Erythræa met with on our sea-shores, principally distinguished by their dwarfislı stature and the greater length of the calycine tube; hence they are considered mere varieties by some botanists. The genus consists of about thirty species, all pretty, hcrbaceous, and annual plants, but impatient of cultivation.

Qualities.--The common Centaury is nearly inodorous, but evcry part of it is impregnated with an intense bitterness. Both water and alcohol extract the whole of its active principle, leaving the insoluble part perfcctly insipid. It appears to contain a bitter resin and mucus. The aqucous decoction yields, by evaporation, a bitter extract.

Medical Properties and Use.-This plant has been held in repute from the days of Galen to the present time, and is still acknowledged by the medical collcges of Great Britain. The tops are the parts chiefly recommended, and these should be gathered while in full flower. It is mosirlond tonic and uno; 
septic, and especially on account of the former quality, not a bad substitute for some of the more expensive remedies now in use. As a stomachic in dyspeptic complaints, it proves very beneficial by increasing and strengthening the powers of the stomach and digestive organs; and removing obstructions of the liver and mesenteric glands. In these respects it is not inferior to the yellow gentian, while in intermittents and other febrile disorders it has well supplied the place of Peruvian bark. Dioscorides and Galen, who extol the virtues of the plant, remark that it sometimes proves cathartic; but it is probable that this effect is only produced in peculiar cases, or by a very large dose. Its efficacy in the gout has also been greatly praised, and it was a principal ingredient in the celebrated Portland powder*. It has not been less commended as an external application to old ulcers and scald-head. Wedel $\uparrow$ relates that a sinuous and fistulous ulcer, esteemed incurable, was healed by the application of a cataplasm formed of this herb. Others recommend a lotion formed with a strong decoction of it. Simon Paulli and Palma'rius seem to have had great faith in the Centaury as a cure for liydrophobia. Common Centaury may be given either in powder, infusion, tincture, or extract. The dose of the powder is from a scruple to a drachm; if given with the view of curing fevers, the latter quantity will be required.

SIMPLE INFUSION OF COMMON CENTAURY.

Take of tops of common Centaury, dried, six drachms ;

Boiling water, ............ half a pint.

After sufficient boiling, strain. An ounce and a half to two ounces may be given three or four times a day.

COMPOUND INFUSION OF COMMON CENTAURY.

Tops of common Centaury, dried, one ounce;

Avens root, 7 of each ........two drachms;

Boiling water, ............... one quart.

Pound the ingredients in a mortar, then pour on the hot water, and when cold, strain off the liquor; then add

Compound tincture of cardamoms, two ounces.

* The following was the composition:-Equal quantities by weight of the roots of birthwort and of gentian, the tops and leaves of germander (Teucrium Chamadrys) ground pine, (Ajuga Chamapitys), and lesser Centaury, powdered and inixed together.

+ Diss. de Cent. min. p. 29. 
A wine-glassful of this infusion may be taken two or three times a day, according to circumstances.

It has been found very serviceable in cases of obstructed menstruation, an aloetic purge being administered occasionally.

$$
\text { TINCTURE OF COMMON CENTAURY. }
$$

Take of tops of common Centaury, dried, two ounces;

Rectified spirit, ............ one pint.

After sufficient extraction, strain off the liquor, and pour it on

Tops of common Centaury,..... two ounces.

Then digest, express, and filter.

This tincture is reputed stomachic and anthelmintic, and is also used in intermittent fevers. A drachm or more may be given at a time.

An extract may be prepared in the usual manner, five grains of which, with an equal quantity of extracts of wormwood and gentian, and four drops of oil of caraway, may be made into pills of three grains each. These may be taken at one dose, and repeated if necessary. 


\section{XLIII.}

\section{AN'THEMIS NOBILIS.}

\section{Common Chamomile.}

Class XIX. Syngenesia.-Order II. Polygamia SUPERFLUA.

Nat. Ord. Composite.

Gen. Char. Involucre hemispherical, imbricated with nearly equal scales, membranous at the margin. Receptacle convex, chaffy. Fruit crowned with a membranous border or pappus.

Spec. Char. Leaves bipinnate, their segments linearsubulate, a little downy. Scales of the receptacle membranous, scarcely longer than the disk.

\section{S Y NON Y MES.}

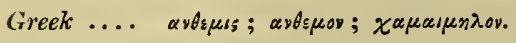

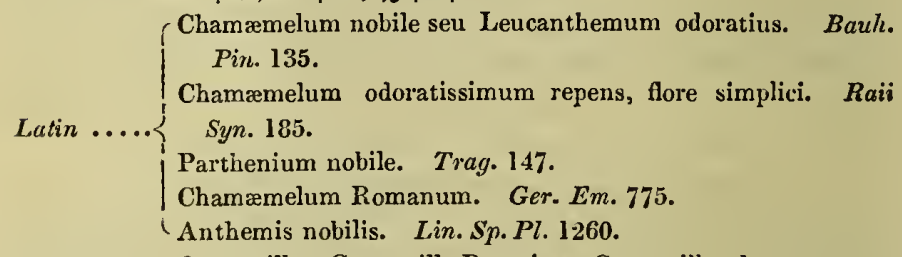

French... Camomille; Camomille Romaine; Camomille odorante.

Italian... Camomilla Romaine; Camomilla odorata.

Spanish ... Manzanilla.

Portuguese Marcella Romana.

German .. Kamille; Römisch Kamille.

Dutch .... Camille; Roomsche Camille.

Danish .. Romerske Cameelblomster.

Swedish .. Romerske Kamillenblommel.

Polish .... Rumianek.

Tamool .. Schamaindu pu.

Arabic.... Ehdaklmerza.

Description.- The root is perennial, fibrous, and spreading. The stems are procumbent, from six to twelve inches in length, herbaceous, hairy, much branched and leafy, and of a pale green colour. The leaves are alternate, sessile, bipinnate, the 
pinnæe linear, somewhat lairy, pale green, and generally divided into three acute segments. The flowers stand singly on long striated, hairy peduncles terminating the branches; the disk is yellow, at length conical, and the ray white. The involucre is hemispherical, and composed of several small imbricated nearly equal scales, with membranous margins. The florets of the disk are numerous, hermaphrodite, tubular, and five-toothed; those of the ray or circumference, generally about eighteen in number, are long, spreading, ligulate, and three-tootlied at the extremity, the tube enclosing a pistil only; the receptacle convex, honey-combed, and beset with chaffy scales. The five filaments are capillary, very short, and have their anthers united into a cylindrical tube. The germen is obovate, terminated by a filiform style, and a bifid spreading stigma. The fruit is obovate, crowned with a membranous border or pappus. The seed is solitary and erect. Plate 14, fig. $1,(a)$ involucre cut through, showing the receptacle, on the summit of which is left a floret accompanied by its scale; (b) floret of the disk; (c) floret of the ray.

This useful plant is widely dispersed over the globe, both in warm and temperate climates. It flourishes in dry gravelly pastures and waste places in various parts of England, and in the isles of Cumrae and Bute, Scotland, flowering from the end of July to September.

The generic name is derived from $\alpha v \theta ; s$, a flower, on account of the profusion of its blossoms. The common English name of the plant is a corruption of Chamæmelum, formed from $\chi \alpha u \alpha$, on the ground, and $u r, \lambda s v$, an apple, because the plant smells like apples, or rather quinces*. The Spaniards call it manzanilla, or little apple. A double variety of this plant is often cultivated in gardens and sold instead of the single, but is much less efficacious as a medicine. The principal virtues of chamomile are supposed to reside in the involucre, and the unnatural development occasioned by the production of double flowers seems to divest it in great measure of the qualities for which it is so much valued + .

- Plin. Hist. Nat. lib. xxii. c. 21.

+ Much of what is brought to the London market is grown about Mitcham, in Surrey. The soil best adapted for it is a dry sandy loam. The flowers are collected before they are fully blown, and carefully dried. 
There are several other species of Chamomile, but the only one of any consequence is the Anthemis Cotula, stinking chamomile or May-weed, which is distinguished by its very smooth bipinnatifid leaves with awl-shaped segments, its conical receptacle with bristly scales, and fruit without any margin or pappus. It grows in corn-fields, has a fetid smell, and is said to blister the hands of those who gather it. It is still used by the peasantry in the United States as a sudorific in chronic rheumatism, and was formerly recommended by Tragus and others in the form of decoction, as a remedy in hysteria and worm cases, and externally in fomentations. The wild Chamomile (Matricaria Chamomilla) is generically distinguished by its receptacle being destitute of scales and nearly cylindrical; the rays of the florets are very obtuse and notched at the extremity, and the scales of the involucre obtuse. It grows in corn-fields and waste places, flowering in August.-This has a bitter taste and faint aromatic smell, and possesses the virtues of the true Chamomile in an inferior degree.

Qualities.-The whole plant is odorous, but the flowers exhale a peculiar aromatic smell, which is very powerful and not unpleasant. They are bitter and aromatic to the taste, with some degree of warnith. Both water and alcohol take up the whole of their active qualities. By distillation with water they yield a small quantity of essential oil of a blueish colour. By inspissating a decoction of the plant its peculiar flavour is dissipated, but the bitterness remains. Rectified spirit extracts more of the flavour than water. The flowers yield by analysis a gumresinous principle, tannin, camphor, and an essential oil; by treating them in the same manner as black pepper, Dr. Thomson has obtained a considerable quantity of piperine to which he ascribes the active antiperiodic properties of the flowers.

Medicaz Properties and Use.-Chamomile' flowers are tonic, antispasmodic, and slightly anodyne. When given in substance, in doses of half a drachm to a drachm every three or four hours, in the absence of the paroxysms, they have been found very serviceable for the cure of intermittent fevers; but in these cases it is necessary at the same time to give opium and astringents, if the bowels be easily affected. Bodard* very

* Proprićtés médicinales de la Camomille nolble, 8ro. 
earnestly recommends Chamomile in fevers, and Morton *, Hoffman $\uparrow$, and Heister + , found it more effectual than the Peruvian bark. Dr. Cullen $\S$ also observed that his countryman, Dr. Pitcairn, was of opinion that the powers of Chamomile were in this respect equal to the bark.

Chamomile, especially when combined with ginger or other aromaties, and the alkalies, is an excellent stomachic in indigestion, flatulent colic, gout, ehlorosis, periodical headaches, bilious affections of the stomach attended with morning sickness, flatulent eolie, and in chronic debility of the intestinal eanal. In diarrhœas it should not be used. A strong infusion of Chamomile is a very common and efficient emetic, and one which may be given in the most delieate habits, as it does not leave the stomach in a debilitated state, but, on the contrary, invigorates that organ.

Ettmuller commends it greatly for the relief of those pains in the region of the kidneys arising from gravel and calculus, and the after-pains following severe labours. Indeed its anodyne properties, though little known, are very considerable; and it has in many eases procured relief from pain, where no propensity to sleep, or any other narcotic consequences were pereeived. This effeet was so striking to Ettmuller in the eases of severe after-pains, that he deseribes it as almost miraculous. He administered a decoction of the flowers in beer, and aftirms, that to his knowledge, this decoction had procured almost immediate relief, when opium and other anodynes had failed $\|$.

Both Forestus and Ettmuller था speak of the anodyne influence of Chamomile over eardialgia, or severe burning pain at the stomach, either exhibited in infusion or in the form of a tincture.

* Exercit. I. de febr. interm. cap. 6. Morton's celebrated powder was composed of one scruple of chamomile flowers, ten grains of salt of wormwood, and ten grains of calx of antimony.-Thompson's Lond. Disp. 7th Edit. p. 177.

+ Diss. de præstan. rem. dom. p. 29.

$\ddagger$ Diss. de Med. Germ. indig. p. 13.

§ Woodville, Med. Bot. vol. ii. p. 285.

II "The infusion of an ounce of Chamomile flowers in a pint of good beer, which has just been made to boil, will be found sufficiently strong for most ptirposes. The whole of the liquor will require to be squeezed out from the flowers. From a wine-glass to a tea-cupful is a dose; and this, in cases of great pain, may be repeated every hour or two, till ease is procured." Waller's Brit. Dom. IIerb. p. 80.

9) Geoffroy, Tract. de MIed. tom. iii. p. 301. 
We shall now speak of the external application of Chamomile, which is still very general, particularly as a fomentation.

It has been a prevailing opinion among medical practitioners of late years, that the only good resulting from fomentations was owing entirely to the heat which they conveyed to the part, and practising on this theory, it has been usual to employ hot water only. Physiological experiments, however, have shewn that vegetable substances, as well as others, are absorbed from the surface, and being received in this manner into the system, produce precisely the same effect; hence, the fomentations made by a strong decoction of Chamomile, poppy-heads, and other similar plants, will be found much inore effectual in relieving pain than the simple application of hot water.

Fomentations of Chamomile are used in colic, local and intestinal inflammations, and to phagedenic ulcers * ; and the infusion is also found to be a useful addition to emollient anodyne glysters, in flatulent colic, and in irritations of the rectum producing tenesmus.

In the form of a cataplasin, Bodard recommends it to painful tumours of the breast. It has also been found of great service as a bath for the feet and legs, both in very painful and dangerous colics, and in some violent headaches. In all kinds of contusions, and in the tumefactions whicl succeed to difficult and protracted births, small bags filled with the flowers boiled in wine or water, are strongly recommended to be applied hot.

Besides, the infusion and decoction of the flowers of Chamomile, there is also prepared an extract and oil.

The dose of the powdered flowers is from half a drachm to two draclims, twice or thrice a day.

$$
\begin{gathered}
\text { INFUSION of cHAMOMILE } \uparrow \text {. } \\
\text { Take of Chamomile flowers, two drachms ; } \\
\text { Boiling water .... half a pint. }
\end{gathered}
$$

Macerate for ten minutes in a lightly covered vessel, and strain.

A good stomachic and tonic, which may be given in doses of from one to two ounces, two or three times a day. When exhibited warm it excites nausea, and is occasionally employed to assist the operation of emetics.

* Bodard extols them as antiseptic.

+ Infusum Anthemidis. Pharm. Lond. 


\section{DECOCTION OF CHAMOMILE *}

Take of Chamomile flowers, dried, one ounce;

Caraway seeds, bruised.. half an ounce;

Water............ five pints.

Boil for a quarter of an hour, and strain.

Used for the purpose of fomentations and glysters.

$$
\text { EXTRACT OF CHAMOMILE } \uparrow \text {. }
$$

Take of Chamomile flowers, dried, one pound ;

Water ............. one gallon.

Boil down to four pints, and strain the liquor while it is hot; then evaporate it to a proper consistence.

It has scarcely any efficacy when used alone; but it is an useful adjunct to rhubarb and sulphate of zinc, as a stomachic pill. Ten to twenty grains may be given for a dose, twice or thrice a day.

$$
\text { OIL OF CHAMONILE } \ddagger \text {. }
$$

Eighty-two pounds of the flowers yield eighteen drachms of oil.

It is occasionally used in cramp of the stomach, but more commonly as an addition to purgative pills. The dose is from five to ten drops.

- Decoctum Anthemidis Nobilis. Pharm. Edinb.

† Extractum Anthemidis. Pharm. Lond.

* Oleum Anthemidis. Pllarm. Lond. 
XLIV.

\section{AESCULUS HIPPOCASTANUM.}

\section{Horse-Chestnut.}

\section{Class VII. Heptandria.-Order I. Monogynia.}

\section{Nat. Ord. Hippocastanee.}

Gen. Char. Calyx monophyllous, five-toothed, inflated. Petals four or five, unequal, pubescent, inserted into the calyx. Capsule three-celled, echinate.

Spec. Char. Leaves digitate, of seven obovate, acuminate leaflets. Petals five, spreading.

S Y N O N Y E S.

Latin .... $\left\{\begin{array}{l}\text { Castanea folio multifido. Bauh. Pin. } 419 . \\ \text { Castanea Equina. Ger. Em. 1442. Raii Hist. } 1683 . \\ \text { Hippocastanum. Clus. Hist. p. 7. } \\ \text { Fsculus Hippocastanum. Lin. Sp. Pl. } 488 .\end{array}\right.$

French.... Marronier d'Inde.

Italian... . Castagno d'India ; Marcone.

Spanish ... Castano de caballo.

Portuguese.. Ippocastano.

German ... Wilde Kastanie; Rosskastanie.

Dutch .... Paardenkastanie.

Danish .... Hestekastanier.

Polish .... Kasztan owdzikich.

Swedish ... Hœstkastanie.

Description.-The common horse-chestnut is a stately tree, rising to the height of forty or fifty feet; sending off numerous spreading branches, covered with a rough brown bark. The wood is rapidly formed, and is white and soft, but soon decays. The leaves are digitate, composed of seven large, obovate, acuminate, serrate leaflets, of a light-green colour, and proceed 
from the extremity of a common petiole. The flowers are arranged in terminal, somewhat panicled, racemes, on rather short peduncles. The calyx is tubular, monophyllous, and divided at the margin into five obtuse teeth. The corolla consists of five unequal spreading petals, which are ovate, somewhat undulated at the margin, white, and inserted by narrow claws into the calyx, with a rose-coloured or yellowish mark at the base. The stamens are seven in number, with awl-shaped, curved, tapering filaments, about the length of the petals, and oblong, somewhat incumbent anthers. The germen is roundish, three-cornered, and three-celled; the style simple, short, filiform, acute, terminated by a pointed stigma. The fruit is a coriaceous, three-celled, three-valved capsule, beset externally with short spines, and containing in general two seeds, which are large, roundish, shining, and destitute of albumen; the embryo is curved, inverted, with - thick, very fleshy, cohering cotyledons; the plumule is very large, two-leaved; the radicle, conical, curved, and turned towards the hilum. Plate 11, fig. 4, (a) the calyx; (b) a single stamen; (c) the pistil.

This well known tree migrated originally from the north of Asia, by Constantinople, about the middle of the sixteenth century : it is not known in what year, but Matthiolus * is the first botanist who mentions it. In the time of Clusius, it was so rare that when he left Vienna, to which city much of the fruit was brought from Constantinople in 1588, he only saw one tree, which was not more than twelve years old. 'That it was very little known here in 1630-40 may be gathered from Parkinson, who states, that he cultivated it in his orchard as a fruit tree, esteeming the nuts superior to the ordinary sort. It is . now very common in this country, especially in parks and avenues, and affords a magnificent spectacle during the month of May, when its flowers are in full perfection.

The generic name is derived from esca, food, whence asculıs, a term which the Romans gave to the tree now called Quercus Essculus. Hippocastanum is compounded of $ı \pi \pi \circ \varsigma, a$ horse, and $x \alpha \sigma \tau \alpha \nu \circ y, a$ chestnut, because horses are said to eat the fruit greedily, and by it to have been cured of coughs and pulmonary disorders.

- Epist. medicinalibus (Oper. om. p. 101. 125). 
Qualities and general Uses. - The timber of the horsechestnut is white and soft, but not durable; it is consequently very little used in building. The various parts of the frnit have been applied to several useful purposes : the nuts furnish a grateful food to horses, deer, and poultry, and have been recommended for fattening cattle; the milk of cows that feed on . them is said to be very rich. Before giving them to sheep, it has been thought advisable to macerate them in caustic alkali, or lime water, in order to take off the bitterness, afterwards to wash them in water, and then boil them to a paste. If they were allowed to germinate, and then divested of their bitter and acrimonious qualities, they might probably afford a kind of bread; spirit might likewise be obtained from them by distillation. They yield a large quantity of starch, and when boiled and steeped in water, a saponaceous substance is procured, which may be substituted for common soap, and used in bleaching flax, hemp, and wool. A cosmetic powder may be also obtained from them, equal to that prepared from bitter almonds.

Sprogel, an ingenious German, has prepared a kind of paste or size from the fruit, which is preferable to that made of wheaten-flour. The nuts are first cleared of the hard shell, as well as the inner skin; then cut into three or four parts, dried hard in an oven, and afterwards reduced to fine flour; rain water, with a little alum dissolved in it, is then poured upon them, and the whole is worked into a proper consistence. No moths or vermin will breed in the articles cemented with this substance. Leonhardi observes, that the prickly husks may be advantageously employed in tanning leather, and when burnt to coal, they are said to produce an excellent black water-colour. The brown, glossy integument of the fruit, bruised and boiled in water with the addition of a little potash, makes a dark brown dye, which imparts to cloth previously dipped in a solution of green vitriol, a yellow brown, and to that prepared in alum water, a faint red-brown colour. The leaves and bark of the tree also communicate a brown dye.

The bark, which is the part used in medicine, has a slight aromatic odour, and an astringent, somewhat bitter taste. Its virtues are extracted both by water and alcohol. The sulphates of iron and zinc throw down from the infusion a dark-coloured precipitate. The yellow colour of the infusion made either 
with alcohol or water, changes to a dull blue if diluted with water*. According to the partial arialysis of M. Henry $\downarrow$, the bark contains scarcely any resin. Its soluble contents, which are chiefly extractive and mucilage, are dissolved by water and diluted alcohol. Tincture of galls does not render its infusion turbid, hence it probably does not contain the peculiar substances discovered in Peruvian bark. M. Carzoneri thinks that he has detected the febrifuge principle of the bark: it possesses alkaline properties, and he has named it Esculine.

Medical Properties and Uses. - The bark of the Horsechestnut tree has been long known, and employed as an astringent. It was first recommended in the cure of intermittents by Zannichelli ${ }_{+}$, and its febrifuge qualities have since been asserted by many others $\S$. Hufeland $\|$ asserts, that the following pow- der may be fairly substituted for Peruvian bark:

FACTITIOUS POWDER OF CINCHONA.

Take of bark of the Horse-Chestnut..

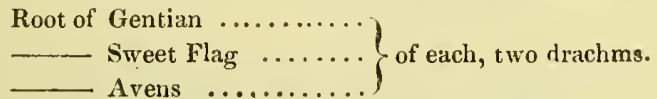

'To be made into a fine powder.

Van Mons If recommends the subsequent docoction as a valuable astringent, tonic, and febrifuge. In intermittent fevers, a cupful, with the addition of sixty or eighty drops of ether, is ordered to be given every two hours.

Take of Bark of the Horse-Chestnut, four ounces;

Water............... two pints.

Boil, and repeat the operation a second time with the same quantity of water; strain the two hoiling liquors, and reduce to one pint by evaporation; then add an ounce of white sugar.

* Murray, App. Med. Vol. iv. p. 68.

+ Annales de Chimie, lxxvii.

† J. Jac. Zannichelli, Lettera intorno alle Facolta dell' Ippocastano, etc.

$\S$ By Leidenfrost and Peipers, Diss. de cort. Hipp. I763; Junghans, 1)iss. de nucis vomiræ et cort. Hipp. virtıte mel. 1770, p 25; Coste and Willemet, Essais sur les Plantes indigenes, p. 57 ; Saburet De La Varniere, Journ. de Medec. tom. xlvii. p. 324; Turra, Della febrifuga Faculta dell Ippoc. 1780 ; Buchholz, Uber Antisept. Inbst. 1776 .

II Hufeland, Armen. Pharm Bcrlin, 1825.

I Pharm, swediaur. Brussels, 1817. 
Notwithstanding the value set upon this bark by the authors just cited, it has now fallen greatly into disuse. In decoction, lowever, it is occasionally employed as a lotion to phagedenic ulcers *; and if a small quantity of the powder be used as an errhine, it produces a discharge from the nose, which, in some complaints of the head and eyes, is found of considerable benefit $\dot{\varphi}$.

The roasted nuts have been found beneficial in atonic uterine hemorrhages. For this purpose they are pulverised, and an ounce and a half boiled in six ounces of water reduced to three, which the patient takes in two doses, before and after dinner $¥$.

The dose of the powder is from two to four scruples every three hours.

* Coste et Willemet Diss. de Cort. Hippocast. 1763.

+ Woodville's Med. Bot. vol. ii. p. 351.

‡ Jourdan Pharmacopée Univ. tom. ii. p. 14. 


\section{$\mathrm{XLV}$.}

\section{ANTHRISCUS CEREFOLIUM.}

\section{Garden Chervil or Beaked Parsley.}

\section{Class V. Pentandria,-Order II. Digynia.}

Nat. Ord. Umbelitfere.

Gen. Char. Calyx an obsolete margin. Petals obcordate, inflexed at the point. Fruit contracted at the side, beaked; carpels without ridges, the beak alone with five ridges. Seeds nearly convex, deeply furrowed in front. General involucre none; partial manyleaved.

Spec. Char. Umbels lateral, sessile. Leares tripartite, decompound. Fruit shining, ovate, subulate.

\section{S Y NON Y M E.}

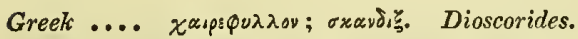

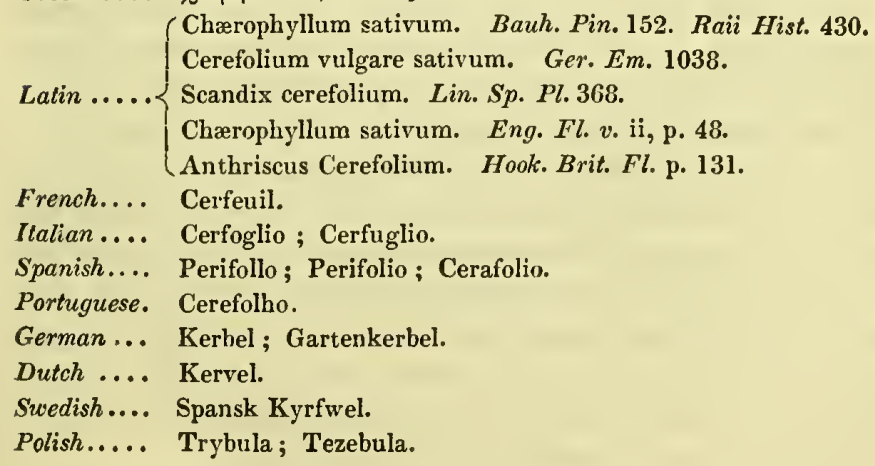

Description. - The root is fusiform, about the thickness of the little finger, reddish externally, white within, somewhat branched, and very fibrous towards the extremity. The stem 
is cylindrical, glabrous, striated, fistulous, and. branched, and rises to the height of about two feet. The leaves are alternate, somewhat amplexicaul, twice or thrice winged; the leaflets are pinnatifid, ovate-cordate, with deep incised segments, and of a delicate pale green colour. The flowers are disposed in umbels placed laterally at the summit of the branches, composed of three or four pubescent rays; the umbellules are small and furnished with an involucre of about three linear leaves. The calyx is an indistinct rim. The five petals are white, unequal, cordate, spreading, and slightly inflexed at the point. The filaments are also five, thread-shaped, spreading, and tipped with roundish anthers. The germen is inferior, oblong, with two short awl-shaped styles terminated by simple stigmas. The fruit is large, smooth, and shining, linear, tapering upwards, with a short angular beak marked with five ridges, and is crowned by the flattened disk to which the styles adhere; the carpels are destitute of ridges. The seeds are oblong, smooth, deeply furrowed in front, and nearly black when ripe. Plate 11, fig. 3, (a) floret magnified; (b) the fruit; (c) the carpels as they separate at maturity.

This species of Chervil is found wild in hedges and about gardens, from which it is thought to have escaped, being very frequently cultivated as an esculent vegetable. It is annual, and flowers in June and July.

The generic name is a title given by Pliny to a plant nearly allied to this, but the derivation is unknown. The garden Chervil is sometimes included in the genus chærophyllum. The common beaked parsley, or rough Chervil (Anthriscus vulgaris), bears a near resemblance to the species now before us, and was gathered in mistake by the Dutch soldiers who were in England in 1745, and some of them were poisoned by it. The different structure of the fruit is a sufficient distinctive mark, when that can be found, being ovate, conical, and covered with hooked bristles. If the fruit is not perfected, the uniform petals, the many-rayed umbels, and the stems swollen beneath the joints, are distinguishing characters.

Culture. - The seeds may be sown in drills from six to nine inches apart, or broad cast. The best time for sowing is in autumn, soon after the seerls are ripe; the plants thus raised continue green all the winter, and flower about the end of April. 
Qualities and general Uses.-This plant was formerly much used as a salad and pot-herb. It is a pleasant addition to soups, \&c., and is reckoned rery nutritive and wholesome; a very slight boiling is required, otherwisc it loses its taste and virtues.

Chervil has an agreeable aromatic smell and a moderately penetrating taste, resembling that of anise. Its aromatic properties are very fugitive, being speedily dissipated by boiling and desiccation; but the greater part of its virtues are extracted by infusion either in alcoliol or water.

Medical Propertres and Uses.-Chervil is slightly aromatic, gently aperient, diuretic, and lactiferous. Ehrliart* says it is serviceable in obstructions of the mesenteric glands. Geoffroy ${ }^{\top}$ extols it for removing obstructions of the viscera, for preventing the formation of calculi in the kidneys and bladder, for promoting the menses, and for the cure of cutaneous diseases. $\mathrm{He}$ also asserts that it favours the absorption of extravasated blood, both external and internal. Haller + employed it in visccral obstructions also. Neither, according to Lange $\S$, is it less approved of in asthma, consumption, and slow fevers, the juice been given alone, or mixed either witlı goat's milk or gruel; others prefer that the herb should be boiled in whey and strained, of which a pint should be drunk every morning, or that the juice should be evaporated to an extract, and an ounce taken during the day $\|$. By Riverius $\uparrow$ it was much used in dropsy, and by Plenck** in scrofula. Lastly, Geoffroy considered it hurtful in coughs and spitting of blood, which he found to increase, and even to be brought on by long-continued use.

'The extcrnal application of Chervil, eitler in poultices or the juice itself, has been found beneficial for many complaints. In the form of a cataplasm, in combination witl fresh alder leaves or linseed meal, it dissipates the milk and tumefactions in the breasts of puerperal women. It should be applied to the bare

* Ehrhart, Pflanzenhist, tom. v. p. 218, sq.

+ Geoffroy, Tract. Mat. Med. p. 295.

¥ Halleri, Hist. plant. Helv. n. 747.

$\S$ Lange, Brunsv. dom. p. 252.

l| Darel, Socken-A pot. p. 68, p. 191.

- Prax. Med. 1. ii. cap. 6, de hydrope.

* Plenck. Mat. Chir. p. 300. 
part, as warm as can be borne without giving pain, and repeated twice or thrice a day. Combined with hemlock it is useful against gouty affections of the joints*. Applied in poultice to the abdomen it has been found to produce a great flow of urine, where there had been previous retention $t$. Chomel's + liniment,

Take of juice of chervil and olive oil-equal parts,

forms a good application to relieve the pain of piles. He also recommends, with the same view, the steam of this plant, boiled in milk; the patient sitting over a vessel containing a well-heated decoction. A cataplasm mixed with gruel may be employed for the same purpose, as also for dispersing boils and the like.

The juice is pressed out of the fresl plant, previously bruised, and purified by a slight boiling. Three or four ounces may be given at a dose, and repeated if necessary every four hours.

\section{CATAPLASM OF CHERVIL.}

Take of fresh Chervil leaves, bruised, three ounces;

Water ............... one pint.

Boil for half an hour, strain off the liquor, bruise the leaves into a pulp, and then add half an ounce of olive oil or of lard.

\section{DECOCTION OF CHERVIL.}

Take of fresh Chervil leaves, two ounces;

Water ......... one pint.

Boil for a quarter of an hour, and strain.

Dose.-A quarter of a pint, mixed with an equal portion of milk, three times a day.

* Lange, Brunsv. dom. p. 252.

+ Simon Pauli, in Geoff. Tract. Mat. Med. p. 296.

† Chomel, L'Hist. Plant. Usuell, tom ii. p. 185. 


\section{XLVI.}

\section{POTENTILLA REPTANS.}

\section{Common Creeping Cinquefoil.}

\section{Class XII. Icosandria.-Order III. Polygynia.}

\section{Nat. Ord. Rosaceæ.}

Gen. Char. Calyx ten-cleft, segments alternately smaller. Petals five. Fruit consisting of numerous minute grains or nuts placed upon a small dry receptacle.

Spec. Char. Stem filiform, creeping. Leaves quinate; leaflets obovate, approaching to wedge-shaped, serrated. Peduncles axillary, single-flowered.

SY NON YMES.

Greek....... $\pi \varepsilon v \tau \alpha \varphi \nu \lambda \lambda o v$.

Latin..... $\left\{\begin{array}{l}\text { Quinquefolium majus repeus. Bauh. Pin. } 325 . \\ \text { Quinquefolium vulgare. Ger. Em. 987. } \\ \text { Pentaphyllum vulgatissimum. Raii. Syn. 255. } \\ \text { Fragaria foliis quinatis, \&c. Hall. Stirp. Helv. 11. } 1118 . \\ \text { Potentilla reptans. Lin. Sp. Pl. 714; Eng. Bot. t. 862. }\end{array}\right.$

French..... Quinte-feuille.

Italian..... Cinquefoglie.

Spanish and
Portuguese ..

German.... Fünffingerkraut; Handblatt.

Dutch...... Vyfvingerkruid.

Danish..... Femfingerert.

Polish ...... Pieciornik.

Swedish ..... Femfingerœrt.

Russ. ..... Schabnik.

Description.-The root is perennial, long, tapering, cylindrical, with but few fibres, externally of a yellowish or reddish brown colour. The stems are numerous, slender, long, pro- 
strate, rooting at the joints. The leaves are opposite, quinate, sometimes of seven leaflets, unequal, obovate, serrated, hairy, and sessile, on long axillary hairy petioles, at the base of which the stipulæ are inserted. The flowers are placed singly on long slender peduncles. The calyx is divided into ten segments, five of which are alternately smaller and exterior to the rest, and frequently recurved. The corolla consists of five obcordate yellow petals inserted into the calyx by short claws. The stamens are about twenty in number, with short tapering filaments, tipped with roundish two-celled anthers. The germens are numerous, superior, globose, and form a conical head; each is terminated by a filiform ascending style, surmounted by a blunt downy stigma. The fruit consists of numerous minute nuis or grains, placed on a small, elevated, dry receptacle. Plate 10, fig. 1, (a) the calyx ; (b) a petal cletached; (c) a single stamen.

The creeping Cinquefoil is a native of Europe, as far north as Sweden. The genus comprehends a large number of pretty vivacious plants, many of them natives of Siberia. It is common in meadows and pastures, and by road sides, flowering from June to the end of August.

The name is derived from potens, powerful, in allusion to the medical properties of some of the species. The origin of the common name is sufficiently obvious.

Qualities and general Use.-The only known use to which the cinquefoil has been applied, is that of tanning leather, for which purpose it has been used in some parts of the continent. The external or cortical part only is employed, and it is said to impart a fine grain to calf leather. The plant is eaten by horses, cows, goats, and sheep, but is refused by swine.

The roots have a bitterish styptic taste, and give out their astringent matter both to water and spirit. In these respects it nearly resembles the tormentil, but is less powerful.

Medicar, Properties and Uses.-The roots of this plant were much used in intermittent fevers by the ancicnts, the efficacy of which in those cases is alluded to by Hippocrates*. Ray $†$ asserts that the peasantry of his tine used it for the same

* De Morb. 1. 2. p. 473. Foës.

+ Ray, Hist. plant. tom. 1. p. 610. 
purpose, and Senac* bears testimony also on the same point. A drachm of the powder in an ounce of wine should be taken just before the paroxysm. Cinquefoil is now scarcely ever exhibited in fevers, but it has for many ages been employed as a remedy in all diseases where astringents were deemed necessary, particularly diarrhœea and dysentery $\downarrow$, spitting of blood, bleeding at the nose, and in profuse menstruation or flooding. By the French $\ddagger$ practitioners it is also reputed valuable for catarrhous affections, coughs, jaundice, calculi, and ulcers in the kidneys.

Externally, the expressed juice of the fresh root, or a strong decoction, may be usefully employed in chronic inflammation of the eyes; and the latter in foul ulcers of the mouth or throat, scorbutic state of the gurns, and all malignant ulcers.

The leaves of cinquefoil possess the same qualities as the root, but are much weaker. The cortical part $\ddagger$ of the root should be selected, which, when dried and reduced to powder, may be taken from a scruple to a drachm at a dose.

\section{DECOCTION OF CINQUEFOLL.}

Take of bark of Cinquefoil root, one ounce;

Water............ one pint and a half.

Boil gently until reduced to a pint.

This may be used externally and internally in all ordinary cases. 'The dose, a quarter of a pint, twice or' thrice a day.

* Senac, De recond. febr. interm. nat. p. 185.

† Chomel, L'Hist. Plant. Usuell. tom. 2. p. 296.

$\mp$ Flore Economique, p. 450 . 


\section{XLVII.}

\section{SALVIA PRATENSIS. \\ Meadow Clary or Meadow Sage.}

Class II. Diandria.-Order I. Monogynia.

Nat. Ord. Labiate.

Gen. Char. Calyx two-lipped, tubular. Corolla labiate, the tube dilated upwards, and compressed. Filaments with two spreading branches, one only bearing a perfect anther.

Spec. Char. Lower leaves cordate-oblong, crenate, stalked; those of the stem sessile, amplexicaul. Bracteæ nearly as long as the calyx. Corolla thrice as long as the calyx, viscid at the summit.

S Y N O N Y M E.

Latin .... $\left\{\begin{array}{l}\text { Gallitrichum silvestre vulgo. Bauh. J. iii. b. } 311 . \\ \text { Orminum sylvestre. Fuchs. 547. c. } 217 . \\ \text { Horminum sylvestre Fuchsii. Ger. Em. } 769 . \\ \text { Sclarea pratensis, foliis serratis, flore cœruleo. Dill ap. Raii } \\ \begin{array}{l}\text { Syn. } 23 \% \\ \text { Salvia pratensis. Lin. Sp. } P l .35 .\end{array}\end{array}\right.$

French .. Sauge des Près.

Italian.... Salvia di prato.

Spanish .. Salvia silvestre.

German .. Weisensalbei; Scharlei.

Dutch .... Veld-Salie.

Description.-The root is perennial. The stem is quadrangular, branched, leafy, tinged with purple towards the summit, and varying from eight inches to two feet in height. The lower leaves are cordate-oblong, irregularly crenate, wrinkled, veiny, and stand on moderately long footstalks; the upper are sessile, or nearly so, acuminate, embracing the stem. The flowers ter- 

minate the stem and branches in large spikes of beautiful purplish blue flowers, about six in a whorl, with a pair of heart-shaped acuminate bracteæ at the base of each whorl. The calyx is striated, beset with glandular hairs, and formed of two unequal lips, the upper of which is three-toothed, the corolla is large, blueish purple, labiate, the tube dilated upwards; the upper lip concave, viscid at the summit; the upper lip threelobed, the middle lobe largest, notched. The two filaments are transversely attached to a footstalk, one only of each bearing a one-celled anther. The germen is superior and four-cleft, surmounted with a filiform curved style and a bifid stigma. The seeds are four, apparently naked*, and lodged in the bottom of the persistent calyx. Plate 13, fig. $1,(a)$ lower leaf; (b) calyx; (c) stamens; $(d)$ pistil.

Meadow Clary + occurs in dry pastures and about hedges in some of the English counties, but is rather a rare plant. It has been found in Surrey and Sussex plentifully; near Cobham, in Kent ; Wick-cliffs, Gloucestershire; and between Middleton, Stoney, and Audley, Oxfordshire. It is very commonly cultivated in gardens, and flowers in July.

The name is derived from salvo, to save or heal, on account of the supposed healing properties of some of the species.

There is one other British species, the Wild Clary (Salvia verbenacea), which is rather frequent in dry, chalky, or gravelly pastures. The flowers are much smaller than in the Mearlow Clary, the leaves deeply serrated, and the whole plant darker coloured. It is aromatic, and the seeds mucilaginous.

The genus includes about 170 species, some of which, as $S$. formosa and S. splendens, are very ornamental; others useful, as S. officinalis, which will be noticed hereafter. The Apple-bearing Sage (Salvia pomifera), a native of Candia, is infested by an insect which produces excrescences as large as oak-galls. The flowers of the Glutinous Sage (Salvia glutinosa), are used in Holland to flavour the Rhenish wines. The Annual Clary (Salvia Horninum), was once held in considerable repute as a medicine, and its mucilaginous seed bruised, and a small

* i. e., Closely covered by the pericarp (Gymnospermous).

$\uparrow$ This species has been selected for illustration because it is indigenous, otherwise the True Clary (S. Sclarea) has been held in greater esteem as a medicinal agent, and is certainly more potent in its effects. 
quantity put under the eye-lids, was used to remove any sand or dust that might have lodged there*.

Qualities and general Uses. - Bechstein observes that this plant, when used as a substitute for hops, imparts an agreeable flavour to beer and wine. It may also be used in tanning leather, and for dyeing a permanent dark brown.

The leaves and flowers have an agreeable odour and an aromatic and somewhat bitter taste. The seeds are slightly bitter and mucilaginous. Both water and rectified spirit extract the virtues of the plant.

Medical Properties and Uses. - The leaves and flowers of this plant have been recommended in common with those of Common Clary $t$, both internally and externally, for the cure of windy colic, fluor albus, hysterical affections, and suppression of the menses ${ }_{+}$. For these purposes they are employed in decoction either with water or beer; or they are otherwise combined with different herbs and made into a spirituous tincture or a compound infusion.

Externally, it has chiefly been employed in fluor albus, in the form of an ointment made with fresh butter, to be plentifully rubbed in all round the seat of the disease.

\section{DECOCTION OF CLARY.}

Take of leaves or flowers of Clary, two ounces,

Water or beer ....... one pint.

Boil gently for half an hour and strain.

Two to four ounces should be taken twice or three times a day.

\section{COMPOUND DECOCTION OF CLARY.}

Take of Leaves or flowers of Clary

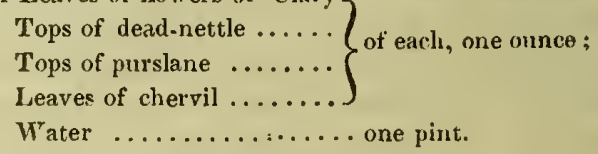

Boil gently for half an hour and strain.

Geoffroy recommends that half a pint of this decoction, mixed with an equal portion of veal broth, should be taken

* The Wild Finglish Clary before mentioned was used for the same purpose, hence the name Oculus Christi.

† Salvia Sclarea. Lin. Spec. Pl. p. 38.

¥ Murray; Appar. Medic. tom. ii. p. 204. 
every night and morning by women labouring under fluor albus. He also approves of half a pint of the following infusion to be taken every night and morning for the same purpose.

$$
\text { INFUSION OF CLARY. }
$$

Take of Leaves or flowers of Clary

Dead-nettle ..........

Boiling water ........ half a pint.

Pour the water on the herbs, let it stand until cold, strain, and then sweeten with a little sugar.

\section{COMPOUND TINCTURE OF CLARY.}

Take of Leaves and flowers of Clary, dried, two ounces;

Chamomile flowers .......... one ounce ;

Avens root $\ldots \ldots \ldots \ldots \ldots$ half an ounce;

Caraway seeds, bruised....... ? two drachms each ;

Burdock seeds, bruised ......... three drachms;

Proof spirit .............. two pints.

Macerate for fourteen days; and then filter. Gin, if good and of a proper strength, is a convenient substitute for spirits of wine.

To a person in violent hysterics, or suffering from windy colic, a small wine-glassful of this tincture may be given, diluted with at least an equal. or twice the quantity of water. 


\section{XLVIII.}

\section{GALIUM APARINE.}

Cleavers or Goose-grass.

Class IV. Tetrandria.-Order 1. Monogynia.

Nat. Ord. Rubiaces.

GEN. Char. Calyx an obsolete superior margin. Corolla rotate, four-cleft. Fruit a dry two-lobed, indehiscent pericarp.

Spec. Char. Leaves six to eight in a whorl, lanceolate; the margin and midrib hispid with reflexed bristles. Stem weak, hispid at the angles. Fruit hispid.

\section{S Y NON Y M E S.}

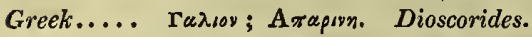

Latin..... $\begin{aligned} & \text { Aparine vulgaris. Bauh. Pin. 334. } \\ & \text { Aparine. Ger. Em. 1122. Ruii. Syn. } 225 . \\ & \text { Galium Aparine. Lin. Sp. Pl. 157. }\end{aligned}$

French .... Grateron; Rieble; Philantrope.

Italian.... A parine; Speronella.

Spanish.... Aspergula ; Amor del Hortelano.

Portuguese. Amor do Hortelano.

German.... Klebekraut ; Kletterndes Labkraut.

Dutch...... Kleefkruid; Klet; Klatte-Klaauwen.

Danish.... Snerre; Snerregræss.

Swedish.... Snarjegras; Snarpegras.

Polish .... Spona ; Ostrzyka.

Russ...... Smolnaja Trawa.

Hungarian. Ragadaly; Ragado-fu.

Description.- The roots are annual, slender, somewhat foursided, and furnished with a few short delicate fibres. The stems are weak, trailing, jointed, quadrangular, very rough at the angles with reflexed bristles, and from two to six feet long, straggling among bushes. The leaves are plane, lanceolate, hairy 
above, glabrous beneath, hispid at the nidrib, mucronate at the extremity, and arranged in whorls of about eight together, in a stellate form. The flowers are few, small, and white, on two or three short, simple footstalks, arising from the axils of the leaves. The calyx is an indistinct four-toothed margin. The corolla is monopetalous, wheel-shaped; with four deep, acute segments. The filaments are four in number, awlshaped, arising from the base of the corolla, shorter than the limb, and terminated by two-celled anthers. The germen is inferior, two-lobed, with two divaricating styles, and clavate stigmas. The fruit is a dry, two-lobed, indehiscent pericarp, (consisting as it were of two globose bodies united together,) with two cells and two seeds. Plate 12, fig. $4,(a)$ the entire flower magnified; (b) the pistil ; $(c)$ the fruit.

This well known plant is found in almost every hedge, and is distinguished by the harsh hooked bristles of its fruit, which lay hold of the coats of animals, and thus mainly contribute to the preservation of the species. It flowers from May to August.

The generic name is derived from $\gamma \alpha \lambda \alpha$, milk, one of the species having been employed to curdle milk. By the older botanists, this plant was called Aparine, from amaspw, to lay hold of, because of the hooked bristles which attach themselves to passing objects. In some parts of the country it goes by the name of catch-weed and scratch-weed, and the fruit is called burs.

Qualities AND General Uses.-The stalks of this plant are used in Sweden as a strainer for milk; the bristles with which it is covered, effectually preventing the passage of hairs and other extraneous bodies. Dioscorides informs us, that the shepherds made use of it for the same purpose in his time. The root, in common with many others of the natural order Stellatæ, will dye red, and like the madder tinge the bones of animals that feed upon it. The seeds roasted, bear a considerable resemblance to coffee, "and have been used as a substitute for that grain. The plant, when dry, proves injurious to cattle, on account of its rigid curved hairs; but in its growing state, it is eaten by all animals except swine. Young geese are extremely fond of it; hence, one of the popular names, Goose-grass. 
The leaves and stalks yield, upon expression, a large quantity of juice, which is green and turbid at first, but when depurated becomes clear and of a reddish colour. Inspissated to the consistence of an extract, it manifests a pungent though fugitive saline bitterness.

Medrcal Properties and Uses. - Goose-grass, like many other plants, has from time to time had its various advocates, although in the present day its efficacy is much questioned. Its expressed juice, however, has been given with decided advantage as an aperient, diuretic, and antiscorbutic medicine*. The celebrated Theodore 'Torquet de Mayerne $\psi$ found it extremely serviceable in the cure of dropsies, particularly in the earlier stage of the disease. For this complaint he directed three ounces of the juice to be mixed with wine, and taken twice a day. Ray attests that a decoction of the plant in white wine was found useful in nephritic cases, tended to expel calculi of the kidneys + ; and subdued enlargements of the spleen $\S$. Simon Pauli\| says that in Denmark the distilled water proved beneficial in affections of the chest and in hypochondriacal cases, whereas others $\mathbb{\uparrow}$ doubt its utility altogether. Durand ** also prescribed it in jaundice, obstructions of the liver, and in diarrhœa. As a remedy in scrofula this plant was long in repute, for which complaint it was especially recommended in Italy by Gaspari $\uparrow+$, both externally and internally, but the benefits said to have been derived from its use are not confirmed by others ++ . In gravel, Chomel $\S \S$ considers a decoction to ameliorate the irritability of the bladder, which opinion appears to be borne out by the remarks of Ray. In this and other countries the juice of the

* Dr. Cullen included the Aparine among the astringents, but it does not in any respect agree with the peculiar properties of that class of medicines. Cullen's Treat. Mat. Med. vol. ii. p. 37.

+ Prax. Med. pars 1. p. 390.

+ Ray, in Geoff. Tract. Mat. Med. tom. iii. p. 103.

$\S$ Ray, in Flore Médicale, tom. iv p. 68.

\| S. Pauli, in Geoff. Tract. Mat. Med. tom. iii. p. 103.

ๆ Flore Mlédicale, tom. iv. p. 68.

** Flore Economique, p. 238.

+t Osservazioni Storiche, Mediche, \&c. 1731. p. 17. $\mathrm{sq}$.

廿+ Parr's Med. Dict. art. Aparine.

SS I’lIist. Plánt. Usuell. tom. i, p. 444. 
Cleavers is made one of the "spring juices," and taken by the country people for scorbutic * complaints, for which it was also recommended by Dr. Edwards $\uparrow$. Lastly, from the root of the plant (as above observed) giving a colouring to the bones of animals, Glisson + , Roberts, and others imagine that its employment proves serviceable in rachitis or rickets.

It is not so much for its internal use that the Goose-grass is now held in estimation as for its external application. The herb well bruised and mixed with lard, so as to form a cataplasm, may be found available in all swellings and indurations, more particularly in glandular $\$$ and scrofulous $\|$ cases; but for no disease is it so celebrated as for cancer. "Its application to cancerous ulcers has in some instances been attended with a complete cure. As cancer, however, depends upon a peculiar state of the constitution, it can scarcely be expected to be removed by merely topical applications; still, whatever can be found to cleanse the unhealthy surface of these sores, and to remove the offensive effluvium, which is by no means the smallest calamity resulting from this formidable disease, is a valuable acquisition to the suffering patient. Not only the cancerous odour, but the pain also is generally taken away by this application, and the life of the patient prolonged and rendered more comfortable. I I have seen a most extensive and foul cancer, the stench and pain of which were hastening the unhappy victim to the tomb, so that the utmost period of existence that could be rationally expected, was not more than two or three weeks, which in two days was so changed by this application, that the horrible smell which had infected the whole house for months past was not to be perceived, and the pain, which had driven sleep from her couch for almost as long a period, was entirely removed. The surface of the ulcer, in a few days, was clean and healthy, and shortly after made some progress towards healing. The life of the patient was prolonged to nearly twelve

* Hill's Hist. Mat. Med. p. 387.

+ Treatise on the Goose-grass, or Clives, and its efficacy in the cure of the most inveterate Scurvy. 8vo.

¥ Flora Medicale, tom. iv. p. 68.

§ Gaspari, Osservazioni Storiche, p. 20.

|| Dioscorides. Mat. Med. lib. 3. cap. 104.

- J. A. Waller, R.N. Brit. Dom. Herl. p. 90. 
height of one or two feet. The lower leaves are numerous, linear, channelled, acute, entire, glaucous ; those of the stem are shorter, and placed in pairs at the joints. The flowers are solitary, on the tops of the stalks, and form a kind of panicle. The calyx is tubular, five-toothed at the summit, and surrounded at the base with four imbricated, very short, ovate, sub-mucronate scales or bracteæ. The corolla consists of five flesh-coloured * petals, broad, patent, crenated, and furnished with long claws. The ten filaments are longer than the calyx, spreading towards the summit, and support oblong, compressed anthers. The germen is oval, with two subulate styles, longer than the stamens, and terminated by revolute tapering stigmas. The capsule is cylindrical, one-celled, opening by four teeth, and containing many roundish, compressed seeds. Plate 14, fig. 3, (a) a single petal, with its claw ; $(b)$ the calyx opened to show the pistil ; (c) the fruit.

This fragrant plant grows on old walls and ruins $\dagger$, as at Norwich, and on the castles of Deal, Sandown, Rochester, \&c., flowering in July. It is frequently cultivated in gardens, and is very generally known and esteemed.

The generic name is derived from $\delta$ los, of Jupiter, and avtos, the flower, expressive of the high value which was attached to these beautiful plants. This species was named Caryophyllus by the ancient writers, on account of the similarity of its odour to that of the clove + , which was called by the Arabs Garunfel, meta-

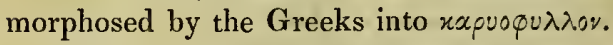

The genus to which this plant belongs is very extensive, and is valued both for the beauty of its flowers and for the evergreen nature of their foliage. The favourite carnation,-

$$
\text { "The curious, choice, Clove July-flower," }
$$

is generally allowed to have sprung from the Clove-pink, which Chaucer calls "cloue gilofre," and recommends as good-

$$
\text { ___ " to put in ale, }
$$

Whether it be moist or stale."

* In its cultivated state the flowers assume a deep crimson colour, and are preferred for medicinal purposes. The petals must be picked when the flower is fully blown.

$\dagger$ Upon the ancient archway of Weston-hanger. Mr. W. Hutchinson, in G. E. Smith's Phanog. Plants of East Kent.

† Caryoplyyllus aromaticus, Linnceus. 


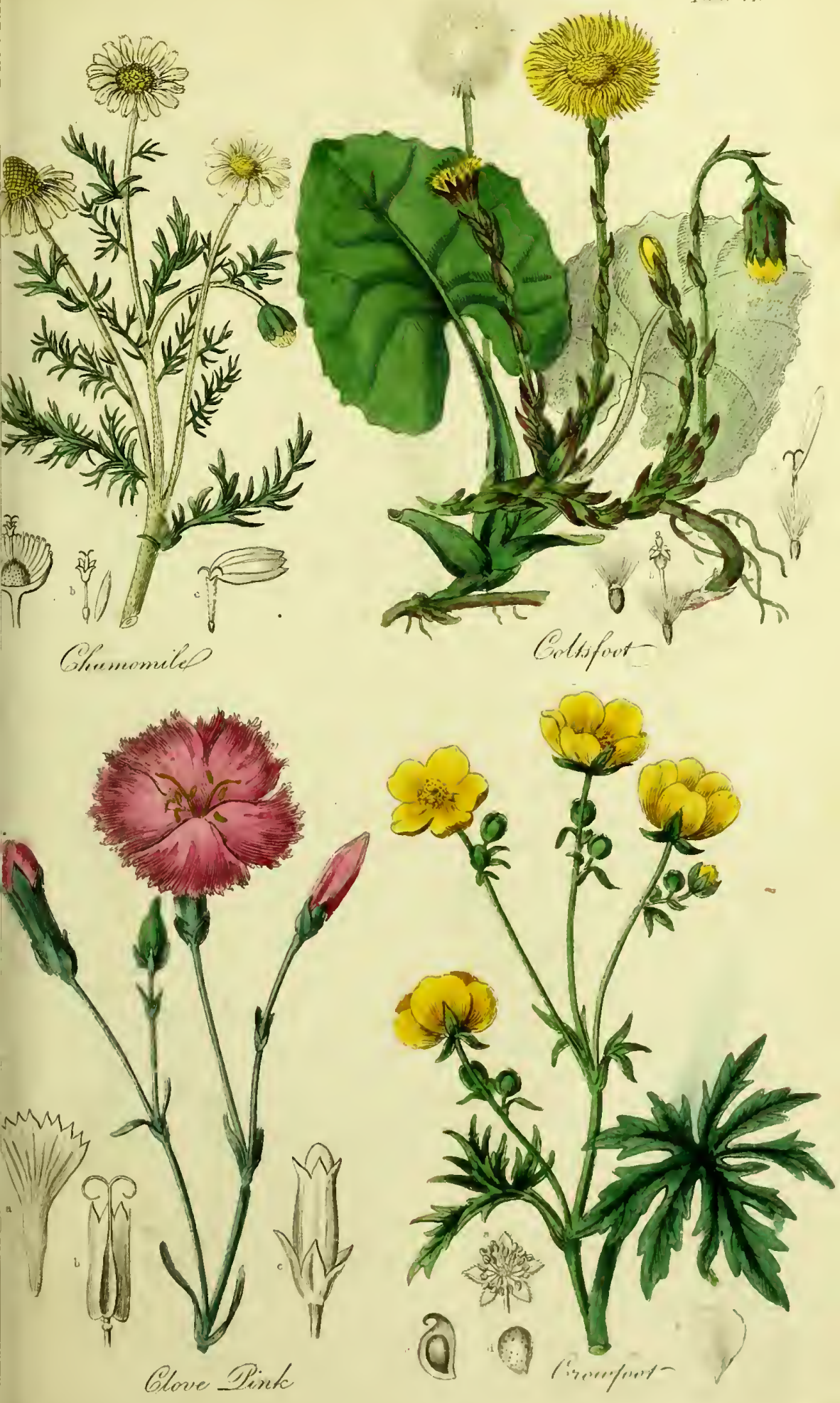



Spenser and Ben Jonson generally designate the plant by the name of "Sops in wine", it being customary in their time to infuse the flowers in wine for the sake of the spicy flavour they impart :

" Bring hether the pincke and purple cullambine

With gelliflowers;

Bring Coronations and Sops in wine!"

Shepherd's Calendar.

" Fair ox-eye, goldy-locks and columbine

Pinks, goulands, king-cups and sweet sops in wine."

Pan's Anniversary.

Qualities.-The odour of the petals is pleasant and aromatic, somewhat resembling that of the clove-spice. The taste is slightly bitter and sub-astringent, and is rendered more powerful by drying. On distilling the fresh flowers with water, the distilled liquor proves considerably impregnated with their fragrance, but no essential oil separates: the remaining decoction is of a deep red colour, and yields, on being inspissated, a dark purplish red extract, of little or no smell, and of a bitterish, austere, sub-saline taste. Rectified spirit digested on the flowers, receives a much paler tincture, but extracts the whole of their sensible qualities. Acids redden the colour of the infusion, alkalies change it to green, and sulphate of iron renders it black.

Medical Properties and Uses.-The clove-pink was highly commended by the medical writers of former days as a cordial, sudorific, and anti-poison. The flowers are recommended by Dr. Hill *, "in all Disorders of the Head, in Palpitations of the Heart, and in nervous Complaints of whatever Kind. They have been also much praised in malignant and pestilential Fevers. Simon Paulli tells us, with an Air of great Certainty and Assurance, that he had cur'd great numbers of People of malignant and pestilential Fevers, by no other Medicine but a strong Infusion of these Flowers in Water, which he tells us is a powerful Sudorific and Diuretic, and that it at the same Time comforts the Patient instead of weakening him." For their cordial and cephalic properties they appear to have been especially esteemed $t$, and were much valued as a remedy of some virtue in

- Hist. Mat. Med. p. 431.

+ Thus Gerard says, that when they are made into a conserve, they are "exceeding cordiall, and wonderfully above measure comfort the heart." 
low putrid fevers, and "in all affections of the head and of the heart." * According to Murray $t$, they were prescribed for syncope, convulsions, trembling of the limbs, and for other complaints. Notwithstanding the testimony of our forefathers in favour of the efficacy of the clove-pink flowers in the diseases just cited, practitioners of the present day value them only for the fine colour and agreeable odour which they give to an infusion, syrup, \&c.

\section{INFUSION OF CLOVE-PINK.}

Take of the dried Petals, without the claws, one ounce;

Boiling Water................. one pint.

Macerate for a quarter of an hour in a lightly covered vessel, and strain.

This infusion contains, in the greatest degree, all the properties of the plant, and may be given with advantage in typhus fevers ; it is asserted to produce perspiration, and to increase the flow of urine. A tea-cupful may be exhibited every four or six hours.

$$
\text { SYRUP OF CLOVE-PINK }+ \text {. }
$$

Take of the fresh Petals, without the claws, one ounce;

Boiling Water .............. four ounces;

Refined Sugar ................ seven ounces.

Macerate the petals in the water for twelve hours, then add the sugar to the strained liquor, and dissolve it with a gentle heat.

An useful adjunct to cordial, antispasmodic, and saline mixtures, imparting to them a pleasing colour, and a slightly exhilarating property.

$$
\text { VINEGAR OF CLOVE-PINK } \$ \text {. }
$$

Take of Petals, without the claws, one ounce.

Vinegar................ sixteen ounces.

Macerate for fifteen days, strain and filter.

This will be found very agreeable to smell to in nervous head-aches, and extremely serviceable in contagious fevers to sprinkle in the rooms.

* Geoffroy, Tract. Mat. Med. tom. iii. p. 269.

+ Appar. Medic. vol. iii.p. 504.

† Syrupus Dianthi Caryophylli._Pharm. Edinb.

$\S$ Codex Medic. Paris, 1818. 


\section{COLCHICUM AUTUMNALE.}

\section{Colchicum, or Common Meadow-Saffron.}

\section{Class VI. Hexandria. - Order III. 'Trigynia.}

\section{Nat. Ord. Melanthacee.}

Gen. Char. Perianth single; tube very long, rising from a spathe; limb campanulate, six-parted, petaloid. Capsules three-celled; cells united at the base.

Spec. Char. Leaves flat, broadly lanceolate, erect.

$$
\text { S Y NONYMES. }
$$

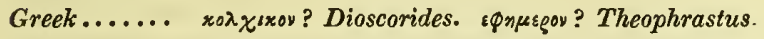

(Colchicum commune. Bauh. Pin. 67. Raii Hist. 1170; Syn. 373.

Latin...... Colchicum Anglicum purpureum et album. Ger. Em. 157. Colchicon officinis Hermodactylus. Trag. 759.

Colchicum sive Ephemerum strangulatorium. Lob. Obs. 69. Colchicum Autumnale. Lin. Sp. Pl. 485. Eng. Bot. t. 133.

French...... Colchique ; Colchique de l'Automne; Tue-chien; Safran batard.

Italian...... Colchico; Giglio matto; Strozza-cane.

Spanish...... Colchico; Villorita ; Quitameriendas.

Portuguese .. Colchico.

German.... Herbstzeitlose; Herbstblume ; Licht-blume; Nackte Jungfer; Wilde Safran.

Dutch....... Tyde-loosen; Naakte-Vrouwen.

Danish..... Nogne jomfrue.

Polish ...... Rozsiad; Cimowit.

Swedish ..... Nakna jungfrur; Tidlæsa.

Russ. ..... Beswremnoi zwjet.

Description.-The cormus * is fleshy, lactescent, covered with a brown membranous coat, and furnished at the base with many

" Commonly called solid bull. 
small fibrous roots. The leaves spring immediately from the cormus; they are long, erect, broadly-lanceolate, acute, entire, dark green, sheathing at the base, and united three or four together. The flowers proceed from the cormus, and are surrounded at the base by a membranous sheath ; they appear in autumn, anterior to the leaves, which are not developed until spring. The perianth (calyx) is single, petaloid, of a light roseate purple, with a very long narrow tube, arising immediately from the cormus,'and a six-parted limb, whose segments are oblong-ovate, obtuse, erect, and concave. The stamens are six in number, with white subulate filaments, inserted on the segments of the perianth; anthers oblong, versatile, yellow, turned outwards. The germen is situated at the bottom of the tube, in the midst of the cormus, supporting three long filiform styles, terminated by as many linear recurved and downy stigmas.' The fruit is a subsessile capsule, with three cells and three straight lobes, rather acute at the summit, connected at their lower part, and opening longitudinally on their inner face. The seeds are small, whitish, smooth, and rounded, with a membranous testa, and a dense fleshy albumen. Plate 13, fig. 2, (a) the capsule opening naturally ; $(b)$ the pistil; (c) the capsule cut transversely to shew the seeds.

The Colchicum is a native of the southern and most of the central countries of Europe, but is not enumerated in the Flora of Holland. It grows in moist rich meadows at Little Stonham and Bury, Suffolk; Filkins and Bradwell, Oxfordshire; near Devizes, Wiltshire ; the foot of the Malvern Hills, Worcestershire; it also occurs in Northamptonshire, Bedfordshire, Middlesex, Warwickshire*, and some other counties. Lightfoot gives "Alloa" as the only locality for it in Scotland. The flowers appear in September and October, before the leaves and fruit, which are not produced until the following spring.

This plant owes its generic name to Colchis, in Natolia, which abounded in this and other poisonous vegetables, and hence perhaps gave rise to some of the poetical fictions respecting the

* Miller says, "I have observed it in great plenty in the meadows in Warwickshire, at the beginning of September. The country people call the flowers $\mathbf{N}$ aked I.adies, because they come up naked, without any leaves or cover." A similar name is given them in other countries as may be seen in the list of sunonymes. 
enchantress Medea, who was not unfrequently called Colchis, from the place of her birth. On account of the great length of the flower-tube, the plant goes by the name of tube-root, in some parts of England. It is generally believed that the Colchicum Autumnale is the Hermodactylon of the ancients; this bulb was described as about the size of a small chestnut, flattened on one side, yellowish externally, white within, of a subviscid, farinaceous taste, and without odour. It was brought from Natolia and Egypt through Turkey. Linnæus*, on the authority of Bauhin, mentions it as the root of the Iris tuberosa, adding "the plant from which it is obtained is unknownTournefort and many others consider it a species of Iris, while some take it for the Colchicum variegatum!" The description given by Alexander of Tralles $\dagger$, as to its medicinal effects corresponds very nearly with the character of the Colchicum. He recommended it with other purgatives in gout, united with aromatics. Paulus Egineta + extols it as a specific in the same disease, as does Avicenna , who also recommends it to be applied to the part affected in the form of a cataplasm.

The economy of this plant is so interesting as to deserve especial notice. In the Coltsfoot the flowers are produced early in spring, and the leaves in the following summer; but in the Meadow-Saffron the flowers appear about the latter end of September, and in a short time perish, without leaving any appearance of leaves or fruit. The germen or ovary which was impregnated in autumn gradually developes underground, and finds a safe hybernaculum in the bulb. In spring the fruit rises on a short peduncle, together with the leaves, which perish before the end of June, when the seeds are ripe. In the mean time a new bulb has sprung from the side of the old one, and when this has perished, is ready to fulfil its destinerl office, by providing for the fecundation of the flower and the nourishment of the germ of a succeeding plant. There are, in fact, two

* Mat. Med. ed. Schreber, p. 44.

+ Libr. Med. xi. ed. Andernaci, p. 643, sqq.

† Ed. Torin. lib. iii. p. 237.

$\S$ Canon. Med. ed. F. P. Utinensem, vol. i. p. 333, (de hermodactylo,) Venetiis, 1608.-But his description will not apply to our plant. - "Hermodactylus est radix plantæe habentis rosas albas, et citrinas. Et aperitur in primis, quum aperiuntur fores; et existit in planitiebus montium et in angulis eorum et folia ejus expansa sunt super terram." 
germs from the same bulb, one lower, just described, producing the flower and seed, the other situated above, also furnished with a stem, but seldom bearing flowers.

Qualities AND Uses.-Prosper Alpinus* states that the Egyptian women fatten themselves with the Hermodactyl roots that are sold in shops, eating ten every day for a fortnight or three weeks, without experiencing any effect on the stomach or bowels, or any inconvenience, and the true Colchicum, of which we are speaking, varies greatly in its qualities. Krapf $\uparrow$ asserts that in Carniola, towards the end of Autumn, he has eaten whole bulbs, and experienced no disagreeable effect, except an ungrateful bitterness. On the other hand, it is affirmed by various writers to be very acrimonious and dangerous in its effects; but these discrepancies are to be attributed almost entirely to the time of year at which the bulb is dug up. Climate and soil have also their share of influence; and even when its baneful principle is most fully developed, by a very simple process it may be divested of all poisonous properties, and

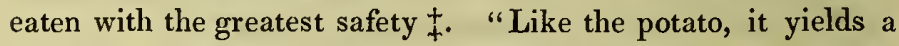
white friable, amylaceous fecula, which, after repeated washings, is by no means acrid. I have several times given a scruple of this fecula, dried in the sun, to a domestic fowl, without the slightest ill effect. Boiled in river water, it affords a brownish jelly, similar to that of sago." $\$$

From the preceding remarks it is evident that the proper time for taking up the bulb is just before it begins to develop the flowering organs or the new germ is projected, viz., in July and the beginning of $\Lambda$ ugust. At this time it is quite solid and firm, and when cut has a creamy appearance. It must also be remembered that the bulb, even when taken up at the proper season, if preserved entire, is subject to the same process which unfits it for medicinal purposes as though it remainea' underground $\|$. Dr. Thomson recommends that the

* Med. Ægypt. p. 234-253.

+ In Störck contin. experim. p. 233.

¥ See also p. 26 and 99.

$\S$ Bergius Mat. Med. vol. i. p. 291.

II This inconrenience might be obviated if some method could be ascertained of destroying its vitality. Perhaps a momentary immersion in boiling water might effect this. 
bulbs, immediately after they are dug up, be cut into transverse slices, not thicker than one-eighth of an inch, and dried by placing the slices on clean white blotting paper, distinct from one another, without heat, or at a very low temperature. The test of the drug being good and properly dried is the appearance of a blue colour on rubbing it with a little distilled vinegar and the alcoholic solution of guaiacum. The slices should be preserved in well-stopped bottles.

The recent bulb, when taken up at the proper season, is inodorous, bitter, hot, and acrid to the taste, and if a small portion be swallowed, a sensation of warmth is produced in the stomach. These properties are thought to reside in the milky juice which exudes when the bulb is cut transversely, and which contains a peculiar alkaloid, called Veratrine*. The other components are a fatty matter, gallic acid, a yellow colouring matter, gum, starch, sugar, inulin in great abundance, and a small quantity of lignin. Wine and vinegar are employed to extract its active qualities. Sir Everard Home ascribes the nauseating effect that is sometimes produced by the wine to a sediment formed in it, and which ought always to be removed.

Poisonous Properties. - There can be no doubt of the deleterious and sometimes fatal effects of the Meadow-Saffion upon animals, but contradictory statements are given on this point by different authors; some affirming that horses eat the flowers of the plant with impunity, while others state that they never touch it, let it be ever so plentiful. Cattle seldom eat the plant as it grows in meadows, but when dried and mixed with hay it has produced fatal consequences. "Fallow-deer, after eating it in their forage, have been seized with extreme pain and a copious flux of blood, and after death the stomach and intestines exhibited evident traces of inflammation and gangrene." + Scopoli+ mentions that a calf died from eating the flowers, and Störck § relates some experiments in which a small

- This substance also exists in the seeds, and was so called because it was found abundantly in White Hellebore (Veratrum Album). Geiger and Hesse (Journal de Pharmacie, xx. p. 164) have lately discovered a new alka. loid, which they have named Colchicia.

+ Bresl. Sam. 1720, p. 668.

‡ Flora Carn. ed. 1. p. 229.

§ De Colchico, p. 17, Exper. 17. 
quantity of the bulb proved fatal to dogs in a very short time. The old French name, Tue-chien, would seem to intimate that dogs are especially obnoxious to this poison.

In spring, when the seeds are ripe, they are liable to be swallowed by animals, and by adhering to the coats of the stomach, produce inflammation, which may terminate in death.

To the human frame colchicum is very deleterious. Several children have lost their lives in consequence of having eaten the seeds*, but only in the spring $\downarrow$, when the seed vessel is fully matured.

Respecting the properties of the bulb, authors have given very different reports. Haller + informs us that he found the root perfectly void of taste and acrimony. Krapf likewise says (as observed before) that he ate whole bulbs without feeling any inconvenience, except that of an ungrateful bitterish taste; and Kratochvill $\S$ gave it with impunity to several patients, in doses of two, three, and even four drachms. Störck\|, on the other hand, tells us, that by gently rubbing the root against the tip of his tongue, it rendered the part rigid, and almost void of sensation, for several hours. Ehrmann $\uparrow$, Marges**, Murray $+\uparrow$, and several other writers ++ , also bear testimony to the great acrimony of the colchicum, so that we can only reconcile these contradictory accounts by supposing the roots to vary according to their age, the soil in which they grow, the season of gathering them, and the manner in which they are preserved. The effects may also depend on the constitution of the person to whom it is administered $\S \S$.

Some well attested cases of the fatal effects of preparations of colchicum are related by observers worthy of confidence; among

- Orfila's Toxicology, vol. ii. p. 81, also Bressl. Samml. 1723, p. 679.

+ Beck's Medical Jurisprudence, 5th edit. p. 923.

† Hist. stirp. Helv. n. 1256.

$\S$ Kratochvill, Diss. de radice Colchici, Franc. ad Moen. 1764, p. 34.

II Störck, Lib. de Colch. p. 8, 9.

Tा Ehrmann, Diss. de Colchico, Basil, 1772, § 5.

** Marges in Journ. de Med. tom. xxiii. p. 32. sq.

†† Murray, Appar. Med. vol. v. p. 196.

華 Woodville's Med. Bot. vol. iii. p. 484.

§ Murray, Appar. Med. vol. v. p. 195. 
others, Mr. Dillen’s *, Mr. Fereday's †, Dr. Thompson's †, M. Chevallier's $\S$, and the case communicated to Dr. Duncan $\|$, are especially worthy of notice. Van Swieten, Garidel, and Peyer $\mathbb{T}$ also speak of various cases of poisoning by colchicum. Bernt ${ }^{* *}$ relates the case of two children who were poisoned by the seed. Agricola ft observes that two boys, after eating this plant, died in great agony. Fatal effects, according to Geiger's Journal ++, have followed the taking of an infusion of the flowers; and even, says Garidel $\S$, violent symptoms have been produced by taking only three of, the flowers in substance.

To obviate the deleterious effects of this powerful plant, immediately evacuate the stomach by copious draughts of oily and mucilaginous liquids, and give emollient clysters to sheath and sooth the rectum. After having excited vomiting very freely, administer acidulous fluids, coffee, and camphor. If necessary, bleeding must be resorted to.

Colchicum, either taken as a poison or exhibited as a remedial agent, is supposed to act through the nervous system by absorption, and by that medium exerting a peculiar influence on the arterial circulation \| \|. Sir E. Home 1 T found, by direct experiment, that its effects were the same, whether taken into the stomach or introduced into the jugular vein, only that in the latter case its action was more quickly developed. The prima vice usually exhibit appearances of inflammation; but according to Dr. Paris ${ }^{*} *$ this is no proof of its direct effects upon them.

Medical Properties and Uses.-The powerful influence of Colchicum as a medicine, admitting its identity with the Her-

* In Burnett's Medical Botany, vol. ii.

† Lond. Med. Gaz. vol. x. p. 161.

† Lancet, 1821, vol. vii. p. 281.

§ Journal de Chimie Médicale, viii. 351.

II Edinb. Med. and Surg. Journ. vol, xiv. p. 262.

Tा Flore Medicale, tom. iii. p. 64.

** Beiträge zur Gerichtl. Arzneik, iv. p. 246.

†† Jo. Agricola Ammonius, Medic. Herb. lib. i. p. 90 ; Nec non Ludovici Opera, p. 63.

\#+ Nagazin für Pharmacie, xxx. p. 237.

$\S \S$ Garidel, Plantes d' Aix, p. 123.

IIII T. Fereday, Lond. Med. Gaz. vol. x. p. 162.

ๆ ๆ Philosophical Transactions, 1816, p. 257.

*** Pharmacologia, 6th edit. vol. i. p. 248. 
modactyl of the ancients, has been known for ages. Occasional mention is made of it by the ancient writers both of Greece and Rome; but it appears the earliest particular account of its properties was given by Alexander and Paulus Ægineta, who regarded it as a remedy of great efficacy in gout*. Demetrius Paragomenus + , who wrote in the thirteenth century, likewise particularly mentions it.

In the reign of Queen Elizabeth, a translation of Wertzung's work $\$$ appeared, in which a very favourable account of the virtues of colchicum is given. More recently we find it enjoying its reputation, and entering into the "Pulvis Arthriticus" of Sir Theodore Mayerne, in which it was combined, among other et cetera, with the powder of unburied skulls (cranii humani insepulti); an ingredient which, it would appear, was not much relished by his Majesty King James the First, for it is added in a note-"N.B. In casu D. N. Regis qui $\alpha \nu \theta \rho \circ \pi \circ \varphi \alpha$; ous odit, cranium humanum poterit in ossium bubulorum rasuram permutari." What alteration the efficacy of the nostrum suffered from this change we are not informed $\S$.

Colchicum, duly preserved, is powerfully diuretic, purgative, and emetic. It is to the enterprising spirit of Störck that we are chiefly indebted for the knowledge of its diuretic virtue, who, by experiments with a vinous infusion of the fresh root on his own person, was fully satisfied, that if its deleterious acrimony were destroyed, it might prove an efficacious medicine; accordingly he invented an acetous preparation;

STÖRCK'S VINEGAR OF COLCHICUM.

Take of Fresh bulb of Colchicum, one ounce;

Vinegar ............. one pint.

Digest for forty-eight hours with a gentle heat, and strain.

Finding this article acrid to the taste, and that it constringed and irritated the fauces, and excited a slight cough, he added some honey to it ;

STÖRCK's OXYMEL OF COLCHICUM.

Take of Vinegar of Colchicum, one ounce;

Honey ............. two ounces.

Gently boil it down to the consistence of honey.

- See p. 189.

+ Ker's Medical Sketches.

† Praxis Medicinæ Universalis.

$\S$ Lond. Med. and Phys. Journ. vol. xlv. p. 219. 
Taken in doses of a drachm, gradually increased to an ounce or more, twice a day, he found it to promote a copious discharge of urine, without producing any inconvenience from its acrimony. Many other practitioners who employed this oxymel in dropsical complaints, also experienced its good effects, especially in Germany* and France + ; in England it has been less successful + , and is very generally thought a less efficacious diuretic than the squill $\$$.

The disorders for which colchicum is most celebrated are those of gout || and rheumatism, and that complicated form of disease called rheumatic gout. In France it has long been a favourite gout remedy; and is supposed to be the essence of M. Husson's far-famed "Eau Medicinale." " Sir Everard Home considered the following vinous infusion to be identical with the "Eau Medicinale"**; and found that when freed from its customary deposit, it acted (in doses of sixty or seventy drops) with much greater mildness, hence he extolled it as a complete and successful remedy.

\section{SIR E. HOME'S VINOUS INFUSION OF COLCHICUM.}

Take of Fresh bulbs of Colchicum, sliced, two ounces ; Sherry wine .............. twenty-four uunces.

Macerate with a gentle heat for six days.

Dr. Wilsontt, dissatisfied with the preparation in general use in 1815, proposed a secret tincture, which for some time, (with other nostra, was in great esteem. Both Dr. Williams 杖 and Sir C. Scudamore $\$ \S$ agree in condemning Wilson's preparation.

* Zack, Plenck, Collin, Krapf, Ehrmann, \&c.

† Marges, Planchoı, Du Monceau, \&c.

† Monro's Essay on Dropsy, p. 108.

$\S$ Woodville's Med. Bot. vol. iii. p. 485.

|| Quincy, speaking of the use of colchicum in gout, observes, "that it stands so much in the esteem of some writers, as to be dignified with the name of 'Anima Articulorum-the soul of the joints ;' because they believed it to be very efficacious in preventing chalky concretions in these parts." Quincy's Dispensatory, 11 th edit. 1739.

T The exact components of "Eau Medicinale" are not known; but its effects do not differ from those of the wine and tincture of colchicum.Hooper's Med. Dict. 6th edit. p. 401.

** See also Edinb. Med. and Surg. Journ. vol. xii. p. 501.

$+\dagger$ Wilson on Gout, lst edit. p. 42.

芰 Dr. Williams's Observations.

§§ Sir C. Scudamore's Observations, p. 32. 
Although a highly valuable agent in gout and rheumatism, colchicum must be very cautiously used; for although it has been taken by many persons with the best effects, acting almost as a charm in setting aside a paroxysm of the disease, it will sometimes produce the most distressing and even fatal effects. Mr. Bampfield * knew death to ensue on the following day after a drachm of the wine of colchicum had been administered over night, in two cases of dropsy; yet, he asserts, that he never saw such a consequence from its employment in gout; Mr. Bampfield, however, in the latter disorder employed small doses $\uparrow$. From the observations of Dr. Bardsley $\ddagger$ and of many others, the benefit derived from colchicum seems to depend upon its purgative operation. In some cases, however, it must be allowed that it removes the paroxysm of gout without any sensible operation. In proof of this fact Mr. Want has adduced several cases $\S$, and among the rest, that of the late Sir Joseph Banks $\|$; and in this opinion he is supported by Mr. Lignum $\uparrow$.

As a common gout and rheumatic remedy, the following formula** may be more depended on than the Eau Medicinale, or any of the more simple forms in which the colchicum is usually prescribed, as the ill qualities of the plant are corrected by articles which, of themselves, exert a very powerful action upon the matter which gives rise to that disorder.

Take of fresh bulbs of Colchicum ....... two ounces;

Avens root .. ? of each ........ one ounce;

Burdock root ............. one ounce and a half;

Sherry wine $\ldots \ldots \ldots \ldots \ldots \ldots$ a quart.

Infuse, for fourteen days, in a warm place, and then filter.

From one tea-spoonful to two, or even three, is a dose; but it will be best always to begin with the smaller quantity, and a little experience will soon teach the patient what is the precise dose

* Obs. on the Use of Colchicum.

$\dagger$ Op. cit. Nov. 1821.

¥ Hospital Facts and Reports, p. 118.

$\S$ Lond. Med. and Phys. Journ. vol. xxxii. pp. 312, 393, 491.

II Idem, p. 202.

Tा On the Effects of Tinct. Colch. in Gout.-Lond. Med. and Phys. Journ. vol. xxxiii. p. 264.

** Brit. Dom. Herb. p. 102. 
adapted to his constitution. This may be taken either in a glass of wine or in a small quantity of water, and should be received into a stomach as nearly as possible empty ; that is, either early in the morning, or four hours after breakfast, or any other meal. It will be highly necessary, during the exhibition of this remedy, to employ purgative medicines twice or thrice a-week. When the pain, whether of gout or rheumatism, continues, notwithstanding the first dose of the medicine, it may be repeated in four or six hours, to a third time, which will be generally found sufficient to relieve the most severe pain. When, however, the pain has ceased, the medicine should be discontinued, or its exhibition confined to once in the day.

M. Chelius * considers the beneficial effects produced by this medicine, in cases of gout and,rheumatism, to depend on its power of increasing the quantity of uric acid $\uparrow$ in the urine.

The late Mr. Haden + attributes to colchicum powerful influence in controlling the action of the heart and arteries, which opinion led him fiequently to substitute it for bleeding in inflammatory affections, such as pleurisy, pneumonia, \&c., and with apparent uniform success. In acute cases he gave from two to eight grains of the powder, with a scruple or more of sulphate of potash, in rose infusion, every four or six hours, increasing the dose after a few hours until either purging is produced on the second or third day, or the common black draught, or calomel, is given in addition. The medicine is now laid aside, if its effect on the disease be decided, or it is given in diminished doses, or one dose of six or more grains is given occasionally, with calomel at night. In chronic cases, he directed a dose of five grains and upwards every morning early, with a drachm of sulphate of potash, in a tumbler nearly full of warm water. In

* Bull. Univ. c. xiv. 100.

+ A person afflicted with gouty concretions in many of the joints, and especially in the knees, so as to be unable to move, took the colchicum wine : before its use, the uric acid, either free or combined in the urine, was 0.069 ; on the fourth day after the first employment of the medicine it had increased to 0.076 ; on the eighth day to 0.091 ; and on the twelfth day to 0.112: so that the quantity was nearly doubled in the short space of twelve days. - Lond. Med. Gaz. vol. ii. p. 830 .

$\$$ Pract. Observ. on the Colch. Aut. by Mr. Haden, Jun., p. 8. 
this form it is continued for weeks together, other opening medicines, such as jalap, being added to it as occasion may require.*

Dr. Bardsley $\uparrow$ has employed this remedy in the manner pointed out by Mr. Haden, but with very different results, and the reviewer $\ddagger$ of Mr. Haden's work equally agrees with Dr. Bardsley in depending on the early use of the lancet. Colchicum combined with saline diaphoretics, is nevertheless extremely useful in subduing inflammatory rheumatic fever, and other complaints of a decided increased action.

The preparations of colchicum are sometimes employed in consumption, water in the chest, inflammation of the larynx, and combined with purgatives in inflammation of the air-vessels of the lungs; but there is always a degree of uncertainty in their operation $\$$.

The British Colleges of Physicians direct a vinegar, oxymel, syrup, wine, and tincture.

$$
\begin{gathered}
\text { vinegar of colchicum } \| . \\
\text { Take of Fresh Colchicum bulb, sliced, one ounce; } \\
\text { Distilled vinegar } \ldots \ldots \ldots \ldots \text { one pint; } \\
\text { Proof spirit ........... one ounce. }
\end{gathered}
$$

Macerate the colchicum bulb with the vinegar in a covered vessel for twenty-four hours; then express and set the liquor aside that the feculencies may subside; lastly, add the spirit to the clear liquor.

Employed chiefly in dropsies of the abdomen and chest. Half a drachm to a drachm, in any bland fluid, every four or six hours.

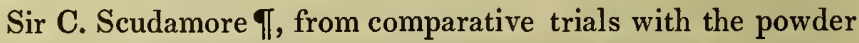
of the root, the tincture, and the acetous preparation, gives preference to the latter, on account of its remarkable mildness. By joining it with the sulphate of magnesia he found it certain in its operation on the bowels**.

* Mr. Haden, Jun., Lib. cit. p. 17.

+ Dr. Bardsley, Lib. cit. p. 117.

₹ Edinb. Med. and Surg. Journ. vol. xvii. p. 452.

\$ Dr. Murray's Syst. Mat. Med. and Pharm. 6th edit. 1832, p. 297.

II Acetum Colchici._Pharm. Lond. et Dubl.

IT Observ. Use Colch. Autumn. in Gout, 1825, p. 22.

** Treatise on Gout and Rheumatism, 2d edit. 1817, p. 185. 


\section{OXYMEL OF COLCHICUM*}

Take of Fresh Colchicum bulb, sliced, one ounce;

Distilled vinegar ......... one pint;

Clarified honey ........... two pints.

Digest the bulb with the vinegar in a glass vessel for two days; then to the liquor strongly expressed from the root add the honey; and lastly, boil down the mixture to the consistence of a syrup, frequently stirring it during the boiling with a wooden spoon.

Given in dropsies and humoral asthma, but it is very uncertain in its operation. A drachm, gradually increased to an ounce, in any bland fluid, twice or thrice a day.

$$
\text { SYRUP OF COLCHICUM } \uparrow \text {. }
$$

Take of Fresh Colchicum bulb, sliced, one ounce;

Distilled vinegar ......... sixteen ounces;

Refined sugar .......... twenty-six ounces.

Macerate the bulb in the vinegar for two days, shaking the vessel occasionally; then express gently, strain the liquor, and add the sugar; lastly, boil a little, so as to form a syrup.

A similar preparation to the oxymel, and used for the same disorders. The dose is from half a drachm gradually increased to four, six, or eight drachms.

TINCTURE OF COLCHICUM SEED + .

Take of Seeds of Colchicum, two ounces;

Proof spirit ..... one pint.

Macerate for fourteen days, and strain.

The tincture is the most active preparation of colchicum; proof spirit being the strongest solvent of the principles of the root; and we find, as a medicine, that it stimulates the most, and often irritates the stomach and bowels in a remarkable degree \&. The dose is from ten drops gradually increased to two drachms.

WINE OF COLCHICUM $\|$.

Take of Fresh Colchicum bulb, bruised, one ounce;

Proof spirit ........... four ounces;

Distilled water .......... eight ounces.

Macerate for fourteen days, and filter.

- Oxymel Colchici.-Pharm. Dubl.

† Syrupus Colchici Autumnalis. - Pharm. Edinb.

† Tinctura seminum colchici.-Pharm. Dubl.

§ Sir C. Scudamore's Observ. p. 33.

„I Vinum Colchici.-Pharm. Lond. 
This preparation is next in strength to the tincture. Sir C. Scudamore considers it as most deserving of preference in any case of disease in which we are desirous of obtaining the greatest share of specific agency which the colchicum possesses. It requires to be administered with care, for it is liable to affect the stomach with sickness, and the mucous membrane of the bowels with great irritation. The dose is from thirty drops to a drachm and a half, given in conjunction with magnesia in the effervescing draught, or with some bitter infusion. The petals of the flower and the seeds possess the same properties as the bulb*; hence many practitioners prefer a wine prepared from the unbruised seed.

$$
\text { WINE OF COLCHICUM SEED } † \text {. }
$$

Take of Seeds of Colchicum, two ounces :

Sherry wine ....... two pints.

Macerate for eight days, and filter.

As an external application, a few fresh bulbs, sliced, bruised, and mixed with a bread poultice, may be effectually applied to the gouty parts. This should be repeated twice or three times in twenty-four hours.

* Dr. Thompson's Dispensatory, 8th edit. p. 300.

† Dr. Thompson, Lib. cit. p. 957. 
I.I.

\section{'TUSSILAGO FARFARA. \\ Coltsfoot.}

\section{Class XIX. Syngenesia.-Order II. Polygamia Superflua.}

Nat. Ord. Compositæ.

Gen. Char. Involucre formed of a simple row of equal, linear, sub-membranous scales, tumid at the base. Receptacle naked. Flowers radiant; those of the circumference long, linear, numerous; of the disk few. Pappus simple.

Spec. Char. Scape single-flowered, imbricated with scales. Leaves cordate, angular, toothed, downy beneath.

S Y NON Y MES.

Greek..... Ви́xusov. Dioscorides.

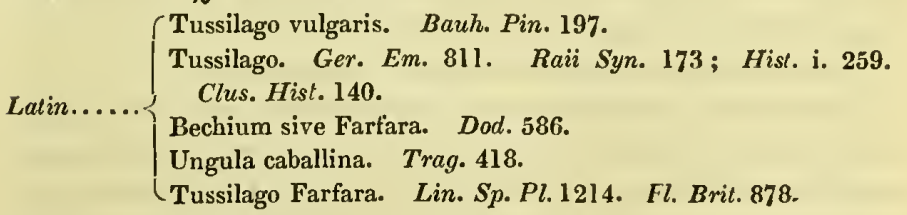

French... Tussilage; Pas d'Ane; Taconnet.

Italian.... Tossilagine; Unghia Cavallina ; Farfaro.

Spanish... Tusilago; Una de Asno.

Portuguese Tussilagem.

German ... Huflattich.

Dutch .... Hoef blad; Paarden-klaauw.

Danish.... Hof blad; Hovurt; Hestehov.

Swedish ... Hoesthof.

Polish .... Podbial.

Russ....... Dwoje Listnik. 
DEscription.-The root is perennial, very long, penetrating deep into the earth, of a whitish colour, and sending out numerous slender fibres, which creep horizontally. The scapes, which appear before the leaves, are erect, simple, one-flowered, slightly furrowed, downy, from six to ten inches in height, of a pale green varying to a reddish tinge, and clothed with numerous imbricated, lanceolate, acute scales. The leaves are all radical, large, cordate, petiolate, slightly lobed and toothed, of a bright green on the upper surface, whitish and cottony beneath. The involucre consists of a simple row of linear equal scales, erect at first, afterwards reflexed. The receptacle is naked, flat, ultimately becoming convex. The florets of the circumference are long, linear, numerous, and generally fertile ; those of the disk are few in number, mostly barren, short, tubular, with a limb divided into five acute, recurved segments. The anthers are united into a tube. The germen is obovate, with a filiform style, and two protruded linear stigmas. The fruit is oblong, compressed, crowned with a simple sessile pappus, and containing a solitary erect seed without albumen. Plate 14, fig. 2, (a) one of the female florets of the circumference; $(b)$ one of the central hermaphrodite florets ; $(c)$ the fruit*.

The Coltsfoot is a native of Europe, from Italy to Sweden. It grows in moist and clayey soils, in sterile and waste places, fallow fields, and the banks of rivers. It is the first plant that vegetates in marl or lime stone rubble, and in places where the earth from canals, roads, $\&$ c., has been thrown up. "The clayey part of the pestilential Maremmes of Tuscany, where scarcely any other plant will grow, is covered with Coltsfoot." $\uparrow$ It flowers in March and April, and produces its leaves in May.

The generic name is derived from tussis, a cough, and ago, to drive away, in allusion to the pectoral properties of the flowers, and the term $B_{1} \chi^{l o v}$, by which it is mentioned by Dioscorides, was formed from $\beta_{\eta}^{\prime} \xi$, a cough. The specific name is an alteration of Farfarus, applied by the Greeks to the white poplar, the leaves of which bear some resemblance to the Coltsfoot. Some of the ancient botanists designated this plant by the whimsical name of filius ante patrem, because the flowers appear before the

* Commonly called secd.

+ Loudon's Encycloperdia of Plants, p. 704. 
leaves. It is sometimes called provincially Foal's-foot, Horsehoof, and Bull's-foot.

The genus includes a few species, chiefly natives of Europe. The sweet-scented (Tussilago fragans) is much valued in gardens, both for the agreeable odour of its flowers and their early appearance. It is a denizen of Italy and Barbary. The butterbur, formerly considered a species of Tussilago, according to Desfontaines and others, constitutes a distinct genus, and is called Petasites vulgaris. It is remarkable for its large creeping roots, immense leaves, and fine thyrse of white or purplishcoloured flowers, appearing before the leaves, and forming an elegant appearance in the beginning of spring on the banks of rivers and in wet meadows. It was formerly called Pestilentwort, from its supposed efficacy in the plague.

This plant is eaten by goats and sheep, and sometimes by cows, but horses and swine refuse it.

Qualimies and general Uses.-Injurious as Coltsfoot often is to the farmer, it is not without use in preparing the barren and clayey soils, in which it springs up so plentifully, for the reception of other plants*. The leaves are often smoked for tobacco, and the downy substance that clothes their under surface, after being dipped in a solution of saltpetre and dried in the sun, forms excellent tinder. Both leaves and flowers have been employed medicinally; the former should be collected and dried as soon as they are quite expanded, and before they have attained their full size. "The dried plant is inodorous, mucilaginous, rather disagreeably bitter and styptic to the taste. The latter quality, together with the black colour produced in the infusion by sulphate of iron, indicate an astringent principle; but further than this its constituent principles are unknown." + Water extracts the mucilage of the leaves, and a peculiar odour is evolved during the process of boiling.

Medical Properties and Uses. - From the very infancy of

* The pappus or seed-down is a beautiful provision for the dissemination of the plant, and there appears to be some peculiar conservative property in the coats of the seed, or a vitality in the sced itself, as it frequently vegetates in soil that has been recently thrown up from deep pits where it must have been buried for ages.

+ Flore Medicale, tom. vi. p 234 
the healing art, Coltsfoot has been esteemed useful in coughs and other pectoral affections. Hippocrates * recommended the root mixed with honey in ulcerations of the lungs. Dioscorides $t$, Pliny + , and Galen $\S$, relate that the smoke of the leaves, received into the mouth through a funnel or reed, is efficacious in coughs and laborious breathing; and, by the testimony of Linnæus, it is to this day, in Sweden, a popular remedy for coughs. Boyle $\|$ added flowers of sulphur and powdered amber to the dried leaves for the same purpose, but the propriety of this addition is rather questionable. According to Fuller If a decoction of the leaves is a valuable medicine in scrofula; and Dr. Cullen** states that he employed it in scrofulous cases with apparent success. The expressed juice of the fresh leaves, taken to some ounces every day, in several instances, occasioned the healing up of scrofulous sores, and a strong decoction of the dried leaves seemed to answer the same purpose $+\uparrow$. Dr. Alibert, of the Hospital St. Louis, Paris, has tried it in scrofula, but with very little benefit. Dr. Percival ++ found it useful in hectic diarrhœas. The herb has been occasionally applied in form of a cataplasm to inflamed surfaces, and, parboiled in wine, it was recommended by Hippocrates as a useful application to ulcerated luxations. Its fumes have also been deemed efficacious in toothache.

The root, flowers, and leaves of Coltsfoot have been employed for medical purposes, the latter most commonly. Both the distilled water and the conserve of the flowers are said to be inert, and the syrup is thought to owe its reputation to the sugar it contains, but it is agreeable to the palate, and may be prepared like other syrups. Of the expressed juice of the fiesh leaves from one to four ounces may be administered daily. The de-

- Lib. de Internis affectionibus, Ed. Foes. 1. 34, p. 532.

+ Lib. iii. c. 126.

$\ddagger$ Lib. xxvi. c. 6, p. 651 .

§ Simpl. lib. vi. p. 414.

\|I De Util. Phil. Nat.

T. Medicina Gymnastica, p. 87.

** Mat. Med. vol. ii. p. 460.

$+\uparrow$ Loco cit.

拉 Essays Med. and Exper. vol. ii. p. 224. 
coction has been found of great service in coughs and other pulmonary complaints*.

\section{DECOCTION OF COLTSFOOT.}

Take of dried leaves of Coltsfoot, one ounce :

Water............... one quart.

To be boiled down to one pint, and sweetened with sugar or honey. Or twice the quantity of the fresh leaves may be used, and the decoction added to veal or mutton broth.

The dose is from two to four ounces, several times a day.

COMPOUND INFUSION OF COLTSFOOT.

Take of dried leaves of Coltsfoot, ........ one ounce;

$\left.\begin{array}{l}\text { Liquorice root, sliced, } \\ \text { Angelica root, pounded, }\end{array}\right\}$ of each half an ounce;

Boiling water ............. one quart.

Infuse them for two hours, then pour off the liquor.

For troublesome coughs, an ounce of paregoric elixir may be added to this infusion, of which a wine-glassful may be taken at a dose.

The leaves of Coltsfoot dried, are commonly used as a specics of tobacco, and are smoked with advantage by asthmatic and plithisical persons. This is a principal ingredient in all the lierb tobaccos, and constitutes the chief part of their value. The best of these mixtures consists of the following plants, the proportions of which may be altered according to circumstances.

Take of coltsfoot leaves, dried....... one pound ;

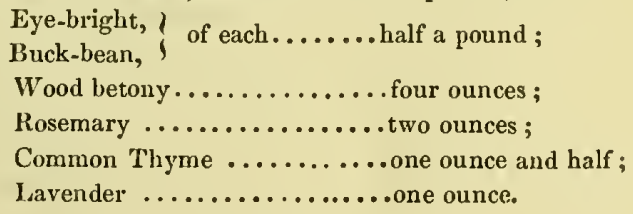

To these may be added, with great advantage,

Flowers of Coltsfoot ............. two ounces,

Rosemary ......................

- Dr. Paris informs us that the nostrum sold under the name of Essence of Coltsfoot, consists of equal parts of Balsam of Tolu and Compound Tincture of Benzoin, to which is added doulle the quantity of Spirits of Wine. We need scarcely add that this is a most injurious compound. 
Some add rose-leaves and chamomile flowers, but the form just given will be found the most agreeable, and is sufficiently salutary. The herbs should be gathered in their season, and dried in the shade, then rubbed to a coarse powder between the hands. Those who prefer a mild tobacco, may increase the quantity of Coltsfoot, which some prefer in the proportion of one half to the whole quantity, and where this is used as a remedy for asthma or consumptive cough, the Coltsfoot ought to occupy at the least that proportion*.

* Brit. Dom. Herbal, p. 94. 


\section{AQUILEGIA VULGARIS.}

\section{Common Columbine.}

\section{Class XIII. Polyandila.-Order II. Pentagynia.}

Nat. Ord. Ranuneulacel.

Gen. Char. Calyx of five, coloured, deciduous sepals. Petals five, terminating below in a long, nectareous, horn-shaped spur. Capsules five, distinct.

Spec. Char. Spur incurred. Capsules hairy. Stem leafy, many-flowered. Leares nearly smooth. Styles not longer than the stamens.

\section{S Y N O N Y E S.}

(Aquilegia sylvestris. Bauh. Pin. 144.

Latin.... $\left\{\begin{array}{l}\text { Aquilegia cœrulea. Ger. Em. } 1093 . \\ \text { Aquileia. Dod. 181: } \\ \text { Aquilina. Lob. Obs. 440. } \\ \text { Aquilegia vulgaris. Lir. Sp. Pl. } 752 .\end{array}\right.$

French .... Ancolie; Ancolie vulgaire; Colombine; Aiglantine.

Italian.... Aquilegia; Aquileia.

Spanish.... Paxarilla ; Aquilena.

German.... Akelei ; Ackeley.

Dutch..... Wilde Aguieley; Akkeley.

Swedish.... Orlik.

Polish .... Aker-lilia.

Russ....... Kolokoltschiki.

Japanese . . Odamaki.

Deseription.- The root is tuberous, branehed, fibrous, and of a whitish eolour. The stem is ereet, eylindrieal, branehed, leafy, slightly hairy, of a reddish tinge at the base, and rising to the height of two or three fcet. The radieal leaves are large, thrice ternate, with rounded three-lobed, erenatcd leaflets, and stand on very long footstalks; those of the stem gradually de- 
crease in size towards the summit, so that the uppermost are small, nearly sessile, and simply ternate, or three-lobed; they are all of a deep green above, and glaucous beneath. The flowers are terminal, pendent, and supported on long axillary peduncles. The calyx resembles a corolla; it consists of five coloured, ovate, equal, spreading sepals. The five petals are of a purplish-blue colour, like the sepals, and alternate with them, tubular, dilated upwards, their lower portion extended into a long nectareous spur, which is somewhat incurved and obtuse at the end. The stamens are from thirty to forty in number, with subulate filaments, the inner abortive, dilated, and clasping the germens ; anthers cordate, erect. The germens are five, superior, oblong, each tapering into an awl-shaped, erect style, about as long as the stamens, and terminated by a simple stigma. The fruit consists of five capsules or follicles, nearly cylindrical, straight, pointed, one-celled, one-valved, and many-seeded. The seeds are oval, smooth, dark, and shining, and attached to both edges of the suture of each follicle. Plate 13, fig. 3, (a) stamens and pistils; $(b)$ a petal with its spur; $(c)$ the pistils, the germens of which are surrounded with ten scales; $(d)$ the fruit, consisting of five capsules or follicles united at the base.

This plant is found in meadows, woods, and coppices in several parts of England, but it can scarcely be reckoned an indigenous plant, having escaped from gardens, where it is very generally cultivated. A common near Skegby, in Nottinghamshire, Langwith Woods, in Derbyshire, and Ditchling Common, Sussex, are mentioned as some of its localities. It flowers in June.

The generic name is derived from aquila, an eagle, in reference to the spurs of the petals, which were thought to resemble the claws of that bird. The common English name suggests the idea of the more gentle dove. There is some doubt as to whether the Columbine was familiar to the ancients: Caspar Bauhin considers it the $1 \alpha \sigma \omega \omega r y$ of Theophrastus, and the $1 \sigma 0 \pi v$ pov of Dioscorides.

The genus Aquilegia is not very numerous, but most of the species are pretty and vivacious, especially the Alpine Columbine (A. Alpina). The plant before us is an old inhabitant of the flower-garden, and there are many varieties with violet, purple, red, flesh-coloured, and white flowers, but no art can change these tints to yellow. 
Goats, and sometimes sheep, will eat this plant ; other animals refuse it. Bees are very fond of the petals, (nectaries of Linnæus,) the tube of which they pierce to obtain the honied juice.

Qualities.-The odour of the recent plant is weak, ungrateful, and rather stupifying; the taste bitter and nauseous. The bruised seeds are somewhat mucilaginous, with a slight bitterness and acrimony, the odour strong, and so tenacious that it is with great difficulty removed from the mortar in which they are pounded. The syrup prepared with the flowers is said to be a better test of acids and alkalies than that of violets. According to Geoffroy*, the seeds contain a large quantity of oil and ammoniacal salt.

With regard to the poisonous effects of this plant, Linnæus + states that children have lost their lives by taking an over-dose, administered as a medicine by ignorant persons. It certainly belongs to a suspicious natural order.

Medical Properties and Uses - The medical properties of Columbine have been greatly extolled at various times. The root, the leaves, the seeds, and the flowers, have been esteemed aperitive, diuretic, diaphoretic, and antiscorbutic. Simon Pauli $\$$ asserts that children attacked with measles and small-pox have been recovered as if from the dead, by taking half a drachm of the seeds in powder, or twice that quantity in emulsion. Scopolis aserts that he has found them extremely useful in facilitating the eruption of the pustules in those diseases, and Linnæus inclines to the same opinion. Tragus $\|$ and Matthiolus ordered the pulverized seeds in the dose of a drachm mixed with saffron, to be taken in a glass of wine, as a remedy for jaundice. The former also recommends the root in colic. Camerarius states that in Spain they use the root in calculous and gravelly disorders; Clusius recommended it in difficult labour, and Ettmuller in scurvy. Tournefort 9 lauded a tincture of the flowers made with spirit of wine, and mixed with equal parts of tincture of lac and mastic, as very efficacious in ulcera-

* Mat. Med. vol. iii. p. 110.

† Flora Suecica, p. 187.

† Quadrip. Bot. p. 23.

\$ Flora Carn. ed. 1, p. 551.

\| Kreutterbuch, p. 44.

- Hist. des Plantes de Paris, vol. ii. p. 264. 
tions of the mouth and scorbutic affections of the gums. Eysel ** considers the expressed juice inferior to no other remedy as an antiscorbutic ; he likewise extols it in hæmorrhages of the uterus, and hectic perspirations arising from a scorbutic taint. Ray $\phi$ states that a decoction of the leaves makes an excellent gargle in inflammation of the throat and trachea.

Notwithstanding the positive statements of the old writers respecting the diuretic, sudorific, and deobstruent properties of Columbine, it is very seldom employed in our days. Experiments are wanting to ascertain its real character and its mode of action upon the system, we shall not therefore recommend it as a medicine, but merely subjoin a formula for the preparation of the syrup, which is said to be a better test for acids and alkalies than that of violets.

SYRUP OF COLUMBINE.

Take of fresh flowers of Columbine, two pounds;

Boiling water.......... four pounds.

After digesting them for ten hours, strain the liquor; then repeat the process twice, with a like quantity of recent flowers.

Add to the third straining,

White sugar, four pounds.

Clarify, and boil gently to the consistence of a syrup. In order to obtain a fine blue colour, it is necessary that the petals be not bruised, and that the infusion be not protracted too long.

* Diss. de Aquilegiâ antiscorbuticorum asylo.-Erford, 1716.

$\dagger$ Hist. Plant. tom. i. p. 707. 


\section{LIII.}

\section{SYMPHYTUM OFFICINALE.}

\section{Common Comfrey.}

\section{Class V. Pentandria._-Order I. Monogynia.}

Nat. Ord. Boraginees.

Gen. Char. Calyx five-cleft. Corolla cylindrical, inflated upwards; throat closed with five subulate scales conniving into a cone. Stigma simple. Seed gibbous.

Spec. Char. Stem winged above. Leaves ovate-lanceolate, very decurrent at the base.

\section{SY N ON YMES.}

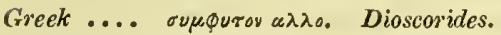

Latin ..... $\left\{\begin{array}{l}\text { Symphytum consolida major, Baul. Pin. } 259 . \\ \text { Consolida major fiore purpureo. Ger. Em. } 806 . \\ \text { Symphytum magnum. Raii Syn. } 230 . \\ \text { Symphytum Consolida major, flore pallide luteo, quæ femina. } \\ \text { Tourn. Paris. } 306 . \\ \text { Symphytum officinale. Lin. Sp. Pl. 195. Eng. Bot. } 1.817 .\end{array}\right.$

French.... Consoude; Grande Consoude; Langue de Vache.

Italian ... Consolida maggiore; Sinfito.

Spanish.... Consuelda ; Consolida mayor.

Portuguese. Consolda major.

German... Beinwell; Wallwurz; Schwarzwurz.

Dutch .... Smeerwurtel; Heelwortel ; Waalwurtel.

Danish ... Kul sukerod.

Bohemian . Kostiwal; Swalujk.

Swedish.... Walloöst.

Polish..... Zywokost.

Russ. .... Solnoi koren.

Descrirtion. - The root is perennial, thiek, tapering, somewhat branched, fibrous, of a brownish black externally, white within. The stems are succulent, ereet, branched, rough with 
strong hairs, somewhat angular, slightly membranous at the angles, and rising to the height of two feet. The leaves are alternate, large, attenuate, acute, of a deep green colour, rough and fringed with short hairs ; the lower ones are ovate and petiolate; the upper nearly sessile, ovate-lanceolate and very decurrent, so as to form winged appendages to the stem. The flowers are disposed in a short, drooping raceme, somewhat incurved towards the summit, and generally turned towards the same side; they vary from a yellowisl white to a purplish or reddish hue. 'The calyx is divided into five lanceolate segments, which are rough, erect, pointed, and about the length of the tube of the corolla. The corolla is cylindrical, swollen upwards, with a short tube, and divided at the limb into five short recurved segments, the throat closed with five subulate scales converging into a cone. The stamens are five, with short filaments inserted into the corolla, terminated by yellow, erect, sagittate anthers concealed by the scales. The germen is four-parted, with a style longer than the corolla, and a small obtuse stigma. The fruit consists of four angular, dark, shining achenia, or small nuts, situated in the bottom of the persistent calyx. Plate 10, fig. 3, (a) calyx and pistil; (b) the corolla opened to shew the stamens and scales; $(c)$ the fruit.

This plant is frequently met with by the banks of rivers, ditches, and watery places, flowering in May and June.

The common Comfrey is generally supposed to be the plant described by Dioscorides under the name of $\sigma \nu \mu \phi v \tau \nu^{*}$, derived from oup $\psi \omega \omega$, to unite, on account of the consolidating and vulnerary qualities which were ever attributed to this plant; hence also the Latin, consolida,_symphytum, and the French, consoude, and other synonymes. The term Comfrey was probably derived from the old French word Comfrie, or Consyre, having the same meaning as the foregoing. In rural dialects it has also the names of Consound, Knit-back, Bone-set, and Blackwort.

The plants contained in this genus are large and coarse, but showy and well adapted for shrubberies. They are mostly propagated by dividing the roots, which will grow in almost any soil or situation. There is one other British species, the tuber-

* Quod carnes dum coquuntur agglutinat additum.--Diosc, lib. iv. c. 9, p. 249, et Plin. lib. xxvii. c. 6, p. 670. 
ous-rooted Comfrey, (Symphytum tuberosum,) with a simple stem and leaves very slightly decurrent. It grows in shady woods and by the banks of rivers in Scotland, especially in the Lowlands. The common Comfrey is eaten by sheep and cows, but refused by other animals.

Qualities and general Uses.-The leaves of this plant were formerly used to impart a flavour to cakes and panada, and the young shoots are said to be good and nutritious food. A strong decoction of the plant will dye wool of a brown colour. The root has been applied to several important purposes. The beautiful crimson colour obtained from gum-lac is extracted by means of a decoction of this root, and the natives of Angora prepare from it a kind of glue, which they use to spin the celebrated fleeces of their country into fine yarn, from which camblets and shawls are manufactured. It has also been employed for correcting the brittleness of flax and the roughness of wool. Tabernamontan, a German writer, highly extols its superiority in tanning leather. He boiled ten pounds of the root in four gallons of water till one-half was consumed; with this decoction he repeatedly dressed the leather, which, thus prepared, became not only more durable than by any other method, but it uniformly remained pliable and elastic. Another experimentalist, after making a strong infusion of the root, allowed it to stand for several days, and when the woody and fibrous parts had subsided, poured off the liquor, and by dropping in to it diluted oil of vitriol, he precipitated the mucilaginous part, which was again filtered and rendered serviceable for tanning, by neutralizing its acidity with a ley formed of common potash.

The leaves and flowers are rarely employed in medicine. The root, which is most frequently used, is inodorous, insipid, sweetish, viscid, and glutinous. It contains an abundance of mucilage, more tenacious than that of marsh-mallow, accompanied with gallic acid in'sufficient quantity to render the aqueous decoction quite black by the addition of sulphate of iron.

Medical Properties and Uses.-Comfrey was highly extolled by the ancients for its supposed vulnerary properties; it was also esteemed emollient, agglutinant, and astringent, and recommended not only in spitting of blood, uterine hæmorrhages, consumption, coughs, inflammation of the kidneys and urinary organs, but as very potent in effecting the re-union of wounds: 
the consolidation of fractures, and the cure of luxations and hernia. Thus, according to Gerard *, "the roots of Comfrey stamped, and the iuice drunke with wine, helpeth those that spit bloud, and healeth all inward wounds and burstings. The same bruised and layd to in a manner of a plaister doth heale all fresh and green wounds, and are so glutinatiue that it will soder or glew together meat that is chopt in pieces, seething in a pot and make it in one lump. The roots boiled and drunke do clense the brest from flegme, and cure the griefes of the lungs, especially if they be confect with sugar and syrup; it prevaileth much against ruptures or burstings." Dioscorides used it in hæmoptysis, and Pfann $\uparrow$ states that a small quantity of the powdered root snuffed up the nostrils will stop bleeding at the nose. Simon Pauli + recommended the application of it to fractured bones, and Houston, in hernia. Tachenius $\S$ advises the bruised root to be applied in the form of a cataplasm in gout, and a case is mentioned by Camerarius $\|$ in which the pain was removed by this application, but an eruption of pustules was the consequence, which at length spread over the whole body.

All that can be expected from this plant must result from its emollient and demulcent qualities, and the mucilage of the root being combined with gallic acid is undoubtedly of service in chronic catarrhal affections, accompanied with irritation; it is also useful in dysentery, diarrhœa, fluor albus, \&c. To prepare the mucilage the sliced root should be put into cold water, care being taken to prevent the liquor from boiling, which causes great clots to be formed; and it should not be performed in an iron vessel. When the mucilage is dissolved it should be removed from the fire, and after being sweetened with honey or " sugar, it may be taken a glassful at a time in the above-mentioned complaints. It was used externally by Ettmuller and others as an application to wounds of the nerves, tendons, and arteries; especially those which result from the operation of bleeding, but is seldom or never used for those purposes in the present day. Several syrups, conserves, and potions, have also

* Herbal, or General Historie of Plants, ed. lyy Johnson, fol. 1633, p. 807.

† In. Samml. Merkro. Fälle, p. 249.

* Quadrip. p. 301, seq.

$\$$ De Morborum principe, p. 199 .

II In Mise. Nat. Cinr. Dec. 3, Anu. 5, 6. Olss. 16, p. 45. 
been recommended. The plasters into which it entered are now generally abandoned. The syrup extolled by the celebrated Boyle in spitting of blood is thus prepared.

SYRUP OF COMFREY.

Take of Comfrey-root ....... six ounces;

Plantain-leaves ...... three ounces.

Bruise them together in a marble mortar, and express the juice; then, after clearing the liquid, add of

White sugar ........ an equal quantity.

Boil to the consistence of a syrup.

Two or three spoonsful may be taken at a dose. If for coughs, a small quantity of liquorice-root may be added before the sugar.

ASTRINGENT DRINK.

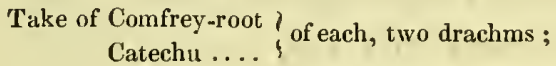

Water............ one pint.

Reduce by boiling to six ounces, then add

Syrup of Clove-pink .. one ounce;

Cinnamon water .... half an ounce.

A desert spoonful to be taken every hour in chronic diarrhœa and dysentery. 


\section{I.IV.}

\section{CORIANDRUM SA'TIVUM.}

Common Coriander.

\section{Class V. Pentandria,-Order II. Digynia.}

Nat. Ord. Umbellifere.

Gen. Char. Calyx of five teeth. Petals obcordate, with an inflexed point; the outer ones radiant, bifid. Fruit globose. Carpels with five, primary, depressed, wavy ridges; the four secondary ridges prominent and carinated. Channels without vittw, the inner face of the carpel having two vittæ. General involucre none; partial on one side.

Spec. Char. Lower leaves bipinnate; leaflets wedgeshaped.

S Y N O N Y M S.

Greek ..... xoprov; xopravvov.

Latin.... $\left\{\begin{array}{l}\text { Coriandrum majus. Bauh. Pin. } 158 . \\ \text { Coriandrum. Ger. Em. 1012. Raii Hist. 270. Syn. } 221 . \\ \text { Coriannon sive Coriandrum. Fuchs. 345. } \\ \text { Coriandrum vulgare. Park. Theatr. 918. } \\ \text { Coriandrum sativum. Lin. Sp. Pl.367. Eng. Bot. t. } 67 .\end{array}\right.$

French.... Coriandre.

Italian... Coriandro; Coriandolo.

Spanish ... Cilantro; Culantro.

Portuguese Coentro.

German .. Koriander ; Wanzendille.

Dutch .... Koriander.

Swedish .. Coriander.

Polish .... Koryander; Koriandrze.

Russ. .... Koriander.

Bengalee .. Dunya.

Sanscrit... Dhanyaka.

Tamool .. Cottamillie.

Hebrew ... Ghad. 
Description.-The root is annual, tapering, slender, somewhat branched, whitish, and furnished with a few fibres. The stems are erect, branched, leafy, cylindrical, striated, rather glaucous, and about two feet in height. The lower leaves are bipinnate, with pinnatifid, broad, wedge-shaped, toothed segments; the upper tripartite, with narrow, linear, acute segments. The flowers are disposed in terminal umbels of from five to eight rays, which in general have no involucre at the base. The umbellules are more numerous, and are commonly furnished with an involucre of three linear-lanceolate leaves, placed laterally. The calyx consists of five unequal acute teeth. The petals are five, white or tinged with purple, obcordate, and inflexed at the point; the innermost nearly equal; the outer large, radiant, and bifid. The five stamens have thread-shaped filaments, and roundish yellow anthers. The germen is inferior, globose, supporting two, short, spreading styles, terminated by simple obtuse stigmas. The fruit consists of two hemispherical carpels, each furnished with a projecting margin on its inner and flat side, which combines with the opposite one, thus forming a complete globe, which at maturity is traversed by ten obscure ridges. The seed is concave in front, and covered with a loose mcmbrane. Plate 13, fig. 4, (a) lower leaf; $(b)$ floret of the circumference of the umbel; (c) floret of the centre; $(d)$ fruit.

The native country of the Coriander has not been correctly. ascertained; in all probability it came originally from the East, whence it migrated into Italy and Greece, and having been cultivated in England for medicinal and culinary purposes, has escaped into fields and waste places. It has long been cultivated in Essex and about Ipswich for the sake of its seeds. It flowers in June, and the seeds are fully ripe in August.

Several writers have imagined that this is the roplov of Dioscorides, the ropravroy of Theophrastus, and the Coriandrum of Pliny, but their identity is not fully established. The generic name Coriandrum is derived from $x_{0} \mathrm{f} b, a b u g$, in allusion to the fetid smell of the bruised foliage.

Qualities and general Uses.-Although the leaves in their recent state have a strong disagreeable smell, yet when dried 
they are pleasant and aromatic. In some countries they are eaten in soups and salads, and the inhabitants of Peru are excessively fond of the flavour. Alpinus * states that the Egyptians use the herb freely in soups; it is eaten also in Spain and esteemed cordial, but Hoffman + relates, on the authority of a monk, instances of fatuity produced by it. Murray $\ddagger$ asks whether the virus is dispersed by boiling. Dioscorides likewise attributed deleterious properties to the seed, but Dr. Withering has known six drachms taken at once without any remarkable effect.

Coriander seeds enter into the composition of several liquors, and form an ingredient in curry powder. When incrusted with sugar, they are sold by the confectioners under the name of coriander comfits.

The virtues of the seeds are completely extracted by rectified spirit, but only partially by water. In distillation with water they yield a yellowish essential oil, of a very aromatic and powerful odour.

Cucrure._- The seeds are sown on a rich, light soil in September; twenty pounds will sow an acre. When the plants come up, thin them to six or eight inches' distance every way, and next spring stir the soil with a pronged hoe. In August the seed will be ripe, and if care be not used, the greater part of it will be lost. 'To prevent this, women and children are employed to cut, plant by plant, and to put it immediately into cloths, in which it is carried to some convenient part of the field, and then threshed upon a sail cloth. A few strokes of the flail get the seeds clean out, and the threshers are ready for another bundle in a few minutes, The produce is from 10 to $14 \mathrm{cwt}$. per acre." $\$$

Medical Properties and Uses.-The energetic qualities of this plant led the ancient physicians to consider it very poisonous ; the juice of the leaves they considered nearly as deleterious as that of hemlock. Gerard, who probably derived his

* De Plant. Egypt. p. 131.

+ Med. Off. p. 241.

¥ App. Med. vol. i. p. 406.

$\S$ Miller's Dict. by Don. 
information from Avicenna*, tells us that "the juice of the greene Coriander leaues, taken in the quantitie of foure dragmes, killeth and poisoneth the body." Matthiolus and Tragus advisc it never to be used without previous maceration in vinegar. Gilibert states that he experienced head-ache, nausea, and cardialgia, from the emanations of the recent herb. On the other hand, Alpinus t, J. Bauhin, Zwelfer, Lobel, and others, deny that it possesses any noxious qualities; and they instance the daily use of it among the Egyptians, Spaniards, and Dutch, who mix it with their food and drink. It would be unjust to accuse the former party with falsehood, as the state of the herb, the mode of cooking it, and not less the power of habit, may have a great influence on the effects produced in different individuals; but the assertion of Dioscorides ${ }_{+}^{+}$, as to the hurtful consequences of taking the seeds, we know to be erroneous.

The seeds have been long known as carminative, stomachic, and diaphoretic, and successfully employed in debility of the stomach and intestinal canal, and in flatulence. Terzagus commended an infusion of half an ounce of the seeds in five ounces of wine, as a remedy in quartan agues, to be taken before the paroxysm. They have also been found useful in the hysterical disorders and head-ache of females, and in some cases of scrofula. Dr. Cullen esteemed the Coriander seeds as the best adjunct with which he was acquainted to prevent the griping effects of senna, and their aroma serves well to mask the nauseous taste and odour of various purgatives. The dose is from a scruple to a drachm in substance, and from a drachm to a drachm and a half in infusion. They enter into a carminative water, or rather spirit, with other aromatic seeds $\S,-$ a simple distilled water,-and form one of the principal ingredients in the compound called honey-water.

* Quum ex succo bibitur circiter. unc. iiij.interficit, quoniam facit hominem possidere tristitiam, et syncopim, et non oportet universalitèr, ut de eo multum sumatur.-Canon Medicina, vol. i. p. 294.

+ See the work already quoted.

¥ Si largius sumptum fuerit semen, mentem non sine periculo, e suâ sede et statu demovet.-Alexipharm. c. 9.

$\$$ Viz. Seeds of Fennel, Carrot, Anise, Caraway, and Dill; these are digested for some days in brandy and then sweetened with sugar. 


$$
\text { HONEY-WATER *. }
$$

Take of Coriander seeds

Lemon-peel, fresh)

Nutmeg .......

Storax.

Benzoin ........

Vanilla

Alcohol eight ounces ;

of each .... half an ounce;

After infusing them for twenty-four hours, distil, and add, if it be thought requisite, a small quantity of essence of amber and of musk.

It is reckoned cephalic, nervine, cordial, paregoric, and cosmetic. The dose about half an ounce.

- Aqua mellis odorata regia. 


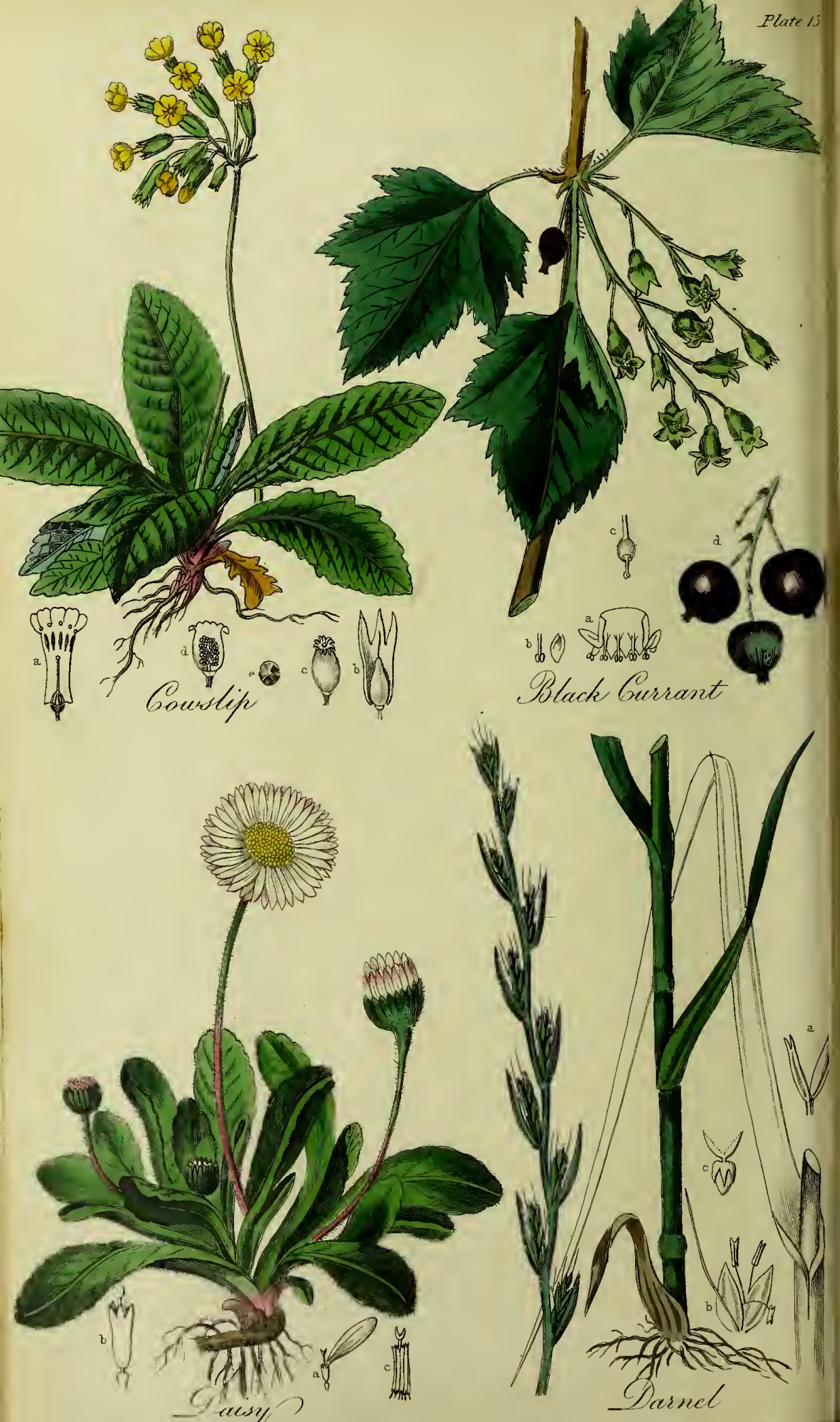




\section{LV.}

\section{PRIMULA VERIS.}

\section{Cowslip.}

\section{Class V. Pentandria.-Order I. Monogynia.}

\section{Nat. Ord. Primulacer.}

Gen. Char. Calyx inferior, tubular, fire-toothed. Corolla salver-shaped; tube cylindrical; mouth open. Capsule one-celled, opening with ten teeth.

Spec. Char. Leaves toothed, rugose, contracted below the middle. Scape umbellate. Limb of the corolla concave.

S Y NON Y MES.

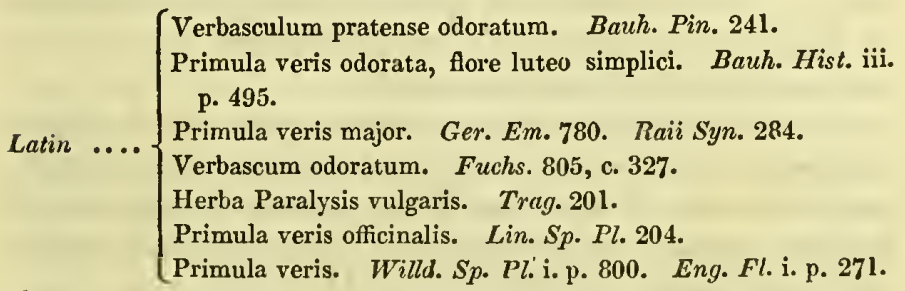

French.... Primevère; Primevère officinale; Primerolle ; Coucou.

Italian.... Primavera; Primola.

Spanish ... Primavera; Primula; Yerba de San Pablo.

Portuguese. Primavera.

German .. Schlüsselblume.

Dutch .... Sleutelbloem; Bak-kruid.

Danish.... Oxedrif.

Swedish .. Oxellogg; Orlagga.

Polish .... Bukwica Biala.

Russ. .... Bukwiza.

Description.-The roots are perennial, consisting of a fleshy rhizoma beset with several small tubercles furnished with numerous long, nearly simple fibres. The leaves proceed immediately from the root; they are ovate-oblong, wrinkled, toothed, obtuse, 
more or less pubescent, of a bright green colour above, lighter beneath, and tapering into a petiole at the base. From the middle of the leaves rise one or two upright scapes, naked, cylindrical, somewhat pubescent, about four or five inches in height, terminated by an umbel of sweet-smelling flowers, which are pedicellate, drooping, and furnished with a short subulate bractea at the base of each pedicel. The calyx is of a pale yellowish-green colour, permanent, tubular, with five angles and five short and obtuse teeth. The tube of the corolla is as long as the calyx; the limb concave, with five short lobes of a yellow colour, and marked near the orifice, which is pervious, with five orange-coloured spots*. The five stamens have very short filaments, and erect acute anthers included in the tube. The germen is globose, surmounted by a filiform style and a globose stigma. The capsule is glabrous, ovate-oblong, one-celled, opening at the top with ten acuteteeth. The seeds are numerous, brown, wrinkled, attached to a free central placenta. Plate 15, fig. 1, (a) corolla opened to show the pistil and stamens; (b) the capsule inclosed in the calyx ; $(c)$ the capsule as' it opens at maturity; $(d)$ the same cut perpendicularly to show the central placenta to which the seeds are attached; $(e)$ seed magnified.

This favourite flower of spring greets the eye with its elegant blossoms in almost every meadow, pasture, and copse throughout the months of April and May. Though so frequent in England, especially in a clayey soil, it is very rare in Scotland, and is only found about Edinburgh and Glasgow.

The generic name is very appropriately derived from primus, first, on account of the early appearance of the flowers. Cowslip, curlippe in Saxon, probably owes its name to its growing in pastures where it often meets the cow's lip + .

Thus, in "Pan's Anniversary,"

\section{"Strew, strew the glad and smiling ground}

With every flower, yet not confound.

The primrose drop,-

Bright days-eyes, and the lips of cows." -Ben Jonson.

* The corolla dried either with or without heat, invariably changes to green.

† It has also been called Paigles and Palsey-wort, the latter being a synonyme of Herba Paralysis, in allusion to its medicinal qualities. 
The fairy's description of the cowslip must not be omitted. When talking of lier queen, she says :-

"The cowslips tall her pensioners be,

In their gold coats spots you see,

These be rubies, fairy favours."

The "dainty Ariel" sings :-

"Where the bee sucks there suck I,

In a cowslip's bell I lie,

There I couch when owls do cry."

The other indigenous species of the genus are the Common Primrose (Primula vulgaris), the Bird's-eye Primrose (Primula farinosa), a beautiful plant with light purple flowers gemmed with a yellow eye, and leaves sprinkled with a fine powdery substance, having a musky scent : it is almost confined to the mountainous pastures of the north of England. The Scottish Primrose (Primula Scotica) vying in beauty with the last species, and flowering in July on the sandy shores of the Orkney Islands, the north coast of Sutherland and Caithness. P. Auricula, a native of the Alpine regions of Italy and Switzerland, is a wellknown favourite of the florist.

The Oxlip* (Primula elatior) is thought to be a hybrid between the Cowslip and the Primrose, but is much less common than either : it is distinguished by its more vigorous growth, and inodorous pale yellow flowers, - the tube of the corolla much longer than the calyx, and the limb flat. Professor Henslow has seen the Primrose, Cowslip, and Oxlip produced from the same root.

Qualities and general Uses. - The flowers which are very sweet and fragrant are often used to make wine, which is flavoured like muscadel, and is very sparkling and pleasant, but considered somniferous. The leaves have- been used as salad and pot-herbs, and, in the absence of mulberry-leaves, are very useful for feeding silk-worms. In some countries an infusion of the flowers is fermented with sugar or honey, and the juice of lemons, and an acidulous vinous liquor is thus prepared,-a very grateful summer beverage. The roots are also put into casks of wine or beer to impart additional strength and flavour to those liquids.

The root in its recent state exhales a fragrant odour, resem- 
bling anise, and has a slightly astringent and bitter taste. The leaves are herbaceous and nearly scentless. The flowers impart their virtues both to water and spirit, and are used to tincture certain liquors and syrups of a fine yellow colour. Cartheuser has obtained from the flowers a fourth part of aqueous extract, and about a sixth of resinous extract *.

For medical use the flowers are directed to be freed from their calyces, dried quickly, and preserved in a dry place.

Medical Properties and Uses.-The Cowslip though once highly celebrated for its narcotic, nervine, and anodyne virtues, has for many years fallen into disrepute with the faculty, though still employed as a rustic medicine. As already mentioned, when speaking of the old name of the plant, it was thought peculiarly efficacious in paralytic affections. The distilled water of the plant, rubbed on the forehead, was reputed to disperse head-aches $\psi$. The same was affirmed of the expressed juice of the leaves and flowers, mixed with milk, and taken in the dose of one or two ounces +. Bergius recommends an infusion of the flowers in rheumatic affections, and Boerhaave $\S$ and Linnæus esteem it useful in assuaging pain and provoking sleep.

The root excites the pituitary membrane of the nose, and has been used in its powdered form as a sternutatory ; and Boerhaave affirms that the infusion of it in vinegar, introduced by aspiration into the nasal fossæ, has in some cases relieved toothache. Chomel attributes to the root the property of dissipating vertigo, hemicrania, and other nervous symptoms resulting from a suppression of the menses. The flowers are certainly indued with a gently narcotic and sedative property, and we are informed on credible authority that they will frequently, in delicate habits, relieve pain and induce sleep when other narcotics would only irritate and distress the patient.

Beside the infusion, a distilled water, a conserve, and a syrup have been severally recommended.

INFUSION OF COWSLIP.

Take of dried Cowslip flowers, half an ounce;

Boiling water ...... one pint and a half.

* Flore Med. tom. v. p. 250.

+ Matthiolus in Dioscor. p. 802.

\# Hist. Plant. tom. ii. p. 1082.

$\S$ Plant. hort. L. B. p. 281. 
Let it stand half an hour in a close vessel. Of the fresh flowers twice the above quantity must be used.

To be drunk in the same manner as tea.

COWSLIP WATER.

Take of Cowslip flowers, one part;

Water....... three parts.

Distil one part and a half.

From one to two ounces may be taken at a dose.

SYRUP OF COWSLIPS.

Take of fresh Cowslip flowers, twelye ounces ;

Boiling water ...... one pint.

Infuse for twenty-four hours and strain, then add

White sugar ....... half a pound.

Boil gently to the consistence of a syrup. 


\section{LVT.}

\section{RANUNCULUS ACRIS.}

\section{Upright Meadow Crowfoot.}

Class XIII. Polyandria.--Order III. Polygynia.

Nat. Ord. Ranunculaces.

Gen. Char. Calyx of five (rarely three) sepals. Petals five, (seldom more,) with a nectary at their base. Pericarps without awns.

Spec. Char. Calyx spreading. Peduncles rounded. Leaves palmate, tripartite; segments acute, trifid and cut; upper ones linear. Stem erect.

S Y NON Y MES.

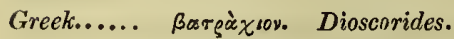

(Ranunculus pratensis erectus acris. Bauh. Pin. 178. Raii. Syn. 248.

Raunnculus surrectis cauliculis. Ger. Em.951.

Ranunculus hortensis. Dod. Pempt. 426. f. 1.

Chrysanthemum. Fuchs. Hist. 879. ic.

( Ranunculus acris. Lin. Sp. Pl. 779. Fl. Brit. 593.

French.... Renoncule acre; Grenouillette; Bouton d'or.

Italian.... Ranuncolo; Ranunculo acre

Spanish.... Ranunculo.

Portuguese Ranunculo.

German ... Scharfer Hahnenfuss; Ranunkel.

Dutch .... Veld Haanevoet; Veld Haanepoot; Boterbloem.

Danish .. Ranunkel; Smoerurt.

Swedish .. Ranunkel; Smoerblomster.

Russ .... Lutik.

Description. - The root is perennial, consisting almost entirely of long, white, slender fibres. The stems are erect, round, fistulous, branched, many-flowered, moderately leafy, beset with minute appressed hairs, and rising to the height of 
about two feet. The radical leaves are petiolate, hairy, palmated, angular, divided into three or five lobes which are variously subdivided, incised, toothed, acute, and often marked with a brown spot in the centre; the cauline leaves are similar, but less deeply divided; the uppermost are divided into three straight linear segments, or simple and linear. The flowers. are terminal, and stand on long hairy peduncles, which are cylindrical, but not furrowed. The calyx consists of five greenish-yellow, ovate, concave, spreading, somewhat villous sepals. The five petals are of a bright, glistening yellow colour, obtuse, generally notched at the summit, and having at the base a small nectary or pore covered by a scale. The stamens are very numerous, inserted upon the receptacle, with short filaments, and oblong, inclining, yellow anthers. The germens are numerous, each terminated by a very short, simple style, and a small stigma. The fruit consists of several smooth, lenticular, one-celled pericarps, (or carpels) collected into a head, and each tipped with a small mucro or point. Plate 14, fig. 4, (a) the calyx, stamens and pistils; (b) petal; (c) pericarp magnified; $(d)$ seed magnified.

This well known plant bespangles our meadows and pastures with its golden-yellow blossoms, immediately succeeding the pure white of the Cuckoo-flower, from the end of May throughout July. It is very common in almost every region except those beneath the tropics. Linnæus in his Lapland tour informs us, that when the plant is in flower, the fields of Westrobothnia are clothed with it as with a yellow mantle.

The generic name is derived from rana, a frog, because many of the species delight in damp situations where frogs abound; hence also the French provincial name, Grenouillette. This species is, in rustic phraseology, ranked with the Bulbous Crowfoot, (Ranunculus bulbosus,) and the Creeping Crowfoot, (Ranunculus repens,) under the several names of Butter-flower*, Butter-cups, King-cups, and Gold-cups. They are the "cuckoo-buds of yellow liue" in Shakspeare's immortal verse, and are probably referred to rather than the plant now called Cuckoo-flower, (Cardamine pratensis,) when we read,

* "Let weeds instead of butter-flowers appear,

And meads instead of daisies, hemlock bear."-Gay. 


\section{Darnell, and all the idle weeds."}

The genus Ranunculus is very extensive, comprehending nearly two hundred individuals, and forming the type of a natural order whose chief characteristic is the presence of an acrid principle. They are chiefly herbs with white or yellow flowers, some of them very handsome, especially the Garden-Crowfoot, (Ranunculus asiaticus, ) of which there are endless varieties. The British species are fourteen in number, and of these the bulbous and creeping kind are, together with the subject of this article, the most common; the former distinguished by its bulbiferous roots, furrowed flower-stalks, and reflexed calyx, and the latter by its creeping scions. The Celery-leaved Crowfoot ( $R$. sceleratus) is extremely poisonous and will be introduced hereafter. The Water-Crowfoot ( $R$. aquatilis) is known by its finely-divided leaves, white petals, and transversely wrinkled pericarps; it is abundant in rivers and lakes, and in some districts, particularly near the Avon, it is extensively used as food for cattle.

A variety with double flowers is cultivated in gardens under the name of Bachelor's-button, or, as the French term it, bouton d'or.

Qualities and general Uses.-Although acridity is a prominent characteristic in this plant and its congeners, it is of so volatile a nature that, as Krapf observes, simple drying, infusion in water, or boiling, are sufficient to dissipate it ; it is neither acid nor alkaline; it is increased by sugar, wine, honey, and spirit, and the mineral acids, and is only to be overcome by vegetable acids and water. Hence we are not surprised to find that the peasantry of some countries boil the herb and eat it with impunity. In its recent state it is so acrimonious, says Mr. Curtis, that by merely pulling up the plant and carrying it some little distance, considerable inflammation has been produced in the palm of the hand. According to Linnæus, sheep and goats eat it, but other animals refuse it. The popular opinion, that the yellow colour of butter is owing to this plant, needs scarcely to be refuted, as cows are never known to touch it, except when turned hungry into a meadow where it grows, and then their mouths become sore and blistered. When made into hay it loses its acrid properties, but then it seems to be too stalky and hard to afford much nourishment; if it be of any 
use it must be to correct by its warmth the insipidity of the grasses.

Professor Bigelow states, "that the acrimony of the Crowfoot, although volatile, differs from that of the Arum in not being destroyed by a moderate heat, and in being fully preserved in distillation. I have subjected various species of Ranunculus to this experiment, and always found the distilled water to possess a strong acrimony, while the decoction and portions of the plant remaining in the retort were wholly destitute of this property. The distilled water, when first taken into the stomach, excited no particular effect, but after a few seconds a sharp, stinging sensation was always produced. When swallowed, a great sense of heat took place in the stomach. I preserved some of the distilled water of the leaves for some months in a close stopped phial, during which time it retained its acrimony undiminished. In winter it froze, and on thawing had lost this property."

Poisonous Properties.-Orfila having introduced five ounces of the juice of this Ranunculus into the stomach of a small robust dog, the œsophagus being first tied, and having applied two drachms of the watery extract of the same plant to the cellular tissue of the internal part of the thigh of another strong dog, both animals died at the end of twelve and fourteen hours, without exhibiting any other phenomenon but extreme dejection. The lungs of both were engorged, reddish, and covered with several livid spots. In the first, the internal membrane of the stomach presented several spots of a bright red colour, and the limb operated on in the second animal was enormously swollen and very mucl inflamed. From these experiments he concludes that the plant acts by producing great local irritation, followed by inflammation of the parts to which it is applied, and that death takes place from the sympathetic action of the nervous system.

Krapf $\uparrow$ found, by experiments on himself, that two drops of the expressed juice of this plant produced burning pain and spasms in the gullet, and griping in the lower belly. A single flower, well pounded, had the same effect. On chewing the thickest and most succulent of the leaves, the salivary glands

* American Med. Botany. vol. iii. part i. p. 65.

+ Experimenta de nonnullorum Ranunculorum venenatâ qualitate, horum externo et interno usu. Vien, 1766. p. 101. sq. 
were strongly stimulated, his tongue was inflamed and excoriated, his teeth were set on edge and affected with shooting pains, and the gums became tender and bloody. As antidotes to this poison, he tried Castor, which was proposed by Aëtius, and the herb Balm, recommended by others of the ancients, but to no purpose. Of seventy plants, the leaves of sorrel (Rumex acetosa) only, mitigated the acrimony; next to this the juice of unripe currants appeared most beneficial; this led him to try pure vegetable acids, which together with water, as before mentioned, he found the only antidotes.

In cases of poisoning by this and other plants of the genus, the usual antiphlogistic treatment must be pursued, as already mentioned under others of the irritant poisons*.

Medical Properties and Uses.-The acrid and stimulating properties of the Ranunculi have been known ever since the time of Dioscorides $\dagger$. The leaves applied to the surface of the skin, produce pain, redness, tumefaction, elevate the epidermis, cause a discharge of serous fluid, and even considerable ulceration . The other parts of the plant, the root, the calyx, the corolla, and especially the unripe germen, give rise to the same phenomena. Consequently it has been used as a vesicatory in the same manner as cantharides, and it has this advantage, that it acts with greater rapidity and does not affect the urinary passages, but it is apt to produce great pain, swelling, deep and obstinate ulcers, and gangrene $\S$. To obviate these inconveniences, Chesnau $\|$ recommends the leaves to be pounded in a marble mortar and applied wet with the juice through a perforation of adhesive plaster, a piece not per-

* See the articles Arum, Bryony, and Colchicum.

+ "The leaves and stems are so acrid and burning that applied to the skin, they raise blisters as well as produce pain. On this account they are used to remove diseased nails and scabies, and to destroy blotches; they also disperse warts in a very short time, but they are very apt to produce ulcers. The dried powder of the root, taken into the nostrils, provokes sneezing, and applied to the teeth it often relieves pain."-Dioscor. Interp. Sarraceni, lib. ii. c. 206.

¥ Beggars and other impostors are known to use the leaves of this and other acrid species, in order to excite commiseration by the ulcers they produce.

§ Krapf loco cit. p. 105.

\|l Observ. Med. p. 11. 
forated being placed over it ; where the cuticle is thin and very sensible, it must be removed in two hours. From neglect of these precautions lie had known extensive inflammation to arise and spread over a great part of the face, neck, and breast. Thus applied, it has been used for the cure of chronic headache, hemicrania *, rheumatism of the hip-joint, gout, and other fixed pains $\psi$. In intermittent fevers, however, it has been more particularly lauded. With this view it is applied in the form of a cataplasm over the region of the stomach, or to the wrists. One of the most remarkable cases is that related by Sennert + , of an obstinate quartan fever, accompanied with great pain in the shoulders, which disappeared by the application of the meadow crowfoot to the wrists, before the access. Van Swieten $\S$ speaks of a man who several times warded off an intermittent by merely applying the plant reduced to a pulp, upon the fingers. To put us on our guard, Murrayll cites a case of a child in whom the improper use of the plant brought on dropsy of the abdomen, hydrocele, and a deep ulcer of the wrist, which injured the tendons of the flexor muscles of the fingers.

The internal use of the plant is much less common, practitioners being deterred, and very justly so, by its corrosive and deleterious character. It has however been employed in paralysis, commencing with very small doses, gradually augmented for fear of accident. Dr. Withering states that "the distilled water of the Lesser Spear-wort (Ranunculus Flammula) is an excellent emetic, and in cases of poison being swallowed, or other circumstances occurring in which it is desirable to make the patient vomit instantaneously, it is preferable to any other medicine, as it does not excite those painful contractions of the stomach which white vitriol sometimes does." If this be correct there is no reason why the distilled water of the Ranunculus acris should not be used for the same purpose.

- Pain of one half of the head.

† Vide Baglivi Opera p. 113. Störck Ann. Med. ii. 123.

† Opera, tom. i. p. 263.

§ Comment. tom. ii. p. 571.

|| Appar. Med. tom. iii. p. 81 . 


\section{LVII.}

\section{CARDAMINE PRATENSIS.}

Common Cuckoo-flower, or Ladies-smock.

Class XV. Tetradynamia.-Order II. Siliquosa.

Nat. Ord. Crucifere.

Gen. Char. Pod linear, with flat nerveless valves, generally separating elastically. Seed-stalks slender.

Spec. Char. Leaves pinnate; radical leaflets roundish, dentate; cauline ones, lanceolate, nearly entire. Style very short, straight. Stigma capitate.

\section{S X NON Y MES.}

Greek .... Ка К

(Nasturtium pratense. Bauh. Pin. 104. Trag. 83.

Iberis Fuchsii, sive nasturtium pratense sylvestrc. $J$. Bauh.

Latin ... \{ $\begin{aligned} & \text { ii. } 889 . \\ & \text { Cardamine. Ger. Em. 259. Raii Syn. } 299 .\end{aligned}$

Cardamine altera minor. Park Theatr. 826.

Flos cuculi. Dod Pempt. 582.

Cardamine pratensis. Lin. Sp. Pl.915. Fl. Brit. 699.

French .. Cardamine; Cresson des Pres; Cresson élégant; Cres-

Italian Cardamina; Cardamintura ; Nasturzio selvaggio; Crescione Italian.... pratense.

Spanish .. Cardamino de Prados.

German .. Wiesenkresse; Weisen-Schaumkraut.

Dutch .... Koekkoeks-blœm; Klein Water-kers; Water Violen.

Danish.... Engekasse; Vildkasse; Giogeblomster.

Swedish.... Engkrasse.

Polish .... Rzezucha polna.

Russian .. Lugobüi kres.

Description.-The root is perennial, whitish, firm, branched, and sends off many long, cylindrical fibres. The stem is upright, cylindrical, generally simple, smooth, and rising about 
a foot in height. The leaves are alternate, pinnate; the radical ones composed of from five to nine roundish, angular leaflets, which are gradually larger towards the summit; the leaflets of the cauline leaves are more numerous, straight, entire, lanceolate, and the uppermost even linear, the terminal one the largest. The flowers terminate the stem in loose, raceme-like corymbs. The calyx consists of four oblong, obtuse, concave, deciduous, slightly spreading sepals, two of them protuberant at the base. The four petals are much larger than the calyx; cruciform, and nearly round, with a small tooth on each claw, marked with conspicuous veins, and of a white, blueish, or pale purple colour. The stamens are tetradynamous, inserted on the-receptacle, the two shorter filaments with a nectareous gland at the base, and one between each pair of longer filaments and the calyx; the anthers are small, oblong, arcuate, acute, and erect. The germen is superior, cylindrical, linear, smooth, supporting a small, nearly sessile, obtuse, capitate stigma. The fruit is a silicle or elongated pod, linear, compressel, with two valves, which roll back in a spiral manner from the base to - the summit; and divided by a dissepiment into two cells, which contain numerous, rounded seeds, attached alternately to the placenta in a single row, by very short and slender stalks or funicles. Plate 17, fig. 3, (a) calyx, stamens and pistil somewhat magnified; (b) silique or fruit, of the natural size; (c) the same, showing its mode of dehiscence.

This pretty vivacious plant is found in moist meadows, marshes and the sides of ditches in great abundance; its blossoms first appear about Lady-day, and are very profuse towards the end of April and the beginning of May. In the woods and alpine pastures of Lapland it is everywhere obvious.

The generic name is derived from $x_{0} \delta \delta \alpha$, the heart, and $\delta \alpha \mu \alpha \omega$, to fortify, from the supposed stomachic qualities of the plant,

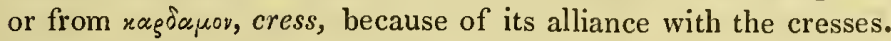
This species was named Lady's-smock*, in honour of the Virgin Mary, as it first comes into flower about Lady-day ; and as it

* " Lady-smocks all silver white,

Do paint the meadows much bedight."-Shakspeare.

"Bright crown-imperial, king's-spear, hollyhocks, Sweet Venus-navel, and soft lady-smocks." - Ben Jonson. 
bears the cuckoo company during his short sojourn, it has received the name of Cuckoo-flower. It is sometimes called Meadow-cresses. The German name Wiesen-schaumkraut, foam of the meadows, is very poetical.

The genus comprehends nearly sixty species, five of which are natives of Britain. The bitter Lady's-smock, (Cardamine amara,) the only one with which the present species is likely to be confounded, is well distinguished by the broad, angular toothed leaflets of its upper leaves, its large white flowers and purple antliers. C. pratensis is often cultivated in gardens for the sake of its double flowers, and in this state, as if Nature had provided for the propagation of the species, new plants are produced from the leaflets when they come in contact with the ground.

Goats and sheep are fond of the herbage of this plant, cows dislike it, and horses and swine invariably refuse it. Bees and the Phalæna Aurora, frequent the flowers.

Qualities and General Uses.-This plant was formerly used as a salad in the same manner as water-cress, to which in its sensible qualities it bears a great resemblance, corresponding with the general character of the order Cruciferce, in the possession of antiscorbutic and stimulant qualities combined with an acrid flavour. Its odour is scarcely any; the taste is rather bitter and slightly acrid, and the stems possess these qualities in a greater degree than the leaves and fowers.

Medicar Properties and Uses. - This plant has often been confounded with the Water-cress, to which its leaves both in form and in sensible qualities bear no slight resemblance. It was formerly reckoned slightly excitant, and antiscorbutic, and was sometimes employed as a diuretic. Sir George Baker*, first brought the flowers of the plant into notice, as an antispasmodic, and on his authority they were admitted into the British Pharmacopœias. He relates five cases, viz: two of chorea sancti Viti, one of spasmodic asthma, an hemiplegia accompanied with convulsions on the palsied side, and a case of remarkable spasmodic affection of the lower limbs; the first two were curcd in less than a month; the two following were also removed, but in the last case the patient, after experiencing some relief, was seized with a fever which proved fatal. In a

* Medical Transactions, vol, i. p. 442. 
snbsequent edition of his work he says, "since the first edition of this volume, I have seen several instances of the good effects of the flowers in convulsive disorders." From the MS. of Dr. T. Robinson*, it also appears that lie had found the flowers a useful remedy in convulsions; and Heberden imagined that it assuaged the pain of gout. Greding $\uparrow$, who tried it in epilepsy, experienced but one instance of its good effects, and Lysons ${ }_{*}^{+}$ and Pearson $\S$ were not more successful. Michaelis \| relates a case of chorea, in which a drachm of the flowers given every six hours, effected a complete cure, so that the paroxysm did not return after the first dose, and in six weeks the patient was free from all traces of the disorder. In Cornwall, the flowering tops have been successfully employed for the cure of epilepsy, for several generations $\%$. In some northern counties they pound the whole plant, and express the juice, of which they give a wine-glassful for a dose. This they esteem an excellent remedy in scorbutic diseases and obstructions of the liver, spleen, or mesenteric glands, also in jaundice, dropsy, and diseases of the urinary organs.

The dose of the dried and powdered flowers is from a drachm to two drachms.

* Dale, Pharmacologia, p. 204.

+ Ludwig, Advers. Medico-pract. vol. iii. p. 564.

+ Practical Essays, p. 173.

§ Synopsis of Mat. Med. p. 465.

|I In Richt. Bibl. vol. v. p. 120.

T Willich, Domestic Encyclopædia, vol. iii. p. 58. 


\section{LVIII.}

\section{CUMINUM CYMINUM.}

Common Cumin.

Class V. Pentandria.-Order II. Digunia.

Nat. Ord. Umbellifere.

Gen. Char. Calyx of five setaceous, unequal teeth. Petals oblong, emarginate, with an inflexed point, erectly spreading. Fruit contracted from the sides. Carpels with five wingless ridges, of which the lateral ones are marginal. Channels with single vittæ.-Involucres two to four leaved.

Spec. Char. Leaves linear-setaceous, acute. Umbels three to five cleft. Involucres exceeding the fiuit, which is pubescent.

S Y NONYMES.

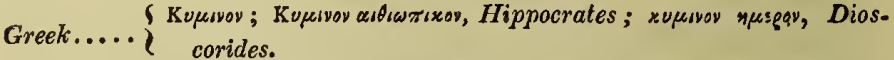

Cuminum semine longiore. Bauh. Pin. 146.

Cuminum sativum Dioscoridis. Ger. Em. 1066. Raii Hist.

Cuminum vulgare. Park Theatr. 887.

Fœniculum orientale, Cyminum dictum. Tourn. Inst. 312.

Cuminum Cyminum. Lin. Sp. $\mathrm{Pl}$. 375.

French.... Cumin; Cumin des près.

Italian.... Cumino; Cimino ; Comino.

Spanish.... Comino.

Portuguese Cuminho.

German... Kümmel ; Römischer Kümmel.

Dutch .... Komyn; Kumyn.

Danish... Kummen.

Swedish .. Spiskummen.

Polish .... Kmin.

Russ. ..... Timon.

Arabic.... Kemum.

Persian.... Zereh.

Tamool.... Siragum.

Sanscrit ... Jiraka. 
Descriprion.-The roots are annual, slender, elongated, nearly simple, fibrous and whitish. The stems are erect, sometimes procumbent, glabrous, branched, striated, and about eight inches in height. The leaves are alternate, distant, long, narrow, very smooth, slender, and divided into segments which are nearly capillary, bifid, or more frequently trifid. The flowers are small and disposed in a general umbel of about four radii, each supporting umbellules of a like number ; the involucres bifid or trifid, with capillary segments. The calyx is an indistinct five-toothed rim. The corolla consists of five obcordate, inflexed, emarginate petals of a white or purplish colour. The five filaments are furnished with simple anthers. The germen is inferior, large, ovate, terminated by two minute styles and simple stigmas. The fruit is ovate, prismatic, smooth or somewhat hairy, bladdery, with seven ribs and bearded intervals; the seeds are flat on the inner side, convex on the outer. Plate 12, fig. 3, (a) entire floret magnified; (b) fruit magnified.

This plant was originally brought to England from Egypt, where it is still found wild, as also in Ethiopia and many parts of Asia Minor. It is extensively cultivated in Sicily and Malta for the seeds, which are thence imported to the rest of Europe *. It flowers in June and July.

The generic appellation is supposed to be derived from kemum, the Arabic name for the plant, and of which there being but one species, the trivial name is merely a synonym. There can be little doubt that this plant is the kupsvov of the Greek writers, not however the xuubroy ayprov of Dioscorides.

Cumin resembles Fennel in its leaves and Bubon in its fruit. Miller was unable to obtain seed from the plant by the ordinary method of cultivation ; but he adds, " if it be raised in small pots in a hot-bed, by gradually inuring it to the open air, and carefully removing it from the pots to a warm border, it will flower freely, and in a warm season the seeds will be brought to perfection."

Quartites and general Uses.-Cumin seeds are used as a condiment in several ways. In Holland and Switzerland

* Miller says that in Malta it is called Cumino aigro, i.e. Hot Cumin, while the Anise is called Cumino dulce, or Sweet Cumin. It was cultivated in England in 1594, by Sir Hugh Plat.-See Plat's Garden of Eden, part ii. p. 134. 
they are used to flavour cheese, but the taste and smell thus imparted is: to some persons very disagreeable. In some parts of Germany they are put into bread to render it more pleasant and wholesome. Partridges and pigeons are excessively fond of the seeds, and hence they are used with success as a bait for those birds.

The seeds exhale a very strong, aromatic and heavy odour, the taste is penetrating, rather bitter and unpleasant. By infusion in water the greater part of their orlour is extracted, but very little of the taste ; in distillation, a strong pungent essential oil arises, smelling powerfully of the seeds*. Rectified spirit extracts the whole of the virtues of Cumin, and leaves them nearly uninjured by evaporation.

Medical Properties and Uses.-Cumin seeds † were ranked by the ancient pharmacologists among the four greater warm seeds, and they are reckoned superior to those of Fennel and Caraway. They are tonic and stimulant and have been celebrated by different authors as stomachic, carminative, diuretic, sudorific and emmenagogue, and recommended internally for flatulence, windy colic, vertigo, \&c. Cullen + thought them equal if not superior to any of the other carminative seeds. According to some anthors they constitute an excellent sudorific, and others have extolled their effects in

* From every pound of the seeds Baunè obtained half an ounce of essential oil.

+ It was a current opinion among some of the ancients that Cumin would make those who drink it of a pale visage. Dioscorides and Galen mention this. Avicenna (Canon. Medicinæ, vol. i. p. 293) says, the distilled water used as a lotion makes the countenance fair and strengthens the sight, as does the moderate use of it internally. But he adds, the too great use of it rakes the countenance sallow. 'Pliny informs us that the disciples of Porcius Latro, a famous master of the art of speaking, were reported to have used Cumin in order to imitate that paleness which their master lad contracted in his studies.'-Paris' Pharmacologia. Thus Horace,-

"—_ Proh si

Pallerem casu, biberent exsangue Cuminum."

Epist. xix. lib. i. lin : 18.

and Persius, -

" Rugosum Piper et pallentis grana Cumini."-Sat. v.

Our poet Spenser says,

"Rank smelling Rue, and Cumin good for eyes."

†. Mat. Med. vol, ii. p, 159. 
amenorrhœa and fluor albus. Their power of resolving swellings of the testicles and of the female breast, as well as cold and indolent abscesses, has been asserted but has not received much credence. "If their infusion taken very hot has sometimes provoked cutaneous perspiration, excited the secretion of urine, and facilitated the menstrual evacuation, it has only been in cases when the skin, the kidneys, and the uterus were in a state of debility and needed a stimulant to enable them to fulfil their functions. Moreover, applied in little bags to the skin, these seeds have sometimes contributed to the resolution of scrofulous tumours and other lymphatic enlargements; while the volatile oil obtained from them, by its action on the nervous system may well assuage head-ache, tooth-ache, \&c.: but the statement of its dissolving grumous milk in the breasts of females is probably fabulous." *

The seeds are given internally, powdered, in the dose of half a drachm, and of the aqueous or vinous infusion one draclim. Of the volatile oil three drops may be given in any proper excipient, and it is applied externally $t$ in a stronger dose mixed with the oil of sweet almonds, in the form of a liniment. A plaster is also prepared with the seeds, which has been much celebrated.

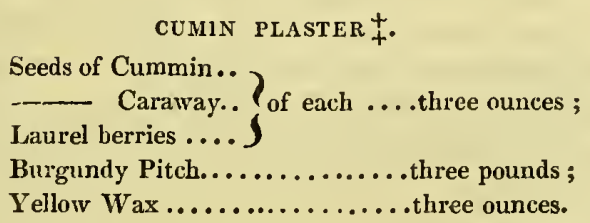

Melt the pitch and wax together, then add the other ingredients in powder and mix.

This plaster is reckoned stimulant, carminative, and discutient. It is applied to the lower belly in hysteria, flatulence, and a cold feeling of the bowels, and also to indolent tumours.

* Flore Med. tom. iii. p. 125.

$+\Delta$ rustic remedy for the colic is three or four drops of this oil upor toasted bread applied to the navel.

† Emplastrum Cumini.-Pharm. Lond. 
LIX.

\section{RIBES NIGRUM.}

\section{Black Currant.}

Class V. Pentandria.-Order I. Monogynia.

Nat. Ord. Grossularieze.

Gen. Char. Calyx superior, campanulate, five-cleft, bearing the petals and stamens. Style divided. Berry one-celled, many-seeded.

Spec. Char. Unarmed. Racemes lax, pilose, pendulous, with a solitary simple flower at their base. Flowers campanulate. Leaves dotted with glands beneath.

\section{S Y N O Y M E S.}

Latin.... $\left\{\begin{array}{l}\text { Grossularia non spinosa fructu nigro. Bauh. Pin. } 455 . \\ \text { Ribes fructu nigro. Ger. Em. 1593; Park Theatr. } 1562 . \\ \text { Ribes nigrum vulgo dictum folio olente. Raii Syn. } 456 . \\ \text { Ribesium fructu nigro. Dod, } 737 . \\ \text { Ribes nigrum. Lin. Sp. Pl. 291; Eng. Bot.t. 1291. }\end{array}\right.$

French.... Cassis; Groseiller noir.

Italian.... Ribes nero.

Spanish ... Ribes negro.

German.... \{ Schwarze Johaunesbeere; Gichtbeere; Johaunesbeeren mit

Dutch..... Zwarte Aalbezien.

Darish .... Scellor.

Bohemian.. Rybes Nebwjnos; Jana cerne.

Swedish ... S Swarta Winbœr; Distron.

Fir. ...... Ludin-maria.

Description.-The Black-currant is a deciduous shrub, from five to seven feet in height; the old wood covered with a dark brown bark, the younger branches of a lighter hue. The leaves are altcrnate, petiolate, subcordate, smooth, mostly three-lobed, 
much veined, irregularly serrated, of a bright green above, paler beneath, and sprinkled with numerous yellow glands secreting an odorous fluid; the petioles are tapering, about the length of the lcaves, furrowed above, and slightly pubescent. The flowers are disposed in racemes springing from the axils of the leaves of the young branches, pendulous and somewhat pubescent, with slender alternate pedicels, each of which is furnished with a small obovate ciliated bractea. The calyx is tubular, and divided at the rim into five ovate, spreading segments, of a pale yellowish green colour. The corolla is composed of five small erect petals of a light green colour, inserted into the throat of the calyx. The stamens are five, inserted alternately with the petals; the filaments short, straight, tapering; the anthers compressed, and two-lobed. The germen is roundish, one-celled, surmounted by a cloven style, with a small obtuse stigma. The fruit is a globose berry, crowned with the remains of the flower, black, shining, sprinkled with yellowish dots, onecelled, and filled with pulp. The seeds are numerous, suspended among the pulp by long filiform cords, attached to two lateral receptacles; the testa is externally gelatinous, adhering firmly to the horny albumen. Plate 15, fig. 2, $(a)$ the flower opened to show the stamens; $(b)$ a single stamen and petal; (c) the germen; $(d)$ the ripe fruit.

This shrub is a native of mountains, woods, and deserts * of the temperate and northern parts of Europe, Asia, and America, but unknown, in common with the whole tribe, to the tropics, Africa, and the South Sea Islands. It grows in woods and by river-sides in many places in Britain, flowering in May and ripening its fruit in July.

The term Ribes was applied by the Arabian physicians to an acid plant supposed to be a species of Rhubarb, (Rheum ribes, but Bauhin, who imagined it to be the Goosebcrry, denominated that shrub Ribes acidum. The fruit of the Black Currant is sometimes called by the peasantry quinsy berries, on account of its medicinal properties. Currants were originally called corinths from their resemblance to the small dricd grapes brought from that city.

* It is very common in some of the Lapland deserts. - Lin. Fl. Lapp. p, 70. In Siberia the berries sometimes grow to the size of a hazel nut. 
"Now will the corinths, now the rasps supply

Delicious draughts."-Philips.

There are six native species of Ribes, of which the one here selected for illustration, and the Red Currant, (Ribes rubrum,) together with the Gooseberry, (Ribes Grossularia,) are most common. They are among the most esteemed fruits of cool and temperate climates, where alone they come to perfection. It is singular that no varieties have been raised of the Black Currant, nor will it produce hybrids as far at least as has been tried with the other cultivated kinds. Dr. Withering has noticed a curious change of the petals into stamens. The leaves are eaten by goats and sheep.

Qualities and general Uses.-The fruit of the Black Currant, though disagreeable to many persons in its recent state, is much used in forming a pleasant and wholesome wine, and a grateful preserve. In Russia and Siberia, a wine is made of the berries alone, or with the addition of honey; and also a distilled spirit*. The leaves are used to tincture common spirits so as to resemble brandy. The young leaves, fresh gathered and infused for a moment in hot water and then dried, have been recommended as a substitute for common tea.

The odour of the berries is peculiar and fragrant and has been compared to that of the Bird-Cherry (Prunus Padus) or of Savine (Juniperus Sabina); the taste is acidulous and sweetish. The leaves have also a strong scent, which exudes from the glands occurring on their under surface. The berries submitted to analysis, yield sugar, malic, and citric acids, volatile oil, a large quantity of jelly, and a violet colouring matter. The volatile oil is bitter and aromatic ; it resides also in the flower, stalks, leaves, and bark of this shrub, and is supposed to give the peculiar aroma by which they are characterised.

Medical Properties and Uses.-The fruit is considered refrigerant, aperient, stomachic, and anodyne. The jelly prepared from it has been used from time immemorial as a popular remedy in sore-throat and quinsy $\downarrow$. Dale $\ddagger$ speaks of its effi-

* Wargs Hjelpreda, p. 494.

+ Vide Raii Hist. Plant. vol. ii. 1. 1486.

† Pharmacologia, p. 32l. 
cacy in these diseases, and Sir George Baker * considers it an invaluable remedy. A decoction of the leaves or bark has been used as a gargle for the same purpose. The leaves have been celebrated for their diuretic and detergent properties, especially by Forestus, $\uparrow$ who directs a handful of them to be boiled in a pint and a half of water, down to a pint, which is to be taken in difficulty or suppression of urine. It is to be observed, however, that he generally prescribed it in combination with the seeds of wild carrot.

The mode of preparing the rob or jelly needs no description.

SYRUP OF BLACK CURRANTS.

Take of depurated juice of Black Currants, one pound;

White sugar .............. two pounds.

Make a syrup over a gentle fire.

This in common with the jelly may be taken to almost any extent in fevers, and diluted, as a gargle in inflammatory sorethroat.

\section{CONSERVE OF BLACK CURRANT}

Take of Black Currant leaves, bruised and reduced to a fine pulp, one part;

White Sugar ......................... two parts.

Beat them together, and heat in a sand bath, in a close vessel, until the sugar is dissolved.

'The Red Currant is equally well-known with the foregoing, and the fruit is considered nutritive, refrigerant and laxative. The juice diluted with water and sweetened with sugar or honey forms a very agreeable drink in hot weather, and very proper for assuaging thirst both in health and disease. Its different preparations have been used with advantage in bilious, nervous, and putrid fevers, likewise in small-pox, measles, chronic diseases of the skin and scorbutic affections. It is prescribed chiefly for persons of a bilious or sanguine temperament: in constitutions of a contrary kind it is apt to occasion flatulence and indigestion. An infusion of the young roots has been used in eruptive fevers.

* Phil. Trans. vol. xli. p. 656.

† Opp. Lib. Obs. 18, 19.

† Van Mons. Pharmacopíc usucllc, \&g., Louvain, 1821. 


\section{LX.}

\section{BELLIS PERENNIS.}

\section{Common Daisy.}

\section{Class XIX. Syngenesia.-Order II. Polygamia SuPERfLua.}

Nat. Ord. Couposita.

Gen. Char. Involucre hemispherical, simple, its scales equal. Receptacle naked, conical. Pappus none.

Spec. Char. Scape naked, single-flowered. Leaves spatulate, obovate, crenated.

SYNONYMES.

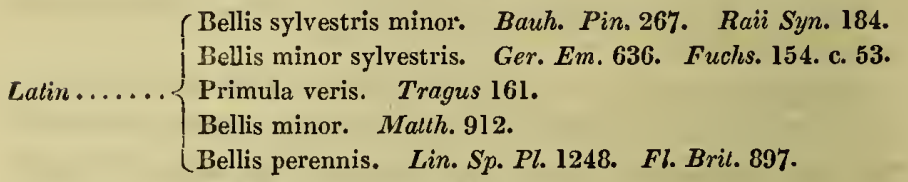

French...... Marguerite; Petite Marguerite; Paquerette.

Italian...... Margherita; Margheritina.

Spanish...... Margarita; Bellorita; Maya.

Portuguese .. Bonina.

German..... Gänseblume; Margarethenblume; Marienblume.

Dutch....... Maagdelieven; May-zoetjes; Margarieten.

Bohemian ... Sedmikrasa; Matecnjk-mensji.

Description.-The root is perennial, creeping, truncate at the end, and furnished with numerous fibres. The leaves are numerous, radical, prostrate, obovate, spatulate, slightly hairy, and crenate at the margin. The scapes are round, hairy, tinged with pink, from two to four inches in height, each supporting a single flower. The involucre is hemispherical, simple, composed of several lanceolate equal scales, placed in two rows. The 
receptacle is conical, naked, and dotted. The florets of the ray are pistilliferous, ligulate, slightly notched, and of a white colour, tipped with crimson; those of the disk are numerous, perfect, tubular, five-toothed, of a yellow colour ; the filaments are hair-like', very short; the anthers notched, coliering into a cylinder. The germen is inferior, obovate, with a filiform style, and a bifid, crescent-shaped stigma. The fruit is a small, obovate, compressed pericarp, destitute of pappus, and containing a single, erect seed. Plate 15, fig. 3, (a) floret of the circumference or ray; $(b)$ floret of the disk magnified; $(c)$ the anthers forming a tube round the style, magnified.

This modest, crimson-tipped flower, the delight of all ages, is as frequent as it is beautiful. It gems our meadows and pastures from March to November, most abundantly in the height of spring and the beginning of summer, but a few may be seen at all seasons; -

"It smiles upon the lap of May,

To sultry August spreads its charms,

Meets cold October on his way,

And twines December's arms."

Montgomery.

Shelley, in his exquisite dream of spring-flowers, introduces

"Daisies, those pearled Arcturi of the earth, The constellated flower that never sets!"

The generic name is derived from the Latin bellus, pretty. It was also called Margarita, (a pearl,) of which there are synonymes in many of the continental languages. The bold and cheerful manner in which its petals expand to the light of day, and their habit of closing at night and against rain, suggested the name of daisy, or as Ben Jonson calls it days-eye. Chaucer gave it the same designation; speaking of "Aprilis and his plesant showres," he says

"Of whose invencion lovirs may be glade,

For they bring in the Kalendis of Maie,

And they with countenance demure, meke,

Owe worship to the lusty flowres alwaie.

And in special, one called eye of the daie,

The daisie, or flowir white and rede."

His affection for this flower manifests itself in many parts of his poems, and he describes in beautiful language its habit of 
closing at night, and opening in the morning. Thus, in the "Legende of goode Women ":

"Of all the floures in the mede

Than love I most these flowres white and rede,

Such that men call Daisies in our toun.

To them I have so great affectioun,

As I sayd erst whan comen is the Maie,

That in my bedde there daweth me no daie,

Than I n'am up and walking in the mede

To see this floure agenst the sunne sprede,

Whan it upriseth early by the morrow,

That blissful sight softeneth all my sorrow.

As soon as ever the sunne ginneth west

Go seen this floure how it will goe to rest,

For fear of night, so hateth she darknesse,

Her chere is plainly spred in the brightnesse

Of the sunne, and there it will unclose.

And leaning on my elbow and my side,

The longe day I shope me to abide,

For wothing else, and I shall not lie

But for to look upon the daisie;

That well by reason, men it call may

The daisie, or else the eye of the daie,

The Emprise and floure of floures all

I pray to God that faire mote she fall,

And all that loven floures for her sake."

Several varieties are cultivated in gardens, and the proliferous, childers, or hen and chicken daisy is very curious. The plant is refused by horses, sheep, and cows.

Qualities and general Uses.-The leaves of the daisy, though somewhat acrid, have been eaten as a spring salad, or boiled like spinach. A decoction of the root in milk is sometimes given to young puppies to obstruct their growth, but with what success we cannot determine.

The leaves and flowers, which are the parts usually employed medicinally, have a sharp and somewhat astringent taste, but no smell. Geoffroy * states, that they yield by analysis a considerable portion of oil and ammoniacal salt. The sensible qualities of the root, however, are far more powerful. According to Lewis $\uparrow$ " it has a subtle penetrating pungency, which is not dissipated by drying, is dissolved both by water and

* Tract de Mat. Med. vol. iii. p. 170.

† Mat. Med. ed. Aikin, vol. i. p. 205. 
spirit, and on inspissating the solution is left in great part behind in both the extracts." He compares it to contrayerva, and adds "though at present disregarded, it promises to become a medicine of no small virtue."

Medical Properties aNd Uses.-Whatever poetical fame may have encircled the daisy's coronet, its reputation as a medicine has dwindled almost to nothing. The ancient physicians were very lavish in its praise, and for its supposed vulnerary properties it received the Pharmacopoial name of consolidx minima. Fabricius * and Ettmuller 7 speak of its efficacy in promoting the absorption of extravasated blood, whether from wounds, contusions, or any other cause. Matthiolus affirms that wounds of the thorax which have penetrated even its cavity have been cured by this remedy; and Konig $\neq$ goes further than this and asserts, that in lesion of the lungs it has proved extremely beneficial. Hence it came to be considered as an anti-pleuretic, and was prescribed in nearly all the diseases to which the lungs are incident; also in liver complaints, agues, dropsy, asthma, and scrofulous swellings. The expressed juice $\S$, or a decoction of the leaves and flowers was usually given internally, and the bruised herb, either alone or mixed with lard, was applied externally. Ettmuller $\|$ on the authority of Michaelis relates the case of a cook, who was cured of an obstruction of the lungs by means of tlie expressed juice.

Some of the moderns have esteemed it beneficial in phthisical complaints, and it still occupies a place in a few of the continental pharmacopocias. A conserve is prepared with the flowers, and a syrup with the expressed juice: the tincture of the flowers 9 contains a portion of sulphuric acid, to which its reputed soothing and refrigerant properties are doubtless attributable. The expressed juice of the plant, in the dose of half an ounce, is sometimes given by the poor to their infants as a laxative; they also consider it a remedy for fluor albus. The root of this plant, which is, as already observed, the most potent in sensible qualities, may probably be found at some future day not inert as a medicine.

- In Simon Pauli Quadrip. p. 29.

+ Opera Med. vol. i. p. 523.

+ Regn. veg. p. 755 .

$\S$ "The juice of the leaves and roots," says Gerard, "snift vp into the nosthrils purgeth the head mightily of foule and filthy humors and helpeth the megrim. * * The leaves stamped, take away bruises and swellings; whereupon it was called in old time Bruisewort." Lib. cit. p. 637.

\| Loco cit. See also Mindererus in Medic. Melit.p. 77 ; Eysel Bellidograph, p. 26; and Bechstein, "Concise History of Plants," Leipsic, 1797.

q Pharmacopæia Würtembirgica. 


\title{
LXI.
}

\section{LEONTODON TARAXACUM.}

\author{
Common Dandelion.
}

\section{Class XIX. Syngenesia.-Order I. Polygamia EQUALIS.}

\section{Nat. Ord. Composite.}

Gen. Char. Involucre imbricated with scales, of which the putermost are often lax and flaccid. Receptacle naked. Pappus stipitate, simple.

Spec. Char. Outer scales of the involucre lax and reflexed. Leaves runcinate, toothed, glabrous.

\section{S Y N ON Y M E S.}

Greek....... «фажn? Theophrastus.

(Dens leonis latiore folio. Bauh. Pin. 126.

Dens leonis. Ger. Em.290. Raii Syn. 170. Dod, 625.

Hieracium majus.' Trag. 262.

Latin ..... \{ Hedypnois Taraxacum, Scop. Carn. ii. n. 957.

Taraxacum officinale. Willd. Hort. Ber. $\mathbf{7 7 2}$.

Leontodon 'Taraxacum. Lin. Sp. Pl. 1122. Flora Brit. 822. Eng. Bot, t. 510.

French .... Pissenlit; Dent de lion.

Italian..... Piscia en letto; Dente di leone.

Spanish .... Diente de leon; Amargon; Chicoria salvage.

Portuguese... Dente de leāo.

German .... Löwenzahn; Pfaffenröhrlein; Dotterblume; Seichblume. Dutch ..... Paardebloem; Paapenkruid.

Belgic ...... Paardebloem; Kankerbloem; Mol Salade ; Pis in't bed.

Danish...... Loevetand.

Bohemian.... Plesska.

Swedish...... Lejontand; Maskrosor.

Polish ...... Papawa ziele; Wolowe oczy.

Russ. ..... Molotschai trawa. 

Description.-The root is perennial, fusiform, fleshy, of a whitish-asl colour within, brown externally, and furnished with numerous spreading fibres. The leaves are all radicali spreading, smooth, runcinate; the lobes acute, unequal, toothed, and pointing downwards. Several scapes arise from the same root; they are erect, cylindrical, smooth, brittle, tubular, and crowned with a single capitulum, or head of flowers. The involucre is imbricated and oblong, and consists of two rows of scales, of which the inner are nearly equal, linear, and parallel; the outer shorter, paler green, flaccid, and reflexed. The florets are very numerous, equal, perfect, ligulate, truncate, fivetoothed, of a bright yellow externally, inclining to purplish beneath. The filaments are capillary and short, with the anthers united into a cylinder. The germen is obovate, furrowed, surmounted by a slender style longer than the stamens, and terminated by two revolute yellow stigmas. The receptacle is convex, naked and dotted. The fruit is a small, dry, oblong pericarp, supporting the pappus, - a long, simple column, crowned with radiating silky hairs. The seed is solitary and erect, without albumen. Plate 16, fig. 2, (a) a single floret; (b) the pericarp, (commonly called seed,) crowned with the pappus or down.

Few plants are more common and provided with more effectual means of propagation than this: the seeds are wafted far and wide by the winds, and the root is so vivacious that the smallest piece of it will give rise to a new plant; hence, it often intrudes into gardens, and is generally looked upon as a troublesome weed. It is a native of Europe, from Italy to the Alps and woods of Lapland. It flowers sparingly in March, and abundantly from the second week in April to the end of May, after which it begins to decline, though flowers may be found till late in autumn.

The term Leontodon is derived from $\lambda \varepsilon \omega v, a$ lion, and ofous, $a$ tooth, from the tooth-like margins of the leaves, hence also the old specific name dens-leonis, and the French dente de lion, of which the English Dandelion is a corruption. Taraxacum is

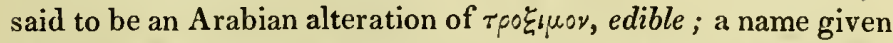
also to the Seris or wild Succory (Cichorium Intybus). The term caput monachi, or monk's-head, was probably suggested by the bald appearance of the receptacle after flowering. The 
vulgar name by which it is familiar to children, the French Pissenlit*, and equivalent synonymes in other languages, indicate the long and general acquaintance of the people with its diuretic qualities.

The flowers of the Dandelion are very sensible to atmospheric changes, regularly opening in the morning in fine weather, and closing in rainy weather and at night. When the sun's rays first touch them on a summer's morning, this sensibility is rendered very obvious in the motion of the florets.

This plant is greedily devoured by hogs, it is relished also by goats, but sheep and cows dislike it, and horses invariably. refuse it. Many small birds live on the seeds.

Qualities AND General Uses.-In spring, when the leaves are tender and nearly white, they are used as a salad in many parts of the continent, and occasionally by the poorer class in this country. In France, the blanched leaves are eaten with bread and butter. The root dried and roasted has been proposed as a substitute for coffee, for which purpose it is quite as well adaptcd as Succory. Murray states that a decoction of it is used by the poor of Gottingen, who find it to resemble coffee in no slight degree. The roots are also eaten raw as a salad, and are boiled by the Germans like salsafry and scorzonera.

The leaves and stem, but particularly the root, abound in a milky juice, which is inodorous and slightly bitter, accompanied with a sweetish saline taste. It reddens the vegetable blues according to Hermbstadt, by the tartaric acid it contains. The other constituents are supposed to be extractive matter, gluten, and a bitter principle, which does not appear to be resinous. Dr. John detected caoutchouc in the juice, notwithstanding ether has scarcely any effect upon it. Water extracts its virtues better than alcohol. Infusion of galls, solutions of nitrate of silver, nitrate of mercury, acetate of lead, and sulphate of iron precipitate its decoction, and are therefore incompatible with it. Neither the expressed juice, nor the extract will keep

- Many a little wight may be seen shrinking with horror lest he should touch the plant, and experience the unfortunate effects which popular tradition has attached to mere contact with it. Experience probably soon renders him bold, and he may then be seen blowing off the feathery fruit, when ripe, to find out "what's o'clock." 
long uninjured. The recent root, full grown and procured in autumn, should alone be employed.

Medical Properties and Uses.-Although this plant cannot be fully identified with the descriptions by which it is supposed to be indicated in the earliest medico-botanical works, it is distinctly signalized by later authors. Avicenna*, in his chapter "De cura oppilationum hepatis," mentions it under the name of taraxacon. Tragus speaks of its virtues in burning fevers, and Gerard recommends it in jaundice, in which disease Van Swieten $\uparrow$ found it very beneficial, either in the forn of a decoction or the juice by itself, or mixed with whey. Ettmuller prescribed it in chronic maladies supervening to obstructions of the liver and mesenteric glands, in intermittents, and in low putrid fevers. He also applied the bruised leaves externally, in the form of a poultice, to the back of the neck, in affections of the eyes. It excites small pustules and blisters; and he affirms that it removes speeks from the eyes, and inflammation. He employed it in the same manner for headaches. He adds, the juice applied on linen is efficacious against all kinds of sores and excoriations. Parkinson writes "who so is macilent, drawing towards a consumption, or ready to fall into a cachexy, by the use hereof for some time together, shall find a wonderful help." Fuller states that he gave the expressed juice in many obstinate scorbutic and leprous affections of the skin, with the best effects wine or fermented decoction of Dandelion in hectic fevers, dropsy of the chest, asthma, retention of urine, and in inflammation of the eyes. Bergius || found a decoction of the root in whey or broth extremely useful in diseases of the liver. More recently Dr. Pemberton $\uparrow$ observes that he has seen great advantage result from using the extract in chronic inflammation and incipient scirrhus of the liver, and in chronic derangement of the stomach. Dr. W. Philip considers it well adapted for cases in which bile is def-

"Op. cit. vol. i. p. 764.

† Comment. tom. iii. p. 102.

$¥$ See also Leidenfrost, Dissert. de succis herb. rec. p. 27; Febure Chemie, vol. ii. p. 408.

§ Dissertatio de Taraxaco, p. 31.

If Mat. Med. vol. ii. p. 649.

T Diseases of the Abdominal Viscera, p. 42. 
cient without an impaired state of the stomach. The statement of Zimmermann* as to its efficacy in pulmonary diseases is confirmed by Dr. J. Clark $\uparrow$, who considers Taraxacum " a very valuable medicine in tuberculous constitutions, from its power of diminishing abdominal plethora, and its especial influence on the urinary and biliary secretions." Hufeland \& strongly recommends it every spring in the treatment of scrofula, and the translator of his work regards it as an efficacious remedy in the mesenteric disease of infants, and in the congestions of the abdominal viscera which are the consequences of intermittent fevers.

On the continent, the expressed juice of the root and leaves of Dandelion is thought superior to any preparation, given in the dose of two to four ounces, two or three times a day. If this cannot be borne on the stomach by itself, it may be improved by some aromatic, or a little wine and sugar. But as the juice cannot always be obtained, an extract and a decoction are prepared, which form a good substitute for it.

EXTRACT OF DANDELION $\$$.

Take of fresh Dandelion root, bruised, one pound;

Boiling water............. one gallon.

Macerate for twenty-four hours, then boil down to four pints; strain the hot liquor, and evaporate it to a proper consistence.

A preferable mode of forming the extract is to bruise the roots in a marble mortar, express the juice, and set it aside. Then bruise them a second time, boil them in a sufficient quantity of water, and evaporate by a gentle heat to the consistence of a syrup. Add this extract to the expressed juice, and evaporate the whole in shallow dishes until it acquire a firm consistence.

The extract is exhibited in chronic inflammation and induration of the liver; also in jaundice, and chronic affections of the digestive organs : the dose, from ten grains to a scruple, united with sulphate of potass. Dr. Clark usually prescribes it in combination with some tincture of hops and aromatic water, and in this form finds no difficulty in getting children. to take it for weeks.

- Fragmente über Frierdrich den Grossen 1790, vol. iii. p. 82.

+ Treatise on Pulmonary Consumption, p. 329.

† Traité de la Maladie Scrophuleuse, p. 275.

§ Extractum Taraxaci._Pharm. Lond. 


\section{DECOCTION OF DANDELION *}

Take of the fresh herb and roots of Dandelion, four ounces;

Water ..................... two pints.

Boil to one pint, and strain the expressed fluid.

Dose from two to three ounces, twice a day. The addition of cream of tartar renders it more efficacious $\dot{\dagger}$.

If an aromatic be required, an ounce of angelica root and the same quantity of liquorice root may be added. Some of the continental physicians order a decoction to be made with equal parts of Dandelion root and root of Couch-grass (Triticum repens), to which is added a little syrup or oxymel.

- Pharm. Dubl.

+ Bergius recommends the recent leaves of Dandelion and wood-sorrel, boiled in whey or in water, to which the yolk of an egg is added, and a little cream of tartar. He ordered his patients to continue this regimen for several weeks, and he found it useful in indurations of the liver, biliary concretions, and dropsy of the belly.-Op. cit. 


\section{LXII.}

\section{LOLIUM TEMULENTUM.}

Bearded Darnel.

Class III. Triandria,-Order II. Digynia.

Nat. Ord. Graminefe.

GEN. Char. Glume of one valve, solitary, many-ffowered Palece of two unequal valves, the exterior awnless, or with an awn below the extremity.

SPEC. Char. Spikelets nearly as long as the glume. Florets equal in length with the rigid awns. Root annual.

SYNON Y MES.

Greek .... aspe.? Theophrastus.

Latin .... $\left\{\begin{array}{l}\text { Gramen loliaceum, spicâ loggiore, seu Lolium Diogcoridis. } \\ \text { Baut. Pin. 9. } \\ \text { Lolium album. Ger. Em. 78. Raii Syn. } 395 . \\ \text { Lolium. Dod.529. } \\ \text { Lolium verum Gesneri. Boerh. ii. 157. } \\ \text { Lolium temulentum. Lin. Sp. Pl. 122. Fl. Brit. 150. Engs } \\ \text { Bot. t. 1164. Hort. Gram. I. 20. t. 26. }\end{array}\right.$

French.... Ivraie; Ivraie annuelle; Yrraie ordinaire.

Italian .... Loglio; Zizzania.

Sparish.... Joyo; Zizaǹa.

Portuguese. Joyo.

German .. Jährige Lolch ; Trespe; Ruheweizen.

Dutch .... Dolyk.

Danish... Heyre.

Swedish ... Därrepe.

Polish .... Kakol.

Russ. .... Kukol.

Description. - The root is annual, tortuous, and fibrous. The stem is erect, cylindrical, striated, rough towards the sum- 
mit, about three feet in height, and clothed at the joints with long, flat, acuminate leaves which are rough on the upper surface, and of a pale green colour; the ligula is short, obtuse, and slightly notched at the end. The inflorescence is an erect spike, from four to six inches long, with numerous sessile spikelets arranged alternately in two rows along the common axis or rachis, which is flexuous, rough, and channelled; each spikelet or locusta contains about seven flowers. The glume* is lanceolate and solitary, situated at the base of the spikelets, and rather exceeding them in length. The paleæ $t$ consist of two unequal valves, the exterior of which is acute, membranous at the edge, cleft at the point, and keeled, sending forth a long, rigid awn below the extremity; within these a minute elliptical scale + is occasionally found. The three stamens have capillary filaments shorter than the paleæ, and oblong versatile anthers, notched at each extremity. The germen is turbinate, surmounted by two very short styles, terminated by feathery stigmas. The pericarp $\S$ is membranous, elliptical, compressed, convex on one side, attached to the inner valve of the paleæ, and scarcely distinguishable from the seed. Plate 15, fig. 4, (a) glume; $(b)$ paleæ and stamens; (c) germen and styles.

This species of Darnel is a common weed in many parts of England, growing in fields among wheat $\|$, barley and flax. It flowers in July.

- He was met ev'n now

Crowned with rank fumiter and furrow weeds,

Darnel, and all the idle weeds that grow

In our sustaining corn."

\section{Shakspeare.}

The term Lolium las been thought by some to be derived from $\lambda$ aiov o $\lambda \varepsilon i v$, to ruin the corn, by others from $\delta 0 \lambda .65$, counterfeit, in conformity with an opinion entertained by the ancients, and not yet exploded in every country that the plant is merely wheat, or some other grain in a degenerate state. This doctrine of the transmigration of vegetables was carried to an extravagant height ; it was believed that circumstances being unfavour-

* Calyx of Linnæus.

+ Corolla of Linnæus.

$\ddagger$ Nectary of Linnæus.

$\$$ "Caryopsis" of some authors.

II See Virgil, Georgic i. 1. 154, and Ovid Met. lib. v. 1. 485. 
able, wheat would change into rye, rye into barley, barley into darnel, darnel into brome-grass, brome-grass into oats, and so on; and that in favourable soils and situations these transmutations would be reversed ${ }^{*}$. Virgil promulgates the former opinion ;

"Grandia sæe quibus mandavimus hordea sulcis, Infelix lolium, et steriles dominantur avenæ."

And Plautus ; Ecl. v. 1. 36.

"Mirum est lolio victitare te, tum vili tritico." Miles Glor. act ii. sc. iii. 1. 50.

From Lolium perhaps originated the term LoLtard, applied by their enemies to the Waldenses in Germany, and the followers of Wickliffe in this country ; to indicate that they were pernicious weeds in Christ's vineyard, choking and destroying the pure wheat of the gospel. Milne thinks the expression $\zeta_{b} \zeta_{\alpha}$ เ 6 which occurs in the 13th chapter of St. Matthew's gospel would have been better translated darnel than tares $\uparrow$. The French call it ivraie from ivresse, drunkenness; hence, probably the English ray-grass; in both languages, however, ivraie and ray-grass are applied indiscriminately to the different species of Lolium.

The bearded Darnel + is the only deleterious individual in the whole family of the grasses. It varies greatly in the length of its awn; it must not, however, be confounded with the perennial Darnel, or Rye-grass (Lolium perenne), which is often ermployed with clover for artificial pasture and hay, and is much esteemed by the agriculturist. The last mentioned species has linear-oblong compressed florets, destitute of awns, and the spikelets are much longer than the glume.

Qualities.-The constituent principles of the seeds of Darnel appear not to have been investigated by chemists. We only know that they are inodorous, slightly bitter, and disagreeable $\$$

* The great Lord Bacon was a firm believer in these lusus natura; he says, "it is certain that in sterile years, corn will grow to another sort. * * It is not impossible and I have heard it verified that upon cutting down of an old timber-tree, the stub hath put out sometimes a tree of another kinde ; as that Beech bath put forth Birch."-Sylva Sylvarum, cent. vi. p. 111.

+ Milne's Indigenous Botany, vol. i. $\quad \ddagger$ Cheal in provincial dialects. $\S-$ "Want ye corn for bread, "Twas full of darnel, do you like the taste?"

Shakspeare. 
to the taste, and contain sufficient acid to redden the vegetable blues. The seeds are reported to be eaten with impunity by hogs, and though fatal to geese, to be useful food for fattening chickens. According to Linnæus, the herb is sometimes eaten by sheep.

Poisonous Properties.-Its poisonous effects on dogs are thus noticed by Seeger. He gave three ounces of a decoction of the flour to a dog, in five hours he was seized with a general trembling, incapacity to walk, and difficulty of breathing: four hours subsequently, he fell into a profound sleep and became insensible, but the next day he was nearly recovered. In other of these animals submitted to experiment, it caused vomitings, convulsions, and an abundant excretion of urine, and perspiration. It is said to prove fatal to horses.

Theophrastus, Dioscorides, Aristotle, Pliny, and most of the sages and poets of antiquity, were acquainted with the poisonous effects of this plant on the human frame. The most prevalent opinion was that it caused blindness: hence with the Romans "lolio victitare," to live on darnel, was often applied to a dimsighted person; and in Plautus when Palostro enquires what Sceledrus meant by his living on darnel, he receives for answer "Quia lusciosus es" because you are purblind. Ovid (Fasti i. 692) thus adverts to it :

" Et careant loliis oculos vitiantibus agri

Nec sterilis culto surget avena solo."

Gerard says "the new bread wherein darnell is, eaten hot causeth drunkenesse ;" and Linnæus referring to this property, states that the greater part of its virulence is destroyed in stale bread, but when fermented in beer it retains its stupifying qualities*. Seeger $\uparrow$ relates that five persons having eaten about five pounds of oaten bread which contained darnel, were attacked in two hours with frontal headache, vertigo, drowsiness, pain in the stomach, and great trembling of the tongue; deglutition and pronunciation were also much impeded. There was also vomiting attended with great effort, extreme lassitude, cold sweats, and violent tremors over the whole body. In other cases paralysis, delirium, and death itself have occurred. $\mathbf{M}$.

* It is to be feared that like other narcotics, it is sometimes used to adulterate beer in this country; else why is the plant cultivated?

+ Orfila Toxicol, Gen. ii. p. 466. 
Cordier * found by experiment on himself with pure darnel flour, which he took to the amount of six drachms, that it occasioned confusion of sight and ideas, great debility and languor, tremors, drowsiness, succeeded by efforts to vomit, by which much of the bread was rejected. Hence it appears that darnel acts on the animal economy as an acrid narcotic, exciting the gastric apparatus at first, and then the nervous and cerebral systems, from which result its narcotic and intoxicating effects. The deleterious effects of this grain on a family who partook of it mixed with wheaten bread, are recorded in the London Medical and Physical Journal, for $1799 \%$. In addition to the symptoms already described, these persons experienced great pain and tightness of the calves of the legs, and in one of them who partook of the bread when new, and again subsequently, and who was not seized with vomiting, the pain and inflammation were succeeded by gangrene, and he was compelled to undergo the amputation of both legs. Some years ago about eighty persons in the poor house of Sheffield, after breakfasting on oatmeal porridge, were seized with the usual symptoms of poisoning by darnel. Violent agitation of the limbs, convulsive twitchings, small tremulous pulse, confusion of sight, and wildness of the eyes were observed in nearly all these persons, and they all pointed to the forehead as being the seat of torturing pain. Copious draughts of vinegar were administered, and before night the majority of them were greatly relieved; but for the two following days they complained of stupor and weakness of sight, and two of the number were affected with convulsions for some time, but they all eventually recovered $¥$. A similar accident happened at Freyburg, in the House of Correction, and was ascribed to the same source $\S$. The foregoing cases clearly indicate the presence of narcotic, combined with acrid properties, but in the following instance it appeared to act solely as an irritant on the bowels. A farmer, his wife, and a servant partook of bread made with darnel and wheat, but the two latter were so violently affected with vomiting and purging, that they refused to eat any more of it. He persevered, himself, however,

* Sur les Effets de l'Ivraie.-Nouv. Journ. de Med. vi. p. 379.

+ Vol. i.p. 423.

\# Med. and Surgical Journal, 1812, vol. xxviii. p. 183.

§ Buchner, 'Toxikologie, p. 374 ; see also EdinburghJournal, vol. i. p. 106. 
until the fourth day, when he was attacked with the most serere fits of colic, and died in a few hours*.

Epidemic fevers of the worst description'have also been attributed to the extensive consumption of this grain, but no satisfactory evidence of this has been adduced. De Candolle thinks that its pernicious effects have been much exaggerated, and he asserts that in times of scarcity, numerous individuals have eaten it without inconvenience. Unripe and putrid wheat seems to approach in a considerable degree to the properties of darnel, and the analogy between its effects and those produced by the ergot of rye is very striking; the latter is known to be an extraneous production; a disease occasioned by the growth of a parasite. No one has thought of attributing the anomalous qualities of darnel to a similar source: we might, however, if there were ground for such an hypothesis, expect à priori, that they were owing to a very minute parasitical fungus. Parmentier asserts that the seeds of darnel may be divested of their acridity, by drying them in an oven before they are ground into flour. The bread thus prepared is no longer injurious, especially if it be not eaten till it is quite cold. In conclusion, we must regret that chemical analysis has not been employed to throw some light on the nature of this extraordinary vegetable.

The best mode of treatment in cases of poisoning by darnel, is to administer an emetic without delay; after which, diluent and acidulous drinks should be given, or some diffusible tonic, according to the nature of the symptoms.

Medical Properties and Uses.-Darnel was once used medicinally, though now generally abandoned. It was recommended by Aretæus in pleurisy, and by others of the ancients in gout, diarrhœa, and profuse menstruation. As a topical application, it was considered detersive and resolvent. According to Boerhaave, it resists putrefaction if applied externally; and from its cleansing qualities proves highly efficacious in disorders of the skin.

* Histoire de la Societé Royale de Med. à Paris, tom. ii. p. 297. 


\section{LXIII.}

\section{ANETHUM GRAVEOLENS.}

\section{Common Dill.}

Class V. Pentandria.-Order II. Digyn ia

Nat. Ord. Umbeluifere.

Gen. Char. Calyx obsolete. Petals roundish, involute, with a subquadrate retuse point. Fruit dorsally compressed, nearly lenticular; girt with an even margin. Carpels with five equal, filiform ridges, of which the three intermediate ones are acutely carinate; the lateral ones more obsolete, vanishing into the margin. Channels with broad, single vittæ. Seed rather convex, plane in front.-Involucres none.

Spec. Char. Fruit elliptical, girt with a flat dilated margin.

\section{SY NONYMES.}

Greek .... a. ayntov.

Anethuim hortense. Banh. Pin. 147.

Anethum. Ger. Em. 1033. Raii Hist. 415. Park. Parad. t. 493, f. 4. Fuchs. 30, c.9.

Latin ..... \{ Pastinaca Anethum. Spreng. in Schullz syst. vi. p. 587.

Selinum Anethum. Roth. Fl. Germ. i. p. 143.

Anethum Graveolens. Lin. Sp. Pl. 377. Willd. i. p. 1469.

Gartn. Fruct. i.91.

French.... Aneth; Anet; Aneth odorant; Fenouil puant.

Italian.... Aneto.

Spanish... Eneldo.

Portuguese. Endro.

German ... Dille; Dill.

Dutch ..... Dille.

Danish... Dil.

Swedish.... Dill.

Bohemian . Kopr zahradny.

Polish .... Kopr.

Hindostanee Sowa.

Sanscrit .. Misreya; Sitasiva.

Javanese.. Mungsi.

Description.-The root is annual, fusiform, whitish, and fibrous. The stems are cylindrical, glabrous, and striated, the 
striæ alternately white and reddish, somewhat branched, leafy, and attaining the height of two feet. The leaves are alternate, glaucous green, twice or thrice pinnate, with slender acute segments, and broad membranous sheathing footstalks. The flowers are disposed in broad, flat, terminal umbels, destitute both of general and partial involucre. The calyx is an obsolete margin. The petals are five in number, of a bright yellow colour, ovate, equal, concave, with a broad retuse inflexed point. The five stamens are spreading, incurved, longer than the petals, yellow, and furnished with roundish anthers. The germen is inferior, ovate, crowned by the disk, and terminated by two short recurved styles with simple stigmas. The fruit is elliptical, compressed, divided into two carpels which are flat on the inner side, convex on the outer, marked with five ridges, of which the lateral ones are indistinct, and margined with a pale yellow membranous expansion. Plate 16, fig. 1, (a) flower magnified, (b) the germen and styles, (c) the fruit.

This plant is a native of the corn-fields of Southern Europe, Egypt, and Astrakan, also of the Cape of Good Hope, and the Island of Timor. It was introduced into this country about the year 1570 , and is occasionally cultivated for its fruit. It flowers in June and July.

The generic name is thought to be derived from $\alpha \_\theta \omega$ to burn, in allusion to the pungency of the seeds. Some etymologists prefer to consider $a v r, 00 v$, a radical term bestowed by the Greeks on the plant; whence the Latin anethum and other synonymes. Dill is a modern form of the Saxon bile.

Qualities and general Uses.-This plant is raised in gardens for culinary purposes, the fruit being usually imported from the south of France in large quantities for medicinal use. The leaves, flowers, and seeds, afford a useful condiment for various kinds of food; the latter are chiefly used to heighten the relish of pickles, especially cucumbers, and to adulterate British gin. The herb boiled with fish, says Gilibert, gives it an agreeable flavour, and renders it easy of digestion.

The odour of the recent herb is aromatic * and not unpleasant, but when bruised it is heavy and disagreeable: the taste is

Pallentes violas et summa papavera carpens, Narcissum et florem jungit bene olentis anethi."

Virgil, Ec. ii. 1, 46. 
sweetish, subacrid, and aromatic. The seeds* lave a more aromatic odour, and a warm pungent taste, and yield the whole of their virtues to rectified spirit. Infused in water very little of their active matter is taken up; by distillation, however, it is obtained, together with a considerable portion of essential oil.

Medicinar Properties and Uses.-Dill was held in high estimation by Dioscorides, who recommends it for augmenting the milk of nurses and to appease windy colic; he also mentions an oil prepared from the flowers as efficacious in cutting short the cold fit of intermittent fevers, and in easing sciatic and rheu-

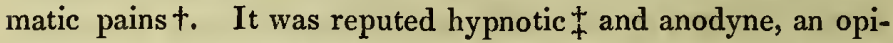
nion in which Geoffroy $\S$ appears to coincide, who observes that in this respect it resembles saffron, nutmeg, and other oily aromatics. Forestus $\|$ highly commended its effects in hiccough and vomiting, and advised the external application of the bruised herb in the form of a cataplasm. In the present day, the seeds are most frequently employed; they are considered stimulant and carminative, and are used chiefly in dyspepsia, flatulent colic, and hiccough, particularly of infants.

Of the powdered seeds, from twenty to thirty grains are considered a dose. Of the essential oil, four or five drops on sugar may be given in flatulence and hiccough.

$$
\text { DILL WATER } \Pi \text {. }
$$

Take of Dill seeds, bruised .... one pound.

Pour on them such quantity of Water, that after distillation, enough may remain to prevent empyreuma.

From one to two ounces may be given to an adult. In the flatulence and hiccough to which infants are subject, a desert spoonful occasionally proves very beneficial. It is also a useful vehicle for salts and magnesia.

* The seeds are called by the Brahmins mishi, and are frequently sold in the bazaars of Lower India for caraway seeds.-Dr. Ainslie.

+ De Mat. Med. lib. iii. c. 167, p. 201. He also thought that the tno free use of it injured the sight, " frequentiùs potum, oculos hebetat, et genituram restinguit." Ray observes, "dill has been said to be hurtful to the sight, which appears strange, since in habit and qualities it is so like fennel which, by general consent, sharpens the vision."

$\mp$ Nurses sprinkle the distilled water about the beds of the sick to induce sleep.-Bergius, l. c. p. 226.

$\S$ Mat. Med. tom. iii. p. 92.

II Opera Om. lib. vi. obs. 29.

I Aqua Anethi.-Pharm. Lond. 


\section{LXIV.}

\section{CUSCUTA EUROPAA.}

Greater Dodder.

\section{Class V. Pentandria.-Order II. Digynia.}

Nat. Ord. Convolvulaces.

Gen. Char. Calyx four or five cleft. Corolla campanulate, four or five lobed. Capsule two-celled, bursting all round transrersely at the base; cells two-seeded.

Spec. Char. Flowers sessile. Corolla destitute of scales, four or fire cleft. Stigma acute.

\section{S Y YONY MES.}

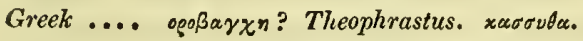

(Cuscuta major. Bauh. Pin. 217. Raï Syn. 281.

Cuscuta sive Cassutha. Ger. Em. 577.

Latin ..... $\left\{\begin{array}{l}\text { Cassutha sive Cuscutha. Fuchs. 343. c. } 132 . \\ \text { Epithymbra, Epithymum et Cassitha Plinii. Lob. Obs. } 233 .\end{array}\right.$

Androsaces, vulgo Cuscuta. Trag. 810.

(Cuscuta Europxa. Lin.Sp. Pl. 180. Fl. Brit. 282.

French.... Cuscute; Cuscute d'Europe; Groutte du lin.

Italian.... Cuscute; Androsace.

Spanish .... Cuscuta.

German.... Flachsseide; Fitzkraut.

Dutch .... Schorfte; Filtkruid; Wrange.

Swedish ... Silke.

Bohemian... Kokotice.

Polish .... Kania Przedza; Pawiliza.

Russ. .... Pawiliza.

Description.-Dodder is a parasitical plant, furnished with a fibrous root when it first springs up from the seed, but which soon perishes and leaves the plant to provide for itself. The leafless and herbaceous stems twine around flax, nettles, hemp, 
tares, hops, broom, \&c., in a direction contrary to the sun's apparent motion, sending out from their under surface small tubercles and papillæ, which insinuate themselves into the bark of the supporting plant and extract its vital juices; they are large, branched, and of a reddish colour. The flowers are nearly sessile, of a pale yellowish rose colour, collected into globose clusters. The calyx is inferior, persistent, with four, sometimes five segments. The corolla is urceolate; the limb regular, divided into four or five deep, spreading segments. The stamens are equal in number to the segments of the corolla, with erect subulate filaments, and roundish two-celled anthers. The germen is two-celled, surmounted by two short spreading styles with simple stigmas. The fruit is an elliptical capsule, twocelled, bursting transversely all round at the base; the cells usually two-seeded. The seeds contain a spiral acotyledonous embryo in the midst of fleshy albumen. Plate 16, fig. $3,(a)$ the extremity of the young shoot; $(b)$ a flower magnified; $(c)$ the same opened to show the stamens; $(d)$ the pistil; $(e)$ the fruit ; $(f)$ the same cut transversely to show the two cells, each containing two seeds; $(g)$ the seed, isolated.

This is an annual plant, parasitic on several other vegetables, as already mentioned. It is found in several counties of England, Scotland, and Ireland, though not very frequent. It flowers in August and September.

The term Cuscuta, an alteration of Cassutha, was derived

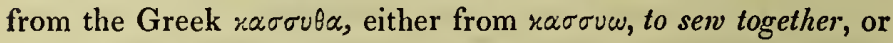
from the Arabic name of the plant, kessuth or cliessuth. Some of the ancients called it podagra lini, the gout of flax; hence the French goutte du lin. Skinner supposes Dodder to have been formed from the Dutch touteren, to shoot up. It has also received the vulgar though expressive names of Hell-weed and Devil'sguts.

There is another British species, the Lesser Dodder, (Cuscuta Epithymum,) which is smaller than the foregoing, especially in the flowers, which are usually four-cleft, and have a small fringed scale at the base of each stamen. It is generally found on thyme, heath, or furze. Eight or nine foreign species have been described. Dodder is eaten by cows, slieep, and hogs, but disliked by goats and horses. 
Qualities.-The herb is inodorous and of a slightly bitter, astringent, and acrid taste. Its sensible qualities, however, are said to vary according to the plant on which it grows. The Lesser Dodder has nearly the same properties, conjoined with a pungent aroma.

Medical Properties and Uses.-Though highly extolled by the ancients, this plant is now considered of little value as a medicine. It was thought to be detergent, incisive, aperient, and deobstruent, modified however by the nature of its fosterparent. Thus, when growing on flax, it was regarded as mucilaginous; on broom and nettle, as diuretic; on madder and bramble, as astringent. Hippocrates* employed it in phthisis, and Galen, Aetius, and Oribasius in a troop of cliseases confounded under the vague name of difficulty of breathing. Pauli, Ettmuller, and Wedel $\uparrow$, eulogized its effects in obstructions of the abdominal viscera, and by others it was recommended in intermittent fevers, while those who attributed every disease to a disordered state of the humours, fancied that it was of great service in melancholy, hypochondriasis, and other atrabiliarious affections. Haller considers it as similar in properties to Houseleek (Sempervivum tectorum).

It was given in substance, in vinous infusions or aqueous decoctions, or mixed with honey, but authors are as little agreed upon the proper dose as they are respecting the properties of the herb; Geoffroy, for instance, prescribes one, two, or three handfuls. There is this advantage, that an over-dose can do no harm.

* Lib. i. de int. affect. S. i. v. 130.

+ Ann. Mat. Med. p. 244. 


\section{LXV.}

\section{SPIRAA FILIPENDULA.}

\section{Common Dropwort.}

\section{Class XII. Icosandria.-Order II. Pentagynia.}

Nat. Ord. Rosacer.

Gen. Char. Calyx inferior, five-cleft, persistent. Petals five. Capsules three to twelve, one-celled, two-valved, few-seeded.

Spec. Char. Root tuberiferous. Leaves interruptedly pinnate; leaflets uniform, deeply cut, and serrated. Corymbs lax, paniculate.

\section{SY NONYMES.}

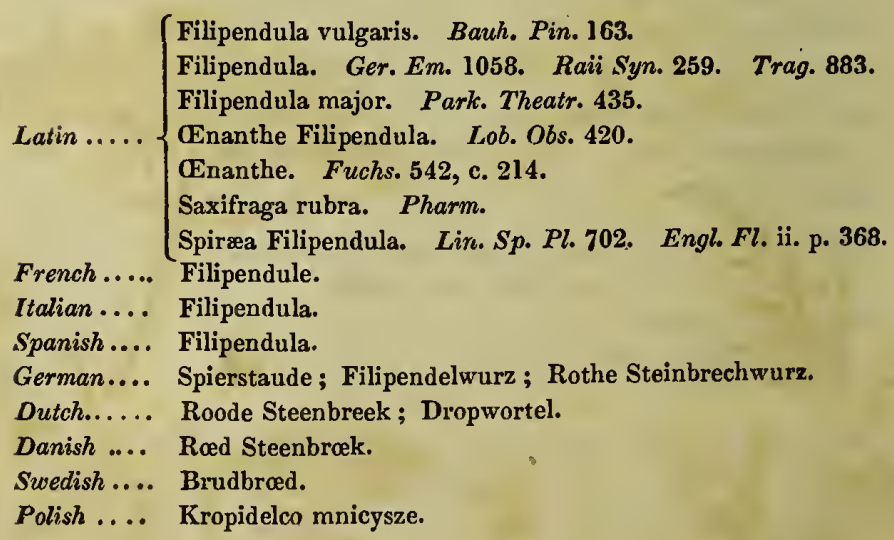

Description.-The root is perennial, cylindrical, branched, and tuberiferous; the tubers are solid oval bodies connected by solitary fibres, externally of a dark brown colour, internally 


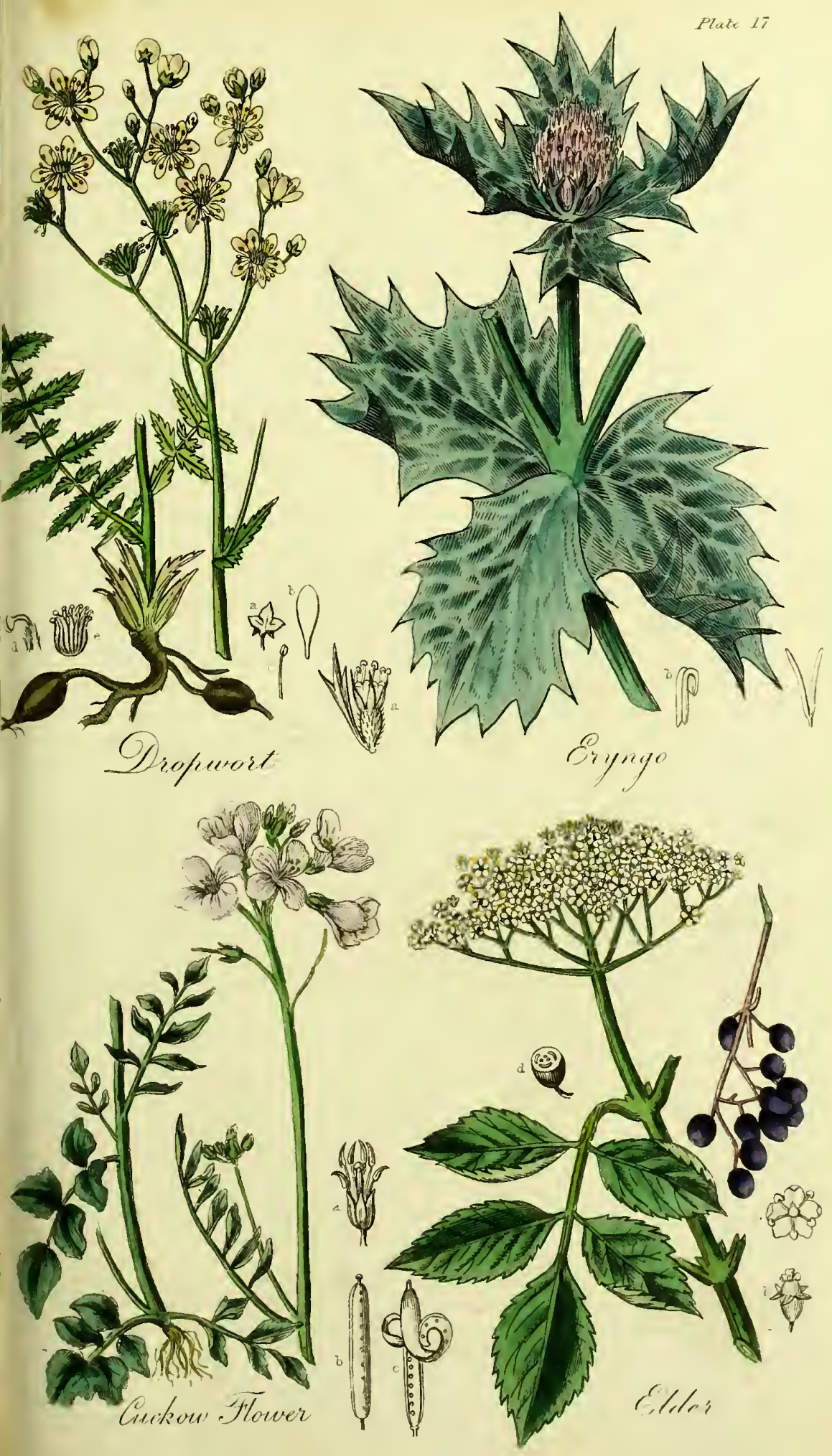



whitisl *. The stem is erect, simple, somewhat angular, smooth, and rises about a foot in height. The leaves are chiefly radical, spreading, alternate, interruptedly pinnate, bright green above, glaucous beneath; the pinnæ opposite, sessile, , lanceolate, deeply cut, and serrated; the alternate pairs much smaller, but each set uniform; the petiole is channelled above, and has at its base two amplexicaul stipulæ. The flowers are disposed in a paniculate corymb at the top of the stem. The calyx is monophyllous, inferior, five-cleft, striated, and persistent. The corolla consists of five obovate, spreading petals, of a yellowish white, tipped with rose colour. The stamens are numerous, with setaceous filaments, nearly as long as the petals, inserted into the calyx, and tipped with two-lobed anthers. The germens are five or more, superior, ovate, pilose, each surmounted by a white, reflexed style, terminated by a capitate, compressed, truncated stigma. The capsules are equal in number to the germens, elliptical, pointed, compressed, one-celled, and two-valved, containing a few small oblong seeds. Plate 17, fig. 1, (a) the calyx; (b) petal; (c) stamen; (d) pistil ; (e) capsules.

Dropwort grows in open pastures, particularly in a chalky or gravelly soil, in many parts of England, and on hills to the southwest of Artliur's Seat, Scotland. It flowers in July.

Spiræa, is the name given by Pliny to a plant whose blossoms were used for garlands, derived from $\sigma \pi \varepsilon$ a $\varepsilon$ เ $\alpha$ of Theophrastus. This species was named Filipendula, on account of its curious tubers, which are suspended as it were by threads; hence, also, the English name Dropwort. It is supposed to be the Molon of Pliny.

A variety with double flowers is cultivated in gardens. The herb is eaten by cows, sheep, goats, and swine, but refused by horses. Hogs are very fond of the roots, and are very dexterous in extirpating them from the soil.

Qualities.-The tubers, taken up late in autumn, have a plea. sant odour, resembling that of orange flowers, and a sweetish agreeable taste, similar to hazel-nuts, combined with a slight bitterness. In spring they are bitter, and less fragrant. The

- These singular oroid lumps appear to be designed as reservoirs of nourishment to the plant, enabling it to resist drought, its usual habitat being dry gravelly pastures. 
flowers and the recent herb have a bitterish taste and an aromatic smell.

In autumn, if the recent tubers are scraped and well washed in cold water, they afford a fragrant, dark red tincture, which, left to itself, soon deposits a white, friable, amylaceous fæcula. This fæcula, or starch, is possessed of nutritive qualities*, and by decoction in water, affords a jelly-like, glutinous substance. The fresh flowers boiled in milk impart an agreeable flavour, and a fragrant distilled water may be made from them. The dried herb has been used in tanning leather.

The dried tubers are rather bitter and astringent. The aqueous infusion has the same flavour as the plant, and becomes of a reddish colour, which is rendered black by sulphate of iron.

Medical Properties and Uses.-In Dropivort, we have to record the fate of another plant which has sunk into oblivion. It was esteemed by the ancients as incisive, diuretic, and lithontriptic. Sennertus, as quoted by Ettmuller $\psi$, recommended a decoction of it combined with butchers'-broom and figwort, to be administered in scrofula. Simon Pauli + gave it in fluor albus, Lobel in epilepsy, and J. Bauhin, on the authority of Cæsalpinus, states that the distilled water of the plant was reckoned an antidote against the plague. A more probable account is given by some, of its effects in dysentery, in which disease, fifteen grains of the powdered root were given every four hours with success. Modern practitioners have either neglected it, or have omitted to record their experience of its properties.

It was employed in the form of decoction, by boiling an ounce of the dried root $\oint$ in a pint and a half of water, to a pint; and a vinous tincture was prepared with three ounces of the bruised root in a quart of white wine.

* In times of scarcity the tubers have been used for food.-Linn. Flora Suecica, p. 439. Dried and reduced to powder they afford a substitute for bread not to be despised.-Ibid. Aman. Acad.

† Op Med. ed. J. C. Westphali, tom, i. p. 569.

‡ Bot. Quadripart, p. 332 .

$\S$ More correctly the iubers. 


\section{LXVI.}

\section{SAMBUCUS NIGRA. \\ Common Elder.}

Class V. Pentandria.-Order III. 'Trigynia.

Nat. Ord. Caprifoliacer.

Gen. Char. Calyx five-cleft. Corolla rotate-urceolate, five-cleft. Berry inferior, sub-globose, three or four seeded.

Spec. Char. Cymes with five principal branches. Leallets ovate. Stipulæ obsolete. Stem arboreous.

\section{SYNONYMES.}

Greek..... ахт». Dioscorides.

Sambucus fructu in umbella nigro. Bauh. Pin. 456.

Sambucus. Ger. Em. 1422. Raii Syn. 461. Dod.832. Trag. 997. Fuchs. 64. c. 20.

Latin ..... Sambucus vulgaris. Park Thealr. 208. Lam. Fl. Fr. iii. p. 369.

Sambucus nigra. Lin. Sp. Pl. 335. Fl. Brit. 336. Eng. Bot. t. 476 .

French.... Sureau; Sureau commun; Sureau noir.

Ilalian.... Sambuco; Sambugaro.

Spanish ... Sauco.

Portuguese. Sabugueiro.

German .. Hohlunder; Hollunder; Holunderbaum; Holder; Flieder.

Dulch .... Vlierboom.

Danish.... Hyld.

Swedish .. Floeder.

Bohcmian. . Bez.

Polish .... Bzowy.

Russ. .... Busina.

Lithuanian. Pluschu kohks.

Arabic.... Ukti; Khaman.

Chinese... U.chu-yu. 
Description. - Common Elder is a sniall tree, attaining the height of twelve to twenty feet, covered with a rough ash coloured bark; the wood is smooth and white; the young branches are opposite, green, fistulous, and filled with a white spongy pith. The leaves are opposite, petiolate, pinnated, smooth, and of a deep green colour; the pinnæ usually five, ovate, lanceolate, acute, serrated, the terminal one the largest ; footstalks angular, channelled. The flowers are numerous, small, white, or cream coloured, disposed in large terminal cymes, with five principal branches, and many secondary ones. The calyx is superior, permanent, very small, five-cleft, and smooth. The corolla is rotate, slightly concave, with five deep obtuse segments. The stamens are five, with subulate filaments about as long as the corolla, into the throat of which they are inserted, terminated by yellow, cordate, two-celled anthers. The germen is inferior, ovate, smooth, without a style, but supporting three roundish, obtuse stigmas. The berries are succulent, globose, purplishblack when ripe, one-celled, containing three or four linearovate, plano-convex seeds. Plate 17, fig. 4, (a) corolla; (b) calyx, germen, and stigmas ; $(c)$ the fruit ; $(d)$ berry cut transversely.

Elder is a well-known tree, frequent in hedges, woods, and coppices in this country. It is found in similar situations throughout Europe, the Caucasus, Siberia, and Japan. It flowers in $\mathrm{June}$, and ripens its berries in September.

Sambucus is so called from $\sigma \alpha \mu B u \times r$, sambuca, a musical instrument, probably the sackbut, in the construction of which the wood of this tree is said to have been employed. Elder is derived from the Saxon ellara; it is sometimes called Boor-tree in the north.

There are three or four varieties which are seldom found wild, but are cultivated in shrubberies and gardens. The chief of these are, the laciniated (Sambucus nigra laciniata), the leaves of which are variously incised; and the white-berried ( $S$. leucocarpa) which has more fragrant flowers than the common kind, and the berries larger, white or greenish-white, and more agreeably flavoured for domestic purposes.

Economicar Uses. - The wood being hard and tough is made into skewers, tops for angling rods, and needles for weaving nets; it is also employed by turners and cabinet-makers. 'The branclies 
fnrnish tubes for various purposes, and the light pith they contain is much used in electrical experiments, and for fancy ornaments. The leaves are said to drive away moles if spread about their haunts, and an infusion of the same proves fatal to insects that infest delicate and blighted plants. The flowers, especially those of the white-berried kind, give to wine the odour of muscat, and are often used to simulate Frontignac wines, and to flavour vinegar. The French put layers of them among apples, to which they communicate a very agreeable odour. A cordial domestic wine is often made in the country with the berries, a considerable portion of sugar and spice being employed. This wine, though made in autumn, is ready for use the following winter, and is usually taken warm. In Germany, a strong spirit is distilled from the fruit; especially after it has been sweetened by night frosts. It is said to be used also in the adulteration of port wine. Lastly, Dambourney observes, that linen may be dyed of a brown colour with the juice of these berries, and that wool previously treated with bismuth, acquires a beautiful blueish-grey, which is very permanent.

According to Linnæus, the leaves are refused by all aninals except sheep, to which they are said to be very beneficial when affected by the disease called rot; but others assert that cows eat them eagerly. The flowers prove fatal to turkeys, and the berries are reputed to be poisonous to poultry, though eaten by many small birds.

Qualitres. - The whole plant has an unpleasant narcotic smell, and some authors have asserted that it is dangerous to sleep under its shade*. The inner bark is of a fine green colour, inodorous, sweetish to the taste at first, subsequently bitter, acrid, and nauseous. The leaves have a disagreeable odour, very fetid when bruised, and a nauseous taste. The recent flowers have a fragrant smell, which soon becomes faint and heavy; the odour of the dried flowers is rather more powerful.

By distillation in water the flowers impart their aroma and active qualities, and a small portion of essential oil separates. Infusion in water or alcohol, likewise extracts their virtues. The seeds yield by expression about an eighth part of dense, grecn- 
ish oil. The berries are inodorous, acidulous, and sweetish; they contain saccharine matter, jelly, and malic acid; and their deep purple juice is as delicate a test of the presence of alkalies and acids as litmus paper*

Medical Properties and Uses.--If the Elder be, as is generally supposed, the $a x \gamma \eta$ of the Greeks, we find it mentioned by Dioscorides + , Theophrastus, and Galen. Hippocrates $\ddagger$ used it as a purgative in dropsies and other diseases; and from his time to the present, it has enjoyed more or less celebrity. According to Dr. Ainslie, the Arabians and Syrians of the present day are well acquainted with it. To begin with the flowers : -These when recent are slightly purgative and resolvent, but in their dried state they appear to act by the cutaneous exhalants and provoke perspiration, and are hence consiclered diaphoretic and sudorific. With this view, an infusion of them sweetened with sugar, has been regarded as very useful at the onset of pulmonary catarrhs, coryza, sore throat, and other affections arising from suppressed perspiration. It has also been employed in the latter stage of bronchial catarrh and pulmonary affections, where there is no fever, heat, or thirst; and has been highly extolled in small-pox, measles, scarlatina, and other eruptive diseases which have been accidentally checked in their determination to the skin. Externally, the flowers have been employed either in infusion or cataplasm, to resolve inflammatory and œdematous swellings.

The berries are considered aperient, and sliglitly excitant and sudorific, and have been ordered in rheumatism, erysipelas, and febrile diseases. When dried they were formerly, but $\mathrm{cr}$ roneously, called grana actes. The seeds are laxative.

The bark and leaves are the most powerful parts of the plant. They excite purging and vomiting in a large dose, and in some instances have produced hypercatharsis $\$$. The inner bark has been extolled as an excellent hydragogue purgative, and in small doses as deobstruent. Sydenham $\|$ and Boerhave $\$$ speak of its

* Chevalier, in Journ. de Pharm. Avril, 1820.

† De Mat. Med. lil. iv. c. 174, p. 313.

$\ddagger$ De morbis, lib. ii. p. 468.

§ Vide Barthol. Act. LIafn. vol. i. p. 164, et Eph. nat. cur. Dec. 2, ann. 3, p. 48.

II Opera, p. 496.

9ा Hist. Plunt t. i. p. 207 . 
good effects in dropsy and in various chronic affections. The former directs three landfuls of it to be boiled in a quart of milk and water till only a pint remains, of which one half is to be taken night and morning, and repeated for several days. Boerhaave gave its expressed juice in doses from a drachm to half an ounce. Others have recommended an infusion of half an ounce of the fresh bark in wine, to be taken at one dose and repeated.

A singular fungus is sometimes found growing on the trunk of the common Elder, called Judas' ear, (Exidia Auricula $J u d a *$, ) from its resemblance to the human ear. It was once used medicinally as an astringent, and employed in infusion or decoction; also in the form of a lotion in ophthalmia, and as a gargle in sore throats accompanied with relaxation.

Several preparations beside the decoction and infusion of Elder have been recommended; the most useful of which are ;

$$
\text { ELDER ROB } \psi \text {. }
$$

Take of ripe Elder-berries....... five parts;

Sugar.............. one part.

Boil with a gentle heat to the consistence of a thick honey.

This is prescribed as a diaphoretic, in the dose of an ounce and a half to two ounces, in febrile disease, and in acute rheumatic affections; likewise made into a gargle for sore throats.

\section{ELDER VINEGAR.}

Take of dried flowers of Elder...... one part;

Vinegar .............. twelve parts.

Macerate for four days, clarify with milk and filter.

Given in sugared water to promote perspiration; or mixed with honey and water as a gargle.

ELDER-FLOWER WATER.

Take of Elder-flowers......... three parts;

Water ........... a sufficient quantity.

Distil six parts.

This is esteemed slightly diaphoretic and anodyne, and forms a plcasant vehicle for other medicines.

- Peziza Auricula. - Linn.

+ Succus spissatus sambuci nigri,-H'larm. Edin. cl Dubl. 


\section{ELDER OINTMENT*}

Take of Elder flowers.......... one pound ;

Prepared lard $\ldots \ldots \ldots$ one pound.

Boil the elder-flowers in the lard until they become crisp, then strain the ointment through a linen cloth. An ointment may be made with the leaves in the same manner.

This is a useful emollient application to benign ulcers, \&c.

There is another British species, the Dwarf Elder or Danewort, (Sambucus Ebulus, ) occurring in waste places and by waysides, flowering in July. It may be easily discriminated from the above by its low herbaceous stem, lanceolate leaflets, foliaceous stipulæ, cymes with three principal branches, and purplish flowers. It is more purgative in all its parts than the common Elder; the inner bark is powerfully drastic and emetic, and has sometimes produced dangerous effects. Its sudorific and diuretic properties are likewise more evident.

- Unguentum Sambuci._Pharm. Lond. et Dubl. 


\section{LXVII.}

\section{INULA HELENIUM.}

Elecampane.

\section{Cless XIX. Syngenesia.-Order II. Polygamia Superflua.}

Nat. Ord. Composite.

Gen. Char. Involucre imbricated; scales spreading, outer ones foliaceous. Anthers with bristles at the base. Receptacle naked. Pappus simple. Flowers yellow.

SPEc. Char. Leaves orate, amplexicaul, somewhat toothed, wrinkled, downy beneath. Scales of the involucre ovate, downy.

S Y NON Y M E S.

Greek..... เ is issov.

Helenium vulgare. Bauh. Pin. 276.

Helenium. Ger. Em. 793. Raii Syn. 176. Cam. Epit. 35.

Aster omnium maximus, Helenium dictus. Tourn. Paris. 396.

Latin .... Flenium sive Enula campana. Fuchs. 242.

Elenion. Trag. 170.

Inula Helenium. Lin. Sp. Pl. 1236. Fl. Brit. 891. Eng. Bot. t. 1546.

French.... Aunée; Enule campane; Inule aunée.

Italian... Enula campana ; Elenio.

Spanishand

Portuguese. $\}$ Enula campana.

German.... Alant ; Alantwurzel; Brustaland; Helenenkraut.

Dutch..... Alant; Alantkruid.

Danish ... Oland Sanct Ellensron.

Swedish.... Aland.

Bohemian.. Wowen.

Polish.... Omanowy.

Huss ...... Dewjatschik.

Persian.... Bekhizanjabilischami.

Arabic...... Usululrasun. 
Description.-The root is perennial, thick, fleshy, branched, brown or yellowish externally, and white within. The stem is upright, firm, round, striated, branched, downy, and rises to the height of four or five feet. The radical leaves are large, often a foot long, petiolate, ovate-lanceolate, toothed, wrinkled, traversed by many reticulated veins, of a deep green colour above, whitish and cottony beneath; the cauline leaves are smaller, more acutely pointed, and sessile; both kinds are alternate. The flowers are large, terminal, solitary, radiated, and of a golden yellow colour. The involucre is composed of several large, ovate, imbricated, downy scales, of which the exterior are leafy. The florets of the ray are long, narrow, spreading, tricuspidate, and pistilliferous; those of the disk are numerous, perfect, tubular, with a five-cleft limb. The anthers are united into a cylindrical tube, with five acute teeth above, and ten bristles at the base. The germen is oblong, with a filiform cloven style and a bifid obtuse stigma. The fruit is linear, quadrangular, and striated, with a simple sessile pappus. The receptacle is nearly flat, naked, or slightly scaly. Plate 16, fig. $4,(a)$ floret of the centre or disk; (b) floret of the circumference or ray; $(c)$ anthers, united into a tube; $(d)$ summit of the style magnified.

Elecampane is a native of moist meadows and pastures, generally near houses. Though it is rather local, it is not uncommon in the south and west of England, Ireland, and Scotland. It is also indigenous to France, Italy, Germany, Spain, Sweden, \&c. It flowers in July and August.

The generic name Inula, is said to be an alteration of $\varepsilon \lambda \varepsilon v b s \nu$, Helenium, which, according to the brilliant fancy of the ancients, sprang from the tears of the renowned Helen. The common name, Elecampane, is a corruption of the old Latin term for the plant, Enula campana*. It is well described by Dioscoridest, and some imagine that the Panax Chironium of Theophrastus \& refers to this plant. Horace alludes to it more than once:-

"Erucas virides, inulas ego primus amaras

Monstravi incoquere."-Sal. 8. l. 51 .

* Enula campana reddit præcordia sana.-Schola Salern. c. 40, p. 457.

+ De Mat. Med. lib. i. c. 27, p. 22.

+ Hist. lib. ix. c. 10 . 
"cum rapula plenus

A tque acidas mavult inulas."-Sat. 2. $l$. 44.

Qualities and general Uses.-Elecampane is sometimes cultivated for the sake of its flowers, but it is not of any utility in pastures; goats and horses, however, sometimes eat it in the absence of better food. The roots, when bruised and macerated in wine with balls of ashes and whortle-berries, will dye stuffs of a blue colour.

The recent root exhales a strong, penetrating odour. When dried, the smell is aromatic yet slightly fetid, and on clewing it, the taste is at first disagreeable and glutinous, then bitterish, hot, and pungent. Both alcohol and water extract its virtues, the former most completely. By chemical analysis, the root affords a volatile oil which easily concretes, extractive matter, resin, vegetable albumen, acetic acid, and principally a kind of greyish, odorous fæcula, discovered by M. Rose*, and named by Dr. Thomson, Inulin $\uparrow$.

Medical Properties and Uses.-The root of Elecampane was much esteemed by our ancestors as a valuable drug. Hippocrates and Galen make favourable mention of it. Dioscorides speaks of its efficacy in sciatic affections. It has been strongly recommended in pectoral affections ${ }_{+}^{+}$, particularly in coughs and asthmas; and besides promoting expectoration, it is also said to act as a sudorific and diuretic. Its diuretic properties, however, Cullen $\S$ considers as trifling, and could not discover that it possessed any expectorant virtues, It is reputed a good remedy in complaints of the stomach arising from acidity; hence its value in dyspepsia and those colics so frequently originating in the acidity of that organ. It is found a powerful remedy in that kind of imperfect paralysis to which the ancients gave the name of Parcesis, in

- Annales de chimie, tom. lxxvi. p. 98.

+ This substance is characterised by its forming a resinous matter when submitted to the action of acids, a phenomenon which takes place with $\mathrm{no}$ other frecula. It yields on distillation in a retort all the products furnished by gum. Dissolved in hot water it renders the liquid mucilaginous, and precipitates on cooling in the form of a white powder. Inulin may be obtained by boiling the root in four times its weight of water and leaving the liquid in repose.

+ Delue in Crell's Chem. Journ.

§ Mat. Med. rol. ii. p. 459. 
which the power of the muscles of the limbs is greatly weakened, but not destroyed; as also in that species of paralysis which is the result of the Colica Pictonum, or painter's colic. This complaint is very frequent in Austria and Moravia, where they attribute it to the acid wines of those countries, though more probably it is owing to the leaden cisterns and vessels in which it is occasionally kept. The Elecampane is considered by the inhabitants as a specific for these paralytic affections.

Ettmuller strenuously commends its use in all scorbutic affections, and in gout and rheumatism, where that diathesis prevails. He praises it, also, in venereal affections where mercury is employed, for the sake of counteracting the pernicious effects of that mineral upon the constitution, or for the purpose of removing them when they have taken place.

With the same view Hermann* prescribed it. Uterine influence is also attributed to it $\uparrow$; hence its employment to promote menstruation and for the cure of chlorosis + . As to its remedial agency against the plague, opinions are divided, Diemerbrœck $\S$ and Ray $\|$ advocate it, while otliers have no faith in its power.

Externally, Elecampane, either in the form of an ointment or in decoction, has been employed for the itch, but sulphur and other mineral productions are much more to be depended on.

The dose of this powdered root is from a drachm to two

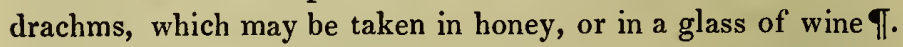

The British Pharmacopœias do not direct any simple formula, but merely introduce Elecampane as an ingredient in a confection of pepper**; but our continental neighbours are somewhat profuse in their recipes.

- Herm. Cynos. Mat. Med. t. i. p. 47.

+ Dioscorides, loco cit.

$\ddagger$ Murray, Mat. Med. t. i. p. 230.

§ Diem. de Peste, p. 157.

|| Ray, Hist. Plant. t. i. p. 47.

I The fresh root is sometimes prepared by the confectioners as a candy, in which form it may be taken to advantage from half an ounce to an ounce at a time; or a decoction may be made of it, so that the same quantity be taken at a dose.

- Confectio Piperis Nigri.-Pharm. Lond. 


\section{DECOCTION OF ELECAMPANE* *}

Take of Root of Elecampane, half an ounce;

Spring water,...... sufficient

to affiord after ebullition six ounces of fluid.

Dose, one or two table-spoonfuls every two hours.

$$
\text { TINCTURE OF ElEcampane } \nmid \text {. }
$$

Take of Root of Elecampane, one part ;

Alcohol ............ six parts.

After digesting the root in a gentle heat, filter.

Exciting, carminative and diaphoretic. Dose, ten drops to a drachm.

$$
\text { SYRUP OF ELECAMPANE }+ \text {. }
$$

Depurated juice of the root, one pound and a half; White sugar .......... two pounds and a half.

Dissolve the sugar in the juice and strain.

- Decoctum Helenii.-Pharm. Batav. ed. Niemann.

+ Tinctura Helenii.-Pharm. Austriaca, 1821.

‡ Syrupus Enulæ.-Pharm. Wirtem. 


\section{LXVIII.}

\section{ULMUS CAMPESTRIS.}

Common small-leaved Elm.

Class V. Penntandria.-Order II. Digynia.

Nat. Ord. Ulmaces.

Gen. Char. Perianth single, superior, four or five cleft, persistent. Capsule a samara, closed, membranous, compressed, margined, superior, one-seeded.

Spec. Char. Leaves thomboid-ovate, acuminate, oblique at the base, doubly serrate, scabrous above, downy beneath. Branches wiry, somewhat corky, pubescent when young. Fruit oblong, cloven, naked.

\section{S Y N O N Y M S.}

Greek......

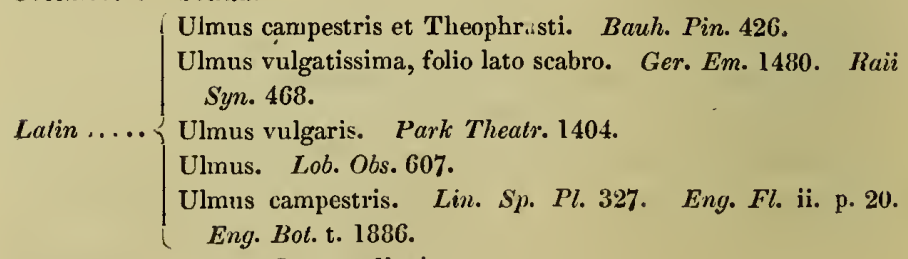

French.... Orme; Orme ordinaire.

Italian ... Ormo.

Spanish and ? Olmo.

Portuguese

German... Ulme ; Ulmbaum ; Rüster.

Dutch..... Olm ; Olmboom; Ypenboom ; Herseleer.

Danish and $\}$ Alm.

Polish .... Ilm; Kora wiazowa.

Russ. .... Ilim.

Turkish .. Kasagatsch. 


$$
\text { . }
$$




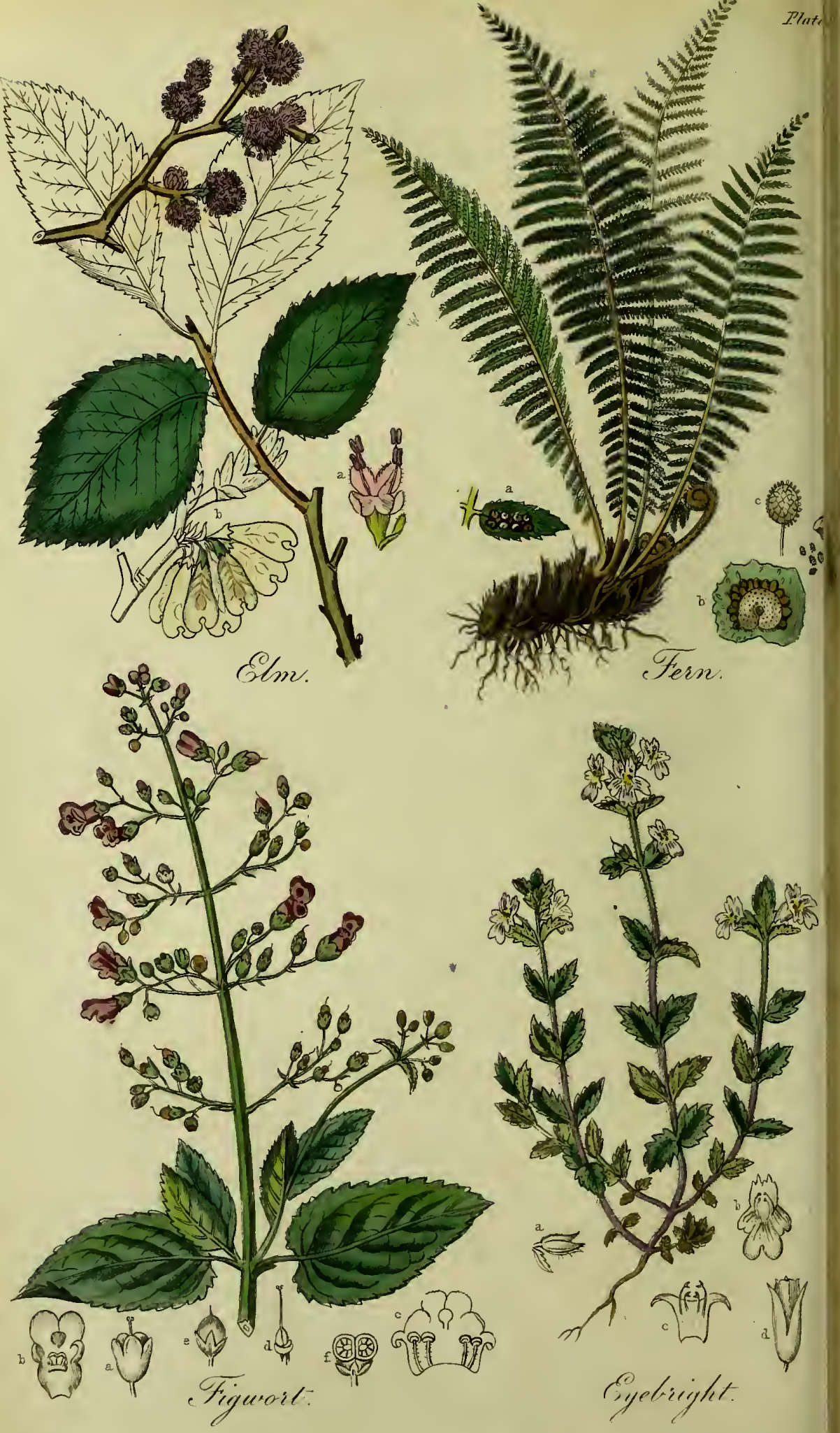


Description.-Common Elm is a lofty tree, sending off strong, spreading, lateral branches; when young, covered with a smooth, very tough bark, becoming rugged by age; heartwood yellowish brown. The leaves are alternate, ovate, approaching to rhomboid, acuminate, rough above, downy beneath, doubly and irregularly serrated, from one to three inches long, and of a dark green colour. The flowers, which appear before the leaves, are produced from distinct buds, in numerous dense leads, each subtended by a small scale or bractea. The perianth (calyx) is four-cleft, persistent, fringed, of a light red or brownish colour. The four stamens are equal, smooth, longer than the perianth, with large, roundish, purple, two-lobed anthers. The germen is oblong, compressed, cleft, supporting two spreading styles, each terminated by a stigma, which is fringed on the upper edge, and ultimately dilated at the lower. The capsule (a Samara) is membranous, compressed, winged all round, indehiscent, and containing a single roundish seed. Plate 18, fig. 1, (a) the perianth and stamens magnified; $(b)$ the fruit.

This is a tall, elegant tree, common in scattered woods and hedge-rows, principally of the southern counties of England. It is also a native of Barbary and Palestine, whence Dr. Walker thinks it was introduced into this country by the crusaders. The flowers appear in March and $\Lambda$ pril, and the fruit ripens in June.

The name Ulmus is derived from the Anglo-Saxon elm,-its exact appellation also in 'Teutonic, Gothic, and nearly all the Celtic dialects.

There are six other species considered indigenous to Britain, the chief of which are the Smooth-leaved Elm (U. glabra), with ovate-lanceolate smooth leaves; the Cork-barked Elm ( $U$. suberosa), distinguished by the cork-like covering of its branches; and the Wych Llm (U. montuna), easily recognized by its large, spreading branches, and broad leaves appearing just as the hop-like fruit comes to perfection *.

The Elm was well known to the ancients; and that it was prized for its economical uses is sufficiently obvious from the writings of Virgil and others, but they do not appear to have

"See "Hooker's British Flora" and "Lindley's Synopsis." 
discovered in it any medicinal virtues. The Mantuan bard gives ample directions, ulmis adjungere vites, it being usual in those days to fasten the weak and limber vine to the sturdy EIm*. Later poets have some happy allusions to this practice: thus our own Milton, describing the morning avocations of the dwellers in Eden :-

\section{—_ "They led the vine}

To wed her elm; she spoused about him twines

Her marriageable arms, and with her brings

Her dower, th' adopted clusters, to adorn

His barren leaves."

Paradise Lost, b. v. 1. 216.

6" Thou art an elm, my husband, I a vine,

Whose weakness married to thy stronger state,

Makes me with thy strength to communicate."

\section{Shakspeare.}

In the Teutonic mythology the Elm had the honour of being chosen for the formation of the first woman, Emla (elm), as the first man was Aske (ash). Several superstitious customs were practised by our Saxon ancestors on this tree. A canon of Edgar in the tenth century runs thus: "We decree that every priest shall anxiously advance Christianity, and forbid tree worship, divination with the dead, omens, charms with songs, and many other illusions which are practised in asylums on Elms (hence, perhaps, the name $W_{y}$ tch Elm) and on various other trees, by which many are perverted who ought not to be so."

Qualities and general Uses. - This beautiful tree is well adapted for planting, as it does not destroy the grass beneath it. Animals in general are very fond of the foliage, and eat it greedily. The wood is much valued; being hard and tough, it is used for making axle-trees, mill-wheels, keels of boats, chairs, \&c.; and being very durable in wet situations, it is preferred for coffins. It is also stained to imitate mahogany. The tree is much infested by insects, especially the aphis ulmi, which feeds upon the juices of the leaves and makes them curl, to form, as is supposed, a shelter from the weather. Silkworms are fond of the leaves. Dambourney obtained from the bark a yellowish-brown colour for dyeing, and De Vilette manufactured of it a kind of strong brown paper.

* He has also given the Elm a place in the infernal shades. Vide $A n$. lib. vi. v. 283. 
The inner part of the bark of the young branches is the part used medicinally. This bark is of a brownish red colour and inodorous; it has a slightly bitter, astringent taste, and on being chewed, proves mucilaginous. When boiled in a small quantity of water, it forms a thick, dark brown coloured decoction, which gelatinizes as it cools, and when evaporated leaves a brittle, semi-transparent substance, soluble in water, but insoluble in alcohol and ether, to which, however, it imparts a brownish colour. The brittle residue, when treated in the same manner as Klaproth treated the gum-like exudation* from the Ulmus nigra, afforded nearly the same results; consequently it must be regarded as ulmin $\uparrow$.

Medicinal Properties and Uses. - The root, leaves, and bark of this tree were formerly used in medicine, on account of their astringent and detersive qualities. In modern practice, a decoction of the inner bark has been highly recommended in some cutaneous affections allied to tetter and leprosy. Dr. Lysson + mentions five cases of inveterate eruptions, which were successfully treated by a decoction of elm bark, but as he added nitre to it, and also frequently had recourse to purgatives, Woodville $\S$ questions if these cures ought to be wholly ascribed to the bark. Dr. Lettsom $\|$ attributes the cure of a severe case of lepra ichthyosis of Sauvages, in which other remedies had failed, to the use of elm. Banau I, in particular, mentions an instance of common leprosy affecting the whole body, in which it was successful. Many other practitioners have commended it in cutaneous complaints, but Willan** and Banau $+\nmid$ also recommend it in herpetic complaints generally, in flying and fixed pains, old ulcers, fluor albus, cancerous, scrofulous, and nervous affections, obstinate rheumatism, scurvy, scald-head, \&c. Prout +ł used this medicine in various skin

* This substance has been named Ulmin from the tree which produces it. According to Berzelius, it exists in the bark of many other trees.

+ Thomson's Dispensatory, p. 656.

‡ Medical Transactions, vol. ii. p. 203.

\$ Med. Bot. vol. iv. p. 711 .

II Medical Memoirs, p. 152.

T Journ. de Paris, 1783, n. 255.

* Descrip. Cut. Dis. vol. i. p. 139.

t† Murray, Mat. Med. t. iv. p. 606.

㛣 Modern Pract. Lond. Hosp. p. 113. 
affections, and also as a gargle in ulcerations of the mouth. Jeffreys* esteems it a good substitute for sarsaparilla, and he mentions several cases illustrative of its efficacy; likewise for cinchona bark. Ray prescribed a decoction of the bark reduced to the consistence of a syrup, after which a third part of brandy was added. This he extolled as a valuable remedy against sciatic pains, to be applied as a fomentation, near the fire, for some time together. The slimy juice which abounds in the inner bark, has been recommended in affections of the kidneys, and externally as a useful application to burns.

The British colleges give the following formula for a decoction.

$$
\text { DECOCTION OF ELM } \dagger \text {. }
$$

Take of fresh Elm bark, bruised, four ounces ;

Water ............. four pints.

Boil to two pints and strain.

The dose is from four to six ounces, taken twice or thrice a day.

$$
\text { INFUSION OF ELM } \ddagger \text {. }
$$

Take of fresh Elm bark ........ one ounce;

Boiling water......... one pint.

Infuse in a covered vessel for two hours, and pour off the clear liquor.

- Cases in Surgery, \&c. p. 194.

+ Decoctum Ulmi, Pharm. Lond., Dub.

¥ Infusum Ulmi, Pharm. Amer., \&o. 


\section{LXIX.}

\section{ERYNGIUM MARITIMUM.}

Sea Eryngo, or Sea Holly.

\section{Class V. Pentandria.-Order II. Digynia.}

\section{Nat. Ord. Umbellifere.}

Gen. Char. Calyx of five lobes, leafy. Petals erect, connivent, oblong, with long, inflected points. Fruit subterete, obovate. Carpels covered with chaffy scales, and destitute of ridges and vittæ, semiterete.-Flowers collected into roundish heads. Involucres of many leaves.

Spec. Char. Leaves whitish, glaucous, coriaceous; those of the root with long petioles, roundish, cordate, plaited, spinous; upper ones amplexicaul, palmate, lobed. Involucres of five to seven leaves, longer than the heads; scales three-cleft.

\section{S Y NON Y M E S.}

Greek .... เ เ purgioy.

(Eryngium marinum. Ger. Em. 1162 Raii Syn. 222. Cam. Epit. 448. Dod. 718. Clus. Hist. ji. 179. Latin .... $\begin{aligned} & \text { Eryngium marinum, Drypis Theophrasti quorundam, Loh. } \\ & \text { ic. ii. } 21 \text {. }\end{aligned}$

Eryngium maritimum. Bau\%. Pin. 386. Lin. Sp. Pl.337.

( Fl. Brit. 218. Eng. Bot. t. 718.

French.... Panicaut; Panicaut maritime.

Italian.... Eringio marino.

Sparish.... Cardo marino.

German .. Meersmannstreu ; Meerstrandmannstreu.

Dutch ... . Zee-krius.distel ; Meerdistel.

Danish.... Strandmandstrœ.

Swedish... Blœ ; Sjotistel.

Russ..... Sinaja golownik. 
Description.-The root is perennial, long, creeping, cylindrical, whitish internally, and covered with a brown epidermis. The stem is cylindrical, thick, striated, branched, leafy, sinooth, glaucous, and attains the height of twelve inches or more. The radical leaves are roundish-cordate, stalked, plaited; the upper ones are sessile, lobed, palmated, amplexicaul; the whole smooth, glaucous, ribbed, veiny, and toothed with sharp spines. The flowers are disposed in dense terminal, roundish heads (resembling at first sight a syngenesious plant). The involucre consists of five to seven rigid leaves, longer than the heads. A single bractea or scale, which is three-cleft, spinous, and rather longer than the calyx, accompanies each fioret. The calyx has a rough, scaly tube, and a leafy, five-lobed limb. The corollas are of a light purplish-blue colour, and composed of five erect, oblong petals, inflexed at the points. The five stamens are furnished with capillary filaments tipped with roundish, oblong anthers. The germen is inferior, oblong, clothed with erect bristles, and terminated by two filiform, nearly erect styles, with simple stigmas. The fruit is obovate, subterete, separable into two carpels, which are covered with chaffy scales, and destitute both of ridges and vittæ; each carpel containing an oblong, nearly cylindrical seed. Plate 17, fig. 2, (a) floret magnified, showing the three-cleft bractea, calyx, petals, and stamens ; $(b)$ a single petal; $(c)$ the styles.

This plant is very frequent on sandy sea-shores throughout Europe, flowering in July and August.

The term Eryngium was given to this genus because it was supposed to include the epvyylov* of Dioscorides and the Erynge or Eryngion of Pliny $\dagger$; and hence the English name. This species has also been designated Sea Hulver, Sea Holm, and Sea Holly, on account of its spiny leaves.

There is one other British species, the Field Eryngo, (Eryngium campestre, distinguished by its pinnatifid leaves, and the undivided scales or bracteæ of the receptacle. It is far less common than the Sea Eryngo, but its properties are similar.

QUalities and general Uses.-The root is candied and. 
eaten as a sweetmeat; the more in request because of its supposed restorative and stimulant qualities, and for which it was much celebrated in the days of Shakspeare*. Eryngo roots were first candied at Colchester, about the beginning of the seventeenth century, by Robert Burton, apothecary $\uparrow$. Ample directions how to "condite Eringos" are given by Gerard *. According to Linnæus, the young shoots prepared like asparagus are grateful to the taste, and very nutritious and restorative. The roots have a sweet agreeable taste, and an aromatic odour which they yield completely to water. They appear very similar in qualities to the Angelica root. The aqueous infusion after it has stood a while becomes slightly mucilaginous, but its constituent principles have not been examined.

Medicinal Properties and Uses.-The root, or rather the bark of the root, is the part used in medicine. Dioscorides $\S$, with other of the ancients, considered it a valuable promoter of the menses when obstructed, and also administered it in tormina, liver-complaints, and other disorders. Boerhaave esteemed it the principal of the aperient roots, and he usually prescribed it as a diuretic and antiscorbutic \|; but by later practitioners its aperient properties are esteemed as, very gentle, calculatcd, indeed, only as an adjunct to the aperient decoctions intended for delicate or pregnant females. Ettmuller, Geoffroy, and most of the ancient writers, speak of this medicine as a certain though gentle aphrodisiac. It is principally, however, in affections of the chest, that it has been employed with success; and even in consumption it has been found greatly to relieve the cough and promote an easy expectoration. For this purpose the candied root is the most pleasant and the best form, as all the virtues of the root are preserved by the sugar. Ettmuller recommends a conserve of it with the same intentions; and this is worth keeping, as it admits of combination with other medicines.

* Thus Falstaff exclaims, "Let the sky hail kissing-comfits and snow eringoes."-Merry Wives of Windsor, Act v. Sc. 5 .

+ Morant's Colchester, p. 92.

¥ Herbal, ed. Johnson, p. 1163.

$\S$ Lib. iii. c. 24 .

|| Boerh. Hist. Plant. t. i. p. 194. 


\section{LXX. \\ EUPHRASIA OFFICINALIS.}

Common Eyebright.

Class XIV. Didnnamia.-Order II. Angiosfermia.

Nat. Ord. Scrophularinere.

Gen. Char. Caly $x$ tubular, four-cleft. Corolla two-lipped; the upper lip dirided; the lower one of three nearly equal lobes. Cells of the lower anthers spurred at the base. Capsule ovate-oblong, two-celled. Seeds striated.

Spec. Char. Leares orate, deeply toothed. Segments of the lower lip of the corolla emarginate.

SY NONYMES.

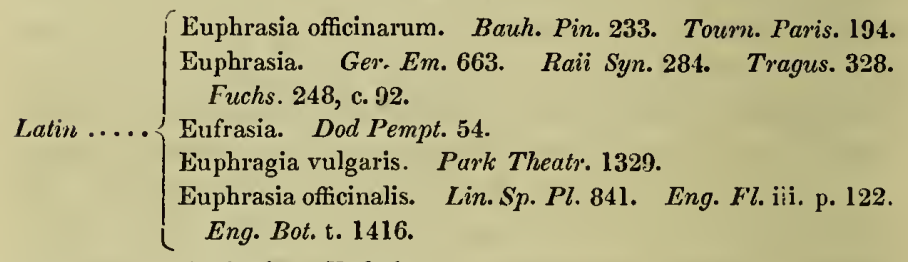

French.... Euphraise; Eufraise.

Italian... Eufrasia ; Eufragia.

Spanish .... Eufrasia.

Portuguese. Euphrasia.

German.... Augentrost.

Dutch .... Oozentroost; Klaaroog.

Danish.... Oientrœest.

Swedish ... Oegentrœst.

Polish .... Swieczki.

Russ. .... Otschanaja pomotsch.

Descriptron.-The root is annual, twisted, dark brown, slender, and furnished with several minute, whitish fibres. The stems are about three or four inches high, branched from the base, and purplish, occasionally simple, nearly square, slightly pubescent. The leaves are small, disposed in pairs, nearly sessile, tending upwards, somewhat concave, smooth, ovate, deeply toothed, 
light grcen, deeper at the margin, and tinged with purple; veins branching, prominent beneath. The flowcrs arc solitary and sub-sessile in the axils of the upper leaves, which they rather exceed in length. The calyx is tubular, angular, pubescent, liglit grcen with purplish ribs, and divided at the margin into four deep, erect, nearly equal, ovate-acuminate teeth. The corolla is bilabiate, white, streaked with purple, yellowish on the palate; the tube cylindrical, curved; the upper lip slightly concave, over-arching the stamens, bifid, with obtuse, emarginate lobes ; the lower lip with three deep, nearly equal, emarginate lobes. The stamens are didynamous, with thread-shaped filaments; anthers two-celled, purple, spurred at the base. The germen is ovate, four-parted, rather hairy, surmounted by a filiform, downy style, terminated by an obtuse, bifid stigma, fringed with minute glands. The capsule is ovate-oblong, compressed, emarginate, two-valved, and two-celled, containing several whitish, striated seeds. Plate 18, fig. 4, (a) the calyx; $(b)$ the corolla seen in front ; $(c)$ the same opened to show the stamens; $(d)$ the fruit enclosed in the persistent calyx.

This lively little plant raises its elegant pencilled flowers on sterile plains and mountainous pastures, throughout the months of July and August, and often to the end of September. It is very generally dispersed over the world, and is met with as far north as Lapland.

The pretty aspect of the flower, gemmed as it is with a yellow eye, most probably suggested the name Eyebright, in Latin Euphrasia, apparently derived from the Greek au $\phi p$ surr, which significs joy or gladness. Some consider that the name was given in allusion to its efficacy in diseases of the eycs, but the first writers who record its medicinal properties are Arnoldus de Villa Nova, who flourished at the beginning of the fourteenth century, and Gordon, who published his Lilium Medicina in 1305.

The older poets, who have noticed this plant, do so in allusion to the remedial powers with which in their day it was so confidently invested. Milton tells us that-

"Michael from Adam's eyes the film removed,

Which the false fruit, that promised clearer sight,

Had bred; then purged with euphrasy and rue

The visual nerve, for he had much to see."

Par. Lost, book xi. 1. 412. 
And Shenstone exclaims-

"Famed euphrasy may not be left unsung,

That gives dim eyes to wander leagues around."

Qualities.-The herb is almost destitute of odour, but somewhat bitter, slightly aromatic, and styptic to the taste. Its astringency is manifested by the dark colour produced in the decoction by sulphate of iron. The juice gives a slight purple tinge to blue paper.

Medicinal Properties and Uses.-No plant has been more celebrated for its anti-ophtlialmic virtues than this. Hildanus * and Lanzonus $\uparrow$ attribute to it the restoration to sight of persons at the age of seventy or eighty years. Arnoldus, Fuchs, Camerarius, Hoffman $\neq$, Lobel $\S$, Francus $\|$, and a host of others, have extolled its virtues in dimness of sight, cataract, inflammation, and other diseases of the eyes. We cannot find any instance recorded by the moderns to corroborate these assertions, and therefore conclude with Bergius I that, although we cannot from our own experience pronounce a decided opinion on its value, we think the testimony of the ancients not to be despised. According to Olatsen, the expressed juice of the plant is used by the Icelanders in all affections of the eyes, and Lightfoot states that the Scotch Highlanders make an infusion of it in milk, and anoint the patient's eyes with it by means of a feather. It has also been commended in jaundice, loss of memory, vertigo, and other similar affections.

Eyebright has been given in powder to the amount of one or two drachms, and the juice in doses of one or two ounces, twice a day. The most celebrated preparation was the vinous infusion of the herb, which was administered in the dose of two or three ounces. The distilled water, though not greatly to be relied on, is certainly a safe collyrium. A strong decoction of the dried plant is the best substitute for the expressed juice.

* Cent. Epist. n. 59.

† Opera Omnia.-Lausanne, 1738, t. i. p. 394.

$\ddagger$ In Schröd. p. 411.

§ Stirp. Advers. p. 210.

II Euphragia herba, medicina polychresta verum oculorum solamen, 1717.

Tा Mat. Med, tom. i. p. 545. 


\section{LXXI.}

\section{FOENICULUM VULGARE.}

\section{Common Fennel.}

Class V. Pentandria.-Order II. Digynia.

Nat. Ord. Umbellifere.

Gen. Char. Calyx obsolete. Petals roundish, entire, involute, with a subquadrate, retuse point. Fruit subterete. Carpels with five prominent, obtuse, keeled ridges, of which the lateral ones are marginal and a little broader. Channels with single vittæ. Seed subsemiterete.-Involucres wanting.

Spec. Char. Stem terete at the base. Leaves biternate; leaflets linear, filiform, pinnatifid; segments awlshaped.

\section{S Y NONYMES.}

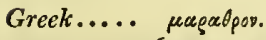

(Fœniculum dulce, \&c. Bauh. Pin. 147.

Foniculum vulgare. Ger. Em. 1032. Park Theatr. 884.

Foniculum. Fuchs, 501. Cam. Epit. 534. Dod. 295.

Latin ..... F Feniculum sive Marathrum vulgatius dulce. Lob. Obs. 448.

Anethum Foniculum. Lin. Sp. Pl. 722. Eng. Bot. t. 1208.

Ligusticum Foniculum. Rolh. Germ. i. p. 124.

Meum Foniculum. Spreng. Prod. p. 32.

Feniculum vulgare. Gartn. fruct. i. p. 105.

French.... Fenouil; Aneth doux.

Italian.... Finnochio.

Spanish.... Hinojo.

Portuguese. Funcho.

German... Fenchel; Gartenfenchel.

Dutch .... Venkel.

Danish.... Fennikel.

Swedish... Fenkal.

Bohemian . Fenkyl.

Polish.... Kopr wlosky.

Arabic.... Razianuj.

Hindoostanie Mayuri.

Sanscrit .. Madhurika.

Tamool.... Perun siragum. 
Description. - The root is perennial, thick, fusiform, whitish, and fibrous. The stems are upright, cylindrical, striated, glaucous, branched, and three or four feet in height. The leaves are large and twice or thrice winged, placed alternately at the joints of the stem on long amplexicaul, membranous, striated petioles; the leaflets filiform, linear, pinnatifid, with awl-shaped segments of a leep green colour. The flowers are disposed in terminal umbels, destitute both of general and partial involucre. The calyx is an obsolete, tumid margin. 'The petals are five, regular, ovate, emarginate, with inflexed points, and of a dark yellow colour. The germen is inferior, ovate-cylindrical, truncated, smooth, striated, and covered with the disk, which is a large, roundish, yellow, glutinous body, dividing into two parts, from each of which rises a short, thick style, terminated by an obtuse truncated stigma. The fruit consists of two ovate slightly compressed carpels, marked with five prominent keeled ridges, of which the lateral ones are marginal and a little broader. Seeds small, ovate, nearly round, on a transverse section. Plate 19, fig. 4, (a) entire flower magnified; (b) fruit of the natural size; $(c)$ the same separating at maturity, magnified.

This plant occurs frequently on chalky cliffs in England near the sea, and near towns at a short distance from the coast, and is very common in gardens. It is a native of Madeira, Spain, the South of France, Italy, and the Caucasus.

Fennel is the $\mu \alpha \rho \alpha \theta=0 \nu$ of the Greeks, and the foeniculum of the Romans, from foenum, hay, the smell of the dried plant resembling that of hay. It is called, provincially, Finkel.

Though formerly considered a species of Anethum or Dill, this plant, witl a few others, now constitutes a distinct genus. The Sweet Fennel (Fœniculum dulce) is by some considered a species of Common Fennel, by others, merely a variety, whose chief differences are produced by climate; since, after being cultivated for several years in a colder climate, it appears to degenerate into the common sort. The seeds are brought from Italy and Sicily, and these are best for medicinal use, but the root and herbaceous part of the Common Fennel are employed.

Qualities AND General. Uses.-The tender stalks are used in salads: the leaves boiled enter into many fish-sauces, and 

are served up with mackarel in many parts of England. The blanched stalks of the Sweet Fennel are eaten with vinegar, oil and pepper as a cold salad, and much esteemed by the Italians, who likewise use them in soups. In Germany, the seeds are used as a condiment in bread and various dishes.

The whole plant has a fragrant, aromatic odour*, which is most developed, however, in the leaves and seeds. It is warm, sweetish, and aromatic to the taste, and becomes more agreeable on being dried. Chemical analysis has procured from the seeds an aromatic and sweet volatile oil, a small quantity of fatty oil which is congealed by cold, an aromatic resinous bitterish extract, and an aqueous extract, which is almost inert. Water extracts its virtues by infusion very imperfectly, bnt distillation in that fluid elevates the whole of its active properties, which are also obtained by digestion in alcohol. According to Matthiolus, when the stems of this plant are cut, in warm climates, there exudes a gum-resin, which is collected by the inhabitants under the name of fennel gum.

Medical Properties and Uses.-. Fennel was well known to the ancients. Hippocrates $\uparrow$ and Dioscorides $\ddagger$ employed it to increase the secretion of milk: the latter says, the herb and seeds if eaten, or boiled in broth, fill the breasts with milk. Pliny reiterates the old opinion, that serpents when they cast their skins resort to this plant to restore their sight $\S$; hence its reputed effects in dimness of sight and blindness $\|$. It has

* "6 _ A savoury odour blown,

Grateful to appetite, more pleased my sense

Than smell of sweetest fennel or the teats

Of ewe or goat dropping with milk at even."

Milton, Par. Lost, book ix. 1. 579.

+ De Morb. Mul. lib. i. sect. v. p. 608. Foes.

$\mp$ Mat. Med. lib. iii. c. 81, p. 205. Sarac.

$\S$ Fœniculum nobilitavere serpentes gustatu senectam exuendo, oculurum aciem succu ejus reficiendo. Hist. lib. xx. c. 23 , p. 538. He also speaks of its medicinal uses, - "Prodest hydropicis, item convulsis, calculos vesic pellit, geniture abundantiam quoque modo haustum facit." $l$. $c$.

If This gave rise to the ancient distich,

"Foniculum, Rosa, Verbena, Chelidonia, Ruta,

Ex his fit aqua, quæ lumina reddit acuta."

Translated by Gerard,-

"Of Fennell, Roses, Veruain, Rue, and Celandine,

Is made a water gond to cleere the sight of eine." 
also been commended in obstructions of the viscera, in smallpox and measles, and for shaking of the hands and other symptoms following the abuse of mercury.

The moderns have found it useful in provoking the secretion of the urine, and the efflux of the menses, in arresting hiccough and vomiting, and removing flatulence; but this success is considered to be owing to its stimulant exciting effects. If these affections, observes $\mathbf{M}$. Broussais, are the consequences of a general state of irritation or local phlogose, or exuberance of the vital forces, it is calculated to do harm*. As a topical application, cataplasms or decoctions of the herb have been found useful in resolving indolent tumours and chronic swellings. The root of this plant was considered one of the five greater aperient roots, and was esteemed by Boerhaave equal to the far-famed Ginseng. Its expressed juice, or a decoction of it in wine, was reckoned diuretic and repellent, and was given in intermittent fevers and eruptive disorders.

The seeds powdered may be given in the dose of half a drachm to a drachm; taken in a glass of wine immediately before or after dinner, they promote digestion, and obviate the unpleasant symptoms frequently complained of after eating. The seeds are also useful correctives of purgative medicines, such as senna. The distilled water is a good carminative for infants, and a vehicle for nauseous remedies; it has also been recommended as a collyrium for weak eyes. The essential oil given in the dose of two to to six drops on a lump of sugar, is serviceable in flatulencies and colic. Externally it has been used in tooth-ache, pain of the ear, and other deep-seated pains. A syrup prepared with the expressed juice, is useful in asthma and old coughs: for this purpose it should be slightly acidulated with lemon-juice or vinegar.

Several galactopoietic powders, principally compounded of fennel-seeds, for augmenting the milk of nurses, are recommended on the continent. Fennel was an ingredient in the Theriaca Andromachi and the Mithridatium.

* Flore Medicale, tom. iii. p. 219. 


\section{LXXII.}

\section{TRIGONELLA FENUM-GRACUM.}

Common Fenugreek.

\section{Class XVII. Diadelphia.-Order IV. Decandria. \\ Nat. Ord. Leguminoss.}

Gen. Char. Calyx campanulate, five-cleft. Carina very small, together with the alæ and vexillum, resembling a tripetalous corolla. Legumen oblong, compressed, or cylindrical, nearly erect, many-seeded.

Spec. Char. Legumen sessile, nearly erect, falcate, longitudinally reticulated, many-seeded. Seeds large, ovate, wrinkled, and dotted.

\section{S Y NON Y MES.}

Greek .... Bovxє९аs, Theophrastus, Hippocrates; $\tau \varepsilon \lambda 15$, Discorides.

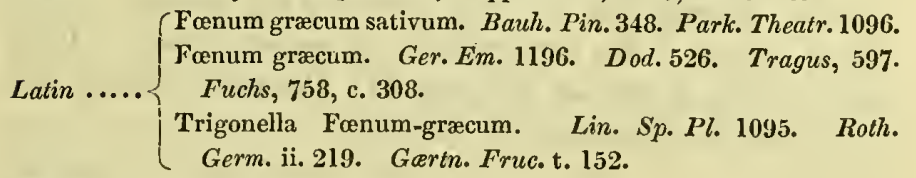

French.... Fenugrec.

Italian. . . F Fiengreco ; Fienogreco.

Spanish ... Fenogreco; Alholva.

Portuguese. Fenogrego.

German ... Bockshorn ; Kuhkornklee ; Fœnugræc.

Dutch .... Hoornklaver ; Fenigrick.

Danish ... Fœnugrack ; Groskhöe; Bukkehorn.

Swedish.... Fenugrek.

Polish .... Fengrek.

Description.-The root is annual, long, tapering, whitish, and fibrous. The stem is erect, round, fistulous, nearly simple, slightly hairy, and rises about two feet in height. The leaves 
are shortly petiolate, disposed in threes, with obovate, obsoletely toothed leaflets, contracted at the base, strong scented; the stipulæ lanceolate, falcate, entire, and pubescent. The flowers are yellowish white, axillary, solitary or twin. The calyx is campanulate, nearly diaphanous, with five subulate ciliated segments. The corolla is papilionaceous, a little longer than the calyx; the carina or keel is very small; the alæ or wings are ovate, entire, reflexed, and elongated at the base; the vexillum or standard is oblong, erect, concave at the base, and indented at the apex. The filamens are ten, nine of which are united, and all furnished with simple anthers. The germen is falcate, surmounted by a short tapering style, terminated by a simple stigma. The fruit is a long, compressed, falcate legume or pod, reticulated with longitudinal veins, tipped with a long beak, and containing several rhomboidal seeds, sculptured on the surface, and of a brownish yellow colour. Plate 20, fig. 1, (a) entire flower; (b) stamens and pistil ; (c) legume; (d) seed.

This plant is a native of the south of France, Greece, Egypt, Barbary, and several other warm climates. It grows in fields and by road-sides, and is occasionally cultivated in this country. It flowers from June to August.

The English name Fenugreek is a corruption of FœnumGræcum, Grecian hay, the name given by the Romans to this plant, because it was very common in ancient Greece. Pliny calls it silicia, as well as fenugræcum; Columella siliqua, and Varro silicula. Theophrastus designates it Bourepas, con's-horn, in allusion to the shape of the seed-vessel, but the common name with the Greeks was $\tau \gamma_{1} \lambda c_{5}$. The present generic name,

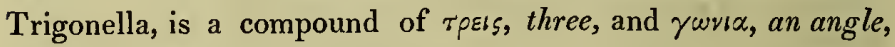
because of the triangular appearance of the flower.

Fenugreek may be cultivated in this country, but it yields an uncertain produce, on account of the inconstancy of our climate. The seeds are brought hither from the South of Europe.

Qualities AND GENERAL Uses.-This plant was frequently employed for culinary purposes by the Egyptians, Greeks, and Romans*. The seeds have been roasted as coffee, and are said to affiord a yellow dye. The meal obtained from the seeds is

- Vide Apicius Colius. De arte coquinariâ, p. 159. 
used by grooms and farriers for horses, both as food and medicine, and for fattening rabbits.

The odour of the seeds is fragrant, resembling that of melilot; when bruised they are disagreeable, and have an unctuous farinaceous taste, accompanied with a slight bitterness. They contain so large a quantity of mucilage, that an ounce boiled in a pint of water, renders that liquid very thick and slimy. Alcohol extracts their odorous matter and peculiar flavour, the analysis of which is unknown.

Medicinal Properties and Uses. - The earliest writers speak of the emollient, lubricating, maturating, and discutient properties of the seeds of this plant; they were likewise employed in the form of decoction in ophthalmia, aphthous ulcers of the mouth, chapped lips, and other external inflammations. "The same preparation has been used in lavements to lubricate the intestinal canal, and to appease irritation consequent to bilious and inflammatory colics, diarrhœa, dysentery, and poisoning by corrosive substances."* They are also esteemed as assisting the formation of pus in inflammatory tumours, and the meal with that intention is made into a poultice with milk. When the object is merely to relieve pain, a strong decoction of the seeds with chamomile flowers, mullein flowers, or St. John's wort, is very serviceable as a fomentation, applied by means of flannel as hot as can well be borne. A similar formula is recommended by Sydenham in erysipelas.

The following will be found a carminative injection of great service, to be used occasionally by persons who suffer from flatulence, costiveness, or colics $\uparrow:-$

Take of Fenugreek seeds of each two drachms;

Linseed ...................

Leaves and flowers of mullein.... , of each a handful;

Caraway seeds,............ one scruple.

Boil the whole (after bruising the seeds) in a pint and a half of water or milk, to a pint, and strain.

* Flore Med. tom. iii. p. 222.

† J. A. Waller, Brit. Dom. Herb. p. 161. 


\title{
LXXIII.
}

\section{ASPIDIUM FIIIX MAS.}

\author{
Male Fern.
}

\section{Class XXIV. Cryptogamia.-Order I. Filices.}

\author{
Nat. Ord. Finices.
}

Gen. Char. Sori roundish, scattered. Involucre orbicular, or orbiculari-reniform and fixed at the sinus.

Spec. Char. Fronds bipinnate; pinnules oblong, obtuse, serrated. Sori near the central nerve. Stipes and rachis chaffy.

\section{S Y NON Y M E S.}

Greek..... xrigs.

Filix non ramosa dentata. Bauh. Pin. 358.

Filix mas. Ger. Em. 1128. Fuchs, 569. Lob. Obs. 473.

Filix mas vulgaris. Raii Syn. 120. Park Theatr. 1036.

Latin .... Polypodium Filix mas. Lin. Sp. Pl. 1551.

Polystichum Filix mas. Roth. Germ. iii. 82.

Aspidium Filix mas. Swartz. Syn. Fil. 55. Smith, Fl. Brit.

iii. 1121. Eng. Bot. t. 1458.

French.... Fougêre male.

Italian.... Felce maschio.

Spanish ... Helecho macho

Portuguese. Feto macho.

German... Farnkraut; Männlichen K'arnkraut; Johanniswurzel.

Dutch..... Maunetjes Varen; Varen manneke; Bosch Varen.

Danish ... Bregne; Needbregne; Molfoorblom.

Bohemian .. Kaprodj.

Swedish... . Træjon; Ormbunke.

Polish..... Paproc.

Description.-The rhizoma is long, thick, creeping, ligneous, of a dark brown colour externally, covered with thick brown 
scales and furnished with many long, black, tough fibres. The lcaves or fronds, which are coiled up in vernation, spring immediately from the rhizoma; they are large, ercet. often three teet in length, growing in a circle, doubly winged, green, smooth, with a short foot-stalk, clothed with redidish brown, nearly transparent, chaffy scales; the pinnules are alternate, lanceolate, acute; the leaflets numerous, rather confluent at the base, lincaroblong, obtuse, and finely serrated. The fructification is scattered over the back of the lcavess, in masses, called sori, which are placed in two rows near the midrib of each leaflet, and are covcred by a membranous involucre (indusium), which is orbicular, somewhat reniform, and fixed by the sinus. Each capsule (theca) is globose, one-celled, attached by a short pedicel and girt with an articulated elastic ring (annulus), which flies back when the capsule is ripe, and discharges the sporules contained in it. Plate 18, fig. 2, (a) the back of a leaflet, shewing the sori; (b) a portion of the leaflct magnified, exhibiting the involucre, with numerous thecæ; (c) a capsule or theca detached, magnified; $(d)$ the same opening to eject the sporules.

This beautiful Fern is very common in Britain, and is frequent throughout Europe, in woods and on shady banks; producing its fructification for the most part from June till August.

The generic name, Aspidium, is formed from $\alpha$ ribs, a shield, which the indusia of some of its species resemble. This species is supposed to be the $\pi \tau$ tafls of Dioscorides, so called from $\pi \tau$ rav , a wing, in allusion to the doubly pinnate leaves.

Several superstitious notions respecting Ferns have prevailed among the common people at different pcriods; such as the following:- Their smell drives away serpents.-If a pregnant woman step over ferns she will miscarly.--The seed scattered in a ring is a defence against enchantments, \&c.

The sporules being cxcessively minute, (a single frond has been computed to produce upwards of a million,) the opinion has been long prevalent that Ferns must be destitute of sceds; hence in Shakspearc, "we have the receipt of fernsced, we walk invisible." *

The other species of Fern best known in this country is the common female Fern or Brakes, (Pteris aquilina,) gencrically

* Henry IV., Act. II. Sren. 1 
distinguished by its continuous, linear, marginal sori, and involucres which open outwardly, and are formed of the inflexed margin of the frond. It abounds on all our heatlss and commons, and is well known as forming an excellent cover for game, and as useful for many economical purposes.

Qualities and General Uses.-The young shoots of the male Fern have been eaten in the same manner as asparagus. The fronds, in common with those of the female Fern, afford a useful thatch for outbuildings, and an excellent litter for horses and cows, and a fuel for heating ovens. Gunner* informs us that in Norway they are dried and steeped in hot water, and in this state are used as a substitute for hay in times of scarcity; the herbage also is employed to stuff beds and mattresses. The ashes of the plant, when burnt, contain a large proportion of vegetable alkali, which is much used in the manufacture of glass. The poorer class of people mix these ashes with water, and form them into round masses, which they call fern balls, which being heated in a fire are used as a ley for scouring linen. Delechamp states that the people of Normandy, in times of extremity, have made a kind of bread of the root; although this part is so astringent as to have been employed in dressing leather. The inhabitants of Siberia use it in brewing, and it is probably one of the best substitutes for hops, "as it contains both gallic acid and tannin, which are absent from most of the other bitter plants which have been proposed as surrogates, and failed, from being unable to precipitate the glutinous mucilage which renders unlıopped beer so liable to turn sour." $\downarrow$ The foregoing account will apply equally well to the Brake or female Fern.

The rhizoma $\ddagger$ is of a dark brown colour externally, and yellowish white within. Its odour, though feeble, is nauseous, and the taste is at first styptic, but soon becomes sweetish, slightly aromatic, and bitter. The aqueous extract has the smell and taste of the substance itself, but the alcoholic extract is more bitter. According to Morin it contains a trace of volatile oil, fatty oil, sugar, starch, tannin, pectine, malic and

* Flora Norveg. P. i. p. 5.

+ Burnett's Outlines of Botany, p. 328.

† In popular language the root. 
gallic acids, combined with lime and potass, phosphate of line and lignin; the ashes yield silica, alumina, and oxide of iron.

Medicinal Properties andUses. - The efficacy of the rhizoma of male Fern as a specific against worms has been credited from the remotest times of which we have any medical record. Theophrastus*, Galen $\uparrow$, Pliny + , and Dioscorides $\S$, all extol its virtues as an anthelmintic. It has also been recommended in gout, rickets, scorbutic affections, hypochondriasis, inveterate ulcers, and obstructed menses, and it is asserted by Aetius, to provoke abortion, which Olivier \| endeavours to confirm. Pauli $\mathbb{1}$, Hoffmann, Andry, Marchant, and many others, have administered it with great success against tapeworms as well as other intestinal parasites. Murray** cites numerous cases. Madame Nouffer, a surgeon's widow, acquired great celebrity, about half a century ago, by the sale of a secret remedy in the cure of the tape-wo $\mathrm{m}+\mathrm{t}$. This, after a trial of its efficacy by the principal physicians of Paris, was bought by the French government for 15,000 francs, and published by their order. "In this, as in almost every other instance," says Chaumeton, "the Fern root has been accompanied with some powerful cathartic, so that it is difficult to determine which is most efficacious, or whether the success obtained is not attributable to the latter only." ++ Wendt \$§, however, Gmelin ||||, and others, affirm that given alone, in the dose of two or three

* Hist. Plant. lib. ix. cap. 22.

+ De simp. med. lib. viii. ed. Ricci.

$\$$ Hist. lib. xxviii. cap. 9 .

$\$$ Mat. Med. lib. iv. cap. 186.

|| Journ. de Med. de Vandermonde, tom. xii. p. 129.

T Quadrip. Bot. p. 333, ed. Fick.

* Apparatus Med. vol. v. p. 456-471.

十† The following is the recipe :-After a supper of panada, and the injection of an emollient clyster, the patient is to take three drachms, or an infant one drachm, of the powdered root of male Fern, in common water ; and in two hours a strong dose of calomel and scammony. If this does not operate speedily, it is to be followed by a dose of purging salts, and if the worm be not expelled in a few hours, the medicine is to be repeated at proper intervals.

+† Flore MIed. tom:

$\S \S$ Nachricht vom clin. Institut zu Erlaugen.-Pens, r, et vi. p. 45.

III Dissert. consid. gen. filicum. p. 50. 
drachms, it has expelled fragments of tape-worm from different individuals. Peschier, of Geneva, appears to have set the question at rest by his successful employment of the fatty principle of the buds, which he obtains by digestion in sulphuric ether. This preparation has an oily consistence, and is mixed with some extractive substance to form pills, each containing a drop of the fatty matter. Eight of these pills are often sufficient, but in some cases it is necessary to augment the dose to thirty drops divided into small doses: the exhibition of this quantity, however, should occupy several days. M. Peschier asserts that the medicine thus exhibited does not fatigue the patient, while it destroys the worms, which may afterwards be expelled by any mild purgative*. If this be correct, the gratuitous assertion so often made, that this long-known remedy owes its efficacy as a vermifuge to its feeble astringent and tonic properties, and that cinchona bark would answer just as well, falls to the ground.

The thizoma of male Fern is given in substance, powdered, to the amount of one to three drachms, in wine, or milk, or mixed with loney; and in decoction to the extent of half an ounce. Forestus highly extols a decoction of it with dorlder, in affections of the spleen, by which he seems to intend a disease of the digestive organs, often occasioned by tenix, and the slimy matter which forms their nidus in the intestines. The expressed mucilaginous juice of the plant has been much lauded as an application to burns.

* Magendie's Formulary, translated by Gregory, p. 191. 

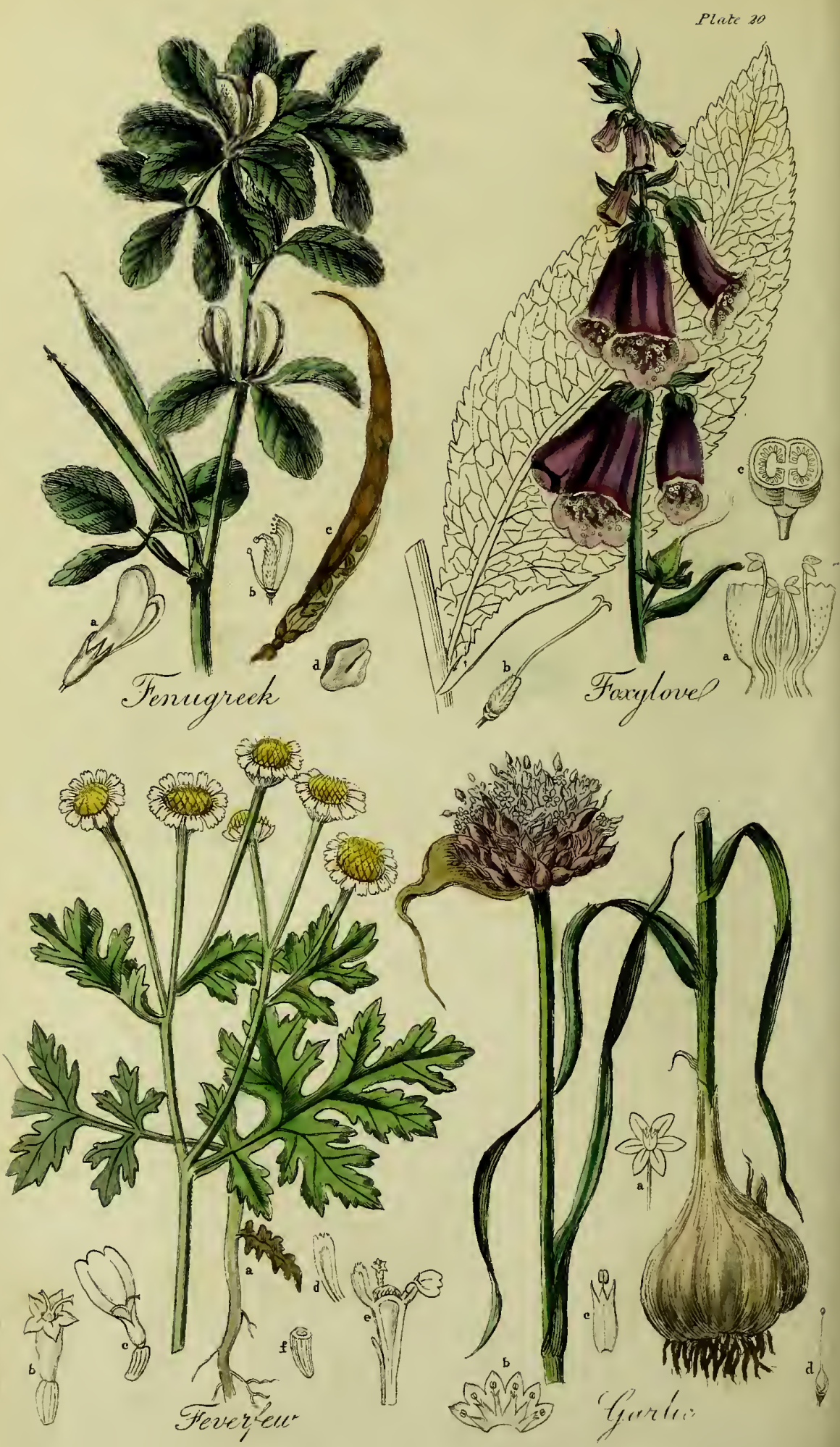


\section{IXXXIV.}

\section{PYRE'THRUM PAR'THENIUM.}

Common Fecerfew.

Class XIX. Srngenesia.-Order II. Polygamia

SUPERFLCA.

Nat. Ord. Composits.

Gen. Char. Involucre hemispherical, imbricated with scales, whose borders are membranous. Receptacle naked. Fruit crowned with a membranous border.

Srec. Char. Leaves petiolate, flat, bipinnate; segments ovate, cut. Peduncles branched, corymbose. Stem erect. Involucre hemispherical, pubescent.

S Y NONYMES.

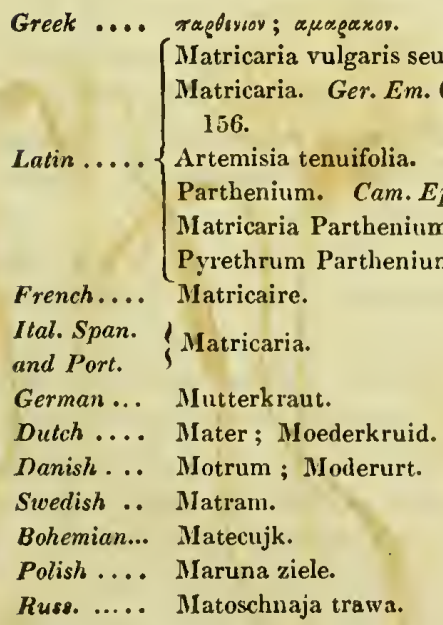

Description.-The root is peremial, rather thick, much branched, with numerous long tufted fibres. The stem is erect, 
firm, smooth, striated, branched, and usually about two feet in height. The leaves are alternate, petiolate, of a light ashcoloured green, pinnated; the pinnules more or less ovate, decurrent, pinnatifid, with incised, somewhat obtuse lobes. The flowers are large, pedunculate, and disposed in a corymbose manner at the extremity of the stem and branches. The involucre is hemispherical, imbricated with scales which are membranous, and somewhat villous at the margin. The florets of the disk are numerous, perfect, tubular, and five-toothed, yellow; those of the ray pistilliferous, short, oblong, nearly round, with three small terminal teeth, white. The filaments five, very short; anthers forming a hollow cylinder. The germen angular, abrupt, with a short filiform style, and a bifid, obtuse, spreading stigma. The receptacle is naked, slightly conical, brownish black, dotted. The fruit is oblong, truncate at the base, smooth, furrowed, whitish, destitute of pappus, crowned with a shallow, slightly toothed, membranous border. Plate 20, fig. 3, (a) the root; (b) floret of the disk magnified; (c) floret of the ray; $(d)$ scale; (e) vertical section of the flowering axis ; $(f)$ seed magnified.

This plant is found wild in stony and uncultivated places, and about hedges. Deserted gardens into which it has once been admitted are soon overrun with it. It flowers in July.

Feverfew is supposed to be the rxplzyır of Dioscorides, so called from its use in disorders of the uterus, and of which Matricaria, is a kind of Latin version. Pyrethrum is derived from $\pi v p$, fire, in allusion to its acrid roots.

A variety with double flowers is cultivated in gardens for its ornamental character. In this state, the florets of the disk are so metamorphosed as to resemble those of the ray. The other British species are the Corn Feverfew, (Pyrethrum inodorum, common in fields, with sessile, bipinnatifid leaves, having capillary segments; flowers with a large ray, and a very convex disk, and its fruit with an entire border. The Sea Feverfew (Pyrethrum maritimum) very much resembles the last, except that the flowers are smaller and the border of the fruit is lobed.

Qualimes.-The odour of Feverfew is peculiar, strong, and pungent, resembling chamomile and tansy, but more developed, and is partly lost in drying. It is bitter, hot, and nauseous to the taste. It contains a small quantity of resin combined 
with a bitter mucilage, and a blueish volatile oil, which separates on distilling the plant in water. Its other principles are also obtained by infusion in water and alcohol. The aqueous extract is very bitter, saline, and but very slightly aromatic.

Medicinal Properties and Uses. - It has been remarked that the energy of the sensible qualities of plants is indicative of potent medicinal virtues, and Feverfew confirms this assertion. This plant exercises a powerful tonic action upon the animal economy, hence result the antispasmodic, stomachic, diuretic, emmenagogue, resolutive, and other properties attributed to it. It has been more especially celebrated for its specific action on the uterus, promoting the menstrual evacuation and the lochial discharge, aiding the expulsion of the placenta, facilitating difficult labours, and curing hysteria. In this character it has been regarded, more or less, since the age of Dioscorides *, and is highly recommended by Simon Pauli $\nmid$ and many other physicians, though neglected by practitioners in the present day : few plants however are more extensively employed by country people. It is also asserted by Ray + and Lange $\$$ to be very useful in expelling worms, and Miller ॥ states that two ounces of the expressed juice have been given with advantage in intermittent fevers, an hour before the paroxysm;-hence the name Feverfew. Gerard 9 mentions its use in agues. Externally the decoction of Feverfew is employed in fomentations, generally combined with chamomile flowers, and sometimes with wormwood and St. John's wort. These fomentations are particularly applicable to cases of severe after-pains and windy colics, head-aches, \&r.

It may be given in powder in the dose of one or two scruples. An infusion of two drachms in a sufficient quantity of water or wine, is a good substitute for the expressed juice, and in the diseases above mentioned may be used in the form of tea, as common drink.

- Mat. Med. lib. iii. c. 155, p. 236.

+ Quadrip. Bot. p. 432.

‡ Hist. Plant. tom. i. p. 357.

$\S$ Brunsv. Dom. p. 72.

|| Bot. Off. p. 288.

I He writes, "It is used both in drinks, and bound to the wrists with bay salt, and the powder of glasse (!) stamped together, as a most singular experiment against the ague."-Herbal, p. 653. 


\section{LXXV.}

\section{SCROPHULARIA AQUATICA.}

\section{Water Figwort, or Water Betony.}

Class XIV. Didynamia.-Order II. Angiospermia.

Nat. Ord. Scrophularinez.

Gen. Char. Caly $x$ five-lobed, or deeply five-cleft. Corolla subglobose, bilabiate; limb contracted; upper lip with two lobes and frequently a small scale about the middle, the lower three-lobed. Capsule two-celled, two-valved, the margins of the ralves turned inwards.

Spec. Char. Leaves elliptical, orate, nearly cordate, toothed, crenate. Stem winged at the angles.

S Y N ONY MES.

Latin.... $\left\{\begin{array}{l}\text { Scrophularia aquatica major. Bauh. Pin. 235. Raii Syn. } 283 . \\ \text { Betonica aquatica. Ger. Em. 715. Park Theatr. } 613 . \\ \text { Scrophularia fœmina. Cain. Epit. 867. } \\ \text { Scrophularia aquatica. Lin. Sp. Pl. 864. Eng. Fl.v. ii.. p. } \\ \text { 137. Eng. Bot. t. 1544. }\end{array}\right.$

French... Scrofulaire; Scrofulaire aquatique; Betoine d'eau.

Italian.... Scrofularia acquatica.

Spanish ... Escrofularia aquatica.

Portuguese. Escrofularia dos rios.

German.... Wasser-Braunwurz; Wasser Kropfwurz.

Dutch..... Water Speenkruid.

Belgic..... St. Anthonis kruid; Beekschuim; Water Betonie.

Russ....... Naryschnik.

Description.-The root is composed of slender tufted fibres, somewhat fasciculate, without tubercles. The stem is erect, smooth, branched, quadrangular, winged at the angles, and rises to the height of three or four feet. The leaves are opposite, petiolate, ovate-oblong, cordate at the base, rather obtuse, crenate and somewhat toothed, nerved, smooth, and of a deep green colour, paler beneath. The flowers form naked terminal panicles, remotcly branched, furnished with small lanceolate 
bracteæ. The calyx is divided at the margin into five rounded lobes, edged with purple. The corolla is reddish purple, much longer than the calyx, tubular, nearly globose, with an inflated tube; limb short, two-lipped; the upper lip orbicular, with two lobes, and a small scale or abortive stamen within it; the lower lip with three lobes, of which the middle one is reflexed. The stamens are four, didynamous, inclined towards the lower lip, with two-celled anthers. The germen is superior, ovate, terminated by a simple style and stigma. The capsule is ovate-acuminate, two-celled, two-valved, the margins of the valves turned inwards, containing several small seeds. Plate 18, fig. 3, (a) calyx and pistil; $(b)$ corolla; $(c)$ the same opened to show the stamens; $(d)$ the pistil; $(e)$ capsule; $(f)$ the same cut transversely.

- This plant flourishes by the sides of rivers, and in watery places. Its flowers, which are not inelegant, appear in July and August.

Figwort seems to have becn unknown to the ancients, it is at least unnoticed in their writings. The generic name was bestowed in consequence of the reputed efficacy of the plant in scrofula. The species here described is called in some counties Brown-wort, and in Yorkshire Bishop's leaves.

The species best known, perhaps, is the Knotted Figwort, (Scrophularia nodosa,) with a large, thick knotty root, heartshaped triangular acute leaves, doubly serrated at the margin, and greenish purple flowers. It is frequent in woods and moist ground, and is very similar in properties to the one here figured. There are two other indigenous species, Balm-leaved Figwort, (S. Scorodonia, and Yellow Figwort (S. vernalis).

Qualities. - Water Figwort exhales when fresh a strong disagreeable odour, which is supposed to be of the narcotic kind and is partly lost in drying. The taste is bitter, rather acrid and nauseous. It yields its active matter both to water and alcohol. "The aqueous infusion is but slightly bitter, has the odour and taste of cherry-kernels and is not very unpleasant : a solution of sulphate of iron renders it of a dark semi-opaque green, but it does not affect litmus paper."*

Goats eat this plant, but other animals refuse it. Wasps and bees resort greatly to the flowers. 
- Medicinal Properties and Uses,-Little is known of the medical properties of this plant*, its ancient character as a vulnerary being no recommendation in our day. Its celebrity in this respect appears to have been heightened by its employment at the siege of Rochelle in 1628, when, in defect of other remedies, the soldiers applied it to their wounds, which it speedily liealed $\downarrow$. Lochnerus $\ddagger$ mentions an instance of a dreadful wound which was cured by the outward application of the juice, the patient at the same time drinking a strong decoction of the herb. The leaves have been much used to correct the disagreeable taste and smell of senna, without altering its purgative properties. Boerhaave $\S$ states that half a drachm of the dried leaves mixed with two drachms of senna, has an excellent effect. The decoction and distilled water are recommended as cosmetics.

The employment of the tubercled roots of Knotted Figwort in piles and scrofulous tumours $\|$, is thought to have originated in the visionary doctrine of signatures. Many celebrated physicians, however, such as Arnoldus, Henricus ab Heers, Mayerne, Ettmuller, and others, implicitly believed in its efficacy. Ettmuller prescribes from half a drachm to a drachm of the root, sliced and infused in wine, to be taken three or four times in the day; this he affirms will afford relief to the patient, whether the piles be bleeding or not, or in any stage of them whatsoever. The powdered root was employed for the same purpose in the dose of one or two scruples, and to expel intestinal worms. A decoction of an ounce of the root in a pint and a half of water, taken in the dose of a cupful two or three times a-day, has been recommended with the same intent; also as a lotion for cutaneous eruptions. Cataplasms and fomentations with the root, and ointments made of the leaves were not less esteemed applications to hæmorrhoids, ulcers and scrofulous tumours.

* Linnæus calls it "sudorific and anodyne."

$\dagger$ Chomel Pl. Usuelles, tom. iii. p. 63.

$\ddagger$ Eph. Nat. Cur. cent. vii. p. 145.

\$ Hist. Pl. Hort. L. B. i. p. 316.

II In this disease it was often used as an amulet, to be hung round the neck. We may smile at this practice and call it a superstition of the dark ages, but it was not more absurd than the belief in the prophylactic virtues of a rbild's caul. 


\section{LXXVI.}

\section{ABIES COMMUNIS.}

Norway Spruce Fir.

Class XYI. Monaecia.-Order VIII. Monadelphia, Nat. Ord. Conifere.

Gen. Char. Males; Anthers two-celled. Females; Scales imbricated in a round cone, bracteate at the base, digynous. Pericarps attached to the inside of the scale, winged, deciduous. Stigma bi- or trifid. Cotyledons three to nine.

SpEc. Char. Leaves solitary, four-cornered. Cones cylindrical; scales rhomboid, flattened, repand at each end, eroded.

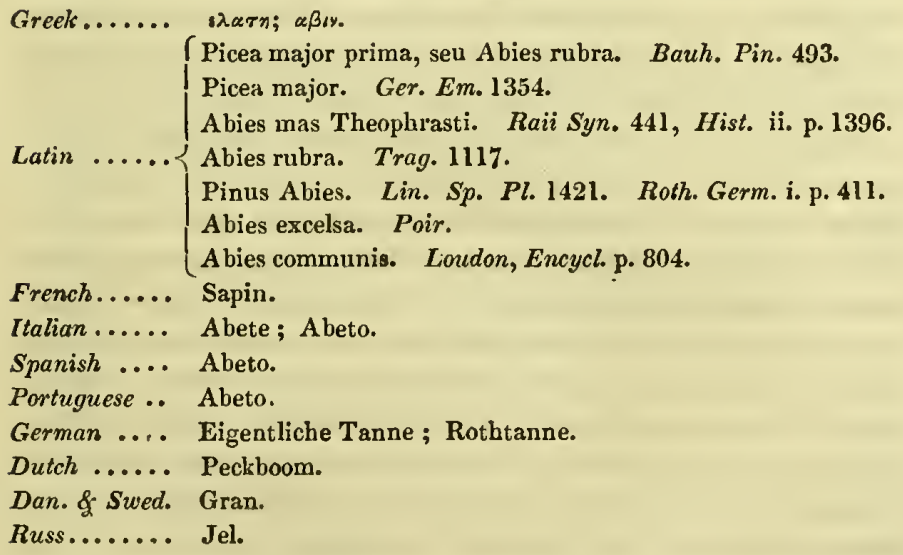

Description.-The tree is usually straight, pyramidal, often attaining the height of 100 feet or more; covered with a reddish, scaly bark. The leaves are thickly set upon the branches, 
ascending, somewhat imbricated, solitary, linear-subulate, mucronate, smooth, scarcely an incl long, with four rather unequal angles, of a shining dull green colour, and destitute of stipulæ. The flowers are monœcious, terminal: males in catkins, which are erect, ovate, cylindrical, purplish, on short foot-stalks, and furnished with numerous spreading bracteæ; the anthers yellow with a roundish, reniform, deeply toothed crest of a crimson colour. The female catkins are sessile, oblong, erect, and of a rich crimson hue, with the germen spread open and resembling a fiat scale, destitute of style or stigma, and arising from the axil of a membranous bractea. The fruit consists of a cone formed of the scale-shaped germens or ovaries, pendulous, and solitary from the end of the branches, long, nearly cylindrical, and of a purplish colour; the scales flattish, imbricated, smooth, rhomboid, wavy at the margin and notched at the point. The seeds are small, ovate, compressed, covered with a hard crustaceous integument, and furnished with two thin elliptical wings. Plate 21, fig. 1, (a) anthers; (b) female catkin; (c) scale of the same detached; $(d)$ seeds ; $(\epsilon)$ the ripe cone; $(f)$ leaf.

This magnificent tree is a native of Norway, Russia, Germany, and some parts of Northern Asia, and has been cultivated in this country from about the year 1548. It flowers in April.

According to Bullet, the term Abies is derived from abetoa, the name for the Fir in one of the Celtic dialects. It was also called by the Greeks $\alpha B_{b} \sigma s$ and $\alpha B_{b} v$ as well as $\varepsilon \lambda x \tau \eta$.

The Pines, Firs, and Larches were formerly included in one genus, Pinus, but modern botanists are convinced of the necessity of separating them, and the species here under notice is taken as the type of a new genus; Abies. This contains about twelve species, distinguished by their pyramidal growth and solitary leaves. The most important are;-the black and red spruces ( $A$. nigra et rubra), American firs, the latter yielding durable wood, much used in ship-building; and from the branches of the former, spruce beer is obtained; - the Silver Fir ( $A$. picea) a most majestic tree, abounding in resinous matter; the Balm of Gilead Fir, ( $A$. balsamea,) an elegant tree which by incision yields the Canada balsam; the Hemlock Spruce, ( $A$. Canadensis, ) the bark of which is a good substitute for oak-bark in tanning; and the Abies Douglassi, which sometimes attains the height of 200 feet, and affords valuable timber and resin. 
Qualities and gexeral. Uses.-The Norway spruce is well known as affording the useful timber deal, which is imported in such vast quantities from Christiana and Bergen, and is extensively used in building; also for masts, spars, scaffoldingpoles, implement handles, \&c. "It is peculiary valuable in plantations as a nurse, from being evergreen and closely covered with branches, by which radiated heat is retained ; from its conical shape and rigid stem, by which it does not suffocate or whip the adjoining trees; and from its being an excellent shelter for game. It will not however grow in elevated situations, where the common pine and larch will flourish." "**

Linnæus + informs us that the Laplanders select the long and slender roots of this Fir, and after boiling them in water for about an hour, with a great quantity of ashes, scrape them while yet warm with a knife, and then twist them into ropes. "They make elegant baskets of the same material, and boats of very slender planks of the wood, sewed together with the roots lest iron should make them too heavy. They also collect the resin, fresh and almost liquid, from the tree, and masticate it until the bitterness is nearly extracted, after which it is carefully preserved and called Tuggkoda. This they are, constantly in the habit of eating when assembled in their religious edifices, and though it occasions a great waste of saliva, it may perhaps act as an antiscorbutic. These people are very fond of ardent spirit, and althuugh not able to prepare it themselves, they drink with avidity that which is brought them by strangers; the consequence is, that after the delirium lias subsided, they are seized with intolerable headaches. As a remedy for this they take the young shoots of the Spruce Fir and apply them bruised to the part affected; some to expedite the cure hold their hearls down to the fire, and continue in this position till they are almost lifeless.-In Finmark, the tops of the young shoots are gathered and chopped up with oats, as winter food for horses."

Spruce beer is made from several species of Fir, and frequently from the one now before us, by boiling the young shoots in water, with the addition of molasses or coarse sugar, which is then put into a cask, and after a slight fermentation is securely corked to prevent the escape of the carbonic acid gas.

The substances procured from this tree, which are used in medicine, are resin and Burgundy pitch. The former, called Thus in the old Pharmacopæias, exudes spontaneously from the bark and concretes as it exudes. It is brought to us in its natural state in the form of tears or small masses, and is often an ingredient in the frankincense of the shops. Burgundy pitch is ob-

- Loudon's Encyclopxedia of Plants, p. 804.

† Flora Lapponica, ed. Smith, p. 287. 
tained by making incisions quite through the bark to the wood. The operation is performed from April to September, and the juice concretes in the form of flakes, which are detached by an iron instrument. The flakes are then put into large boilers with a sufficient quantity of water, melted, and then strained by a press through coarse cloths. It has a terebinthinate odour and taste, is brittle, opaque, and of a light yellow or reddish brown colour. It is rendered soft and unctuous by a moderate heat, and is very tenacious. Alcohol entirely dissolves it.

Turpentine, tar, and resin will be described under the article Pine.

Medicinal Properties and Uses. - Burgundy pitch is never employed internally, but it forms an excellent adhesive and moderately warm stimulating plaster, exciting some degree of irritation, and occasionally a slight eruption and serous exudation from the parts to which it is applied. It is an useful application to the chest in coughs, pains of the muscular parts of the chest, and dyspnœa, also to the loins in rheumatism and lumbago. It should be renewed every three or four days, and so continued for any length of time. It enters into one or two compound plasters of a stimulant nature. Spruce beer*, or a decoction of the young branches of this tree, has been highly extolled as an antiscorbutic. It is thought to promote urine and perspiration, and for its sudorific property has been prescribed in rheumatic and gouty pains, especially in the complaint called flying gout, and in scurvy $\downarrow$. Ettmuller directs a spirit to be distilled from it immediately after fermentation, which has a very agreeable taste and smell, and may be substituted for the decoction. "When the young tops or cones of the fir cannot be procured, the extract or essence of spruce may be used in the same manner. It is carried out in this form by the ships of the royal navy, and is an excellent preventive of scurvy." + The effluvia of the Norway Spruce are supposed to render the air salubrious, on which account it is usual in Sweden to cut the branches into pieces of about half a finger length and strew them on the floors of apartments tenanted by invalids $\S$.

* It is to be observed that the article often sold in the shops by the name of " spruce beer" is quite inert and worthless.

+ Hermann Cynosura, tom. ii. p. 193.

† Waller, Brit. Dom. Herb. p. 150.

$\S$ Murray, App. Med., tom. 1, p. 40. 


\section{LXXVII.}

\section{ACORUS CALAMUS.}

Common Sweet Flag.

\section{Class VI. Hexandria.--Order I. Monogynia.}

Nat. Ord. Aroider.

Gen. Char. Flowers arranged upon a spadix without a spatha. Perianth of six scales, inferior. Stigma sessile. Capsule indehiscent, three-celled, many-seeded.

Spec. Char. Point of the scape very long, leafy.

\section{SYNONYMES.}

Greek....... «x«९os.

(Acorus verus, sive Calamus aromaticus officinarum. Bauh. Pin. 34. Raii Syn. 437. Park Theatr. 140.

Latin ..... A corus verus officinis falso Calamus. Ger. Em.62. Typha aromatica clava rugosa. Hist. ox. s. 8. t. 13. Acorus Calamus. Lin. Sp. Pl. 462.

French .... Roseau aromatique; Acore odorant.

Ilalian ...... Acoro; Calamo aromatico; Canna odorifera.

Spanish...... Acoro aromatico.

Portuguese... Acoro Calamo; Canna cheirosa.

German...... Kalmus; Gewürz kalmus; Ackerwurzel; Deutsche Zittwer.

Dutch...... Calmus.

Danish....... Calmus.

Swedish...... Kalmus.

Bohemian.... Prustworec.

Polish...... Tatarskie ziele.

Persian...... Vadge.

Malabar.... Vaymbu.

Japanese... Kawansob.

Arabic...... Vage.

Sanscrit..... Vacha; Haimavati.

Tamool....... Vassambu. 
Description.-The rhizoma is horizontal, long, about the thickness of the finger, sub-compressed, jointed, marked with the remains of former leaves, and furnished with several fibres or rootlets; it is externally of a brownish green or reddish white colour, internally white, soft and spongy. The leaves are from two to three feet in length, erect, ensiform, acute, sheathing often undulated at the edge, and of a yellowish green colour. The flowers are arranged on a spadix issuing laterally from a triangular, slightly compressed scape, which proceeding upwards tapers into a leafy expansion, rather narrower and shorter than the leaves. The spadix itself is cylindrical, sessile, about three inches in length, attenuate at each end, and covered with small pale green flowers, placed quincuncially. The perianth consists of six scariose leaves or scales, equal, concave, quadrateoblong, obtuse, keeled. The stamens are six, opposite the scales, which they rather exceed in length; filaments thick, terminated by two-celled anthers turned inwards. The germen is superior, oblong, hexagonal, without a style, and terminated by a small simple stigma. The capsule is a kind of berry, pyramidal, triangular, obtuse, furrowed, three-celled, and containing several oval seeds. Plate 19, fig. 2, (a) entire flower ; (b) stamen ; (c) antleer deliscing, magnified; $(d)$ germen ; $(e)$ seed magnified.

This singular plant occurs on the banks of rivers and in watery places, in the middle and south-eastern counties of England; very rarely in Scotland. It is a native of Asia, and is supposed to have been introduced into Europe from Bithynia. It flowers in June.

The generic name is derived from rop from its use in diseases of that organ*. Calamus was a general name with the Romans for anything resembling a cane or reed; as the English word flag is, for drooping or prostrate objects, and the foliage of this plant resembling that of the Iris, it has received a similar appellation.

Qualities and general Uses.-In some counties of England in which this plant abounds, it was formerly used to strew the floors of houses instead of rushes, and for the sake of its

* "Succus ejus ea quæ pupillis officiunt, caliginemque offundunt, discutit." Dioscorides, Mat. Med. lib. xxv. c. 13. 
agreeable odour it is used for the same purpose in cathedrals on festival days. The root is used for several articles of perfumery, and the French snuff a la violette, is scented with it; brewers are reputed to employ it to give a flavour to their porter; and throughout the United States it is used by the country people as an ingredient in wine-bitters, and by the Swedes in spirits distilled from corn. The whole plant is rejected by cattle, and is obnoxious to most insects, hence it has been proposed to be placed in drawers and on shelves to protect clothes, books, \&c., from devastation. The volatile aromatic oil obtained from it, like that procured from the rind of the Birch tree, would no doubt prevent monldiness. It has been used for tanning leather. The root is the only part used in medicine, but the leaves are also aromatic, Two varieties are met with in commerce. The one brought from Tartary and Poland, generally known by the name of Acorus verus, is of the length and thickness of the finger, knotted, cylindrical, slightly flattened, reddish externally, whitish within; the other called Calamus aromaticus, which comes from the Levant by way of Marseilles, is about the thickness of a quill, reddish grey without and white internally*. Both have a pleasant odour and a warm, pungent, bitter, and aromatic taste, which is improved by drying. The aromatic principle is an essential oil, which can be separated by distillation; it is lighter than water, of a pale yellow colour, and instantly decomposes sulphuric acid. The other constituents of the root are, according to Tromsdorff, resin, extractive, witl a little muriate of potass, gum, phosphate of potass, starch, and woody fibre.

Medical Properties and Uses. - The medical virtues of this plant were known to the ancient Greek and Arabian physicians. It is one of the few aromatics indigenous to Europe, and by no means deserves the neglect with which it is treated by the moderns. In consequence of its prompt and powerful tonic action upon the system, it has been regarded as excitant, stomachic, diaphoretic, diuretic, incisive, \&c. It is therefore useful in colic, flatulence arising from dyspepsia, and in vertigo, headaches, \&c., proceeding from the same cause. Some authors have praised its effects in leucorrhæa, pulmonary chronic catarrhs, and dysentery; but where there is a tendency to

* Flore Med. tom. vi. p. 58. 
hæmorrhage it should be given with caution. The best effects have been obtained from it in the low sinking stage of malignant fevers, and it is an excellent adjunct to bark and sulphate of quinine, in the cure of intermittents. Agues have been cured by a free use of the tincture, and it proves very beneficial in that distressing complaint to which sailors are liable, well known by the name of wind colic ; given in hot decoction in the manner of ginger tea, it quickly relieves the distressing swelling of the abdomen *.

It may be advantageously given in substance, in the dose of a scruple to a drachm. It is usefully combined with magnesia and chalk in the flatulent colic of infants $\uparrow$. An infusion of two to three drachms of the root in a pint of water or white wine is an excellent stomachic: a wine-glassful to be taken at a time. The volatile oil may be given in combination with sulphate of quinine in the dose of two to six drops. The fresh root candied, is used in Turkey and India by dyspeptic patients, and is masticated as a preservative against epidemic diseases.

* Barton, Veg. Mat. Med. vol. ii. p. 66.

$\uparrow$ Thomson, Elements of Mat. Med., p. 147. 


\section{LXXVIII.}

\section{IR IS PSEUD-A CORUS.}

\section{Yellow Flag, or Water Iris.}

\section{Class III. Triandria.-Order I. Monogynia.}

\section{Nat. Ord. IRIDEE.}

Gen. Char. Perianth single, petaloid, six-cleft, each alternate segment longer and reflexed. Stigmas three, petaloid, covering the stamens.

Spec. Char. Leaves flat, ensiform. Perianth beardless, its inner segments smaller than the stigma.

\section{S Y NON Y MES.}

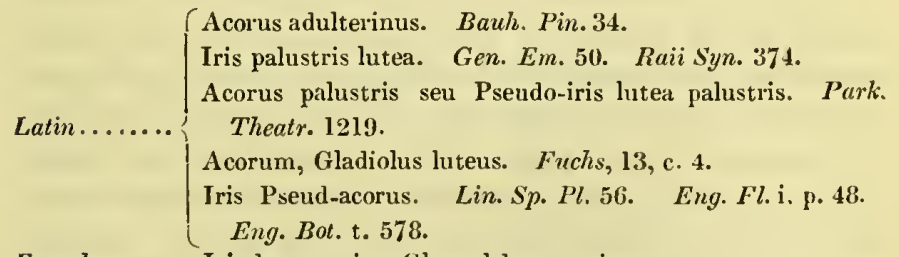

French..... Iris des marais ; Glayeul des marais.

Italian...... Iride Gialla ; Acoro bastardo.

Spanish....... Acoro bastardo ; Lirio espadanal.

Portuguese... Lirio amarelho dos charcos.

German...... Wasserschwurtel; Gelbe Schwertlilie.

Dutch....... Geel Lisch; Valsch Lis.

Danish ..... Swœrdlilie.

Swedish .... Svardslilja.

Polish ...... Mieczyk z'ólty.

Russ. ..... Kasatnik.

IIungarian... Sarga vizi Lilioin.

Description.-The rhizoma is fleshy, tuberous, horizontal, blackish externally, yellowish red and spongy within, and 
furnished with many thick, cylindrical, descending fibres. The stem is erect, nearly cylindrical, rather zig-zag at the summit, smooth, three to four feet in height. The leaves which spring from the root are long, upright, plane, broadly ensiform, striated, acute, smootll, equitant at the base ; cauline ones shorter, alternate, sheathing, of a deep green colour. The flowers are large, showy, deep yellow, situated towards the summit of the stem, on short alternate peduncles, with two or three membranous bracteæ at the base. The perianth (calyx) consists of six segments or pieces, resembling petals, of which the three inner ones are smalier and erect, the three outermost are large, roundish-ovate, reflexed, and marked near the base with purplish lines, not bearded. The three stamens are furnished with flat, tapering stigmas and oblong, brownish purple anthers, bent down by the stigmas. The germen is inferior, oblong, three-sided, with a very short style, and three large, yellow, obtuse stigmas, resembling petals, bipartite, and irregularly serrate. The capsule is triangular, three-celled, three-valved, containing numerous large rounded seeds. Plate 19, fig. $3,(a)$ pistil and stamens; (b) ripe capsules, one of which is opened; (c) seed.

This plant is very frequent in marsliy places, wet meadows, woods, and by the sides of lakes, growing in extensive patches in the Hebrides and the North of Scotland. It is indigenous to Europe from Italy and Lapland. It flowers in June and July.

The generic name was given by the ancients to this assemblage of plants, on acconnt of their beautiful and varied colours; according to Plutarch, from a word in the ancient Egyptian tongue, which signified eye; the eye of heaven. The species here described has the English vernacular names of Yellow Flag, Water Flag, Bastard Fleur-de-Luce, and in the North, Seggs.

About one hundred species of Iris have been described. Many of them are very ornamental, especially Iris tuberosa and Iris xiphioides. The roots of Iris florentina are known in the shops by the name of orrice-root. 'There are but two British species, the one here described and the Stinking Iris, (Iris foetidissima, ) whose flowers are much smaller than the last, and of a dull livid purple; the leaves when bruised have a strong smell, hence it is called Roast-beef-plant in some of the southern and western counties, where it is very common. It flowers in May, in woods and pastures. 
Qualities and general Uses.-The leaves of this plant when fresh are eaten by goats, and in a dry state by cows, but are refused by horses and hogs. The root boiled in water, with the addition of copperas, has been used as a substitute for ink, and as a dye for woollen cloth. The flowers are said to afford a beautiful yellow dye. The seeds roasted resemble coffee. The leaves make excellent thatch, and are used for bottoms to chairs.

The root, or more correctly the rhizoma, is covered with a fleshy fragile parenchyma, of a greyish colour tinged with red. The odour of the plant in its recent state is lost in drying, but its taste is styptic and rather acrid, though somewhat insipid. It contains a brown extractive matfer, a fatty oil, which is acrid and bitter, and a small quantity of volatile oil, which concretes in shining flakes. Its astringent matter is extracted both by water and alcohol.

Medicinal Properties and Uses. - The expressed juice of the recent root is very acrid, and on being snuffed up the nostrils, produces a burning heat in the nose and mouth, accompanied with a copious discharge from those organs: hence it has been recommended as an errhine and sialogogue, and was used successfully by Armstrong * in obstinate head-ache and tooth-ache when other remedies had failed. 'The recent root also acts as a strong cathartic and hydragogue, and was administered with the best effects in a remarkable case of dropsy, by Ramsay $t$, and in ascites and anasarca by Plater. Lttmuller speaks of its vermifuge properties, and it has been used in the scrofula of children. Blair + recommends the clried root in diarrhœea and dysentery.

The dose of the expressed juice is from one to two draclims. The dried root is given in the quantity of a scruple to a drachm. Ettmuller mentions a preparation which enjoyed considerable reputation under the name of Nectar adstringens, in cases of vom iting of blood, dysentery, and and every other fiux or hæmorrhage. The root was for this purpose sliced; and, if succulent, the juice or the decoction was inspissated by further boiling to a thicker consistence; after which it was formed, by a sufficient quantity of sugar, into a syrup.

* Account of the diseases of children, p. 146.

+ In Med. Essays and Obser. Edinburgh, vol. v. pt. i. p. 93.

† Miscellaneous Observations, \&c., p. 78 . 


\section{LXXIX.}

\section{LINUM USI'TATISSIMUM.}

Common Flax.

Class V. Pentandria.-OOrder V. Pentagynia.

Nat. Ord. Linee.

Gen. Char. Calyx of five sepals, persistent. Petals five.

Capsule globose, mucronate, with ten valves and ten cells. Seeds ovate, compressed.

Spec. Char. Leaves alternate, lanceolate. Sepals ovate, acute, three-nerved. Petals crenate. Stem subsolitary.

\section{S Y N O Y M E S.}

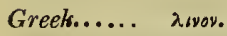

Latin.... $\left\{\begin{array}{l}\text { Linum sativum. Bauh. Pin. 214. Ger. Em. 556. Park } \\ \text { Theatr. 1335. } \\ \text { Linum sylvestre sativum. Raì Syn. } 362 . \\ \text { Linum. Hall. Hist. v. 1, 373. Fuchs, IIist. 471, c. 179. } \\ \text { Linum usitatissimum. Lin. Sp. Pl. 397. Eng. Bot. t. } \\ 1357 .\end{array}\right.$

French.... Lin; Lin commun.

Italian

$\left.\begin{array}{l}\text { Spanish and } \\ \text { Portuguese }\end{array}\right\}$ Lino.

German ... Lein.

Dutch.... Ulaszaadt; Wild Vlas.

Danish.... Hœre.

Swedish... Lin.

Bohem. and $\}$ Len.

Persian.... Tokemkutan.

Arabic.... Buzruk.

Hindostanie Tisi.

Sanscrit.... Atasi ; Uma.

Tamool.... Alleverei. 
Description,-The root is annual, small, and fibrous, producing a straight, slcnder, smooth, cylindrical, leafy stem, branched towards the summit, and rising about a foor and a half in height. The leaves are alternate, distant, lanceolate, generally acute, entirc, glaucons, three-nerved, and pointing upwards. The flowers are numerous, erect, on long unifloral, axillary, and terminal peduncles, forming a kind of corymb. The five sepals are persistent, ovate, mucronate, three-nerved, whitish and scariose at the margin. The petals are five, crenate at the point, obovate, shining, purplish blue, marked with deeper veins, and furnished with whitish claws. The filaments are five, subulate, erect, about the length of the calyx, united at the base in a hypopynous ring, from which proceed little teeth, opposite the petals, and indicating abortive stamens; anthers sagittate, two-celled, innate. The germen is ovate, surmounted by five capillary erect styles, as long as the filaments, and terminated by as many obtuse stigmas. The capsule is globose, obscurely five-sided, mucronate, ten-celled and ten-valved, dehiscing at the apex. The seeds are solitary in the cells, compressed, elliptical, acute, smooth, and shining. Plate 19, fig. 1, A. (a) the stamens; (b) germen and styles; $(c)$ the capsule cut transversely.

This plant is not unfrequent in corn fields and sandy pastures. It is common in Europe, as also in Nipaul and North America, and is said to have been introduced originally from Egypt. It flowers in $\mathrm{July}_{\mathrm{u}}$ and ripens its seed in September.

The generic name is derived from the Celtic Lin, thread; whence the Greek $\lambda$ เvov, the Latin linum, and other synonymes. The above species is called provincially Lint and Lyne.

There are about eighty species of Flax described, many of which are very ornamental and of easy cultivation. Four are natives of Britain.

Qualities and general Uses.-From the remotest antiquity this plant has been celebrated for its multifarious uses in the arts and domestic economy; but though indigenous to Egypt*, it does not appear to have been used by the natives of that country in the manufacture of cloth; the vestments of the mummies being uniformly of cotton. In later times, in our own country, when every little houselold prepared their own

* See Exodus, chap. ix. v. 31. 
garments, hemp and flax were assiduously cultivated. In the present day, very little is grown in England, as it exhausts the soil more than any other crop, and wheat is much more profitable. The seeds are chiefly imported from the Baltic. The cortical fibres or boon, separated from the woody matter, by maceration in water and various processes, forms the lint and tow which is spun into yarn and woven into linen cloth. The seeds bruised and mixed with honey, are used as food in some parts of Asia, and in times of scarcity have been employed in Holland for the same purpose; but they afford little nourishment, and are very difficult of digestion. The expressed oil is applied to many useful purposes, and the refuse or paste, called oil-cake, is a valuable food for fattening cattle, and for manure. The water in which the plant is immersed previous to separating the fibres has also a fertilizing effect upon the soil, but this water is of so poisonous a nature to animals, that the practice of macerating or steeping fax in any pond or running stream is, by the $33 \mathrm{~d}$ Henry VIII. c. 17, prohibited under severe penalties.

The seeds are inodorous, insipid to the taste, and abound in mucilage and fixed oii; the latter resides in the integuments, and is easily extracted by boiling water. M. Vauquelin found it to contain gum combined with an azotized matter, acetic acid, acetate and muriate of potass, with other salts, to which he attributes the diuretic properties of the seed. One hundred parts of linseed yield about twenty-two of oil, which for medical purposes should be expressed without heat.

Medicinal Properties and Uses. - The demulcent and purgative properties of linseed are mentioned by Hippocrates * and most of the other ancient writers. The aqueous infusion of the seeds has been much used to diminish the irritation of the urinary organs, also in angina, dysentery, pulmonary catarrhs, pleurisies, \&c. It has been strongly recommended in calculous affections accompanied with strangury or heat and frequency of urine, gonorrhœa, tenesmus, and other similar affections. Externally we find it adninistered with advantage as a lavement in colics and inflammation of the intestines and bladder; as a gargle in sore throat and in aphthous ulcers and ptyalism. The seeds bruised, or linseed meal as it is called,

- De Diæta, lib. ii. p. 356, et De Morb. Mul. lib. i. p. 603. 
boiled in water or milk, form poultices which are applied with the best effects to wounds and ulcers attended with pain and inflammation, and to all kinds of inflammatory swellings.

The oil is not so much used internally as it might be, on account of its unpleasant flavour, which is occasioned by the seeds being considerably heated previous to expression. When good it is a valuable demulcent and laxative. Sydenham*, Baglivi $\uparrow$, Gessner + , Tournefort $\S$, frequently administered it in cases of pleurisy; Michel \| in spitting of blood; Dodonæus qा, De Haen **, and Van Swieten ${ }^{*}+$ in ileus or twisting of the intestines; and Heberden ++ and Murray $\S \S$ speak of its efficacy in expelling worms. It is a valuable application externally to burns and scalds, mixed with lime water or oil of turpentine. By the speedy application of this remedy much pain is prevented, and the subsequent vesication greatly diminished. If turpentine be not at hand, any other spirit may be substituted. Frictions made with the oil upon hard tumours and sprains are often of service.

The infusion of the seeds is given in the dose of half an ounce to half a pint of boiling water, which may be previously sweetened with liquorice-root. The oil, taken in the dose of a table-spoonful at short intervals, gently purges; if likely to offend the stomach, a drachm of tincture of rhubarb may be added, or the following preparation may be used ||l|.

Take of cold-drawn oil of linseed, half an ounce;

Yolk of one egg;

Mix them gradually, constantly stirring till the oil is well incorporated, then add by degrees,

Syrup of buckthorn, .. three drachms;

Tincture of ginger, ... one drachm;

Peppermint water, .... one ounce.

This is a useful draught to be taken at bed time or early in the morning, by those who are subject to habitual costiveness.

- Opera cap. De Pleur. p. 265.

+ Opera, p. 38.

† Epist. lib. i. p. 39.

§ Voyage du I Levant, tom. ii. p. 140.

II In Journ. de Med. vol. xvii. p. 43.

T Prax. Med. p. 459.

* Mat. Med. P. ii. p. 204.

†† Comment. vol. ii. p. 147.

+† In Med. Trans. vol. i. p. 49.

$\S \S$ App. Med. tom. iii. p. 448.

III J. A. Waller, Brit. Bom. Herb. p. 156. 


\section{LXXX.}

\section{LINUM CA'THARTICUM.}

\section{Purging Flax, or Mill-Mountain.}

\section{Class, \&c.-See Common Flax.}

Spec. Char. Leaves opposite, oblong. Stem dichotomous above. Petals acute.

\section{S Y N ON Y M ES.}

(Linum pratense flosculis exiguis. Bauh, Pin. 214.

Linum sylvestre catharticum. Ger. Em. 560.

Latin.... \{ Chamælinum Clusii flore albo, sive L. sylvestre catharticum. Park Theatr. 1366.

Linum catharticum. Lir. Sp. Pl. 401. Engl. Fl. ii. p. 119. (Eng. Bot. t. 382.

French.... Lin purgatif.

Italian .... Lino purgativo.

Spanish.... Cantilagua.

Portuguese. - Linho purgante.

German... Purgierflachs.

Dutch..... Purgeer-Vlas.

Danish .... Liven vildhœr.

Swedish.... Vilhœr.

Description.-The root is annual, very small, woody, tapering, few-fibred, sending up several delicate, straight, round, smooth stems, bowed at the base, then upright and simple, dichotomous upwards, from two to six inches in height. The leaves are opposite, sessile, upright, elliptical, smooth, obtuse with a slight point, entire, glaucous beneath. The flowers are terminal, solitary, on long peduncles, forming a kind of panicle at the top of the stem, gracefully drooping before expansion. The sepals are ovate-oblong, acuminate, serrated, smooth, with a solitary nerve. The five petals are obovate, acute, spreading, 
white, deciduous. The five stamens have subulate filaments, arranged in a circle round the germen and tipped with roundish anthers. The germen is ovate, green, smooth, somewhat angled, with five capillary styles, and capitate yellow stigmas. The capsule is globose, invested by the calyx, pentagonal, tencelled and ten-valved, each containing a small, shining, oblong, pointed seed. Plate 19 , fig. 1 , B. (a) calyx; (b) stamens; (c) pistil ; $(d)$ fruit.

This plant is very common and often occurs in great profusion in pastures, flowering in June and July.

Qualities.-Purging Flax has scarcely any odour, but a bitter, sub-acrid, and nauseous taste. Water extracts the whole of its virtues, and the aqueous infusion is of a yellowish colour, inodorous, very bitter, and manifests its astringency by the black colour produced in it by sulphate of iron. Its cathartic property appears to depend on extractive matter and a bitter resin.

Medicinal Properties and Uses.-By the concurrent testimony of nearly all the old writers, this plant is a safe and effectual cathartic. Two drachms of the dried herb, infused in half a pint of water, is a convenient mode of exhibition; neutral salts or rhubarb may be combined with it. This is recommended by Linnæus * in incipient dropsy, and in affections of the kidneys and bladder. The vinous infusion is said to be more powerful, and in large doses to excite vomiting. An extract has been prepared, which operates rather severely in doses of ten grains. It may also be given in powder to the extent of a drachm, a little aniseed or cream of tartar being added. Its cathartic properties are well known to the peasantry, who infuse a handful of the recent herb in water or whey. 


\section{LXXXI.}

\section{ETHUSA CYNAPIUM.}

Common Fool's-Parsley.

\section{Class V. Pentandria.-Order II. Digynia.}

\section{Nat. Ord. U MbeLLIFERE.}

Gen. Char. Calyx obsolete. Petals obcordate, with an inflexed point. Fruit ovato-globose. Carpels with five elevated, thick, acutely-keeled ridges, the lateral ones marginal, and a little broader, girt by a somewhat winged keel. Channels with single vittæ. Seed semiglobose. - General involucre none; partial of three unilateral, drooping leaves..

Spec. Char. Leaves uniform; leaflets wedge-shaped, decurrent, with lanceolate segments.

\section{S Y N O Y M ES.}

(Ethusa minor, petroselino. similis. Bauh. Pin. 160.

Cicutaria tenuifolia. Ger. Em. 1063. Raii Syn. 215.

Latin...... Cicutaria fatıa. Lob. ic. ii. 280.

Cicuta minor sive fatua. Park Theatr. 913.

Coriandrum Cynapium. Crantz Fl. Austr. 221.

Ethusa Cynapium. Lin. Sp. Pl. 367. Eng. Bot. t. 1192.

French..... Ciguë des marais; Petite Cigüe; Faux Persil.

Italian..... Cicuta minore; Petrosemolo del cane.

Span. \& Port. Cicuta menor.

German.... Gartenschierling; Hundspetersilie.

Dutch...... Honds-petersilie.

Belgic ...... Kleine Dulle-kervel ; Wilde Eppe ; Wilde Petersilie.

Russ. ...... Medwjeschei koren.

Description.-The root is annual, slender, tapering, nearly white, with several creeping, filiform fibrils. The stem is erect, 


from twelve to eighteen inclies in height, branched, leafy, smootl, cylindrical, obscurely striated, shining, lurid green, with a dull purplish tinge at the base; flowering stems deeply and acutely furrowed. The leaves are uniform, bipinnate, the lowermost tripinnate, glabrous, lurid green; leaflets decurrent, rhomboid-lanceolate, lobed, and cut, rather obtuse, but with a short mucro at the point; petiole furrowed, slender, sheathing at the base, scarious. The flowers are disposed in terminal umbels of eight to fifteen nearly equal radii, spreading or slightly incurved; the umbellules small, distant. There is no general involucre, but a partial one of three unilateral, exterior, linear-subulate, drooping leaves*. The calyx is an obsolete margin. The five petals are small and white, obcordate, nearly equal, emarginate, with an inflexed point; the outermost somewhat radiant. The stamens are about as long as the petals, spreading between them, with thread-shaped filaments tipped with roundish anthers. The germen is ovate, furrowed, crowned by the yellow glandular disk, and terminated by two short recurved styles with obtuse stigmas. The fruit is yellowish brown, ovate, somewhat globose, of two carpels, which are marked with five acute ridges, of which the lateral ones are marginal, and a little broader, and bordered by a somewhat winged keel; each contains an ovate, plano-convex, brown seed. Plate 21, fig. 3, (a) the corolla, stamen, and pistil ; (b) the fruit, somewhat magnified; $(c)$ the same separating at maturity into two carpels ; $(d)$ the seed.

This plant is frequent in fields and gardens in this country and throughout the whole of Europe. It flowers from July to September.

The generic name is derived from $\alpha \cdot \theta w$, to burn, in allusion to its acrid taste. It has been called Cynapium, or Dog's-Parsley, as a mark of inferiority to the common Parsley; and Lesser Hemlock, in contradistinction to the true or common Hemlock.

Though sometimes confounded with the plants just men. tioned, Fool's-Parsley differs in several conspicuous characters. Being a common weed in rich garden soil, it has been inadvertently gathered for culinary Parsley, and has given rise to

- Before the flowers expand, these leaves or bractea are generally found spreading horizontally; when the plant is in flower they are quite pendent ; and in fruit, tending inwards. 
serious accidents : the leaves, lowever, are more elegant, drooping, acute, and of a lurid shining green, and when bruised have a disagreeable odour, appoaching to that of garlic; the flowers are white, and on one side at the base of each umbellule is a partial involucre of three long, acute, pendulous leaves, which furnishes a safe criterion when the plant is in flower. It is also often confounded, especially by herb gatherers, with the true hemlock, from which it differs in height, duration, unspotted stem, and fruit not waved at the ridges.

Qualities.-This plant has scarcely any smell in its recent state, but when bruised it exhales a nauseous odour resembling garlic, or the plant called Garlic Treacle-mustard (Erysimum Alliaria). The root has no particular taste. The fresh leaves somewhat resemble Parsley in flavour, but are destitute of the peculiar aroma of that herb; dried they have a nauseous, bitterish taste, their acridity having disappeared. The fruit* has all the properties of the herbaceous parts in a higher degree, and when chewed manifests a slight pungency in the gullet and stomach. Alcohol appears to be the best menstruum for the virtues of this plant. Professor Ficinus, of Dresden, has discovered in it a new alkaloid, to which he has given the name of Cynapin or Cynapia. It is crystallizable, and soluble in alcohol and water, but not in ether. The crystals are in the form of a rhombic prism, which is also that of the crystals of the sulphate $\dot{\dagger}$.

Poisonous Properties.-Orfila gave six ounces of the expressed juice to a strong dog, and tied the œsophagus. Twenty minutes after, the animal appeared nauseated, but some time elapsed before any urgent symptoms appeared. Suddenly he stretched out his limbs and lay on his belly. In a few minutes he tried to get up, but all his efforts were vain; the muscles of the limbs, the posterior especially, were powerless; he was raised up, but fell down again instantly. The organs of sense performed their functions; the pupils were scarcely dilated, and the pulsations of the heart were slow and vigorous. This state lasted for about a quarter of an hour,

* In this, as in several instances, the active principle resides in the integuments of the fruit, and not in the seed.

$\uparrow$ Philos. Mag and Annals, rol. ii. p. 392; British Association Report for 1831, 2, p. 510 . 
after which the extremities became convulsed, the organs of sense enfeebled, and the œsophagus and throat were the seat of spasmodic contractions. The stupor gradually increased, and the animal died at the end of an hour. On dissection, the heart was contracted and filled with blackish fluid biood, even in the left ventricle; the lungs were less crepitant than in their natural state; the stomach was full of the ingested juice, there was no alteration in the digestive canal *.

There are several cases recorded of the effects of this plant on the human body, which, if not exaggerated, prove it to be of a very deleterious nature.

"Two ladies of Castle Donnington, Leicestershire, partook of some salad wherein ÆEthusa Cynapium had been put by mistake for common parsley, with which it had been grown, and was gathered. Symptoms of an alarming kind soon followed, indicative of the full operation of that perni. cious vegetable. They were, a troublesome nausea, with occasional vomiting, accompanied with oppressive headache and giddiness; also a strong propensity to slumber, at the same time that calm repose was wholly prevented by frequent startings and excessire agitations. The mouth, throat, and stomach were impressed with the sensation of pungent heat, attended with great difficulty in swallowing. Increased thirst prevailed, with total loss of appetite for every kind of solid aliment. The extremities felt benumbed and were affected with tremors; and all the vital and animal functions were performed with unusual inactivity." + The ladies ultimately recovered.

" $\mathrm{A}$ boy six years old having eaten, at four o'clock in the afternoon, of this herb, which he mistook for parsley, soon uttered cries of distress, and complained of cramps in the stomach. Before his father had conveyed him from the field, his whole body was much swollen, and assumed a livid tint; his breathing was short and very difficult, and he died about midnight. Another boy, four years old, who was poisoned in the same manner was fortunately seized with vomiting; but this did not prevent the access of delirium. His life was saved, however, though the physician did not arrive till the next morning." +

A young man eat a handful of Fool's-Parsley, with nearly the same quantity of lettuce, about one o'clock at noon, on Thursday; in about ten minutes he was affected with pain and hardness in his stomach and bowels, attended with a rumbling. He walked out, but was seized with such languor, weariness, and weakness, that he could scarcely get home; giddiness and confusion of vision ensued; at seven o'clock he took an emetic;

* Traité des Poisons, tom. ii. p. 314.

+ Medical and Physical Journal, vol. xiv. p. 425.

$\mp$ Orfila, loco cit. 
this considerably relieved him from the uneasy sensations in the bowels, but the other symptoms continued, and he passed a restless night. Next day he had much pain in his head and eyes, which last were inflamed and bloodshot ; and transient, but painful, circumscribed swellings of the face. On Saturday his eyes were painful, and entirely closed by the surrounding inflammation; he was much relieved by bleeding. The symptoms were not entirely removed for two or three subsequent days, but he eventually recovered *.

Dr. Buckhave $\uparrow$ mentions several cases in which Fool'sParsley was given inadvertently for hemlock, and produced unpleasant symptoms, besides frustrating the purpose for which the conium was ordered. It occasioned tremors, vertigo, headache, colic pains, vomiting, loss of strength, and aversion to food; and, in some instances, convulsions. Riviere states that on opening the body of an individual who died from eating this plant, the tongue was black, a brownish serosity was found in the stomach, the liver was hard, and of a yellow colour; the spleen livid, but the body was not at all emphysematous $\ddagger^{\ddagger}$.

Hence it appears that Fool's-Parsley acts as a narcotic-acrid poison, and the symptoms may be thus summed up:the throat, thirst, vomiting, occasionally diarrhœa, short and difficult respiration, pulse small and frequent, headache, vertigo, swelling of the limbs, and delirium.

Treatment.-The first thing to be done in cases of poisoning by this plant is to administer an emetic; if it has been swallowed but a short time, two or three grains of emetic tartar, or from twenty to twenty-four grains of ipecacuanla dissolved in a small quantity of water is suitable; or the throat may be tickled with a feather. If the poison has been some time in the stomach, and spontaneous vomiting has not occurred, an emetic combined with a purgative, such as Epsom salts, may be given, and purgative lavements may be exhibited. If symptoms of cerebral congestion appear, blood should be taken from the jugular vein. Subsequently, when the poison is evacuated, acidulated drinks should be given, and chiefly water sharpened with vinegar, in small doses, frequently repeated. When the narcotic effects are abated, the acidulous drinks should give

* Mr. Lowe, in Stephenson and Churchill's Med. Botany, art. ZEthusa.

+ Acta Regiæ Societatis Mediox Hauniensis, vol. i.; quoted in Medical Commentaries, vol. xiv. p. 37 .

$\ddagger$ Orfila, l. $c$. 
place to mucilaginous infusions or decoctions, as the infusion of mallows or violets, or gum or almond emulsions. In the cases mentioned by Wittke * of two children, in whom there was complete insensibility, dilated, insensible pupil, and staring of the eyes, and in one of them frequent convulsions, the treatment consisted in the administration of milk, sinapisms to the legs, and cold sponging with vinegar.

Medicinal Properties and Uses.-Few of the ancient writers attribute any medical virtues to this plant; some of them, however, mention its resolvent and sedative effects when applied externally. It has been in many instances given, designedly or inadvertently, as a substitute for hemlock, and has produced untoward symptoms $\uparrow$. Nevertheless, we imagine that a plant endued with such peculiar and vigorous sensible qualities, nay one day become a useful remedy in the hands of the physician. To this end, experiments are necessary to ascertain more fully its properties, the doses in which it may be administered, and the indications it is calculated to fulfil.

* In Magazin für Pharmacie, xxxii. p. 228.

+ See the memoir of Dr. Buckhave, already quoted. 


\section{LXXXII.}

\section{DIGITALIS PURPUREA.}

\section{Purple Foxglove.}

\section{Class XIV. Didynamia.-Order II. Angiospermia.}

Nat. Ord. Scrophularinee.

Gen. Char. Calyx of five deep, unequal segments. $\mathrm{Co}$ rolla campanulate, ventricose beneath; limb obliquely four or five lobed, unequal. Capsule ovate, two-celled, many-seeded.

Spec. Char. Calycine segments ovate, acute. Corolla obtuse, its upper lip obscurely divided. Leaves ovatelanceolate, crenate, rugose.

\section{SYNONYMES.}

(Digitalis purpurea folio aspero. Bauh. Pin. 243.

Campanula sylvestris seu Digitalis. Tragus, 889 .

Digitalis purpurea vulgaris. Park Theatr. 653.

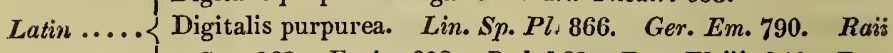
Syn. 283. Fuchs, 893. Dod, 168. Eng. Fl. iii. 140. Eng. Bot. t. 1297.

Digitalis speciosa. Salisb. Prod. 100.

French.... Digitale; Digitale pourprée.

Italian... . Digitale; Digitella; Guantelli.

Spanish .... Dedalera.

Portuguese. Dedaleria; Digital.

German.... \{ Fingerhut; Purpur Fingerkraut ; Fingerhutblume; WaldsDutch .... Vingerhoedkruid.

Danish.... Rod Fingerhut.

Swedish ... Fingerborrsœrt.

Polish .... Paluszniczek.

Russ. ... Naperstock.

Description.-The root is biennial, long, whitish, furnished with numerous slender fibres. The stem is erect, three or four 
reet high, cylindrical, simple, clotlied with fine down, leafy below, and terminated by the long spike of flowers. The radical leaves are large, ovate, spreading, with decurrent petioles; the cauline ones are somewhat decurrent, nearly sessile, and of an ovate-lanceolate or elliptical figure : the whole are alternate, wrinkled, veiny, crenate at the margin, of a dull cinereous, blueish-green above, lighter, downy, and reticulated beneath. The flowers are arranged towards the summit of the stem, in a long, pyramidal, elegant, spike, turned in one direction; each Hower pendulous, supported on a downy peduncle, subtended at the base by a small lanceolate leaf or bractea. The calyx is divided into five deep, ovate, ribbed, pointed segments, of unequal size; the uppermost smaller than the rest. The corolla is of a roseate-purple colour, silky, hairy and mottled within, ample, campanulate, inflated beneath, contracted at the base of the tube, divided at the limb into four or five shallow, oblique lobes, or into two lips, the upper of which is obtuse, slightly emarginate, and the lower with three projecting lobes. The stamens are didynamous, with declinate, thick, compressed filaments, the two longest crooked below, and inserted into the base of the tube; anthers large, yellow, with two deeply cleft, ovate lobes. The germen is superior, ovate, tapering, seated on a glandular ring or disk, surmounted by a slender style, with a bifid stigma, which is at first appressed, subsequently spreading. The capsule is ovate, acuminate, subtended by the persistent calyx, and tipped with the permanent style, with two cells and two valves, containing numerous small, sub-angular, dark brown seeds. Plate 20, fig. 2, (a) section of corolla opened to show the stamens; (b) germen, style, and stigma; (c) capsule cut transiversely.

This beautiful and stately plant, which may vie in elegance with many choice exotics, flourislies on dry banks, hilly pastures, and the borders of woods, especially in sub-alpine and rocky countries, hence it is almost unknown in the extreme eastern counties of England. It flowers in June and July.

The term Digitalis, from digitale, the finger of a glove, was applied to this plant by Fuchs, the first writer who mentions its medicinal qualities. This appellation was suggested by its German name, fingerhut, fingerstall, and beyond the idea of a glove no Euronean nation appears to have ventured. In France' 
it is sometimes called Gantelée, and Gants de Notre Dame, our Lady's gloves, viz. the Virgin. The English is the only language in which it is designated Fox's-glove; hence some have surmised that the proper orthography is Folks-glove, while Sir J. Smith expresses an opinion that it was originally called Fuchs'-glove. It is surprising that a plant so beautiful, and sufficiently striking to be introduced by painters in their landscapes, should not be alluded to by any of our old English poets, not even by Shakspeare, in whose time it was by no means uncommon, as appears from Gerard's Herbal, published in 1597. Some indeed have supposed it to be

$$
\text { " - long purples, }
$$

That liberal shepherdis give a grosser name,

But our cold maids do dead men's fingers call them,"*

mentioned by the queen when relating the manner of Ophelia's death, but from the connection of the passage we cannot acquiesce in such an opinion $\uparrow$.

Qualities.-The recent herb is inodorous, but when dried exhales a slightly narcotic odour, and is bitter and nauseous to the taste, accompanied with a kind of acrimony, which at first excites the flow of saliva, subsequently producing a dryness in the mouth, and an acrid sensation in the throat. These qualities are more or less energetic, according to the season $\neq$ in which the plant is gathered and the locality in which it grows. Both water and alcohol extract its virtues. The watery infusion has a pale olive-green colour, with the unpleasant odour and taste of the plant. It does not precipitate solutions of galls, and sulphate of iron only renders it of a darker colour; but it

- Hamlet, act iv. sc. 7 . .

+ The plant thus referred to, is generally supposed to be a species of Orchis, either the Orchis mascula or latifolia. Malone observes, "one of the grosser names Gertrude had particular reason to avoid:- the rampant widow."

‡ For medicinal purposes the leaves should be gathered when the plant is in full flower, and those of the second year which are completely developed and unwithered should be selected; those plants being preferred which grow in dry sunny localities. The stalk and midrib should be rejected, and the remaining part dried either in the sun or before a moderate fire, then reduced to powder, and kept in phials closely stopped and corered with black paper. The test of the goodness of the dried leaf is its beautiful green colour. 
produces a copious dark violet precipitate witlı nitrate of silver*. By distilling the aqueous extract Destouches obtained a considerable quantity of carbonate of ammonia; the presence of which is also detected in the dry powder, and in the tincture, which becomes milky by the addition of water. M. Leroyer, of Geneva, has succeeded in isolating the active principle of Foxglove, which he has named Digitaline. He treated the leaves first with cold ether and then with the same agent heated in a close stove. The extract procured by evaporating this tincture had a resinous appearance and an insupportably bitter taste, and produced a sensation of numbness on the tongue. It was then dissolved in distilled water, hydrate of protoxide of lead being added to neutralize the acid it contained, and evaporated to dryness. The product was again treated with highly rectified ether, and again evaporated. The residuum thus obtained was a brown heavy substance, very deliquescent, scarcely crystallizable, and extremely energetic. One grain of it killed a rabbit, without producing convulsions, in a few minutes $\downarrow$.

Poisonous Properties. - Cattle in general leave this plant untouched. Both the leaves and seed prove fatal to turkeys $\ddagger$; and a domestic fowl, to which the powder was given for some days together, experienced a remarkable loss of plumage $\S$. Mongiardini states that animals are more sensible of the deleterious effects of Digitalis, in proportion as their stomach approaches in structure to that of man. The celebrated Orfila has made several experiments on dogs with the dried leaves of Foxglove.

He gave six drachms of the powder to a strong dog and tied the resophagus. In two hours the animal made efforts to vomit, and foamed at the mouth; shortly after he was seized with vertigo, uttered plaintive cries, and laid down on his side. Three hours subsequently he was still able to walk, but staggered very much. These symptoms increased in intensity, and he died in the night. 'The stomach contained nearly all the powder ingested, and the mucous membrane was covered with bright red spots. The aqueous

- Thomson's Dispensatory, 1836, p. 336.

+ Magendie's Formulary, translated by Gregory, p. 201.

† Salerne, in Hist. de l'Acad. 1748, p. 84.

S Schienann, Diss. de Digitali purp. 31 ; see also Pennant, in Philos. Traus. vol. lxxi, P. i. p. 10. 
extract in doses of two drachms produced similar effects, accompanied in one instance with copious alvine dejections. In larger doses it occasioned, prior to death, tremors, convulsions, stupor, and coma. The resinous extract, prepared by treating the powdered leaves with alcohol, proved most energetic, and in all cases the effects were more rapid when the substance was applied to a wound, and more particularly so when injected into a vein. M. Orfila states that the movements of the heart were not in all cases slackened; sometimes they were accelerated, unequal, and intermittent *.

The action of this plant on the human subject is nearly the same as on animals, and several cases are recorded in which it has produced fatal consequences, both from the imprudent exhibition of excessive doses, and from its remarkable property of accumulating in the system, after moderate doses consecutively administered, and then suddenly producing constitutional effects. The following cases illustrate its poisonous character.

Dr. Henry, of Manchester, was called in to assist a female labouring under dropsy, who had taken an over-dose of Foxglove, prepared by boiling two handfuls of the leaves in a quart of water; of this decoction she had taken two large tea-cups full at seven A.sr. Before eight she began to be sick, and vomited part of the contents of the stomach. Enough, however, was retained to excite vomiting and retching throughout the whole of that and the following day, during which every thing that she took was rejected. In the intervals of sickness she was excessively faint, and her skin was covered with a cold sweat. The tongue and lips swelled, and there was a constant flow of viscid saliva from the mouth. Very little urine was voided on the day she took the Digitalis, and on the following day the action of the kidneys was entirely suspended. When Dr. Henry saw her, which was fortyeight hours after she had taken the poison, the tongue was white, the ptyalism continued, and the breath was fetid. The pulse was low, irregular, (not exceeding 40 ,) and very intermittent. She complained of general pains in the limbs and cramps in the legs. By the use of effervescing draughts and ammonia with ether, her previous state of health was gradually restored + .

Six ounces of a strong decoction of Foxglove leaves were administered to a young lad by an empiric, as a laxative for some trifling complaint. The patient took this dose early in the morning, and soon after was seized with sickness, vomiting, and severe pains in the bowels, followed by purging. Towards the afternoon he became lethargic, and slept profoundly several hours. At midnight he awoke with vomiting and colic, and in a short time he was attacked with general convulsions. A surgeon who saw him early in the morning found him violently convulsed, with the pupils dilated

* Traité des Poisons, tom. ii. p. 280, sqq.

† Ediuburgh Med. and Surg. Journal, vol, viii. p. 148. 
and insensible, and the pulse slow, feeble, and irregular. Coma quickly succeeded, and death took place twenty-two hours after the poison was swallowed. On examining the body, the external membranes of the brain were found much distended with blood, and the inner coat of the stomach was red in some parts *.

A man, affected with humid asthma, took a drachm of the powdered leaves in mistake for a grain. He was soon seized with vomiting, vertigo, and dimness and confusion of sight. The efforts to vomit were followed by the expulsion of a mucous and bilious matter, and were very frequent and violent, attended with great pain in the bowels, which was alleviated by lavements. These symptoms continued the whole of the following day, and the patient was much exhausted, with the pulse slow and irregular. The vomiting disappeared on the third day, but the pain in the abdomen continued, and he expectorated a thick and whitish matter. Opiates, aromatic infusions, and wine were administered, and he gradually recovered. The confusion of vision, however, remained for a fortnight, and immediately the effects of the poison disappeared, the cough and dyspnœa returned $t$.

Dr. Blackall states that one of his patients, while taking two draclums of the infusion of the leaves daily, was attacked with pain over the eyes and confusion, followed in twenty-four hours by a profuse watery diarrhœa, delirium, convulsions, insensibility, and an almost complete stoppage of the pulse. Although some relief was obtained from an opiate clyster, the convulsions continued to recur in frequent paroxysms for three weeks; in the interval he was forgetful and delirious, and at length he died in one of the convulsive fits $\ddagger$.

Treatment. - In cases of poisoning by Foxglove, as by other narcotico-acrid poisons, the offending substance must first be expelled by emetics or by the stomach-pump, unless spontaneous vomiting have occurred. An infusion of yellow bark (Cinchona cordifolia) has been recommended, to wash out the stomacli; subsequently, if the narcotic symptoms be urgent, cordials and stimulants, such as brandy, ammonia, and opium, may be administered, together with cold affusions, frictions, and blisters. In a case to which Dr. Beddoes $\$$ was summoned, he gave three grains of opium at two doses, an hour intervening between each; after which, he ordered fifteen drops of tincture of opium every hour in port wine, till the patient fell asleep. The next morning, the nausea still continuing, an injection containing sixty drops of laudanum was administered, and subsequently small doses of ipecacuanha and extract of hemlock.

* Edinburgh Journal, vol. xxvii. p. 223.

+ Villiers, in "Journal de Medecine," \&c., Novemb. 1817.

* Blackall on Dropsy, p. 173.

\$ Medical Facts and Observations, vol. v. p. 27. 
Medicinal Properties and Uses. - The action of this powerful plant upon the human frame is both stimulating and sedative*. In its former character, it excites the action of the digestive organs, the circulation, secretions, and nervous system. In small doses it will induce salivation, a free flow of urine, occasionally perspiration, vomiting, purging, and an increase in the frequency of the pulse. In strong doses it is followed by coldness of the limbs, vertigo, optical illusions, somnolency, delirium, and death.

Foxglove was first noticed by medical writers in the fifteenth century; it has been more or less used ever since, but from the above distressing and even fatal symptoms, which sometimes resulted from its exhibition, they were induced almost entirely to lay it aside. Fuchs, as before observed, was the first person who mentions it; it is also slightly alluded to by Gerard, and Parkinson + , a celebrated authority in his day, strenuously recommended it as an expectorant, and as a very effectual remedy, combined with polypody, against epilepsy ${ }_{+}^{+}$. He also speaks highly of its effects (the herb bruised, or an ointment made of the expressed juice) as an external application to scrofulous swellings. The use of Foxglove with the same view is also mentioned by Hermann $\S$, Bates $\|$, and Haller $\|$, and we be-

* Dr. Hallaran considers it rather a narcotic, as observable in its power over mania-first producing stimulating and afterwards sedative effects.

+ In this disease he ordered two handfuls of the leaves of Foxglove, and four handfuls of polypody (Polypodium vulgare) to be boiled in a sufficient quantity of beer; the decoction to be drunk twice a week. By these means he asserts that those who had been subject to epilepsy for twenty-six years, were either completely cured or had not a return of the complaint for fifteen months. The operation of this dose, as might be expected, being very violent, it could only be administered to the more robust.

"There is no doubt that its combination with the polypody contributes not a little to the anti-epileptic properties of Foxglove, and that in tbe hands of a skilful physician, that formidable disease might at length find a remedy in some of the more potent of the regetable productions. The combination above referred to promises fair to do much in the removal of the cause of that mysterious malady ; since polypody has a peculiar effect in dislodging from the intestinal canal that viscid slime which abounds in epileptic patients." J. A. Waller, Brit. Dom. Herb.p. 163.

₹ Theatre of Plants, p. 654 .

§ Cynosura, tom. ii. p. 467.

|| In Raii Hist. Plant. vol. i. p. 76j7.

q) Hist. Stirp. Helvet. n. 330. 
lieve it is still employed in rustic practice both to scrofulous tumours and ulcers. In Italy it has long been reputed an infallible vulnerary, hence their proverb-

\section{"Aralda chi tutte piaghe salda."*}

In modern practice Foxglove is rarely applied externally, but as an internal agent it is one of the most useful and powerful medicines contained in the Materia Medica. In addition to its reputed value in epilepsy and scrofula, it has not been without ample commendation against a variety of complaints; but to take a passing notice of its having been employed in active phlègmasiæ, measles, croup, \&c., we must observe that prudence warns the enlightened practitioner to abstain from its employment in acute phlegmasiæ of the skin, since the greater part of these cutaneous disorders tend naturally to a cure when their progress is not interrupted by unseasonable measures. Moreover, from the exciting quality of digitalis, the French authorities $\uparrow$ deem it inadmissible in primitive fevers, acute inflammations of the viscera, active hemorrhages, and in the majority of nervous and other affections attended with a general state of irritation. Dr. Clutterbuck + , however, recommends it in typhus, but it is not very generally prescribed. In this country it is now efficaciously used, as a sedative, in inflammatory affections; in active hemorrhages, particularly from the uterine vessels, when the pulse is sharp, throbbing, and frequent; in mania; and in most cases of increased vascular action, or in which it is essential to lessen the usual impetus of the blood, as in aneurism. In mania it acts as a narcotic, soothing the nervous system and producing sleep. Its internal use has also been extended with a view to dissipate enlargements of the sublingual glands $\oint$ and scrofulous tumours $\|$, and to improve the condition of scro-

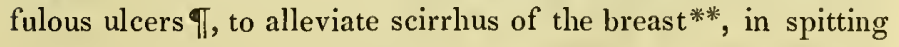

* "Foxglove cures all wounds."

+ Flore Miedicale, tom. iii. p. 163.

\# Inquiry into the Seat and Nature of Fevers, p. 429.

\$ Schiemann, Diss. de Digitali purpurea, p. 39.

\|I Merz, Diss. de Digitali purpurea, p. 8 .

T Darwin, in Med. Trans. vol. iii. p. 279.

** Kühn, in Richter's Chirurg. Bibl. vol. iv. p. 591. Also Mayer, Bilbl. cit. vol. v. p. 532. 
of blood *, jaundice $\uparrow$, chronic rheumatism, hooping-cough + , and other disorders.

The modus operandi of Foxglove is variously accounted for, but it appears most probable that its primitive action is stimulating, and that its sedative virtues are consecutive. By some writers, it is considered to exert a peculiar power over the heart, whereby the pulse is reduced both in power and velocity, but this quality is strongly denied by others, particularly by Dr. Saunders and Orfila $\S$. Its influence on the pulse is certainly extremely remarkable. Practitioners have known the pulse, in some cases, to fall to 50,40 , and even to 30 beats in the minute, while in other instances it has been raised from its natural standard to 120 or more $\|$. Dr. Saunders's experiments tend to prove that the primitive effect of digitalis was to augment the action of the heart, vascular circulation, and the secretions; that fever was the result of this increased action, and that the slackening and softening of the pulse was the consecutive or secondary effect depending on the indirect sedative influence of the remedy.

Notwithstanding its utility in affections of the heart has been questioned, Dr. Thomson remarks, "that experience has confirmed its efficacy in hypertrophy of the left ventricle, with or without dilatation of its cavity; it diminishes the action of the diseased organ, and with this the vertigo, pulsation of the head, singing in the ears, and other sympathetic affections of the encephalon attendant upon this state of the heart."

Another disease for which Foxglove is administered is phthisis, in which it is frequently beneficial as a palliative, and if taken in the incipient stage it may effect a cure $\mathbb{~}$. Its beneficial effects

- Jones, in Med. Comment. vol. i. p. 313.

+ Mrayer, in Rich. Chir. Bibl. vol. v. p. 533.

\# Thomson, Lond. Disp. 8th ed. p. 338.

$\$$ Orfila, Trait. des Poisons, tom. ii. p. 294.

II Dr. Baildon observed a curious effect of posture in ascertaining the real effects of digitalis on the pulse. When, by gradually increased doses, he took it to the extent of six grains in the day, the pulse fell from $\mathbf{J 0 0}$ to 40. But when it was actually at 40 , the erect position would raise it to 100 ; when sitting it was 72; and when lying down, 40 . He observed the same effect in several patients to whom he gave it. Edin. Med. and Surg. Journ. vol. iii. p. 271.

II Dr. Cox's Medical Botany, vol. ii. p. 104. 
in phthisis pulmonalis have been known above a century, and subsequent experience confirms the praises bestowed on it by a writer of that period*. Dr. Ferrier $\uparrow$ found its utility in this complaint much increased by combining it with myrrh and sulphate of iron. Whatever may be the measure of benefit derivable from Foxglove in the diseases already enumerated, it is more especially valuable as a diuretic. Dr. Withering + , who was the first to discover this property, employed it with complete success in numerous cases of dropsy, as have also other practitioners of established reputation. It is not, however, uniformly efficacious in all cases of dropsical effusion. "It seldom succeeds," says Dr. W., " in men of great natural strength, of tense fibre, of warm skin, of florid complexion, or in those with a tight and cordy pulse. If the belly in ascites be tense, hard, and circumscribed, or the limbs in anasarca solid and resisting, we have but little hope. On the contrary, if the pulse be feeble or intermitting, the countenance pale, the lips livid, the skin cold, the swollen belly soft and fluctuating, or the anasarcous limbs readily pitting under the pressure of the finger, we may expect the diuretic effects to follow in a kindly manner. Lastly, that if digitalis fails, there is but little chance of any other medicine succeeding." In the first state of constitution, the exhibition of squills, of cream of tartar, and other debilitating agents, or copious bleeding to effect a reduction of the strength, will frequently ensure its diuretic effects $\S$.

Although digitalis is now generally admitted to be a very powerful diuretic, and many cases might be adduced of its successful use, yet it is but justice to acknowledge that this medicine has more frequently failed|| than could have been reasonably expected $\pi$. These failures, we agree with Vassal in supposing, were not cases in which digitalis promised success; for although nothing is more indubitably efficacious in lessening

- Salmon; see Edin. Med. and Surg. Journ. vol. v. p. 303.

+ Essay on the Medical Properties of Digitalis.

$\ddagger$ Withering's Account of the Foxglove, 1785 .

$\S$ Stephenson's Med. Bot. art. xviii.

II Among the principal of the unsuccessful cases we may notice the eight fatal ones related in the Memoirs of the Medical Society of London, vol. ii. p. 145, by Dr. Lettsom.

I Woodville's Med, Bot. vol. ii. p. 220. 
the fluid in primary dropsies of the cellular tissue, chest, and abdomen, it has no effect in encysted dropsies and hydrocephalus.

Digitalis may be exhibited in the state of a powder, infusion, or tincture. Dr. Withering recommends a dose of one to three grains of the powder, or an ounce of the infusion, twice a day; the remedy to be continued in these doses till it either acts upon the kidneys, the stomach, the pulse, or the bowels *.

From the powerful and even fatal results which have followed the incautious use of this drug, it is very unfit for domestic use, and it can only be considered safe in the hands of experienced practitioners, and even by them, with great watchfulness. On the quantity and mode of administering it Dr. Murray $\downarrow$ makes some very judicious remarks, which, from their practical utility, are well worthy of the attention of the profession. "Though Withering," says Dr. M., " enjoined strictly the caution necessary in the use of Foxglove, the doses prescribed in his directions are perhaps rather large : and the propriety of the method which has sometimes been recommended, of progressively increasing the dose until the effects are obtained, is doubtful. If the dose be at first small, or at least, if having been raised to one grain of the powder, or one ounce of the infusion, twice in twentyfour hours, it be continued at this quantity, the diuretic operation will be obtained, in no long time, without any unpleasant symptom, and when it commences will continue of itself, even though the dose is suspended. Or if, from peculiarity of habit, or the state of disease, the dose requires to be increased, it ought to be done slowly, and witlout that regularly progressive augmentation which has been recommended. And if the effects begin to cease before the reduction of the dropsical swelling be completed, it may easily be renewed by a repetition of this moderate dose. This mode of administering Foxglove is that suggested by the nature of its action. The peculiarity which is charactersitic of it, is its tending to accumulate in the system, its effects not appearing for a time, but at length being suddenly induced. There is no necessity, therefore, to increase its dose, or to give one that is large, with the view of speedily inducing 
its action, since from its continued administration this will in no long time be established, and without that hazard which is otherwise incurred from this peculiarity in its operation."

The Pharmacopœias order an infusion and a tincture of digitalis, but owing to the careless manner in which the leaves are dried, there is great uncertainty in their operation. Dr. Thomson*, from experiments made, proposes ether as a vehicle for ensuring a preparation of a definite strength.

$$
\text { INFUSION OF FOXGLOVE } \dagger \text {. }
$$

Take of dried Foxglove leaves........ a drachm;

Boiling water........... half a pint.

Macerate for four hours in a lightly-covered vessel, and strain : then add half an ounce of spirit of cinnamon.

The dose is from half an ounce to an ounce, twice a day.

$$
\text { TINCTURE OF FOXGLOVE }+ \text {. }
$$

Take of dried leaves of Foxglove........ four ounces;

Proof spirit...............two pints.

Digest for fourteen days and filtre.

The dose of this tincture, which is the usual mode of administering Foxglove, is from three or four drops cautiously increased to thirty, forty, or more drops, according to the effect produced, and the capacity of the patient for bearing its operation. In conclusion, it is proper to observe, that many persons can bear much larger doses of the Foxglove than are here mentioned; but we cannot by any means recommend the use of so powerful a medicine in inexperienced hands; for which reason we have confined ourselves to the more common and safe doses, repeating again the absolute necessity of having a medical practitioner of experience to superintend and watch its progress.

* Thomson, Mat. Med. vol. i. p. 580.

+ Infusum Digitalis, Pharm. Lond.

‡ Tinctura Digitalis, Pharm. Lond. 


\section{LXXXIII.}

\section{FUMARIA OFFICINALIS.}

\section{Common Fumitory.}

\section{Class XVII. Diadelphia.-Order I. Hexandria.}

Nat. Ord. Fumariaces.

Gen. Char. Calyx of two deciduous leaves. Petals four, irregular, one of them spurred at the base. Silicle indehiscent, valveless, one-seeded ; style deciduous.

Spec. Char. Silicles globose, retuse; pedicels fruitbearing, erect, more than twice as long as the bracter. Leaves supra-decompound; leaflets wedge-shaped, cut, with linear-oblong lobes.

\section{SY NONYMES.}

Greek..... zatvos. Dioscorides.

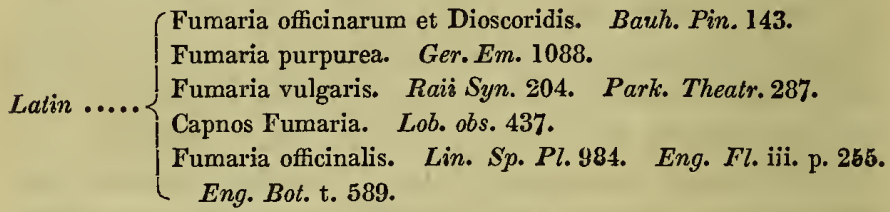

French.... Fumeterre; Fumeterre officinale.

Italian... . Fumosterno; Fumaria.

Spanish... Fumaria; Palomilla; Hiel deterra.

Portuguese. Fumaria.

German ... Erdrauch ; Gemeiner Erdrauch; Taubenkropf.

Dutch .... Duive-kervel ; Aard-rook ; Grysecom.

Danish ... Jordrog; Aakersissel.

Swedish.... Jordrœ.

Polish..... Rutha ptasza.

Persian.... Schahtra.

Japanese .. Fingosakf.

Arabic.... Bucklutulmeric.

Description.-The root is annual, slender, fusiform, whitish, and fibrous. The stems are slender, succulent, brittle, smooth, glaucous, erect or somewhat spreading, much branched, acutely pentangular, and from six to ten inches in length. The leares 
are alternate, petiolate, doubly or trebly winged, smooth, of a glaucous or cinereous green colour; the lobes plane, wedgeshaped, cut, with linear-oblong obtuse segments. The flowers are disposed in loose erect spikes opposite the leaves, with a lanceolate acuminate bractea at the base of each pedicel. The calyx consists of two lanceolate, acute, deeply toothed, deciduous sepals. The corolla is oblong, irregular, of a light rose colour, spotted with purple at the summit, composed of four irregular petals, the three upper connate at the base and spurred below the middle, the lower one linear, free, greenish. The filaments are combined in two parcels, each tipped with three small roundish anthers. The germen is superior, ovate, subcompressed, smooth, surmounted by a subulate deciduous style, the length of the stamens, and crowned with a capitate stigma. The fruit is a small silicle, smooth, globose, retuse and umbilicate at the tip, indehiscent, valveless, and containing a single seed. Plate 21, fig. 2, (a) corolla ; (b) calyx, stamens, and pistil ; $(c)$ the fruit; $(d)$ the same cut transversely ; $(e)$ seed.

This species of Fumitory is very common in cultivated fields, and by road-sides, in nearly the whole of Europe, whither it is supposed to have been introduced from $\Lambda$ sia or Greece. It flower's throughout the summer.

The generic name, derived from the Latin fumus, smoke, is said by Pliny to have been given in reference to the effects of the juice of this plant upon the eyes, causing a flow of tears as it were smoke*; but he seems to have borrowed this etymology from Dioscorides, who calls it $\tilde{x} \alpha$ tros, smoke. It has also been called fumus terrce, earth smole; which perhaps refers to the appearance of the foliage on a dewy summer morning, or as some suppose to its peculiar smell.

Qualities and general Uses.-Dambourney highly recommends fumitory as a substitute for Dyer's Rocket (Resedu Luteola) in dyeing. The plant is eaten by cows and sheep; goats dislike it, and horses totally refuse it.

The odour of the bruised plant is herbaceous; the taste disagreeable, somewhat saline and bitter, augmented by drying. It yields its virtues both to water and spirit. The aqueous infusion is bitter, of a reddish colour, and assumes a brownish-

* "Capnos... claritatem facit inunctis oculis, delachrymationemque ceu fumus, unde nomen." IIist. Iil). xxr. c. 13. 
black hue by the addition of sulphate of iron. The watery extract is bitter, slightly pungent and saline; the spirituous extract is simply bitter.

Medicinal Properties and Uses. - Fumitory, as already observed, was considered by the ancients very efficacious in diseases of the eves; Dioscorides* also speaks of its diuretic qualities; and succeeding writers attribute to it such various and important properties, that if not exaggerated would constitute this plant one of the first therapeutical agents. Galen, Aetius, Oribasius, Serapion, Avicenna, and Mesue, employed it in various obstructions, cachexia, and chronic diseases of the liver. Camerarius $\uparrow$, Hoffman $\ddagger$, Riviere $\S$, and Boerhaave $\|$ attribute to it the best effects in chronic affections of the viscera, hypochondriasis, and scrofula. It has been most celebrated, however, in jaundice, scorbutic complaints, and blotches and eruptions of the skin of the worst character $\rceil$. It exerts considerable influence on the sordes formed in the alimentary canal from impaired digestion, and which often gives rise to the above complaints. Leidenfrost highly recommends the expressed juice of Fumitory and Dandelion in obstinate cutaneous diseases.

The expressed juice, in the dose of two ounces twice a day, proves laxative and diuretic, and acts at the same time as a tonic; it may be taken alone or mixed with whey. It is applied externally to foul ulcers and eruptions of the skin. An extract is also made with the fresh juice, to be given in the form of pills, as well as a conserve and a syrup, which latter are readily taken by children. A decoction of the dried plant may be prepared as follows :-

\section{Take of Fumitory............ne handful; \\ Dandelion root ......... one ounce; \\ Liquorice root......... half an ounce; \\ Water................ne quart.}

Boil till one half is consumed and then strain. Of this a cupful may be given for a dose,

* "Herba in cibo sumpta copiosam bilem per urinas trahit." Mat. Med. 1. iv. c. 110 .

† Dissertatio de Fumariâ. Tub. 1718, p. 12.

$\ddagger$ Diss. de præst. remed. Domest. p. 30.

$\S$ Observat. cent. 3.p. 230.

II Hist. Plant. p. 388.

9 "I have found it useful in many cases in which bitters are prescribed; but its remarkable virtues are those of clearing the skin of many disorders. .... I have experienced its good effects in many instances of cutaneous affections which I would call Lepra." Cullen, Mat. Med, vol. ii. p. 77. 


\section{LXXXIV. \\ ALLIUM SATIVUM.}

Common Garlic.

Class VI. Hexanduia.-Order I. Monogynia.

Nat. Ord. Liliaces.

Gen. Char. Perianth inferior, petaloid, of six, ovate, spreading pieces. Spathe many-flowered. Capsule three-sided.

Spec. Char. Bulbs compound. Stamens three-pointed.

SY NON Y M E

Greek .... oroposov; ardisiov.

(Allium sativum. Banh. Pin. 73.

Latin.... \{ $\begin{aligned} & \text { Allium. Ger. Em. 178. Dod.671. Park. Parad. t. 51 J. } \\ & \text { Allium vulgare et sativum, Rait }\end{aligned}$

Allium sativum. Lin. Sp. Pl. 425.

French.... Ail ; Ail cultivé.

Italian.... Aglio.

Spanish.... Ajo.

Portuguese. Alho.

German... Knoblauch; Gartenlauch.

Dutch .... L. Look; Knoflook; Knoplook.

Danish.... Hvidlog.

Swedish ... Hwitlok.

Bav. \& Pol. Czosnek.

Russ...... Tschesnek.

Persian ... Sir.

Arabic ..... Sum.

Javanese... Bawany.

Sanscrit ... Lasuva.

Hindoostanie Lasun.

Description.-The bulb is nearly ovoid, with obtuse projections, covered with thin, membranous, reddish white integuments, beneath which are found several small bulbs, connected together and situated on a kind of plate or disk, from which proceed a number of descending fibres constituting the true root. The 
stem or floral peduncle is simple, cylindrical, smooth, about eighteen inches in height, with numerous long, flat, lanceolate leaves towards the base, fewer and shorter upwards. The flowers, arranged in a clustered umbel at the summit of the stem, are enveloped previous to expansion by a membranous spathe. The perianth is single and composed of six, white, ovate-oblong, spreading pieces. The stamens are six, alternately enlarged and three pointed, shorter than the corolla, and furnished with roundish anthers. The germen is superior, short, angular, and supports a simple style, terminated by an acute stigma. The capsule is short, broad, three-sided, three-valved, and threecelled, containing numerous roundish, dark-coloured seeds. Plate 20, fig. 4, (a) flower; (b) perianth, opened to show the stamens ; $(c)$ one of the alternate three-pointed stamens ; $(d)$ pistil.

This plant grows spontaneously in Egypt, Sicily, and Greece, and was first cultivated in the English garden about the year 1540. It flowers in July.

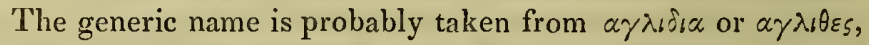
the terms by which the Greeks designated the cloves of garlic. According to Theis it is derived from the Celtic all, which signifies hot, burning.

The genus is extensive, comprising among others the great round-headed Garlic (A.Ampeloprasum) naturalized in England; the Leek (A. Porrum); Homer's Moly ( $A$. magicum); the Rocambole ( $A$. Scorodoprasum); Shallot (A. ascalonicum); Chives (A. Schønoprasum); Common Onion (A.Cepa); and Ramsons, ( $A$. ursinum) which is frequent in woods in this country, flowering in May and June.

Qualities and General Uses.-Garlic has been noted for its culinary uses from the remotest antiquity. The Egyptians were very fond of this vegetable, and were commonly reproached for swearing by the Garlic and onions in their gardens; an absurdity noticed by Pliny *, and by the keen satirist Juvenal $\uparrow$.

* "Allium cepasque inter Deos in jure jurando habet Egyptus."-Hist. lib. xix. c. 6.

+ "Quis nescit Volusi Bythinice, qualia demens

Egyptus portenta colit.

Porrum et cepe nefas violare aut frangere morsu ;

O sanctas gentes quibus hæc nascuntur in hortis

Numina!"-Sat. xr, v, 9. 
Its strong penetrating odour and eaustie taste, though peculiarly offensive to most English palates, is much relished by the Russians, Poles, Spaniards, and especially by the Jews. It is caten with bread, and employed by way of seasoning to various dishes. The juice of this bulb has bcen used in domestie economy for cementing broken glass and ehina.

The active properties of Garlie appear to depend on an essential oil, whieh is readily obtained by distillation with water : it is of a yellowish colour, of a thick and ropy consistence, and sinks in water. The expressed juice of the bulb yields a mucilaginous cxtract, albumen, fibrous matter, and water of vegetation. Sulphur, regetable albumen, and sugar have been detected in it, and the ashes furnish several salts of potass, phosphate of lime, oxide of iron, magnesia, lime, silica, \&e. Dried till it loses one half of its weight, it preserves all its sensible properties, but by coction in water or vinegar they are eomplctely destroyed, and a viscous mucilage is the result, which may be substituted, according to M. Bodard *, for gum arabic and tragacanth. The odour of Garlie is so penetrating and diffusible, that even the external application of it to the soles of the feet or any other part of the body will cause the lungs to exhale its odour, and the taste may be perceived in the mouth. It may be also detected in the flesh and even in the eggs of fowls, geese, \&c., that have eaten it.

Medicinal Properties and Uses. - Garlic is commended by Dioscorides $\downarrow$ as a remedy for tape-worm, venomous bites, hoarseness, coughs, obstructed urine, \&c., and externally for many cutaneous diseases. Cclsus \& directs it to be mixed with honey for inveterate coughs; he also speaks of its efficacy in preventing the paroxysins of intermittents, which is eonfumed by Rosen, Bergius $\$$, and others. It has enjoyed great reputation as a preservative against contagious diseases, more particularly the plague $\|$; hence it formed a principal ingredient in

* In Flore Medicale, tom. i. p. 30.

+ Mat. Med. lib. ii. c. 182.

† De Medicina, lib. iv. c. 4 .

$\$$ Mat. Med. tom. i. p. 255.

II See the authorities in Zorn. Botan. Med. p. 40 ; also Chenot de peste, p. 108 ; Diemerbroeck de peste, p. 164. Mr. Waller observes, "during the prevalence of a very contagious fever in the vicinty of Somer's Town and 
the "Four Thieves' Vinegar," and it was not less esteemed as a remedy when that fell disease had already commenced its ravages. Its utility as a diuretic in dropsy*, and as an expectorant in pituitous asthmas and other pulmonary affections unattended with inflammation, is also attested by numerous authorities $\uparrow$. It exerts a powerful influence on the urinary apparatus, assuaging nephritic pains, and facilitating the expulsion of gravel, and in calculous complaints generally it has proved remarkably successful +. As a prophylactic and remedy in scurvy, it has also been highly praised by Lind $\S$ and others. Its anthelinintic virtues are likewise considerable, as it kills the worms while still lodged in the intestines $\|$, which may be afterwards expelled by a cathartic.

The acrimony of Garlic has recommended it externally as a rubefacient. Sydenham $\|$ applied it bruised to the soles of the feet in cases of confluent small-pox, with the best effects. It has also been applied, bruised and mixed with olive oil or lard, to scrofulous tumours, parts affected with gont, burns, tinea or scald-head, and to remove warts. The juice rubbed on the spine of the back of children affected with hooping-cough, is said to be eminently beneficial; and inserted on cotton into the ear it is a favourite domestic remedy for deafness, ear-ache, and toothache.

"Dr. Bowles, an English physician, much celebrated in his time, employed Garlic as a secret remedy in asthma, and with considerable success. His method was to form a kind of preserve of the bulbs, or cloves, as they are

St. Giles's, the French ecclesiastics, who constantly used this plant in all their culinary preparations, visited hovels the most filthy and infectious with impunity, whilst the English ministers of the same religion were generally infected with the contagion, to which several of them fell victims." Brit. Dom. Herbal, p. 168.

* See the cases related by Forestus, Observ. lib. ix. obs. 27.-Bartho. linus, Hist. Anat. cent. ii. hist. 74.-Sydenham, Opera, p. 500.

+ Vide Mead, Monita et Præcep. p. 56. - Rosenstein (Hus-och Rese-apot. p. 87) recommends three or four cloves of Garlic, sliced, to be boiled in two pints of milk, with the addition of a little vinegar and honey, to be drunk warm, and repeated if necessary.

\$ See the experiments of Lobb. -De Dissolv. cal`. c. 10.

§ On Scurvy, p. 182-8.

\| See Bisset's Med. Cons. of Gt. Brit. p. 340 ; Rosenstein om Barns sjukd, p. 385.

T Opera, p. 378. 
called, by first boiling them till quite tender in a close vessel, then drying them carefully by means of a napkin. To the water in which they had been boiled, an equal quantity of the strongest vinegar was added, and to this as much refined sugar as was necessary to form a syrup, which was poured over the dried bulbs, put into an earthen jar, and carefully stupped for use. The dose was one or two of the bulbs to be taken in a morning, fasting, with one or two table-spoonsful of syrup. This remedy gained great repute for the cure of asthma, and it appears deservedly."*

Of the juice from half an ounce to two ounces, mixed with syrup or sugar, forms a dose. It may also be made into pills, with an equal quantity of soap, containing four grains each, of which four or five may be taken twice a-day. The offensive odour of Garlic may be in great measure counteracted by aromatics $t$, particularly the seeds of umbelliferous plants; baked beet-root has been affirmed to be very effectual for this purpose.

* J. A. Waller, Brit. Dom. Herb. p. 169.

† Noticed by Virgil :-

"Thestylis et rapido fessis messoribus æstu

Allia, serpyllumque, herbas contundit olentes."

Ecl. ii. 1. 11.

But Horace exclaims vehemently against it, after partaking of it at supper with Mæcenas:-

"Parentis olim si quis impia manu

Senile guttur fregerit;

Edit cicutis allium nocentiùs.

O dura messorum ilia !"

Epodes, lib. v. ep. 3. 


\section{LXXXV.}

\section{TEUCRIUM CHAM EDRYS.}

\section{Wull Germander.}

\section{Class XIV. Didynamia.-Order I. Gymnospermia.}

Nat. Ord. Labiate.

Gen. Char. Calyx tubular, five-toothed, nearly equal, or two-lipped. Corolla with the tube shorter than the calyx; upper lip bipartite; lower one spreading, trifid. Stamens much exserted; cells of the anthers confluent, spreading.

Spec. Char. Leaves ovate, deeply serrate, tapering into a footstalk. Flowers axillary, in threes. Stem ascending.

SYNONYMES.

Greek........ xauardęus.

Latin ..... $\left\{\begin{array}{l}\text { Chamædrys major (et minor) repens. Bauh. Pin. } 248 . \\ \text { Dod. } 43 . \\ \text { Chamædrys major (et minor) latifolia. Ger. Em. } 656 . \\ \text { Chamædrys vulgaris seu sativa. Raii Syn. 231. } \\ \text { Chamædrys vera mas. Fuchs, } 825 . \\ \text { Teucrium Chamædrys. Lin. Sp. Pl. 790. Eng. Fl. iii. } \\ \text { p. 69. Eng. Bot. t. } 680 .\end{array}\right.$

French..... Germandrée; Petit Chêne.

Italian..... Camedrio; Calamandrina; Querciola.

Spanish .... Camedris; Encinilla.

Portuguese .. Camedrio.

German .... Gamander ; Gamanderlein.

Dutch ...... Gamander; Bathengel.

Bohemian ... Kamanderl; Ozanka mennsj.

Swedish ..... Ekegrœs.

Polish ..... Ozanka.

Description. - The root is perennial, slender, yellowish, somewhat creeping, and furnished with short, delicate fibres. The 

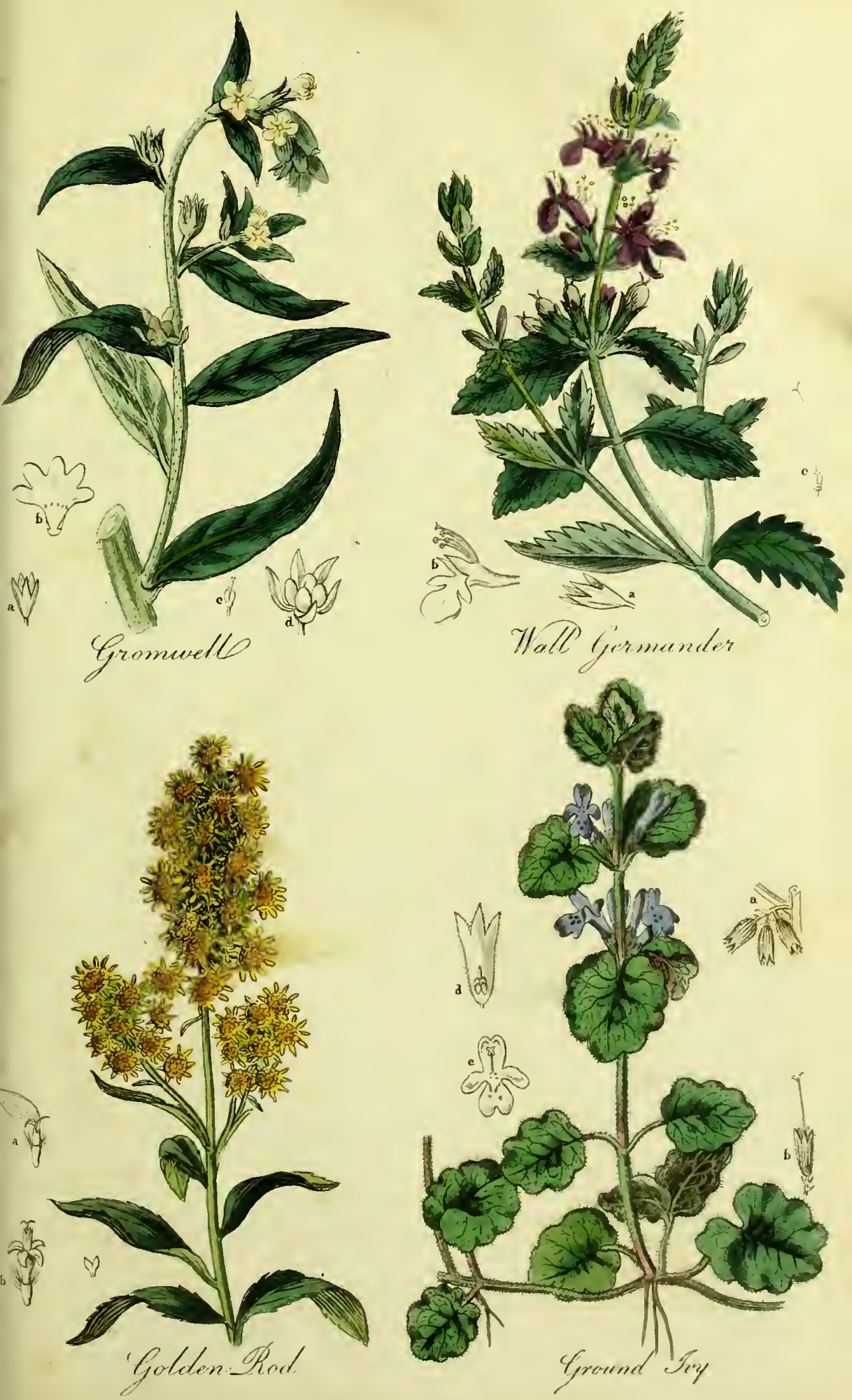

stems are branched, and decumbent at the base, then ascending, simple, obsoletely four-sided, hairy, and from nine incles to a foot in height. The leaves are opposite, shortly petiolate, obtuse, spreading, ovate, approaching to wedge-shaped, smooth, pubescent, veined, bright green above, paler beneath, deeply serrate at the margin, and sometimes slightly lobed. The flowers are supported on short peduncles, and are placed two or three together in the axils of the upper leaves, of which the uppermost, or bractea, are nearly entire at the margin. The calyx is angular, hairy, ovate-turbinate, with five, nearly equal, orate-acuminate, ciliate teeth, of a purplish hue. The corolla is reddish purple, much longer than the calyx, with a short, curved tube, and divided at the limb into two lips, of which the upper is short and bipartite, the lower one three-lobed, the middlc lobe large, roundish. The stamens are diclynamous, much protruded, with slender whitc filaments, terminated by simple anthers, with two confluent, spreading cells. The germen is four-parted, and from its centre rises a filiform style, longer than the stamens, surmounted by a bifid stigma. The fruit is composed of four achenia or small nuts, each containing a singlc seed, enclosed in the persistent calyx. Plate 22, fig. 2, (a) calyx; (b) corolla; (c) pistil.

This plant is a native of Britain, growing on ruined walls and by the borders of fields, but not common. It flowers in July.

Teucrium was the name given in honour of Teucer, prince of Troy, who, according to Pliny, was the first to discover tlic medicinal qualities of some plant allied to this. It is called Chamædrys from the Greek $\chi x u \alpha$, on the ground, and sous, an $o a k$, in allusion to the oak-like leaves; for the same reason it has obtained the names Quercula in Latin, Petit Chcine in Frencl, and Ground-oale in English. In the Herbier de Mayence, published in 1485, it is called Gamandié; lience the common French and English names of the plant.

T'he species most noted for their uses are the Wood Germander or Sage, (T. Scorodonia, frequent in woods in this country, distinguished by its cordate, wrinkled leaves, and one-sided racemes of yellowish flowers; Cat-Thyme Germander, ( $T$. Marum, ) a native of Spain, very aronatic ; Poly, (T'. I'olium, ) and the subject of the following articlc. 
Qualities and general Uses.--The physical qualities of this plant have recommended it as useful in tanning, in those countries where it abounds. It is eaten occasionally by sheep and goats, but is refused by other animals.

The odour of this plant is slightly aromatic, and the taste moderately bitter, diminished by drying. Both water and alcohol take up its active matter; the former most completely, the watery extract containing most of the bitter principle. The decoction is slightly aromatic and bitter; it assumes a greenish hue by the addition of syrup of violets, and a solution of sulphate of iron renders it dark and opaque. It contains a small portion of tannin, but its other constituents have not been examined.

Medical Properties and Uses.-Germander has been regarded as tonic, diuretic, sudorific, incisive, \&c., and has been highly commended in enlargements of the spleen, jaundice, obstructions of the viscera, suppressed menses, fevers, dropsy, asthma, and other chronic diseases of the lungs. It has also been employed in the expulsion of worms, and as a remedy in scrofula, scorbutic affections, and hypochondriasis, but more especially in gout. Vesale* mentions that Charles the Fifth was cured of gout by the vinous decoction of this and some other herbs, taken daily for sixty successive days. It was one of the ingredients in the celebrated antarthritic, or Portland powder + . Prosper Alpinus $¥$ states that the Egyptians employ it successfully in the cure of intermittent fevers, by taking a drachm of the powder an hour before the paroxysm; and Chomel $\S$ asserts that an infusion of this plant in wine, combined with the lesser centaury, has cured agues over which Peruvian bark had no power.

The infusion of an ounce of this plant in a pint of water, sweetened with honey or capillaire, has been recommended in asthmas $\|$, old coughs, \&c. For its tonic effects, in the diseases already mentioned, it may be employed in decoction with wormwood, lesser centaury, or chamomile.

* Epist. de Chinâ, p. 111.--See also Solenander, Consid. Med. sec. v. p. 475.-Sennerti, Opera, ed. Ludg. t. v. p. 568.

+ See p. 154.

† Med. Egypt. p. 316 .

$\S$ Plantes Usuelles, tom. ii. p. 139.

II As a remedy in this conplaint, Murray (A pp. Med. tom. ii. p. šl) con. siders it to agree with horehound; it is also allied to betony. 


\section{LXXXVI. \\ TEUCRIUM SCORDIUM.}

Water Germander.

Cluss, \&c. See Wall Germander.

Sipec. Char. Leares oblong, sessile, downy, serrated. Flowers few, axillary, stalked. Stem procumbent.

\section{S Y N O Y M E S.}

Greek..... oxogorov.

Latin .... $\left\{\begin{array}{l}\text { Scordium. Bauh. Pin. 247. Ger. Em. 661. Raii Syn. } 246 . \\ \text { Dod. Pempt. 126. Fuchs, 776. } \\ \text { Scordium legitimum. Park. Theatr. 111. } \\ \text { Teucrium Scordium. Lin. Sp. Pl. 790. Eng. Fl. iii. p. } 68 .\end{array}\right.$

French.... Scordium; Germandrée aquatique.

Italian.... Scordeo.

Spanish and $\}$ Escordio.

German... Knoblauchs gamander; Wasserknoblauch ; Skordienkraud.

Dutch.... Waterlook.

Danish ... Skordium; Løgsurt.

Swedish.... Gamander.

Polish .... Czosnkowc ziele.

Lithuanian Embutti.

Bohemian.. Wodnj czessnek.

Aratic.... Scordeon.

Description.-The root is perennial, creeping, and fibrons. The stem is procumbent, branched, quadrangular, hairy, and about a foot in length. 'I'he leaves are opposite, sessile, oblong, obtuse, downy, soft, nerved, deeply serrated, and of a light green colour. The flowers are few, mostly two in the axil of each leaf, pedunculate, and rather small. The calyx is tubular, hairy, striated, with five nearly equal, ovate, acute teeth. 'The corolla is small, and of a pale purple colour ; in other respects nearly resembling Wall Germander. Plate 23, fig. 2, (a) calyx; 
(b) corolla viewed sidewise; (c) the same in front; (d) pistil; (e) anther, magnified.

Water Germander grows in low wet meadows and marshy places in this country, but is rather rare. It has been found in Cambridgeshire, Oxfordshire, and a few other counties; and in Tipperary, Ireland. It flowers in July and August.

This plant was named Scordium from $\sigma$ rop $\delta$ rov, derived from oxopdov, garlic, on account of its alliaceous odour. According to Lobel *, it was first identified with the $\sigma x o p d$ rov of Dioscorides $\downarrow$, by Pelissier, Bishop of Montpellier, and Rondelet, professor of medicine at that place, about the year 1550. It has been called Garlic Germander.

The foliage is eaten by sheep and goats, but refused by horses, swine, and cows ; the latter, however, will eat it when pressed by hunger, in consequence of which, their milk is said to be imbued with the flavour of garlic. The herb placed among woollen garments defends them from moths, \&c.

Qualitres.-The herb exhales a peculiar odour, somewhat resembling garlic, but combined with an aroma approaching to that of hops. It is rather bitter and pungent to the taste, and becomes disagreeable and at length inodorous on being long kept. Both water and alcohol take up its active matter; the latter most perfectly, as appears from the greater bitterness of the extract, which contains a peculiar gum resin: the watery infusion is rendered black by sulphate of iron. Its aroma is thought to depend on an essential oil, which rises with the distilled water, according to Neumann + , but Lewis $\oint$ was not able to obtain it.

Medicinal Properties and Uses. - The most ancient writers on therapeutics attribute to this plant extraordinary virtues as an alexipharmic, sudorific, and antiseptic; with reference to the latter quality, Galen || asserts, that, on a field of battle, the

* Advers. p. 220.

+ Mat. Med. lib. iii. c. 125.

† Chym., vol. ii. P. iv. p. 195.

$\S$ Mat. Med., p. 596.

|| "Traditum est a quibusdam celebribus viris, cùm in prælio interemptorum cadavera multos dies insepulta jacuissent, quæcunque supra scordium fortè fortuna ceciderant, multos minus aliis computruisse, eâ presertim ex parte, quâ herbain attigerant." Galen de Antidotis, lib. i. c. 12. 
bodies which lay on these plants were much slower in putrefying than the rest; and from this fabulous relation its anti-putrescent character seems to have originated, and, most likely, its employment (with a host of other medicines) in the alexiterial and epidemic waters, Mithridatium, Theriaca, the diascordium of Francastorius*, \&c., as a specific against the plague $\uparrow$, contagious diseases in general, and gangrene. It has also been lauded in cases where there is want of tone in the stomach, and in flatulence, dropsy, anasarca, amenorrhœa, and humid asthma; likewise in various cutaneous diseases, and to expel intestinal worms. It has been applied as a topical stimulant in the form of cataplasm, fomentation, or in powder, to atonic ulcers and hospital gangrene.

Of the powdered herb, one or two drachms is a dose; and combined with some aromatic or opium, it forms a good remedy in chronic fluxes or diarrhœa. The infusion made by pouring a quart of water on an ounce of the recently dried plant, may be taken in doses of a cupful. It may also be made into a syrup, with one part of the herb and two parts of water, digested for two hours, then strained, and a sufficient quantity of sugar added. The distilled water has been given to the amount of one to three ounces, and the tincture is thus prepared :-

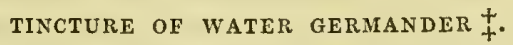

Take of Water Germander ......... three ounces;

Alcohol ................ sixteen ounces.

After digesting for three days, pour the liquid upon

Water Germander ........... two ounces.

Let them macerate for some time, then express and filter.

Excitant, reputed alexipharmic and diaphoretic.-Dose sixty drops.

- Hieronymus Francastorius was physician to Pope Pius III. (who died in 1553.)

+ See Diemerbroek de Peste, and Chenot de Peste. $l . c$.

* Pharmacopœia Wirtembergica. 


\section{LXXXVII. \\ SOLIDAGO VIRGAUREA. \\ Common Golden-Rod.}

\section{Class XIX. Syngenesia,_Order II. Polygamia SuPERfLUA.}

Nat. Ord. Compositre.

Gen. Char. Involucre closely imbricated, its scales connivent. Receptacle naked. Florets of the ray about five (yellow). Pappus simple, sessile.

Spec. Char. Cauline leaves lanceolate; lower ones elliptical. Racemes panicled, erect, crowded.

\section{S Y NONY M E.}

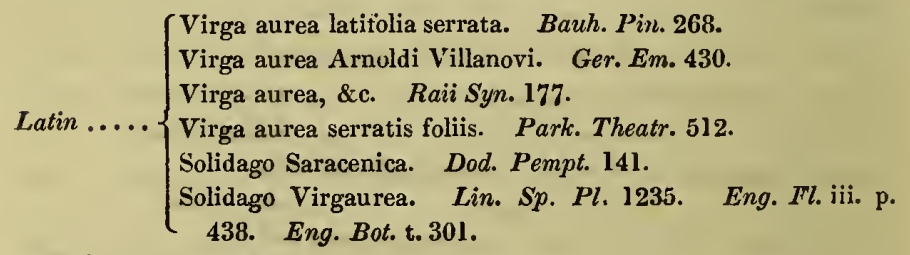

French.... Verge d'or.

Italian..... Verga d'oro.

Spanish... Vara de oro.

Portuguese. Vara d'oiro.

German ... Goldruthe; Heidenwundkraut.

Dutch .... Guldroede.

Bohemian... Swalnjk prostrednj.

Russ....... Solotoschnik.

Japanese .. Seubli.

Description. - The root is perennial, consisting of long simple fibres. The stem is leafy, angular, striated, rough, some- 
what downy, curved below, then erect, and from one to three feet in lengtl.. The leaves are alternate, acnte, sharply toothed, harsh, covered with short rigid down, slightly dotted above, paler beneath; the lower ones obovate or elliptical, on winged footstalks; the upper lanceolate, sessile, nearly entire. The flowers are produced in terminal and axillary clnsters, forming a panicled leafy raceme, very variable in compactness. The involucre is closely imbricated with scales, which are oblong, acute, downy, with a membranous border. The florets of the ray vary from five to ten, they are ligulate, three-toothed, pistilliferous, and of a bright yellow colour; those of the disk are numerous, perfect, tubular, with five equal spreading segments. The five filaments are liair-like, short, with the anthers united into a cylindrical tube. The germen is oblong, with a filiform style, and two revolute stigmas. The fruit is obovate, crowned with the sessile, hair-like pappus, which is rough when magnified. The receptacle is naked and nearly fiat. Plate 22, fig. 3, (a) floret of the ray magnified; $(b)$ floret of the disk magnified.

This plant is frequent in woods and thickets, on heaths and among furze in the British islands, and is common in most countries of Europe. It flowers from July to September.

The generic name is a derivative of solidari, to unite, because of the vulnerary qualities of the plant*. It was formerly called Solidago Sarracenica, and was said to have been brought over by the Christians who returned from the Saracen wars. It received its specific name from the Latin virga, a rod, aurea of gold, in allusion to its racemes of yellow flowers.

Qualities and general Uses.-Both the flowers and leaves of this plant are highly recommended by Bechstein as affording a yellow dye superior to that obtained from weld or dyer'sweed (Reseda Luteola). The foliage is eaten by cattle in general.

The odour of the recent herb when bruiscd resembles that of the wild carrot; and its taste is sub-astringent, bitter, and

* Gerard gravely informs us, that "Saracens Consound is not inferiour to any of the wound-herbes whatsoeuer, being inwardly ministred or outwardly applied in ointments or oyles. With it I cured Master Cartwright, a gentleman of Grayes Inne, who was grievosly wounded into the lungs, and that hy God's permission in shott space." Herbal, p. 429. 
slightly aromatic; these qualities it yields both to water and alcohol. The watery infusion is rather aromatic, herbaceous, and bitterish to the taste, and of a reddish hue, which is rendered dark brown by the addition of sulphate of iron, and does not redden litmus paper. The inspissated spirituous extract is stronger than the aqueous.

Medicinal Properties and Uses.-This plant was first brought into notice by Arnoldus de Villa Nova *, who highly extolled it as a remedy for stone in the bladder, and for its vulnerary qualities $\uparrow$. Barclaius, Solenander, Piso, and others, relate instances of its good effects in gravel and other diseases of the

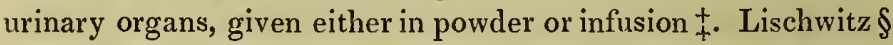
asserts that an ulcer of the urethra was completely cured by means of this remedy ; and Ettmuller considered it very useful in ulcers and wounds of the bladder. Hoffmann \| recommends it in hectic fever, incipient dropsy, and obstructions of the viscera. Although quite neglected in the present day it is certainly not inert as a medicine, and may be found useful in cases where astringents are admissible, as in chronic diarrhcas, dysenteries; and externally in ulcers of the mouth and throat, putrid gums, \&c. It may be taken in infusion or decoction, at pleasure; an extract and a tincture may also be prepared from it.

* Opera, p. 1266.

+ Gerard had a very great opinion of it as an application to bleeding wounds and ulcers, and he gives the following apposite account of its disuse : "I haue known the dry herbe which came from beyond the sea sold in Bucklersbury for halfe a crowne an ounce. But since it was found in Hampstead wood, euen as it were at our townes end, no man will give halfe a crowne for an hundred weight of it; which plainely setteth forth our inconstancie and sudden mutabilitie, esteeming no longer of anything how pretious soeuer it be, than whilest it is strange and rare."-Herbal, p. 430.

¥ Murray, App. Med. vol. i. p. 258.

$\S$ Diss. de Virg. Aureis, p. 87.

|| Med. Off. p. 238. 


\section{LXXXVIII.}

\section{CHENOPODIUM OLIDUM.}

Stinking Goosefoot.

Class V. Penntandria,-Order II. Digynia.

Nat. Ord. Chenopodea.

Gen. Char. Perianth single, inferior, five-cleft, persistent, embracing the fruit. Seed solitary, orbicular.

Spec. Char. Stem diffuse. Leaves ovate-rhomboid, entire. Flowers in dense, clustered, axillary spikes.

\section{SYNONYMES.}

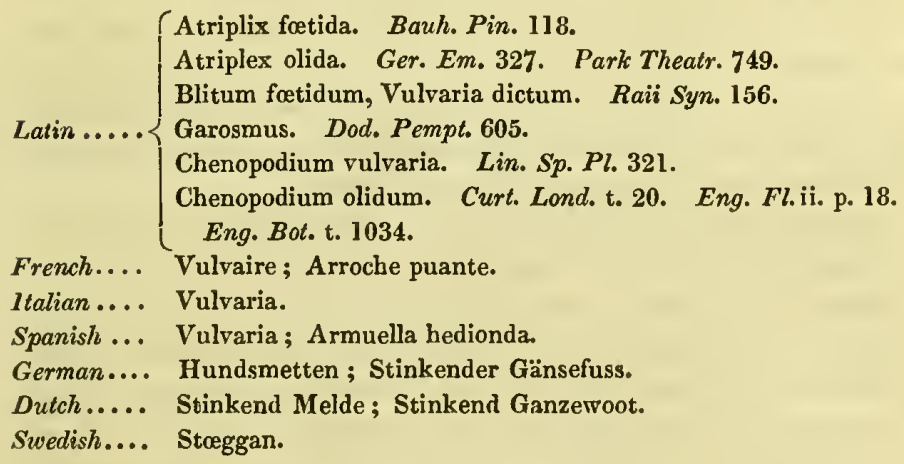

Description.-The root is apnual, small, and fibrous. The stems are diffuse, channelled, with procumbent branches, and from six to twelve inches in length. The leaves are numerous, small, ovate, approaching to rhomboid, entire, greasy to the touch, and covered with a greyish, pulverulent, fetid substance. The flowers are very small, of a light greenish colour, and arranged in dense clustered spikes in the axils of the leaves. 
The perianth is single, inferior, deeply divided into five, ovate, concave, permanent segments, membranous at the edges. The stamens are five, with subulate filaments, and roundish twolobed anthers. The germen is globose, supporting two short styles, terminated by obtuse stigmas. The fruit is globose, depressed, clasped, but not entirely enveloped by the persistent calyx, and contains a single lenticular seed. Plate 21, fig. 4, (a) the flower ; (b) the fruit.

This plant grows in waste places and near walls in the vicinity of towns, especially near the sea, and is a native of Europe, from the south of Italy to Sweden. It flowers in August.

The generic name is derived from $\chi^{\gamma \nu}, \chi^{\gamma}, 0 s, a$ goose, and Tous, a foot, in allusion to the shape of the leaves in some of the species. It has also been called Garosmus and Vulvaria* from its fetid smell.

Qualities.-The odour of the recent plant is extremely fetid, resembling that of putrid fish; the taste is herbaceous and nauseous. It gives a strong impregnation to water both by infusion and distillation; its active matter is also extracted by alcolool. It contains a large portion of subcarbonate of ammonia and nitrate of potass, albumen, osmazome, an aromatic resin, a bitter matter, and acetate, phosphate, and tartrate of potass. Clievallier mentions the remarkable fact that it exhales pure ammonia during its whole existence. The ashes yield a large quantity of potash.

Medicinal Properties and Uses.-This plant was celebrated by many of our old physicians for its efficacy in hysterical diseases. Needham $\uparrow$ recommends the leaves to be made into a conserve with sugar as a remedy in hysteria, and Fuller + with the same intention prepared his Electuarium hystericum, with four ounces of the conserve and forty-eight drops of oil of amber; a piece to be taken the size of a chestnut. Tournefort $\S$ commends a spirituous tincture of the plant. Dale \| has the following observations on it, "uterina est, menses provocat, fotum mortuum secundinamque expellit, in hystericis multum

* "Vulvaria allicit canes ut mingant in eum qui portat."-Linnaus.

+ In Kaii Hist. Plant. vol. i. p. 198.

† Pharmacopœia Extemporanea, (ed. v.) 1740, p. 109.

$\S$ Hist. des Plantes de Paris, tom. i. p. 30.

If Pharmacologia, p. 75. 
prodest;" and Cullen* speaks highly of its antispasmodic qualities. It has since relapsed into oblivion, until Mr. Houlton, an enterprising and skilful practitioner, a short time ago, directed his attention to its valuable properties, and from his investigations it appears to be one of the very few medicines which can properly be styled emmenagogue. He directs the infusion to be carefully evaporated in vacuo, to a proper consistence to form into pills, in which state it is not offensive to the palate or stomach: the dose is from ten to fifteen grains, twice a day. In several cases of suppressed menstruation it has been eminently successful, especially in pale and cachectic patients.

* Mat. Med. vol. ii. p. 365 


\section{LXXXIX.}

\section{LITHOSPERMUM OFFICINALE.}

\section{Common Gromwell.}

Class V. Pentandria.-Order I. Monogynia.

Nat. Ord. Boraginee.

Gen. Char. Calyx in five deep segments. Corolla funnel-shaped; orifice naked. Anthers included. Stigma obtuse, bifid.

Spec. Char. Stem erect, much branched. Leaves broad, lanceolate, acute, veiny. Corolla scarcely longer than calyx. Nuts smooth.

\section{S Y NON YMES.}

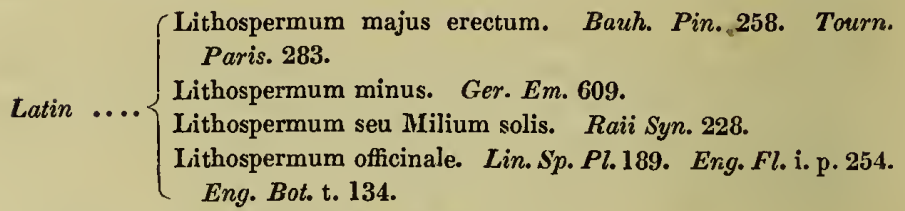

French.... Gremil ; Herbe aux perles.

Ital.\&Span. Lithospermo.

Portuguese. Aljofar.

German ... Steinsame.

Dutch .... Paarlkruid ; Steenbreek ; Steenzaad.

Danish .... Steenklinte.

Swedish .... Stenfrœ.

Description.-The root is perennial, woody, tapering, whitish, and fibrous. The stem is erect, cylindrical, branched, beset with short rigid hairs, and from twelve to eighteen inches high. The leaves are alternate, sessile, acute, nerved, rough above, hairy beneath, and of a greyish green colour. The flowers situated towards the summit of the branches are small, axillary, and supported on short peduncles. The calyx is cleft into five deep segments, which are narrow, acuminate, and hairy. The corolla is funnel-shaped, of a pale yellow colour, its orifice 
naked; tube short; limb divided into five obtuse segments. The stamens are five, with oblong anthers, included in the tube. The germen is four-parted, with a filiform style, and a bifid, obtuse stigma. The fruit consists of four, hard, polished, wlitish brown nuts, (seldom more than two or three coming to maturity,) seated in the persistent calyx. Plate 22, fig. 1, (a) calyx ; $(b)$ corolla opened ; $(c)$ pistil ; $(d)$ fruit.

Common Gromwell is frequent in dry and uncultivated places, especially in gravelly and calcareous soil. It flowers in May and June.

The generic name is formed from $\lambda \cdot \theta 05$, a stone, and $\sigma \pi \varepsilon p \mu x$, a seed, on account of the stony hardness of the nuts *. In like manner Gromwell is derived from the Celtic graun, a seed, and mil, a stone. It is also called Greymill and Grey Millet.

Qualimies.-The nuts have no smell and merely a farinaceous taste. Grew $\uparrow$ states that the stony shells produce effervescence in powerful acids, but other observers have not confirmed this. The shells afford a considerable portion of pure silica, sulphate of lime and iron. The seeds contain a small quantity of oily matter, but in other respects nearly resemble the cereal grains, for which they have even been proposed as a substitute.

Medicinal Properties and Uses.-The lithontriptic virtues of these nuts appear to have been deduced from the fallacious doctrine of signatures; their stony consistence being accounted typical of their efficacy as dissolvents of stone in the liuman bladder. Modern writers, though they attach no credit to these illusory qualities, consider the seeds as diuretic and useful in emulsion, in cases where there is strangury or heat of urine, gonorrhœa, \&c. Externally the decoction of the seeds or roots, applied hot, is recommended for relieving pain in the urinary and genital organs, and in the sequel of difficult or painful labours. According to Haller $\ddagger$ the whole herb is narcotic.

- Pliny considered them as one of the greatest curiosities in the vegetable world:- "Nec quicquam inter herbas majore quidem miraculo aspexi. Tantus est decor velut aurificum arte alternis interfolia candicantibus margaritis ; tam exquisita difficultas lapidis ex herba nascentis." -IIist. lib. xxvii. c. 11.

+ Mixt. colp. p. 22.

$\ddagger$ Hist. Stirp. Hclv. n. 595 . 


\section{$\mathrm{XC}$. \\ GLECHOMA HEDERACEA.}

Ground-Ivy.

Class XIV. Didynamia.--Order I. Gymnospermia.

Nat. Ord. Labiate.

Gen. Char. Calyx tubular, many-nerved, with five nearly equal teeth. Corolla with the tube exserted; upper lip bifid; lower lip three-lobed, the middle lobe large, plane, emarginate. Anthers before bursting cohering in pairs, in the form of a cross.

SPEC. Char. Leaves reniform, crenate.

S Y NON YMES.

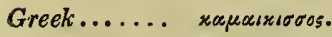

Hedera terrestris vulgaris. Bauh. Pin. 306.

Hedera terrestris. Ger. Em. 856. Raii Hist. 567. Park.

Latin ...... Theatr. 677.

Calamintha humilior folio rotundiore. Raii Syn. 243.

Glechoma hederacea. Lin. Sp. Pl. 807. Eng. Fl. iii. p. 88. Eng. Bot. t. 853.

French .... Lierre terrestre; Terrette.

Italian..... Edera terrestre; Ellera terrestre.

Spanish....... Yedra terrestre.

Portuguese... Eira terrestre.

German...... Gundermann ; Erdepheu.

Dutch....... Hondsdraf ; Aardveil ; Onderhave.

Danish....... Jord Vedbende.

Swedish...... Jordrefwa.

Description.-The root is perennial, small, fibrous, and creeping, sending out long runners. The stems are creeping, with upright branches, slender, quadrangular, rather hairy and about a foot in height. The leaves are opposite, petiolate, downy, reniform, nearly round, crenate; the petioles of the lower leaves are long, channelled, hairy and spreading. The flowers are disposed three or four together in the axils of the leaves on short peduncles, at the base of which are a few 
subulate bracteæ. The calyx is short, tubnlar, striated, hairy, with five nearly equal acuminate teeth. The corolla is purplish blue, bilabiate, with the tube much longer than the calyx; the upper lip bifid, erect; the lower lip three-lobed, the middle lobe large, enarginate, variegated near the palate, the side lobes narrower and shorter. The stamens are didynamous, covered by the upper lip, with whitish anthers, approaching so as to form a cross. The germen is ovate, fourcleft, surmounted by a filiform curved stylc, terminated by a bifid acute stigma. The fruit consists of four akenia or small nuts enclosed within the persistent calyx. Plate 22, fig. 4, (a) the fruit; $(b)$ the calyx and pistil ; $(c)$ corolla seen in front; $(d)$ the calyx opened to show the four-parted germen.

This plant is very common under hedges, by old walls and waste places, and is a native of Europe from Italy to Sweden. It flowers in April and May.

The name Glechoma is derived from $y \lambda r$ r wor, given by the Greeks to a species of mint. This species was formerly called Hedera terrestris, as now Ground-Ivy, from a similarity in the form of the leaves to those of common Ivy, (Hedera Helix,) and probably with some allusion to the odour of the two plants. It has received the vernacular names of Alehoof, Tunhoof, Gillgo-by-the-ground, and Cat's-foot.

Qualities and general Uses. - Ground-Ivy has been used to clarify and preserve malt liquors, for which purpose it was much employed formerly*. Cows, swine, and goats refuse it, but sheep are fond of it, and horses eat it occasionally. It has been recommended as food for silk-worms.

This plant has a strong and aromatic odour when bruised, and is slightly acrid, warm, and bitter to the taste. It contains a small quantity of volatile oil $\uparrow$, which rises in distillation, with water. "Water extracts all its virtues by infusion, and on inspissating the filtered liquor only the unpleasant smell of the herb exhales, its more valuable part remaining concentrated in the extract, which to the taste is at first sweetish, then bitter,

* Hence the names Alehoof and Tunhoof, and the house at which such medicated beverage was sold was called gill-house.

+ This substance is contained in small glandular dots which beset the under surface of the leaves. 
and subsequently very pungent." * Sulphate of iron speedily blackens the aqueous infusion.

Medicinal Properties and Uses.-Ground-Ivy ranks among those plants which have been at one time extravagantly lauded and at another unduly neglected. Its properties have been described by different authors as tonic, stomachic, aperient, diuretic, expectorant, vulnerary, errhine, \&c., and it was hence considered a potent remedy in pulmonary + and nephritic $\ddagger$ complaints, dropsy, dyspepsia, hypochondriasis, and colic. It is still resorted to by the poor for the cure of obstinate coughs; they use it in the form of tea sweetened with honey, liquorice, or sugar, and frequently experience its beneficial effects. In the early stage of consumption the free use of the infusion has been strongly recommended, and for its sedative qualities it has likewise been employed in cases of insanity and melancholy with decided benefit. Mead $\S$ speaks of its being usefully joined with fermenting ale, in gravel and other diseases of the kidneys. Ray $\|$ asserts that the expressed juice snuffed up the nostrils, has cured the most violent and inveterate headaches.

It may be given in substance in the form of powder, or in pills, or suspended in any convenient liquid, to the amount of two or three scruples. Of the expressed and clarified juice (which is the best form) a wine-glassful may be administered twice or thrice a day. The infusion $\int$ in water, either alone or with the addition of elecampane leaves and liquorice root, may be taken at pleasure. The conserve and syrup have not much efficacy, but the extract is a good substitute for the expressed juice.

- Lewis, Mat. Med. p. 300.

+ Willis, Pharm. rat. sect. 1. c. 6.-Morton, Phthisiologia, lib. iii. cap. 5. Riv. Prax. P. 1. p. 349._Ettmuller, Opera, t. i. p. 580. (ed Westphali.) Scardona, Aphorismi, lib. ii. p. 69.-Sauvages Nosol. t. iii. p. 2. cap. De phthisi.

† Pauli Quadrip. bot. p. 74.-Sennertus Opera, t. iii. p. 576.-Plater Prax. tom. ii. p. 499._Revsn. Obs. med. p. 90. apud Welsch.

$\S$ Monita et præcep. med. p. 97.

II Hist. Plant. tom. i. p. 567.

9 The Dutch, by repeated infusions of the plant in gin, make a kind of tincture which they esteem very efficacious in the gravel. 


\section{XCI.}

\section{AJUGA CHAM估PITY.}

\section{Ground-Pine.}

\section{Class, \&c.-Dee Bugle.}

Spec. Char. Stem diffuse, hairy. Leaves tripartite, with linear, entire segments. Flowers axillary, solitary, shorter than the leaves.

\section{S Y NON Y M E S.}

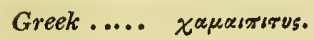

Chamæpitys lutea vulgaris seu folio trifido. Bauh. Pin. 249.

Chamæpitys mas. Ger. Em. 525.

Latin...... Chamæpitys vulgaris. Raii Syn. 244. Park Theatr. 283.

Teucrium Chamæpitys. Lin. Sp. Pl. 787.

Bugula Chamæpitys. Scop. Carn. 718.

Ajuga Chamæpitys. Eng. Fl. iii. p. 67. Eng. Bot. t. 77.

French.... Ivette; Ivette commun.

Italian.... Camepizio.

Spanish.... Camepitios; Pinillo.

Portuguese. Chamepite.

German.... Schlagkraut; Feldcypresse; Erdweihrauch.

Dutch .... Veld cypress.

Bohemian.. Ywa; Polnj cypris.

Polish .... Iwinka; Piznowa.

Description.-The root is annual, descending, somewhat branched, and fibrous. The stems are several from the same root, spreading, branched, leafy, quadrangular, of a reddishpurple colour, clothed with whitish hairs, and from six to twelve inches in height. The leaves are placed in pairs at the joints of the stem, and are sessile, hairy, about an inch long, and of a yellowish-green colour, three-parted to the middle, with linear revolute segments; the lowermost broader and nearly entire. The flowers are sessile, solitary, and axillary, shorter than the leaves. The calyx is ovate-turbinate, hairy, 
five-cleft; the segments erect and acute. The corolla is bilabiate, of a yellow colour spotted with red; the tube longer than the calyx; the upper lip very small, bifid, erect; the lower elongated, trifid, the middle lobe largest, emarginate, obtuse. The stamens are didynamous, bent towards the upper lip. The germen is superior, four-parted, with a setaceous style, longer than the stamens, and an acute stigma. The fruit consists of four achenia, or small nuts, enclosed in the persistent calyx. Plate 23, fig. 1, (a) calyx; (b) corolla; (c) stamens ; (d) pistil.

This plant is not uncommon in sandy and gravelly fields in the eastern parts of England, especially in Kent. It is a native of the south and middle of Europe, Palestine, Southern Africa, and Virginia, flowering in April and May.

Chamæpitys *, the name by which this plant has been long known, is derived from $\chi^{\alpha \mu \alpha}$, on the ground, $\pi i \tau \cup \varsigma$, a pine, from the resemblance it bears in the form of its leaves and its balsamic smell to the pine tree. It has been called provincially Herb-ivy, Field-cypress, and Forget-me-not.

QunLities.-Ground-Pine is viscid to the touch and has a resinous smell, with a bitter and somewhat styptic taste. The aqueous infusion is bitter and nauseous, and is rendered brown and opaque by sulphate of iron ; it appears to contain no acid nor ammoniacal salt. The aqueous extract is bitter and austere; the spirituous warm, sweetish, and bitter; hence alcohol would seem the better menstruum.

Medicinar. Properties and Uses.-The flowers and leaves of this plant have been held in much repute for their efficacy in gout and rheumatic affections of the joints $\uparrow$, hence it was called by the older botanists Iva arthritica, and formed an ingredient in the celebrated Portland-powder ${ }_{+}^{*}$. Its reputed tonic, stomachic, diuretic, and resolvent qualities have also recommended it in visceral obstructions, jaundice $\$$, and intermittent fevers, paralysis, hysteric and hypochrondriacal affections, obstructed

* "6 Chamæpitys Latine abiga vocatur, propter abortus, ob aliis thus terra cubitalibus ramis, flore pinus et odore."-Plin. Hist. lib. xxiv. c. 6.

+ Sennertus, Opera, t.v. \& vi. p. 177.-Claudin. Consult. xix. p. 49.Matthiol. in Dioscor. p. 669.

† See p. 154 .

\$ Fernel. Method. Med. lib. v. c. 7 . 
menses, and chlorosis. "It may also be given advantageously with the decoction of dandelion or agrimony, in diseases of the mesenteric glands or of the liver, and indeed in almost all those cases where mercury is so profusely given by modern practitioners."* It has been applied externally to ulcers and various tumours, and is said to have proved beneficial against cancer $t$.

A drachm of the powdered leaves has been directed to be taken in a glass of wine. The infusion is made with half an ounce of the dried plant to a pint of boiling water, of which a glassful may be administered twice or thrice a day: in this form it is usually combined with germander. The alcoholic extract in the dose of a scruple to a drachm, though seldom employed, appears to be one of the most efficient preparations of the plant.

* J. A. Waller, Brit. Dom. IIerb. p. 180.

† Morgagni de sedibus et caus. morb. Lisist. 39, § 35.-Peyrilhe Diss. de Cancro. 
XCII.

\section{SCOLOPODENDRIUM VULGARE.}

\section{Common Hart's-tongue.}

\section{Class XXIV. Cryptogamia.-Oóder I. Filices.}

Nat. Ord. Fiuces.

Gen. Char. Sori linear, transverse, on lateral nerves. Involucre double, occupying both sides of the sorus, opening by a longitudinal suture.

Spec. Char. Frond simple, cordate-ligulate, smooth beneath. Stipes scaly.

\section{S X NON Y M ES.}

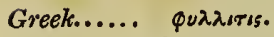

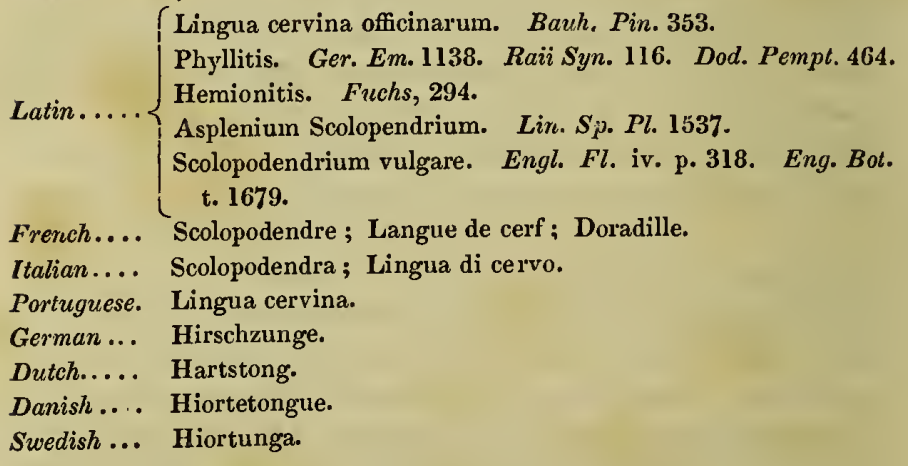

Description.-The root (rhizoma) is perennial, and furnished with numerous brown fibres. The leaves or fronds, which spring immediately from the root, are about a foot in length, and from one to two inches broad, somewhat coriaceous, light vivid green, smooth, plane, oblong, acute, cordate at the base, entire, undulated at the margin, and supported on petioles, which are clothed with mossy hairs or reddish șcales. The 
fructification is placed on the back of the leaves, on each side of the midrib, in oblique lines of a yellowish brown colour, called sori. The involucre is double, membranous, opening as it were longitudinally, and is turned back and concealed by the prominent capsules. Each capsule is one-celled, stalked, globose, and furnished with an elastic ring, which opens and ejects the sporules in the form of a fine powder. Plate 24, fig. 1, (a) part of the frond showing the sori ; $(b)$ a capsule magnified; $(c)$ the same open.

This elegant plant is common on moist shady banks, old walls, rocks, and at the mouths of wells and caverns, producing its fructification in August and September.

The generic name refers to the resemblance between the lines of fructification on the back of the frond and the insect called Scolopodendra. Hart's-tongue, or, as it is sometimes called, Hind's-tongue, is expressive of the shape of the frond.

Qualitres.-The plant has a faint, herbaceous, earthy smell, and a sweetish, sub-astringent taste; in drying it becomes slightly aromatic. It contains mucilage and a slight astringent principle, which, together with its slight aroma, it yields to water by infusion.

Medicinal Properties and Uses. - The ancient physicians considered Hart's-tongue a very valuable medicine, and freely invested it with astringent, resolutive, alterative, diuretic, and vulnerary properties. Galen, among others, recommends it in diarrhoea and dysentery, and it was deemed very useful to strengthen the viscera, restrain hemorrhages and alvine fluxes, expel gravel, and remove obstructions of the liver and spleen. It was also reckoned demulcent and pectoral, together with golden and common maidenhair, wall-rue, and common spleenwort, called the five capillary herbs. Simon Pauli mentions that the Germans used it with advantage, infused in beer, against enlargements of the spleen and hypochondriacal affections. Ray* recommends a drachm of the powdered leaves, in any convenient vehicle, for palpitations of the heart, and the hysterical affections and convulsions of women, but neither in these nor in the other diseases above enumerated is it much used in the present day.

- Hist. Plant. p. 135. 
XCIII.

\section{SISYMBRIUM OFFICINALE.}

Common Hedge-Mustard.

Class XV. Tetradynamia.-Order II. Siliquosa.

Nat. Ord. CRuctfere.

Gen. Char. Calyx patent, sometimes erect. Pod sessile, rounded or angular. Cotyledons plane, incumbent, sometimes oblique.

Spec. Char. Pods subulate, pubescent, close-pressed to the main stalk. Leaves runcinate, hairy. Stem hispid.

\section{SY NON Y MES.}

Greek .... spuбusev. Hippocrates.

(Erysimum vulgare. Bauh. Pin. 100, Tourn. Inst. 228.

Erysimum Dioscoridis Lobelii. Ger. Em. 254.

Eruca hírsuta siliquâ cauli adpressâ Erysimum dicta. Raii

Latin ..... Syn. 298.

Verbena fomina. Trag. 102.

Erysimum officinale. Lin. Sp. Pl. 922. Eng. Fl. iii. p. 196.

Eng. Bot. t. 735.

(Sisymbrium officinale. Dec. Syst. ii. p. 460.

French..... Velar; Velar des boutiques; Tortelle.

Italian.... Erisamo.

Spanish.... Erisimo; Jaramago.

German.... Wegsenf ; Hederich ; Wassernfhederich.

Dutch...... Steenraket.

Danish .... Vild Senep.

Swedish... Vœggkressa.

Polish .... Gorczyka polna.

Description. - The root is annual, tapering, and furnished with long fibres. The stem is erect, cylindrical, leafy, pubescent, with spreading branches, and rises from one to two feet in height. The leaves are alternate, petiolate, somewhat villous, 
scabrous beneath, deeply divided on both sides into two or three oblong, tooth-serrate lobes, the terminal one very large, roundish in the lower leaves, and oblong in the upper. The flowers are disposed in long terminal, spike-like racemes ; the pedicels very short and erect. The calyx is very small, composed of four oblong, concave, spreading, deciduous sepals. The four petals are very small, pale yellow, oblong, obtuse, unguiculate, entire. The stamens are six, tetradynamous, with subulate, erect filaments, and cordate anthers. The germen is linear, sessile, with a very short style, and a clavate, emarginate stigma. The silique, or pod, is erect, close-pressed to the main stem, roundish, subulate, with concave valves, and a membranous, bilocular dissepiment. The seeds are small, oblong, dingy yellow, and arranged in a single row. Plate 23, fig. 3, (a) radical leaf; (b) calyx; (c) petal ; (d) stamens.

This plant grows by way-sides and hedges among rubbish, in this country, and in nearly all Europe, flowering from June to August.

Sisymbrium was the name given by the Greeks to a species of mint, or some mint-like plant, while this species was called by them aquobuov. It has received the several provincial namcs of Bank-cresses, Scrambling Rocket, and Worm-seed.

Qualities and general Uses.-Hedge-Mustard has been used as an early pot-herb, but it has not much to recommend it. It is relished by sheep and goats, but horses, cows, and swine refuse it.

The herb is almost inodorous, with a sliglit acrid, warm flavour, resembling that of nasturtium. "The seeds are pungent, and their acrimony like that of mustard-seed is wholly extracted by watcr, and partially by alcohol, and strongly impregnates water in distillation."

Medicinal Properties and Uses.-Dioscorides * recommends the seeds of this plant taken in honey for diseases of the chest, purulent spittings, coughs, and jaundice, also as an external application to cancers, tumours, \&c. The herb has been most celebrated for its incisive and expectorant properties $\uparrow$; hence

* Mat. Med. lib. ii. cap. 188.

+ As a proof of the penetrating qualities of this plant, it has been as. serted that its peculiar flavour is perceived in the expectorated matter. 
the good effects attributed to it by Lobel * and others, in asthma and old coughs, as also in restoring the voice and removing hoarseness, for which purpose a syrup was prepared from it, which bore the name of Syrupus cantatoris, or singer's syrup. Rondeletius informs us that hoarseness occasioned by loud speaking was cured by this means in three days. "Ettmuller commends the seeds of Hedge-Mustard as an excellent medicine in suppression or difficulty of urine, in the dose of a drachm in powder, taken in a glass of white wine. It is not, however, in these affections, merely, that this plant may be employed with advantage; the same decided effects will be found to result from its use in accumulations of viscid pituitous matter in the stomach and bowels. In these cases an infusion in wine will be found peculiarly efficacious." $\dagger$

"Externally, this plant has been greatly celebrated as an application to occult cancer and indurated tumours, wherever situated." +

The juice may be made into a syrup with an equal quantity of honey or sugar : or a decoction of an ounce of the dried plant to a pint of water, may be sweetened in the same manner; in this form it has been recommended in ulcers of the mouth and throat. The roots and seed have been likewise employed. It must be kept in mind that preparations of this plant will not allow of an excessive degree of heat, or of its long continuance.

* Advers. nov. stirp. p. 69.

+ J. A. Waller, Brit. Dom. Herb. p. 183.

$\ddagger$ Ibid. l. c. 


\section{XCIV.}

\section{LAMIUM PURPUREUM.}

\section{Purple Hedge-Nettle, or Dead-Nettle.}

Class XIV. Didynamia.-Order I. Gymnospermia.

Gen. Char. Calyy campanulate, ten-ribbed, with fire nearly equal, aristate teetl. Corolla with the throat inflated; upper lip crect, entire, vaulted; lower lip patent, two-lobed, with one or two small reflexed teeth on each side at the base.

Spec. Char. Leaves eordate, obtuse, crenate-serrate, stalked, the uppermost crowded. Corolla elosed internally near the base with hairs.

S Y NON Y M E.

Lamium purpureum fœtidum, folio subrotundo sive Galeopsis Dioscoridis. Bauh. Pin. 230.

Latin ..... Lamium rubrum. Ger. Em. 703. Raii Syn. 240.

Urtica iners altera. Dod. 153.

Lamium purpureum. Lin. Sp. Pl. 809. Eng. Fl. ii. p. 91.

(Eng. Bot.t. 1933.

French.... Lamier pourprée; Ortie morte puante.

Italian.... Ortica morta.

Spanish.... Ortiga muerta.

German... Purpura Todtennessel.

Dutch..... Stinkende Doove Netelen.

Danish.... Doduelde.

Swedish.... Blind nesla.

Polish .... Pokozywa martwa.

Persian.... Kargasina.

Description.- - The root is anuual, slender, and fibrous. The stems are curved at the base and branched, then erect, naked, but thickly clothed with leaves at the summit, quadrangular, nearly smooth, and from six to nine inches in height. The leaves are cordate, obtuse, crenate-serrate, stalked, clothed with silky hairs, the uppermost with a purplish tinge. The 
flowers are disposed in crowded whorls at the top of the stem. The calyx is campanulate, ten-ribbed, with five awn-tipped teeth, often purplish. The corolla is ringent, purplish-red; the upper lip entire, arched; the lower lip patent, obcordate, twolobed, with one tooth on each side. The four stamens are didynamous, covered by the upper lip, with oblong anthers containing scarlet pollen. The germen is four-parted, with a filiform style, and a bifid spreading stigma. The fruit consists of four achenia, somewhat triangular, and convex on one side, seated in the persistent calyx. Plate 23, fig. 4, (a) corolla magnified; (b) anther; (c) calyx and pistil.

This very common plant flourishes under hedges, and by the borders of fields, especially in cultivated ground, flowering from May to September.

Various etymologies of the word Lamium are given by authors. Some

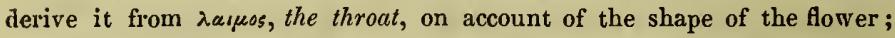
others from Lamia, a celebrated sea-monster or sorceress, whose visage it was supposed to emulate. It does not appear to be the Lamium of Pliny". This species is called provincially Red Archangel and Dee Nettle $\dagger$.

The plant is occasionally eaten by horses, goats, and sheep, but refused by cows. The young shoots are used as greens in some parts of Northern Europe.

Qualities.-- The plant diffuses a heavy and disagreeable odour, especially when bruised, and a nauseous, herbaceous, sub-astringent taste. Water extracts the whole of its sensible qualities.

Medical Properties and Uses.-The decoction of this plant has been chiefly commended in dysentery, also in pleurisy, inflammation of the kidneys, scrofula, and various diseases of the digestive organs. It was likewise esteemed useful as an external application to swellings, whether inflammatory or otherwise, also to foul, obstinate ulcers and wounds, and to burns and scalds when suppurating freely. The flowers $\ddagger$ of the White Dead-Nettle were considered almost a specific in fluor albus and other female disorders, but apparently with no just foundation. "In the inflammatory complaints above enumerated, the infusion of this plant, from its diuretic and sudorific properties, may be found useful as common drink ; and with a little pains it may be rendered sufficiently palatable." $\$$

* Hist. lib. xxii. c. 14.

+ The common White Dead-Nettle (Lamium album) is distinguished at once by its larger size, large white flowers, and rough acuminate leaves; besides wlich it is perennial.

$\ddagger$ Probably on account of their colour.

\$ J.A Waller, l.c. p. 185. 


\section{XCV.}

\section{HELLEBORUS NIGER.}

Black Hellebore, or Christmas Rose.

Class Xili. Polyandria.-Order III. Polygynia.

Nat. Ord. Ranunculace.e.

Gen. Char. Calyx of five persistent leaves. Petals eight to ten, small, tubular, two-lipped, nectariferous. Pericarps or follicles nearly erect, many-seeded.

Spec. Char. Radical leaves pedate, very smooth. Scape leafless, one or two flowered, bracteate.

S Y NONYMES.

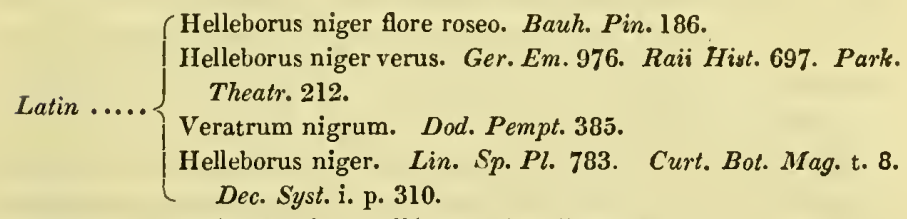

French.... Ellébore noir; Hellébore noir; Rose de Noël.

Italian... Elleboro nero.

Spanish... Eleboro negro; Yerba de Ballestero.

German... Schwarze Nieswurz; Schneerose; Christwurz.

Dutch .... Nieskruid; Maankruid; Herssenkruid.

Danish ... Short Nyserod.

Swedish.... Swart Prustort.

Bohemian. Ellebor cerny; Cerna cemerice.

Polish.... Czarna ciemerzyca.

Persian.... Kherbecksiya.

Hindoostanie Kali konthie.

Tamool.... Kadagaroganie.

Arabic.... Kherbekaswed.

Description.-The root consists of numerous thick, fleshy, descending fibres, proceeding from a large, transverse, knotted stock, externally nearly black, internally yellowish, shootıng up 
naked, thick, cylindrical scapes, four or five inches high, simple or bifurcate at the summit, with one or two terminal flowers subtended by two or three ovate bracteæ. The leaves expand with the scapes, or immediately after them; they are all radical, on long petioles, large, smooth, coriaceous, deep green, often spotted with reddish brown, pedate, with ovate, lanceolate, acute, serrated leaflets. The calyx consists of five large, roundish, obtuse, petaloid sepals, white, often tinged with rose-colour. The petals are very short, tubular, two-lipped, and nectariferous. The stamens are very numerous, with capillary filaments rather longer than the petals, and yellow roundish anthers. The germens, about six in number, are surmounted by as many subulate styles and roundish stigmas. The fruit consists of five or six coriaceous pericarps or follicles, which are ovate, compressed, mucronate laterally at the summit, arcuate at the border, opening by two valves, and containing many black shining seeds, disposed in a double series. Plate 24, fig. 2, (a) tubular petal (nectary of Linnæus); (b) pistils.

This plant is a native of Austria, the Apennines, Italy, and Greece, and is often cultivated in our gardens, flowering from December to February, whence it has obtained the appellation of Christmas Rose.

Black Hellebore was, for a long time, thought to be the $\varepsilon \lambda \lambda \varepsilon$ Bopos $\mu \varepsilon \lambda \alpha_{s}$ of Hippocrates, but the researches of modern botanists have proved that to be a distinct species, called by Willdenow Helleborus Orientalis. Their properties appear to be similar. This is the Melampodium of the old pharmacopœias, so called from Melampus, its discoverer*.

Qualrties.-The fibres of the root, which are the parts used medicinally, are about the thickness of a small quill, and when recent, are white or reddish internally, and covered with a pale brown epidermis. Their odour is nauseous; the taste bitter, somewhat acrid, and persistent. When chewed, they affect the tongue with a stupifying sensation; "or as if it had been a little burnt with eating or supping anything too hot." These qualities are impaired by keeping, and the epidermis becomes dark brown or nearly black.

The active matter appears to be of a volatile nature as it

* Bear's-foot, or Stinking Hellebore, has been already described. 
nearly all passes over in distillation with water, and the root may be almost deprived of its acrimony by successive decoctions. Alcohol also extracts its virtues, which would hence appear to depend on its resinous part. Feneulle and Capron* have discovered in it volatile oil, containing an acid, resin, an acrid̄ and bitter principle, mucus, \&c.

Poisonous Properties.-Black Hellebore, incautiously given, produces upon the animal system all the effects of a violent acrid poison, com. bined with some narcotic effects. Orfila found that two or three drachms of the root swallowed, killed a dog in a few hours; and a smaller quantity applied to a wound, produced the same effect more speedily. A decoction of an ounce of the root in water, caused death in eight hours. Schlabel relates that ten grains of the extract introduced into the windpipe, killed a rabbit in six minutes. The chief symptoms were violent efforts to vomit, giddiness, palsy of the hind legs, and insensibility.

The bulletins of the Medical Society of Emulation, mention two characteristic cases which arose from the ignorance of a quack doctor. Both persons, after taking a decoction of the root, were seized in forty-five minutes with vomiting, then with delirium, and afterwards with violent convulsions. One died in two hours and a half, the other in less than two hours. Morgagni has related a case which proved fatal in about sixteen hours, the leading symptoms of which were pain in the stomach and vomiting. The dose in this instance was only half a drachm of the extract. The morbid appearances were inflammation of the digestive canal, particularly in the great intestines. In a case, not fatal, related by Dr. Fahreuhorst, the symptoms were those of irritant poisoning generally, that is, burning pain in the stomach and throat, violent vomiting, to the extent of sixty times in the first two hours, cramps of the limbs, and cold sweats. The most material symptoms were at this time quickly subdued by sinapisms to the belly and anodyne demulcents given internally, and in four days the patient was well $\dagger$.

For the treatment of poisoning by this vegetable, see the articles Aconite, Bear's-foot, Colchicum, \&c. Orfila particularly recommends, to combat the stupefaction produced by Hellebore, infusions of coffee and camphor, in small doses frequently repeated, and if these be rejected a short time after they are swallowed, the same remedies should be employed in lavements and by friction. Demulcent drinks are also proper.

Medical Properties and Uses. - The root of Hellebore has been famous from time immemorial, as a remedy for insanity.

* Journal de Pharmacie, vii. p. 563.

+ Christison on Poisons, 3d Ed. p. 786. 
From its abundance in the isle of Anticyra, arose the proverb, " naviga ad Anticyras," take a voyage to Anticyras, which was the advice given by the ancients to those who had lost their reason*. Its repute in maniacal disorders appears to have arisen from its drastic purgative property of expelling the atra bilis, from whicli such maladies were invariably thought to originate; but they doubtless attributed some efficacy to the other medicines combined with it, and which tended to modify its violent action $\uparrow$. Its properties, however, vary much according to age; when recent, it is acrid and poisonous, and produces vesication of the skin; properly dried, it causes vomiting and purging, excites sneezing, and provokes the menstrual evacuation, \&c., but after being long kept, it retains merely a slight purgative virtue. To this difference in the sensible qualities of the root, are attributable the contradictory statements given of its action. The anti-maniacal powers of the Hellebore of the ancients, were again promulgated by Antonius Musa Brassavolus + , and more recently by Pechlinus $\oint$, Lorry \|, and Vogel $\Upsilon$. Its emmenagogue effects are strenuously insisted on by Mead**, and though it has often failed, as with

* Thus Horace, who considered avarice a mental disease, says :-

"Danda est ellebori multa pars maxima avaris :

Nescio an Anticyram ratio illis destinet omnem."

Sat. iii. lib. 2.

+ "They werevery careful to give it only to persons of robust constitutions, carefully directing that it should never be prescribed for children or old persons, or those of either sex whose habit of body was delicate. They prepared the patient for seven days previous to its exhibition, by a regulated diet, and frequent gentle aperient medicines. They had also several modes of preparing and correcting it, which are unknown to us, except that they selected only the fibres of the root, which they macerated a short time in water, and then separated the bark and dried it in the shade. This was administered (when powdered) in honey, or the pulp of raisins, to which they generally added some aromatic seeds. Ettmuller states, that an apple, particularly sweet, was chosen, and stuck full of the fibres of Hellebore root, then roasted under hot embers, the fibres were then withdrawn, and the apple eaten by the patient, which operated mildly, but effectually." Waller 1. c.

\# De Medicamentis catharticis.

§ De Purgant. p. 315.

If De Melanch. tom. ii. p. 343.

T) Diss. de insaniâ longâ, p. 21.

** Monita et precep. mel. p. 138. 
Home * and Pasta $\uparrow$, it sometimes proves beneficial in plethoric habits. It has also been found useful in hemorrhoids + , and obstinate quartan fevers $\S$, but more especially in dropsies $\|$ and some cutaneous diseases $\Pi$. Quincy recommends it in gout and rheumatism**, and it has also been given in epilepsy, paralysis, and against worms. Mr. Waller t $\uparrow$ has the following observations on the effect of Hellebore root as an errhine.

"In the depot for French prisoners of war at Norman Cross, in the year 1806, a peculiar disease, called Nyctalopia, was very prevalent among them. The symptoms which distinguish this disease are, that the patient becomes by degrees perfectly blind from the moment of sunset till the re-appearance of the bright luminary next morning. This disease affected a great number of the prisoners, who were obliged to be led about by their comrades immediately after sunset, and all of them at the same time were labouring under symptoms of extreme dyspepsia. After a variety of treatment ineffectually applied, the powder of black Hellebore was given them as a snuff: As they were most of them attached to the use of snuff, and had been for a long time deprived of it, they took the Hellebore with avidity, and generally recovered from their nyctalopia in the course of a very few days, and the dyspeptic symptoms were at the same time greatly relieved. There is no doubt that in many other affections of the head the same treatment would be found extremely efficacious, and is well worthy of trial in many chronic diseases of the eyes, particularly in the early stage of gutta serena."

Bacher's hydragogue tonic pills, a celcbrated remedy in dropsy, were composed of extract of black Hellebore ++ one ounce; myrrh, one ounce; powdered leaves of blessed thistle, ten scruples; to be made into pills of one grain, of which from ten to twenty were directed to be taken in the day.

* Clinic. Exper. \&c. p. 410.

+ Dissertaz. mediche sopra i mestrui delle Donne, p. 192.

† Schulzius, Mat. Med. p. 151 .

$\S$ Ilildanus Opera, p. 914.

II Friend observes, "According to Micenna, it provokes urine and the menses. I have made frequent trials of this medicine, and in dropsies I have seen most wonderful effects from it. Menzoar asserts that the flowers of the Water Lily are the best correctors of this root." Hist. vol. ii. p. 102, sqq. See also Gesner Libell. p. 121. Klein Sel. Med. p. 108.

T Aretæus (Opera ed Boerh. p. 136.) Celsus (ed. Lee, vol. i. p. 232.) Haller Collect. Disp. Pract. t. vi. p. 83. Hildanus Op. $l$. c.

* Pharm p. 183.

$+\dagger$ Brit. Dom. Herb. p. 189.

++ For the mode of preparing this extract, according to Bacher's method, see Jourdan's Pharmacopeé Universelle, tom. i. p. 491. 


\section{EXTRACT OF BLACK HELLEBORE ROOT*}

Take of Hellebore root, any quantity; having sliced and bruised it, pour upon it eight times its weight of boiling water, boil down to one half, express the liquor strongly, and strain it. Evaporate the decoction immediately to the consistence of thick honey, in a bath of boiling water, saturated with common salt.

To produce its cathartic effects, from ten to twenty grains are necessary; as an emmenagogue, from three to ten grains.

The dose of the root, as a purgative, is from ten to twenty grains, but as an alterative for attenuating viscid humours, promoting the uterine and urinary secretions, \&c., from two to three grains are sufficient. Of the decoction made with two drachms of the root to a pint of water, an ounce may be given every three or four hours. The tincture is thus prepared:-

\section{TINCTURE OF BLACK HELLEBORE.}

Take of Black Hellebore root, bruised ........ four ounces;

Proof spirit .................. two pints.

Macerate for fourteen days, and filter.

Recommended in uterine obstructions, and in gout.-Dose, a tea-spoonful twice a day.

Bisset asserts that an infusion of the leaves of Black Hellebore, in the dose of a drachm when fresh, or from fifteen to twenty-four grains in a dried state, forms an excellent febrifuge for children, persevered in for some days.

* Extractum Radicis Hellebori nigri. Pharm. Ed. 


\section{XCVI. \\ CONIUM MACULATUM.}

Common Hemlock.

Class V. Pentandria.-Order II. Digrnia.

Nat. Ord. Umbellifere.

Gen. Char. Calyx obsolete. Petals obcordate, with an inflexed point. Fruit ovate, laterally compressed. Carpels with five prominent waved, crenulate, equal ridges, of which the lateral ones are marginal. Channels with many striæ, desstitute of vittæ. Seed with a deep narrow furrow.-Involucres of three to five leaves, partial on one side.

Spec. Char. Stem branched, shining, spotted. Partial Involucre shorter than the umbellules.

S Y NONYMES.

Greek..... xwverov; xovssov.

Latin ... $\left\{\begin{array}{l}\text { Cicuta major. Bauh. Pin. } 160 . \text { Corl. fol. } 162 . \\ \text { Cicuta. Ger. Em. 1061. Raii Syn. 215. Fuchs, 399. Tragus, } \\ 474 . \text { Dod. Pempt. 458. } \\ \text { Cicuta vulgaris major. Park. Theatr. 933. } \\ \text { Conium maculatum. Lin. Sp. Pl. 349. Eng. Bot. t. 1191. } \\ \text { Coriandrum maculatum. Roth. A. germ. i. p. 130. }\end{array}\right.$

French... Cigue; Grande Cigue; Cigue ordinaire.

Italian.... Cicuta; Cicuta grande.

Spanish .... Cicuta; Cicuta manchada.

Portuguese. Ciguda.

German... Schierling; Erdschierling; Geflechter Schierling.

Dutch..... Scheerling; Dalle-Kervel.

Danish.... Scharntyde.

Swedish ... Sprœclig odœrt.

Bohomian.. Bolehlaw.

Polish..... Swinia wesz.

Russ...... Boligalow.

Description.-The root is biemnial, somewhat fusiform and branched, whitish, about the thickness of the little finger, from eight to ten inches long, and exudes, when young, a milky juice. 'The stem is erect, cylindrical, smooth, fistulous, striated, of a 
light shining green, spotted with purple or brown, and often covered with a blueish exudation, from three to five feet high, and much branched upwards. The lower leaves are very large, tripinnate, alternate, on long striated, concave petioles; the upper leaves are bipinnate, opposite the branches; the leaflets are pinnatifid, with lanceolate, obtuse, inciso-serrate segments of a shining green colour above, and paler beneath. The flowers are disposed in umbels of many, spreading radii, with a general involucre of about five leaves, and a partial one of three or four lanceolate leaves, placed externally on one side. The calyx is an obsolete margin. The petals are five, white, obcordate, with a short inflexed point, the outer slightly radiant. The stamens are five, with white capillary filaments, and roundish anthers, scarcely as long as the corolla. The germen is inferior ovate, green, crowned by the whitish disk, supporting two filiform reflexed styles, and obtuse stigmas. The fruit is brownish when ripe, ovate, slightly compressed laterally, dividing into two carpels, each of which is marked with five prominent undulated or crenate ridges, the channels much striated and without vittæ. The seed has a deep, narrow groove in front. Plate, 24, fig. 4, (a) entire flower magnified; (b) fruit.

This plant is not infrequent in waste places, by hedges and road sides, and near dunghills in this and other European countries. It flowers in June and July.

To discriminate between this plant and those with which it is sometimes confounded, it is sufficient to observe its shining spotted stem, fetid smell when bruised, the waved ridges of the fruit, the presence of involucres, of which the partial is on one side, and not near so long and pointed as in the Fool's Parsley (Athusa Cynapium); while it is nearly thrice the size of the latter. The Rough Chervil (Chorophyllum temulentum), having a spotted stem, is sometimes gathered for Hemlock, but it is distinguished by its swollen joints, together witl other obvious cliaracters.

The name is derived from rwvos, a top, "whose whirling motion resembles the giddiness produced in the human brain by a poisonous dose of the juice of this plant."

Common Hemlock is supposed to be the rovelov and cicuta of the ancients, as it corresponds in many particulars with the description given by Dioscorides and Pliny in their respective works; 


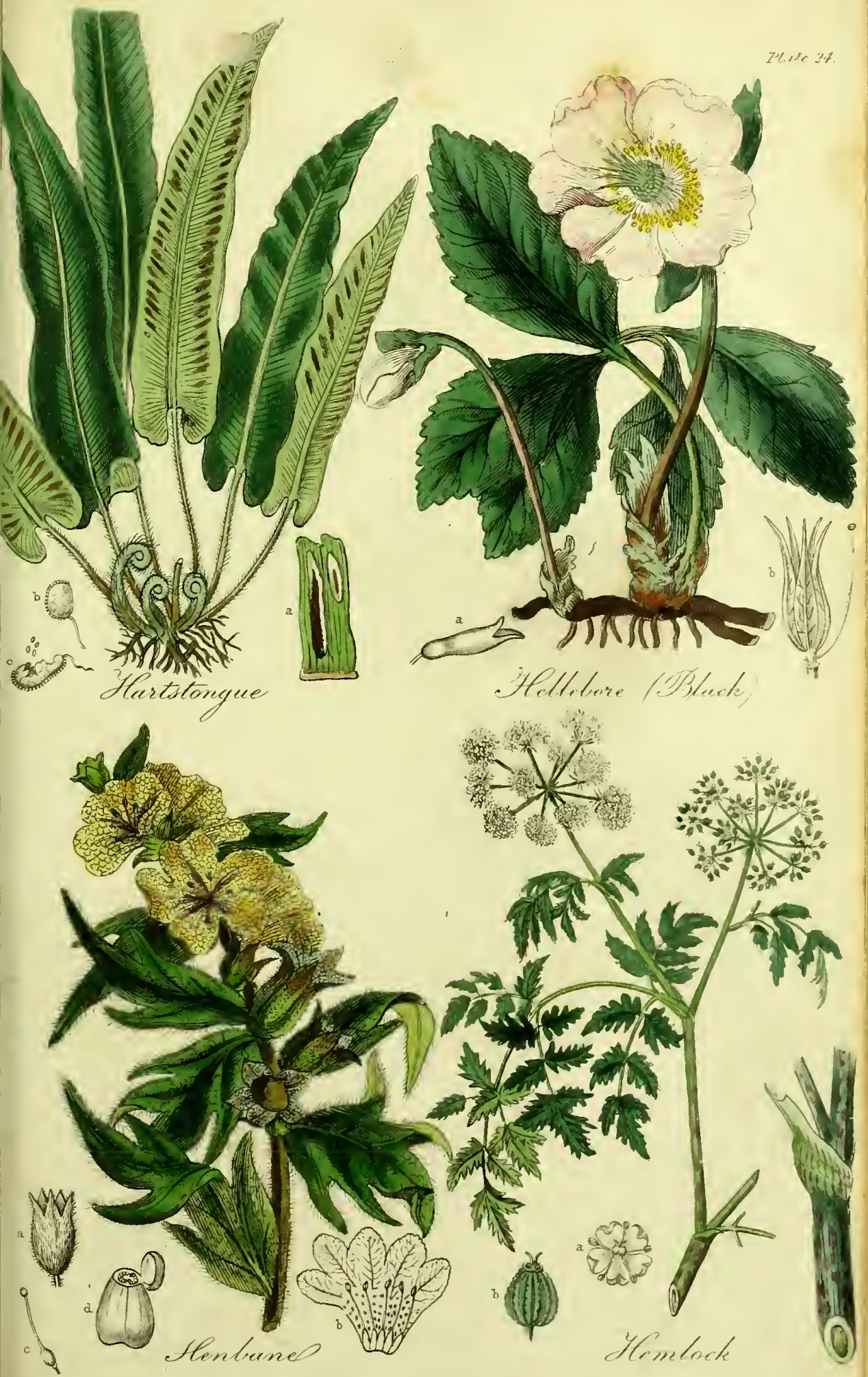



but so vague were the terms employed in those remote times, in delineating plants having so many common characters as the Umbelliferæ, that certainty on this point is unattainable. Indeed, as the term cicuta*, was also applier to that part of fistulous stems between the joints, so conium appears to have denoted more than one poisonous plant, which gives a colour to the opinion that the death-drinks of the Greeks were composed of the juices of several pernicious vegetables. Theophrastus $\uparrow$ relates, that a certain Thrasyas boasted of having discovered a potion compounded of the juice of conium, poppy, \&c. which would destroy life without pain ; and Elian tells us, that the Cean old men, when they had become useless to the state and tired of the infirmities of life, invited each other to a banquet, and having crowned themselves in festive mood, drank the Conium, and terminated their existence. The tranquillity maintained by Socrates + after swallowing the deadly potion decreed by the Areopagus, will scarcely accord with the known effects of Hemlock-juice, but that it was an ingredient in the fatal cup seems exceedingly probable, as the plant is very common in Greece, and a southern climate appears greatly to augment its energetic properties.

Qualities. - The recent plant has a disagreeable odour, resembling that of mice or cat's urine. The odour of the properly dried leaves $\S$ is strong, heavy, and narcotic, and the taste slightly bitter and narcotic. "The green leaves distilled impregnate the water in the receiver with an insupportably

* See Virgil, Ecl. ii. 1, 36, and v. 1. 85.-Persius Sat. iv. From cicuta ınost likely is derived kecks, denoting hollow stalks, and kecksies, the name for Hemlock and other plants with fistulous stems in many English counties, while in Wales the true Hemlock is called cegid, and Fool's-Parsley hemlock. Shakspeare distinguishes between them :-

\section{- - "Her fallow leas}

The darnel, hemlock, and rank fumitory,

Doth root upon.

- And nothing teems

But hateful docks, rough thistles, kecksies, burs,

Losing both beauty and utility."-IIenry $V$. act v. sc. 2.

$\dagger$ Lib. ix. c. 17 .

\# See the Phodon of Plato.

$\S$ For medical use, the leaves should be gathered just before the flowers expand, and the foot-stalks being rejected, dried nearly as directed for Foxglove, (see p. 334). Great care must be taken to kecp them from the action of air and light. 
bitter taste; this circumstance, and likewise the fact that the dried leaves become inert by age and exposure, render it probable that the chief medicinal efficacy resides in a volatile portion of the plant." Dr. Bigelow was unable to detect any volatile oil in this fluid; Geiger, however, has obtained a volatile oil possessing alkaloidal properties: this he has named conia, and he states that the dried leaves of Hemlock contain very little of it, and that even an extract of the fresh leaves contains very little, unless prepared with a gentle heat, yet speedily.

"The conia of Geiger is colourless, lighter than water, of a very powerful repulsive odour, and intensely acrid. It has a strong alkaline action on reddened litmus or turmeric. It is readily soluble in different acids, which it neutralizes, and is sparingly soluble in water, to which it imparts its power and taste." It is extremely poisonous.

Poisonous Properties.-Asses, sheep, and goats $\dagger$ eat the foliage of this plant without inconvenience, but it is reported to be noxious to kine; and dogs, wolves, rabbits, \&c., are very readily destroyed by it. Several birds, and thrushes in particular, feed on the fruit. Orfila found that an ounce of the extract of the leaves destroyed a dog in forty-five minutes, and twenty-eight grains, introduced through a vein, killed another in two minutes. Hence, he concludes, that the poison is carried into the blood, and acts upon the nervous system, and principally upon the brain. The most prominent symptoms were convulsions, paralysis, and insensibility.

Several cases are recorded of the deleterious effects of this plant on man. Dr. Watson $\ddagger$ mentions two cases in which it proved fatal. The sufferers were two Dutch soldiers, who had taken the leaves mixed with other herbs in broth; they were seized with giddiness, coma, convulsions, and death. Agasson $\S$ speaks of a man, who after taking a poisonous dose was affected

* See an excellent paper by Dr. Christison, in the London Med. Gazette, April 23 and 30, 1836.

\section{$\dagger$ " Pinguescere sæpe cicuta}

Barbigeras pecudes, homini quæ est acre venenum."-Luoretius.

† Philos. Transactions, vol. xliii. No. 473, p. 18 .

$\S$ In Orfila, Traité des Poisons, tom. ii. p. 307.-For other cases, see Corvisart's Journ. de Med. xxix. p. 107. Heins. Pharm. Rat. p. 570. Wolf in Comment. lit. Nor, 1746-69. Wepfer Cicut. p. 71-312. Ortila, $l$. $c$. 
with convulsions in the upper part of the body, while the inferior extremities were paralysed. In others he remarked furious delirium. On examination after death, the vessels of the head have been found much congested, and the blood remarkably fluid. Very different accounts are given of the properties of the roots of this plant. Ray* states, that three or four ounces of the root have been swallowed without any remarkable effect. Mr. Curtis speaks of a gentleman who had some of the large roots boiled, and found them as agreeable eating at dinner with meat, as carrots. On the other hand, Störck relates, that a drop or two of the milky juice applied to his tongue produced great pain and swelling of that organ, and for some time deprived him of the power of speech. Orfila gave two ounces of the juice, obtained from three pounds of the fresh root, to a dog, without any remarkable effects, while Wepfer relates the case of two monks, who became raving mad after eating the roots; and Vicat $\dagger$ mentions an instance of a vine-dresser and his wife, who mistook the roots for parsnips, and after partaking of them at supper, awoke in the night delirious, knocking themselves rudely against the walls of the room. The only way in which these discordant statements can be reconciled is by remembering the influence of climate. Fee informs us, that in Russia and the Crimea, Hemlock is inert and eatable, and that in the South of Europe, it is extremely poisonous. Soil and situation, and time of year, have also an influence on this plant, as on the Colchicum and others.

The treatment to be pursued in cases where this poison has been swallowed is nearly the same as directed under Fool'sparsley and Foxglove. The efficacy of vegetable acids, especially vinegar and lemon-juice + , in counteracting its deadly effects has been much insisted on; the poisonous substance having been first evacuated by the means already mentioned.

Medical Properties and Uses.-The root, leaves, herb, and especially the juice of Hemlock, were in former times considered softening, resolvent, anodyne, \&c., and were employed externally in procidentia ani, affections of the eyes, tumours, and against rheumatism, gout, erysipelas, and other exanthemata. Aretæus $\S$ attributes to it the peculiar power "frangere stimulum venereum," while Störck, Bergius $\|$, and other modern

* Phil. Trans. vol. xix. p. 634.

+ Histoire des plantes veneneuses de la Suisse, p. 274.

* There would thus appear to be a considerable analogy between Hemlock and the Ranunculus tribe of plants, as also in the volatility of their active principle; in both cases, repeated boiling in vinegar is said completely to dissipate the noxious quality. The Russian peasants, who are said to eat hemlock with impunity, take the precaution of boiling it in several waters.

\$ De Morb. Acut. lib. ii. c. 11.

\| Mat. Med. vol. i. p. 195. 
writers, assert that it has just the opposite quality. Avicenna* recommended a plaister of it for resolving tumours of the testes and female breast, and for preventing the coagulation of milk in the latter. It is chiefly, however, to the enterprising Baron Störck $\uparrow$ that we are indebted for a knowledge of the therapeutical effects of this important plant, and though some of his statements are doubtless exaggerated, many of them have been confirmed. He employed it in various indurations of the viscera, scirrhus, ulcers, tumours, cataract, gout, diseased bone, syphilis, leucorrhœa, jaundice, phthisis, \&c. Although British practitioners have not found it equal to the cure of cancer, it has proved very efficacious in allaying the pain and correcting the fetid discharge from cancerous sores; also in chronic rheumatism, glandular swellings, and various fixed and periodical pains. Dr. Bigelow $\ddagger$ speaks highly of its effects in jaundice, and in some cases of tic doloureux.

As a sedative it is a good substitute for, or adjunct to, opium, relieving the irritability of the system in cancer, and procuring sleep in many nervous diseases. In hooping-cough, combined with ipecacuanha, it is a valuable remedy; likewise, in the protracted coughs which supervene to pleurisy and other affections of the chest; and in phtlisis, either alone or combined with ipecacuanha or sulphate of zinc, it will allay the irritability of the lungs, and mitigate the sufferings of the patient. Like other powerful medicines, it acts very differently on some individuals, in consequence of idiosyncrasy, and instead of affording relief, produces dimness of the eyes, giddiness, singing in the ears, head-ache, and even convulsions.

The powder of the leaves properly dried is the best form of administering Hemlock, until some mode of attaining uniformity in the preparation of the extract be discovered. The commencing dose is two or three grains, gradually increased until slight vertigo forbids us to proceed. "Hufeland recommends the fresh expressed juice, from twelve to sixty drops for a dose." $\S$

* Canon. Med., ed. F. Paulinus, tom. i. lib. ii. cap. 669. See also Plinii Hist. lib. xxvi. c. 22. Lemery, in Ehrhart Diss. de Cicuta, § 11.

$\uparrow$ Libellus de Cicuta, 1 \& 2.-Supplementum.-Libellus quo contin. exper. passim.

† American Med. Botany, vol. i. pt. ii. p. 120 .

§ Thomson's Dispensatory, p. 302. 
The British colleges order an extract, a tincture, an ointment, and a cataplasm.

\section{EXTRACT OF HEMLOCK * \\ Take of fresh Hemlock leaves....... a pound.}

Bruise them in a stone mortar, having sprinkled a little water upon them, then express the juice, and without suffering the dregs to subside evaporate it to a proper consistence.

The extract is apt to vary very much in strength; by commencing, however, with a small dose, its power is soon ascertained. Four or five grains for an adult, and one grain for a child, three or four times a day, gradually increased as the patient can bear it. It may be given either in the form of pill or in solution. The extract from the seeds is said to be more powerfully narcotic than the preceding.

$$
\text { TINCTURE OF HEMLOCK } \uparrow \text {. }
$$

Take of dried leaves of Hemlock........ one ounce;

Cardamom seeds bruised .......half an ounce;

Proof spirit ................ sixteen ounces.

Digest for seven days and filter through paper.

Dose from six to twenty drops.

Externally, the powcler mixed with a bread-and-water poultice, is the usual method of applying it, but the fresh herb is preferable when it can be obtained.

- Extractum Conii.-Pharm. Lond.

† Tinctura Conii.-Pharm. Ed. and Dubl. 


\section{XCVII. \\ EUPATORIUM CANNABINUM.}

Common Hemp-Agrimony.

\section{Class XIX. Syngenesia.-Order I. Polygamia ÆQUALIS.}

Nat. Ord. Conposite.

Gen. Char. Involucre imbricated, oblong. Florets few. Receptacle naked. Pappus rough.

Spec. Char. Leaves opposite, subpetiolate, three or five partite; segments lanceolate, deeply serrate.

\section{S, Y N O N Y M E.}

Latin...... $\left\{\begin{array}{l}\text { Eupatorium cannabinum mas. Ger. Em. } 711 . \\ \text { Hepatorium vulgare. Dod. Pempt. 28. } \\ \text { Eupatorium adulterinum. Fuchs. 266. c. 101. } \\ \text { Eupatorium cannabinum. Bauh. Pin. 320. Raii Syn. } \\ \text { 179. Lin. Sp. Pl. 1173. Eng. Fl. iii. p. 400. Eng. } \\ \text { Bot.t. } 428 .\end{array}\right.$ French..... $\begin{aligned} & \text { Eupatoire; Eupatoire commun; Eupatoire a feuilles de } \\ & \text { chanvre; Eupatoire d'Avicenne; Herbe de Sainte Cune- } \\ & \text { gonde. }\end{aligned}$

Ital. \& Span. . Eupatorio.

German.... Wasserhanf; Wasserdost; Kunigundenkraut.

Dutch...... Boelkens-kruid ; Koninginne-kruid.

Danish..... Kunigundsurt.

Swedish..... Floks.

Polish ....... Sandriek.

Description.-The root is perennial, oblique, moderately thick, and furnished with many whitish fibres. The stem is erect, cylindrical, tomentose, green, tinged with purple, full of white pith, branched, and from three to four feet in height. The leaves are shortly petiolate, opposite, divided into three or 
five lanceolate lobes; the midclle lobe longest, of an ashcoloured green, slightily pubescent on the upper surface. 'T'he flowers are very numerous, and thickly crowded in terminal corymbs. The involucre is composed of oblong, obtuse, imbricated scales, coloured at the summit ; for the most part forming calyces, which enclose about five salient florets. The corollas are uniform, tubular, perfect, with a regular five-lobed limb, of a pale reddish-purple colour. The filaments are capillary, very short, with the anthers united into a tube. The germen is oblong, small, with a filiform style, longer than the corolla, and deeply cleft; stigmas downy, spreading. The fruit is oblong, angular, crowned by the sessile, pilose pappus. The receptacle is small and naked. Plate 25, fig. 1, (a) group of five flowers detached from the corymb, $(b)$ floret, isolated, (c) fruit.

This plant flourishes on the banks of rivers and in watery places, flowering in July and August.

The name Eupatorium, according to Pliny*, was given in honour of Eupator Mithridates, King of Pontus, who first discovered its medicinal properties. It is uncertain whether this plant was known to the ancients; it appears not to be the Eupatorium of the Greeks nor of Avicenna.

Qualities and general Uses. - The leaves of this plant, with the addition of logwood boiled in a solution of green vitriol, yield a good black colour. Dambourney obtained a yellow dye by making a decoction of the whole plant. It is not eaten by any animal except the goat.

Hemp-Ayrimony has a strong odour, somewhat resembling that of umbelliferous plants, such as wild parsnep. Every part of the plant, and especially the root, has a bitter, pungent, and aromatic taste; but the leaves lave most bitterness. It contains a small quantity of resin, united with an abundant, acrid, bitter mucilage, soluble in boiling water, while the resinous part is soluble in alcohol. In distillation with water, it yields a volatile oil.

Medical Properties and Uses.-Gesner $\uparrow$ found by experiment that the root of this plant infused in wine produced voniting and copious evacuations both by stool and urinc,

* Hist. lit. xxv, c. 6.

+ Epist. ful. lxiii. el exxi. 
Schroder recommends the herb in cachexia, coughs, and suppression of the menses. Tournefort* speaks highly of its effects in obstructions of the viscera, intermittent fevers, and dropsy. Boerhaave $\uparrow$ calls it rusticorum panacea, and states that the turf-diggers in Holland use it with great benefit in jaundice, scurvy, foul ulcers, and those swellings of the feet to which they are much exposed. It has also been applied externally in the form of a cataplasm to various tumours, particularly hydrocele, and to ulcers ; and the expressed juice united with vinegar and common salt has been a favourite application to some cutaneous diseases.

In the internal complaints mentioned above, Geoffroy recommends a handful of the leaves and tops to be boiled in two pints of water or whey; or the expressed juice in the dose of two or three ounces, either alone or combined with that of fumitory. The dried leaves may be used in the form of tea. An ounce of the root boiled in half a pint of water is useful in dropsies, frequently taken; a larger dose causes sickness. The extract may be given alone or united with sugar, to the amount of one or two drachms and more.

- Hist. des Plantes, tom. i. p. 329.

† Hist. Pl. Rom., pt. i. p. 175. 


\section{Class V. Pentandria.-Order I. Monogynia.}

Nat. Ord. Solanere.

Gen. Char. Calyx tubular, five-cleft. Corolla funnelshaped, oblique. Stigma capitate. Capsule two-celled, opcning by a lid.

Spec. Char. Radical leaves pimnatifid, sinuate; upper amplexicaul. Flowers nearly sessilc.

\section{SY NONYMES.}

Greck......... vooxvaros. Dioscorides.

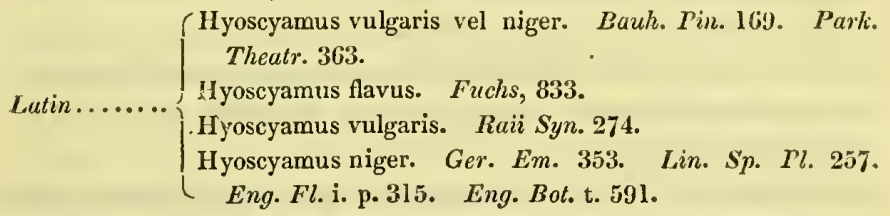

French..... Jusquiame ; Hanebane.

Italian....... Giusquiamo.

Spanish....... Beleno.

Portuguese.... Yosciamo; Meimendro.

German...... Bilsenkraut; Schwarze Bilsenkraut.

Duıch....... Zwart Bilzenkruid; Dolkruid.

Danish ..... Fandensnosser; Sodbonne; Bulmeurt.

Swedish ..... Bolmcrt.

Bokemian .... Blyn.

Polish...... Bielun; Szaley; Lulek.

Russ. ...... Belena.

Arabic ..... Buzirulbunj ; Urmanikun; Sikran.

Description.-The root is annual, thick, fusiform, wrinkled, somewhat branched, brown externally, and whitish within. The stem is erect, cylindrical, branched, covered with clammy woolly hairs, and rises from one to two feet in height. The leaves are large, alternate, amplexicaul, soft, woolly, clammy, ovate-lanceolate, acute, sinuated, and irregularly lobed. The 
flowers are nearly sessile, and terminate the stem and branches in a long leafy spike, all turned in one direction, and somewhat pendulous. The calyx is tubular, five-cleft, veined, persistent. The corolla is funnel-shaped, divided into five obtuse lobes; the tube nearly white, purplish at the orifice, and the limb pale yellow or straw colour, elegantly reticulated with brownish purple veins. The five filaments are subulate, downy at the base, and tipped with cordate purple anthers. The germen is roundish, surmounted by a filiform purple style, as long as the stamens, terminated by a capitate stigma. The capsule is ovate, with a furrow on eacl side, two-celled, opening by a lid, and firmly inclosed in the calyx. The seeds are numerous, obovate, curved, brown, hard, and covered with minute depressions. Plate 24, fig. 3, (a) calyx, (b) corolla, opened, (c) pistil, (d) capsule detached from the calyx.

This plant occurs in waste places, especially in chalky soil, near towns and villages. - It is found in most parts of the civilized world. It flowers in July.

The generic name is compounded of vs, vos, a hog, and ruauos, $a$ bean, the fruit being eaten with impunity by hogs. The common English name refers to the fatal effects of the plant upon poultry.

Qualities.-The lurid appearance, and heavy odour of this plant, together with its clamminess to the touch, seem to indicate its noxious qualities. The odour sonewhat resembles that of the black currant, but it is stronger and more disagreeable. The herb is almost insipid to the taste, and the root sweetish. The leaves when burnt have somewhat the odour of tobacco, and they sparkle with a deflagration like nitre. Geiger and Hesse * have lately discovered in this plant a substance which they consider the pure active principle, and have named it hyoscyamine. It has the form of fine silky crystals, is inodorous, very acrid, soluble in alcohol and ether, and but sparingly so in water, while the hyoscyamine of Brandes is oleaginous, and diffuses a fetid odour. An empyreumatic oil of a very energetic nature, is also obtained from it. "The virtues of Henbane are completely extracted by dilute alcohol. The watery infusion is of a pale yellow colour and insipid, 
and has the narcotic odour of the plant. It is not altered by the acids. The alkalies change it to a deep greenish yellow, which, on the addition of an acid, disappears, and a brownish flocculent precipitate is produced. Sulphate of iron strikes with it a black colour, and a dark precipitate is slowly formed; a copious white precipitate is produced by acetate of lead, and black ones by nitrate of silver. Thence Henbane appears to contain resin, mucus, extractive, a peculiar alkaline salt, and gallic acid."*

Poisonous Properties.-Goats, sheep, and swine are said to eat this plant with impunity; and Renard + states, that horse-dealers are accustomed to mix the seeds with oats in order to fatten their horses. It is injurious to stags, and fatal to most birds, especially the gallinaceous tribe, also to fishes, and to nearly all insects $\underset{+}{+}$. The smell is said to drive away rats. "According to the experiments of Orfila, the juice of an extract procured from the leaves, stems, and especially the root, produces in animals a state of sopor, much purer than that caused by opium. It is most active when injected into the jugular vein, less so when applied to the cellular tissue, and still less when introduced into the stomach. Except occasional paralysis of the heart, indicated by florid blood in its left cavity, no morbid appearance is to be found in the dead body. Six drachms of the pharmaceutic extract of the leaves killed a dog in two hours and a quarter, when swallowed; and three drachms killed another in four hours through a wound in the back. Its action appears to be exerted through the medium of the blood-vessels, and is purely narcotic." $\$$

The whole plant appears to be poisonous to man; Sir J. Smith, however, and Professor Martyn assert that they have swallowed the seeds without inconvenience, while several other writers mention instances of their dangerous and even fatal effects $\|$. Perhaps the oil contained in the seeds when taken in

* Thomson's Dispensatory, p. 392.

+ Journal de Medicine, tom, xxviii. p. 243.

¥ Except a species of Cimex, or bug, and Chrysomcla, or beetle, which feed upon it.

§ Christison, 1. c. from Orfila.

If Hippocrates (de Morb. Mul. lib. i. ed. Frs. p. 629) states that they cause delirium. Sir Hans Sloane (Phil. Trans. vol. xxxviii. p. 99) adduces an instance of four children who eat the seeds, mistaking the capsules for filberts. The symptoms were great thirst, giddiness, dimness of sight, 
small quantities modifies their narcotic effects, and thus the "bane and antidote" may accompany each other : they certainly contain a poisonous principle, since they yield by analysis more hyoscyamine than the leaves*. Even the emanations of the plant have produced unpleasant effects, and the roots $\dot{\dagger}$, eaten by mistake for those of parsnep, have often caused death.

Choquet $\%$ describes the effects of Henbane on two soldiers who eat the young shoots dressed with olive oil. They soon experienced a sensation as if the ground were reeling beneath them; they had a stupid appearance and their limbs were swollen; subsequently the eyes became haggard, the pupil excessively dilated, and the sight dull and fixed; the pulse was small and intermittent, the breathing difficult, the jaw locked, and the mouth distorted by the risus sardonicus; there was also that union of delirium and coma termed typhomania: the limbs were cold and palsied, the arms agitated by convulsive movements, and to all these alarming symptoms was added carpologia. By the exhibition of emetics and purgative lavements, one of the men was soon relieved, the other continued delirious until the next day, but by means of frictions, copious doses of vinegar, and strong purgatives, he ultimately recovered.

Although Henbane ranks as a pure narcotic, the treatment recommended when speaking of Foxglove, Hemlock, \&c., will equally apply to this plant; viz., the administration of emetics, and sub. sequently purgatives and vegetable acids.

Medical Properties and Uses.-Henbane was well known to the ancients, as appears from the writings of Dioscorides $\$$, but little use appears to have been made of it except as an ravings, and profound sleep.-See also the case mentioned by Haller, (Hist. Stirp. Helv. n. 580, ) of a fellow student of his who narrowly escaped with his life.-Helmont, Ort. imag. morbos. p. 306. - Essays and Observations, phys. and lit. vol. ii. p. 243.

- Has the immaturity of the seeds any influence upon their qualities? Poppy seeds when unripe are said to be hurtful, but when quite mature they are bland and nutritive.

+ The effect of season and vegetation on the energy of the root seems to be very great. Orfila found that the juice of three pounds of the root collected in April, when the plant had hardly begun to shoot, killed a dog in two days; while a decoction of an ounce and a half, obtained on the last day of June, when the plant was in full vigour, proved fatal in two hours and a half.

† Journal de Leroux et Corvisart, Avril 1813, p. 355. For cases of poisoning by the roots see Wepfer de Cicuta, \&c. p. 230.-Phil. 'Trans. vol. xl. p. 446. - Orfila, Traité des Poisons, tom. ii. p. 189.-Wilmer on thePois. Veg. of Great Britain, p. 3.

\$ Mat. Med. lib. ir. c. 69. 
occasional topic*. Celsus $\downarrow$ recommends the leaves to be made into a collyrium with yolk of egg, and the seeds as an ingredient in pills for procuring sleep. Plater \$ considered the seeds useful in hæmorrhoids and hæmoptysis, and Boyle highly commended an electuary composed of equal quantitics of the seeds of Henbane and white poppy, with conserve of red roses, as a remedy in hæmorrhages. To Störck $\S$, however, almost exclusively belongs the merit of discovering the true character and value of this plant. He administered the extract of the leaves in convulsions, epilepsy, palpitations of the heart, and inveterate headache, likewise in mania, melancholy, and hæmoptysis with the best effects. In the hands of later practitioners it has not proved equally successful in a!l these affections, but it forms an excellent substitute for opium in those cases where the latter produces sickness and head-ache, or costiveness, as it tends rather to relax the bowels and promote diaphoresis. Although in general it induces pleasant sleep, in some constitutions it occasions head-ache, nausea, feverishness, colic pains, and a copious flow of urine $\|$.

It has been found very serviceable in various spasmodic affections, hysteria, pyrosis or water-brash, gout, rheumatism, and in gall-stones when they occasion spasms of the duct In phthisis it allays the cough and general irritability of the system, and in colica pictonum it proves very useful combined' with purgatives, such as colocynth, the griping effect of which it

* It has been famous, however, for the purposes to which it has been abused by desiyning persons, such as fortune-tellers, conjurors, cunningmen, \&c. From the leaves was prepared the sorcerer's ointment, and from the root the celebrated anodyne necklaces "to be hung about children's necks, to prevent fits and cause an easy breeding of the teeth." $A$ very different quality is attributed to the seeds of Henbane by a German writer in the Ephemerides Germ. vii., viii. decur. 3, p. 106 : he states that the fumes of the seeds proceeding from a stove caused a violent quarrel between a man and his wife who had previously lived in the utmost harmony.

+ De Medicina, lib. v. c. 25, lib. vi. c. 6.

+ Prax. MIed. p. 635 .

$\S$ Lib. de Stramonio, Hyoscyamo, \&c. p. 26, sq.

II "In a full dose the delusions it presented to the mind in the first instance were the most delightful that can be conceived. The scenes before the eyes were of a most enchanting description, and every sense was ravished with the utmost excess of pleasure. These scenes, however, were as transient as they were delightful: in a few hours the senses were as much annoyed as they had before been gratified, and the utmost irritability of mind succeeded to the most delightful tranquillity."-Waller, $l . c$. 
greatly diminishes. It has been employed with decided advantage in mania in combination with camphor*, and is very efficacious in allaying the irritation occasioned by red sand in the kidneys $\uparrow$. As an external application its sedative effects are very conspicuous. A cataplasm of the leaves has been found useful in assuaging gouty and rheumatic pains, and various inflammatory swellings. Tournefort ${ }_{+}^{+}$recommends a decoction of the same in milk to dissipate coagulated milk in the female breast. Fomentations with a decoction of the leaves are also stated to be beneficial in sprains, luxations, and bruises, scrofulous and cancerous ulcers, hæmorrhoids, \&c. Hufeland recommends the leaves and marsh-mallow flowers boiled in milk, with the addition of a few grains of acetate of lead, as a topical application in scrofulous ophthalmia. An infusion of this plant dropped into the eye causes dilatation of the pupil like belladonna, and being milder in its action, it is sometimes employed prior to the operation for cataract. The smoke of the dried leaves, or of the seeds received through a funnel, is a popular remedy for tooth-ache.

The extract $\S$, prepared in the same way as that of hemlock, is the usual form of administering this remedy. The dose is from three to five grains, gradually increased to one scruple, made into pills. In chronic rheumatism it is usefully combined with blue pill and compound powder of ipecacuanha.

$$
\text { TiNCtURe OF HeNBane } \| \text {. }
$$

Take of dried leaves of Henbane.. four ounces;

Proof spirit ............ two pints.

Macerate for fourteen days and filter.

This is a valuable narcotic, in the dose of a drachm at bedtime, to be taken in a saline draught. In diarrhœa, a few drops of laudanum should be added to correct its laxative effects.

The depurated juice of the plant and the powdered leaves are now rarely administered; the latter were given in the dose of two to ten grains. The leaves, mixed with lard and simmered over a slow fire, are made into an ointment, and in the same manner with different resins into a plaister, to be applied to tumours and other painful affections.

* Thomson's Dispensatory, p. $393 . \quad+$ Brande's Pharmacy, p. 125.

$\mp$ Plantes de Paris, tom i. p. 342.

§ Extractum Hyoscyami.-Pharm. Lond. Dubl. Ed.

II Tinctura Hyoscyami,-Pharm. Lond. Ed, Dubl. 


\section{XerX.}

\section{PARIS QUADRIFOLIA.}

Common Herb-Paris.

\section{Class VIII. Octandria.—Order III. Tetragynia.}

Nat. Ord. Smilacex.

Gen. Chin. Calyx of four sepals. Petals four. Anthers attached to the middle of the filament. Berry fourcelled; each cell with several seeds in two rows.

Spec. Char. Leaves ovate, usually four in a whorl.

\section{S X NON Y M E.}

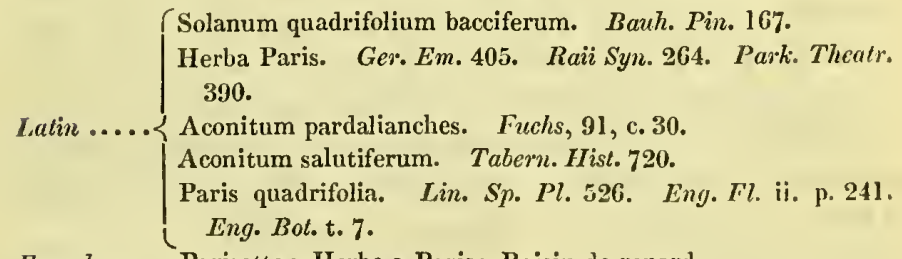

French.... Parisette; Herbe a Paris; Raisin de renard.

Italian.... Uva di volpe.

Spanish.... Uva de zorro.

Portuguese. Parisetta.

German.... Einbeere; Wolfsbeere; Fuchstraube.

Dutch .... Wolfsbezie.

Danish.... Elbœr.

Swedish ... Trallbœr.

Polish .... Wronie oko.

Description.-The root (rhizoma) is perennial, creeping, fleshy, somewhat jointed, and furnished with a few fibres. The stem is erect, simple, cylindrical, smooth, naked helow, obsoletely striated, and about a foot in height. The leaves are gene- 
rally four in a whorl, towards the summit of the stem, ovate, acute, entire, three-nerved, of a deep dull green colour, sessile, and spreading horizontally. The peduncle is terminal, erect, one-flowered, and shorter than the leaves. The calyx consists of four, pale green, linear-lanceolate, acute, reflexed, persistent sepals. The corolla is composed of four linear-subulate, yellowish-green, reflexed petals, rather shorter than the calyx. The stamens, eight in number, have subulate filaments, with long, linear, two-celled, yellowish antlers attached to their middle. The germen is superior, roundish, dark purple, supporting four spreading styles, shorter than the stamens, with simple stigmas, which are downy above. The fruit is a globose berry, obsoletely four-sided, purplish-black, shining, about the size of a small cherry, with four cells, each containing several ovate globose seeds arranged in two rows. Plate 25, fig. 2, (a) the flower seen in front with its sepals, petals, and stamens; $(b)$ the pistil; $(c)$ the berry; $(d)$ a vertical section of the same to sliew the seeds; $(e)$ seed.

This singular plant is by no means common, but it generally occurs in profusion if at all, preferring moist and shady dells in woods and coppices, where it flowers from May to the end of June. It is a native of Europe, from Spain to Lapland.

The generic name is said to be derived from par, paris, equal, in allusion to the regularity of the parts of the flower and fruit; the number four prevailing. In addition to the term Herb-Paris it has also been called One-Berry and True-Love *.

Qualities and general Uses.-Bohmer asserts that the dried leaves of this plant impart a fine yellow colour to yarn or linen cloth previously soaked in alum water. The foliage is eaten by goats and sheep, but refused by horses, cows, and swine. The berries are poisonous to poultry.

"The recent root has a narcotic odour resembling smoke," + and rather a nauseous taste, which becomes more agreeable or drying. The fresh herb has also a narcutic smell and an herbaceous, subglutinous, sweetish taste, re. sembling that of an unripe pea. The berries are similar in taste and smell to the leaves.

Herb-Paris ranks with the acrid narcotics, and if taken into the system

* " Herbe-Paris hath foure leaues directly set one against another in manner of a Burgundian crosse or true-loue knot; for which cause among the antients it hath been called Herbe True-loue."-'Gerard.

+ Bergius. 
may produce effects similar to colchicum, foxglove, \&c. The berries are said to have proved noxious to children.

Medical Properties and Uses.-This plant was recommended by Tragus, Camerarius, and other of the old writers, as an excellent remedy in the form of cataplasm to inflammatory tumours, cancers, pestilential buboes, \&c. The berries were used for the same purpose and were likewise esteemed beneficial in diseases of the eyes *. Gesner $\uparrow$, however, made some experiments which placed the virtues of the plant in a new light, but which do not prove it superior to others of the same class. He gave ten grains of nux vomica to two dogs; one of them died in four hours, the other, which was made to swallow half a drachm of Herb-Paris, escaped unhurt, being seized with

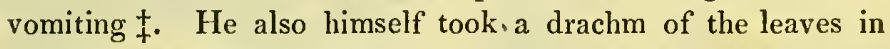
wine, which caused profuse perspiration and dryness of the throat. Hence probably the character of the plant as an alexipharmic and remedy in the plague, in which it was frequently prescribed. Linnæus $\S$ recommends the root in doses of thirty to forty grains as an emetic in lieu of ipecacuanha. Coste and Willemet || confirm this assertion, and state that its operation is rendered more certain by the addition of a little emetic tartar. Bergius If gave a scruple of the dried leaves every night to a child labouring under hooping-cough; by this means the bowels were gently opened, and tranquil sleep followed. He speaks of its efficacy in other convulsive diseases, and had known it commended in mania.

The precise value of this plant as a therapcutical agent, is not however, well understood, and its propcrties need to be further explored. It has been compared to opium, while its botanical affinities place it very near meadow-saffron (Colchicum autumnale).

* By the peculiar induction of those who believed in signatures; - the dark purple berry having some resemblance to the pupil of the eye.

+ Epist. med. p. 53.

\# A similar experiment with arsenic and corrosive sublimate is mentioned by Lobel.

§ Flora Lapponica, ed. Smith, p. 124.

II Essais sur quelques plantes indigenes, p. 12.

qi Mat. MIel. tom. i. p. 313. 


\section{GERANIUM ROBERTIANUMr}

\section{Herb-Robert, or Fetid Crane's-Bill.}

\section{Class XVI. Monadelphia.-Order II. Decandria.}

Nat. Ord. Geraniacee.

Gen. Char. Caly $x$ of five sepals. Corolla of five regular petals. Glands five, nectariferous, at the base of the longer filaments. Fruit beaked, separating into five one-seeded capsules, each with a long smooth awn.

Spec. Char. Peduncles two-flowered. Leaves three or five-parted; leaflets pinnatifid, with mucronate segments. Petals entire, twice as long as the angular, hairy calyx. Capsules wrinkled.

\section{S Y NONYM E S.}

Greek........ repaviov.

Latin ...... $\left\{\begin{array}{l}\text { Geranium robertianum primum. Bauh. Pin. } 319 . \\ \text { Gratia dei, vel Geranion. Tragus, } 108 . \\ \text { Geranium robertianum. Ger. Em. 939. Raii Syn. 358. } \\ \text { Lin. Sp. Pl. 955. Eng. Fl. } \text { iri. p. 235. } \\ \text { 1486. }\end{array}\right.$

French ..... Geranion; Bec-de-grue robertin; Herbe à Robert.

Italian ...... Geranio Robertiano.

Spanish....... Geranio hediondo ; Pico de grulla.

German..... \{ $\begin{aligned} & \text { Storchschnabel; Stinkender storchschnabel; Ruprechst- } \\ & \text { kraut. }\end{aligned}$ Dutch...... Robbert's-kruid; Roode Oijevaarsbek.

Description. - The root is annual, slender, branched, fibrous, and of a yellowish-white colour. The stems are about a foot high, trailing, and much branched at the base, hairy, jointed, and of a 

Foddish hue, brittle and shining. The leaves are opposite, petiolate, three and five-parted, with trifid, pinnatifid leaflets, the segments shortly mucronate, tinged with red, shining, and sprinkled with whitish hairs; the stipulæ short, acute, enlarged at the base. The flowers are axillary, two together on a bifid peduncle, longer than the petioles. The calyx is hairy, striated, angular, ventricose, composed of five lanceolate, mucronate sepals, of a reddish hue. The corolla is of a bright roseate purple colour, streaked with white lines, and consists of five regular, entire, oblong, spreading petals, twice as long as the calyx. The stamens are ten, the filaments united at the base, five alternately shorter, with elliptical two-celled anthers; at the base of the longer filaments are five nectariferous glands. The germen is roundish, five-lobed, with a subulate style, and five cylindrical, recurved stigmas. The capsules or carpels, five in number, are reticulated and wrinkled in their upper half, and furnished with long naked awns, separating in a spiral manner from the base to the apex of the common axis; each containing an oblong, smooth seed. Plate 25, fig. 3, (a) calyx, stamens, and pistils ; (b) petal; (c) tube of the stamens opened; $(d)$ the five capsules separating from the common axis; $(e)$ one of the capsules or carpels.

This plant is frequent in woods, thickets, and waste ground, on old walls, and among stones, and the debris of rocks. A small variety is common by the sea-side, and it is sometimes found with white flowers. It flowers from the end of April to October.

The name of the genus, the yepavior of the Greeks, is derived from yeparos, a crane, in allusion to the shape of the fruit, which has some resemblance to the beak of that bird. This specics was named Herb-Robert from its coming into flower about St. Robert's day *, the 29th of April.

There are about thirteen native species of Geranium, of which the one here figured is perhaps the most common. The cultivated Geraniums form a distinct genus, Pelargonium.

Qualities and generat Uses.-Herb-Robert has heen employed in some parts of the continent, in the process of tanning, and a yellow dye, it

- Si. Robert flourished in the eleventh ceutury; he was the founder of the Cistercians. 
is said, may be obtained from the leaves. According to Linnæus it is eatell by horses and goats, and occasionally by cows, but is refused by sheep and swine. He also states that the bruised herb drives away bugs. It has been much used by farmers as a remedy for the staling of blood and the bloody flux in cattle.

The recent plant has a strong peculiar odour, resembling that of the deadnettle or wood-strawberry, but more powerful and less pleasant; and a slightly bitter, saline, and austere taste. Its astringency is manifested by the dark colour and precipitate produced in the decoction by sulphate of iron. The astringent principle is taken up both by water and alcohol, and remains undiminished in the respective extracts. The odoriferous matter is separated by distillation with water, but no essential oil has been obtained.

Medicar Properties and Uses.-This plant was formerly much celebrated for its vulnerary powers, and as an efficacious remedy in hæmorrhages*, alvine fluxes, and in calculous and gravelly complaints $\downarrow$, jaundice + , and scrofula ; and Haller asserts that it has proved beneficial in intermittent fevers. Externally it has been commended in various affections; in epilepsy $\S$, tumours of the female breast, cancer $\|$, œedematous swellings of the feet $\pi$, and scald-head.

The plant reduced to powder has been given in the dose of a drachm in wine; a preferable form would be the infusion or decoction which might be given in diseases where a slight astringent is indicated. Externally it has been recommended in the form of cataplasm, and the powder is said to have arrested bleeding at the nose, when introduced into the nasal fossæ, and to act as a useful detergent when sprinkled on wounds and ulcers.

Further experiments are necessary to ascertain the medicinal value or inertness of this plant.

- Stocker, prax. aur. lib. i. c. 17, p. 119.-Hinderer, Diss. de Geranio Robertiano.--Theodorus Tabernaem. Krauterbuch, vol. i. p. 129.

+ Theod. Tabern. 1. c.

$\mp$ A. Murray, Diss. de methodo luis venereæ curandæ, p. 30 .

$\S$ Theod. Tabern. lib. cit. p. 127.-Tissot Avis au peuple, p. 354.

If Sennertus, lib. iv. P. 3. c. 7. Hildanus, Obs. et Curat. Cent. 6, obs. 75. Simon Pauli Quad. Bot. p. 73.

If Chomel, Usuelles, tom. ii. p. 301. 
PEUCEDANUM OFFICINALE.

Sea Hog's-Fennel, or Sea Sulphur-zort.

\section{Class V. Pentandria.-Order II. Digynia. Nat. Ord. UMbellifere.}

Gen. Char. Calyx of five teeth. Petals obovate, with an inflexed point. Fruit mueh compressed dorsally, girt with a broad thin margin. Carpels with nearly equidistant ridges; the three intermediate ones filiform; the two lateral ones eontiguous to, or eombined with, the margin. Channels with single vittæ. Seed flat on its inner face.-General involucre various; partial of many leaves.

Spec. Char. Leares five times tripartite, with linear, acute, flaeeid segments. Involucre of about three setaeeous, deeiduous leaves.

\section{SYNONYMES.}

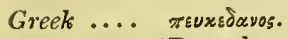

(Peucedanum Germanicum. Bauh. Pin. 149.

Peucedanum. Ger. Em. 1054. Raii Syr. 206.

Latin...... Peucedanum vulgare. Park Theatr. 880.

Peucedanus. Fuchs, 572, c. 228.

Peucedanum officinale. Lin. Sp. Pl. 353. Eng. Fl. ii. p. 99. Eng. Bot. t. 1767. Dec. Prod. iv. p. 177.

French..... Peucédan; Fenouil de porc; Queue de pourceau.

Italian.... Peucedano; Finnoccio porcino.

Spanish.... Peucedano; Servato.

German... Haarstrang; Scwefelwurzel Haarstrang ; Saufenchel.

Dutch.:... Hairstreng; Varkens-Venkel.

Danish .... Svinekenkel.

S'wedish... Svinfinkel.

Polish .... Wieprzniec.

Description.-The root is perennial, fusiform, thick, long, of a dark colour externally, whitish within, and containing a fetid resinous juice. The stem is erect, cylindrical, striated, branched, smooth, leafy, tough, and about three feet in height. The leaves are long, rigid, and divided five or six times successively into three leaflets; the segments linear, nearly flat, aente, flaccid, and entire. The flowers are disposed in large, many-rayed, concave umbels, with a general and partial involucre, of a few setaceous, deciduous leaves. The calyx consists of a five-toothed, inflexed margin. The five petals are obovate, equal, with in acute inflexel point and of a yellow colour. The five stamens have capillary filaments, longer than the 
petals, tipped with roundish anthers. The germen is oblong, supporting two small recurved styles, terminated by obtuse emarginate stigmas. The fruit is broadly elliptical, tawny. (See Gen. Char.) Plate 25, Fig. 4, (a) entire flower magnified; $(b)$ calyx, germen, and styles; $(c)$ the fruit, somewhat magnified ; $(d)$ the two carpels separating at maturity.

This plant, a native of the south and middle of Europe, has been long naturalized in England, though rare, being only found in salt marshes and ditches in the south-eastern parts of the island, flowering from July to September.

The genus takes its name from the $\pi \varepsilon u r \varepsilon \delta a v o v$ of Dioscorides and the other Greek writers, which is supposed to be identical with this plant; so called from $\pi \varepsilon v \pi n$, a pine-tree, in allusion to the bituminous odour of the root. This odour has also been compared to that of sulphur, which, together with the yellow colour of the juice, has suggested the name sulphurwort. It has also been called horestrong, horestrange, and harestrong, corruptions apparently of the German haarstrang.

Qualrties.-The fresh root has a strong, fetid, sulphureous smell, and a heavy, unctuous, subacrid, bitterish taste. The roots wounded in spring exude a large quantity of yellow juice, which soon concretes into a hard gum-resin, having all the sensible properties of the plant.

Medical Properties and Uses. - The roo: of this plant was a favourite remedy with Hippocrates and his immediate 5uccessors *, and was recommended in coughs, phlegmatic obstructions of the lings, nephritic pains, flatulencies, and difficult labours, and externally in hemicrania, ulcers, and painful tumours. By modern writers it is almost totally disregarded, and is seldom or never used in the present day ; nevertheless, it is by no means inert, and might probally be substituted occasionally for the gum-resins ammoniacum and galbanum. Bergius, indeed, designates the root as anti.hysteric, diuretic, and emmenagogue; and Delius $\dagger$ mentions a case of suppressed menses.which yielded to it, as well as an obstinate scorbutic complaint, in which the persevering use of the decoction and vinous extract proved beneficial.

The vinous extract in the dose of twenty to thirty grains has been much lauded in hysteric affections and hypochondriasis. The inspissated juice or the extract has also been made into a syrup, either alone or with the addition of liquorice-root and leaves of coltsfoot, as a remedy for asthmas and inveterate coughs. " Externally it is recommended for the cure of certain cutaneous eruptions of the leprous kind, for which purpose a decoction of it should be used for a bath, and in this manuer there is little doubt that it would prove efficacious." $\ddagger$

* Vide Galen de Simpl. lib. viii._-J. Bauhin Hist. tom. iii. p. 376.

+ Diss. de Peucedano germanico, p. 32, sq.

+J. A. Waller, Brit. Dom. Herbal, p. 141.

END OF VOL. 1 .

G. Woodfall, Printer, angel Court, Skinner Street, London. 




Boang
Buo.C 1
$1845-B$
Voe 1


